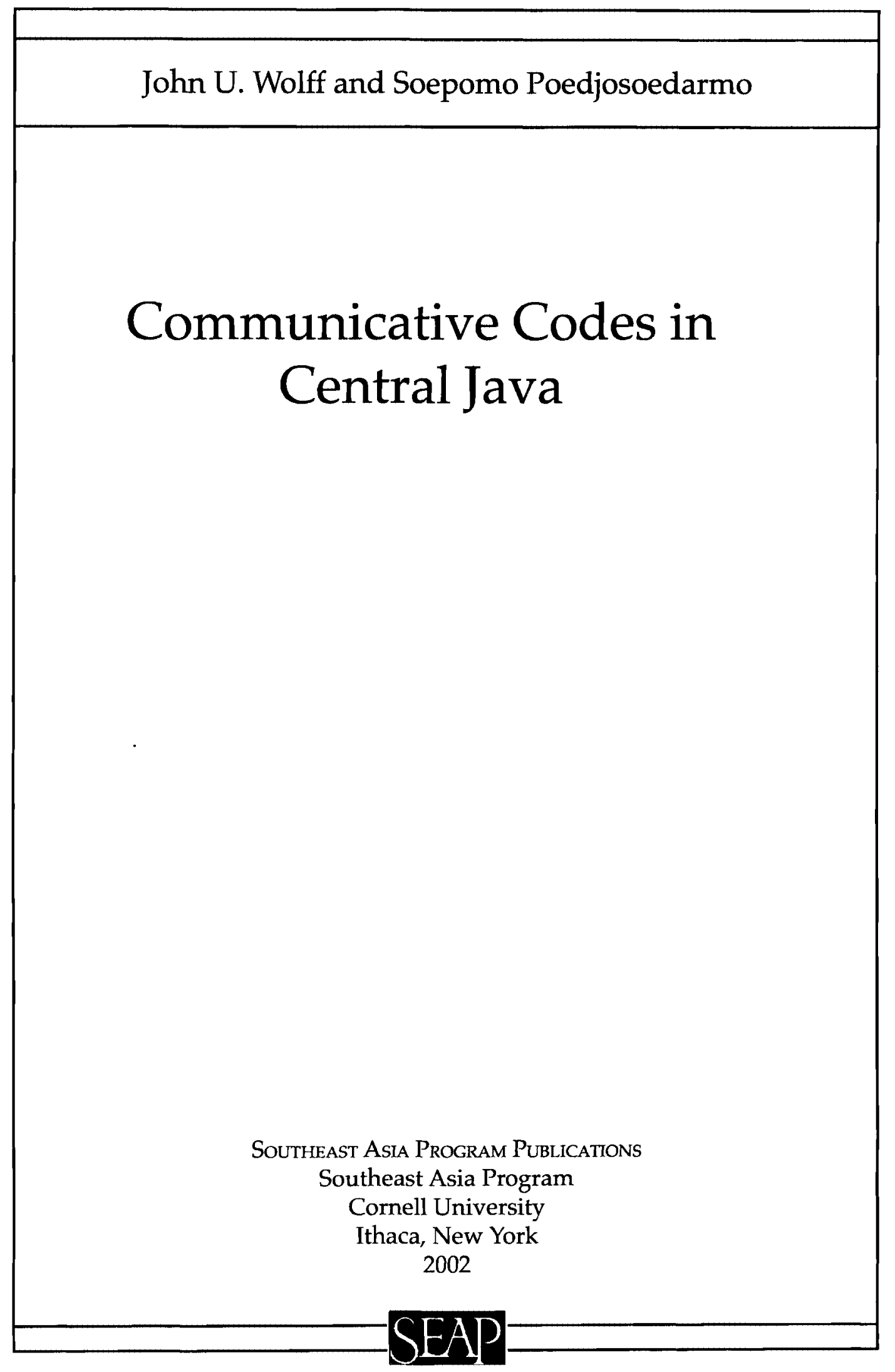


Editorial Board

Benedict R. O'G Anderson

Tamara Loos

Stanley O'Connor

K. W. Taylor

Andrew Willford

Cornell Southeast Asia Program Publications

640 Stewart Avenue, Ithaca, NY 14850-3857

Data Papers Series, Number 116

(C) 1982 Cornell Southeast Asia Program. Second printing, 2002.

All rights reserved. Except for brief quotations in a review, no part of this book may be reproduced or utilized in any form or by any means, electronic or mechanical, including photocopying and recording, or by any information storage or retrieval system, without permission in writing from the Cornell Southeast Asia Program.

Printed in the United States of America

ISBN 0-87727-116-X 
THE CORNELL UNIVERSITY SOUTHEAST ASIA PROGRAM

The Southeast Asia Program was organized at Cornell University in the Department of Far Eastern Studies in 1950. It is a teaching and research program of interdisciplinary studies in the humanities, social sciences, and some natural sciences. It deals with Southeast Asia as a region, and with the individual countries of the area: Brunei, Burma, Indonesia, Kampuchea, Laos, Malaysia, the Philippines, Singapore, Thailand and Vietnam.

The activities of the Program are carried on both at Corne11 and in Southeast Asia. They include an undergraduate and graduate curriculum at Cornell which provides instruction by specialists in Southeast Asian cultural history and present-day affairs and offers intensive training in each of the major languages of the area. The Program sponsors group research projects on Thailand, on Indonesia, on the Philippines, and on linguistic studies of the languages of the area. At the same time, individual staff and students of the Program have done field research in every Southeast Asian country.

A list of publications relating to Southeast Asia which may be obtained on prepaid order directly from the Program is given at the end of this volume. Information on Program staff, fellowships, requirements for degrees, and current course offerings is obtainable from the Director, Southeast Asia Program, 120 Uris Ha11, Cornel1 University, Ithaca, New York 14853. 


\section{Communicative Codes in Central Java}


FOREWORD

This study is a report of fieldwork done over a period of sixteen months 1973-1974 in the area of Yogyakarta, Central Java, Indonesia. Unfortunately, due to the pressures of our duties and commitments, this report had to wait until now for publication. Our aim is to provide a grammar of code choice in the speech community of Central Java, basing ourselves upon an empirical examination of texts collected with a cassette recorder and transcribed exactly. That is, we aim to provide a taxonomic description of the speech varieties in daily use in Central Java (the Javanese speech levels, Indonesian, and variations of register--formal, colloquial, intimate, literary styles) in terms of their social meanings--what the choice of one or another code does in terms of human interaction, or in terms of putting into effect the values which motivate the society.

Our recordings of spontaneous and unedited conversations turned up data of a totally surprising sort, far different in form from anything anyone had previously described and far different in function than anyone had previously thought. We were by no means able to exhaust the incredible richness of the data. We leave virtually unexplored the vast resources which these data supply for studying how members of the speech community structure their discourse and the implications thereof, especially for a comparative study of the two major subgroups of the community, the speakers of Chinese descent and those of Javanese descent.

A glance at the texts given in the appendix will serve to show the rich possibilities. For students and scholars who are interested in making a further examination of sociolinguistics in Central Java, we are prepared to make available the original texts, recordings and notes.

This work was undertaken with the help of a grant from the Social Sciences Research Council, which provided a stipend for both of us and research funds to hire assistants and purchase supplies and equipment. We express our thanks to the SSRC for this help coupled with apologies for the inordinate delay in submitting the final version. We also owe a debt of gratitude to the numerous assistants who worked on the project, making the recordings, transcribing the cassettes, and consulting with us in helping us understand what was happening in the course of the conversations which were recorded. We list here our principal assistant-informants: Supadmo, a teacher in SMP XIV in Yogyakarta, Suyitno, of the Local Industry Office in Wonosari, F. B. Alip, Suharso, Eddy Nugroho, Danan Widharsana, students in IKIP Sanata Dharma at the time of the study, Sumardiati and Suwartini, students in IKIP Negeri, Yogyakarta, at the time, and Imam Maliki, a student in the Universitas Islam Indonesia at the time. Thanks are also due to our two capable and careful typists: Mrs. S. Soebandi of Malang, Indonesia, for typing the drafts and making innumerable comments and corrections. and Mrs. Roberta Ludgate for doing an incredibly rapid and careful job on a difficult and messy manuscript. Finally, we owe particular thanks to 
Mrs. Audrey Kahin for a magnificent job of editorial correction. Her innumerable stylistic improvements, and penetrating comments on every single obscurity, improved this manuscript immensely. Without all this help, we could not have undertalren this study. However, we take final responsibility for errors which this work might contain.

\section{Yogyakarta}

August 1981

SP

JW 
TABLE OF CONTENTS

1. INTRODUCTION $\ldots \ldots \ldots \ldots \ldots \ldots \ldots \ldots \ldots \ldots \ldots \ldots \ldots \ldots \ldots \ldots \ldots \ldots \ldots \ldots$

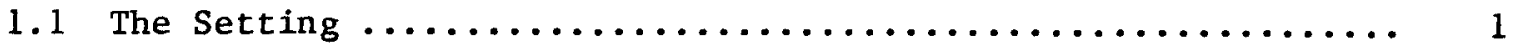

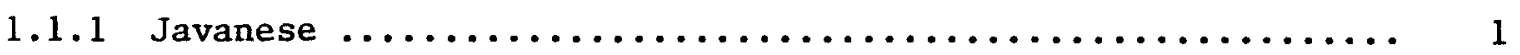

1.1 .2 The Javanese Speech Community $\ldots \ldots \ldots \ldots \ldots \ldots \ldots \ldots \ldots \ldots$

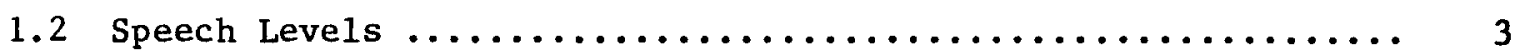

1.2.1 Meaning Relationship of the Level and Honorific Vocabularies 7

1.2 .2 On the Origin of the Speech Levels $\ldots \ldots \ldots \ldots \ldots \ldots \ldots \ldots \ldots .8$

1.2.3 Comparison of This Analysis with Other Analyses ......... 9

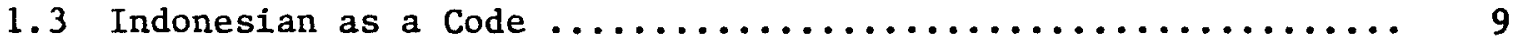

1.4 The Methods and Aims of This Study $\ldots \ldots \ldots \ldots \ldots \ldots \ldots \ldots \ldots$

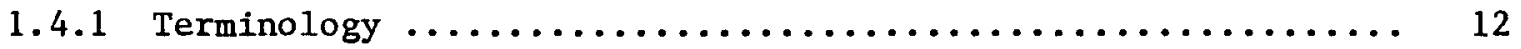

2. THE FUNCTION OF THE SPEECH LEVELS $\ldots \ldots \ldots \ldots \ldots \ldots \ldots \ldots \ldots \ldots \ldots \ldots \ldots . . \ldots$

2.1 Javanese Values and the Meaning of the Speech Levels ........ 14

2.1.1 Comparison of Javanese Speech Level Meaning with the T-V Variation of European Languages .................... 19

2.1 .2 The Use of the Speech Levels .................... 20

2.1.2.1 Cases of Unbalanced Exchanges .................. 25

2.1.2.2 Balanced Relations ........................ 26

2.1.2.3 Personality Differences Which Affect Speech Level Choice - 27

2.2 Forma1 Features Which Define Each of the Speech Levels ...... 28

2.2.1 Determination of the Speech Levels .................. 29

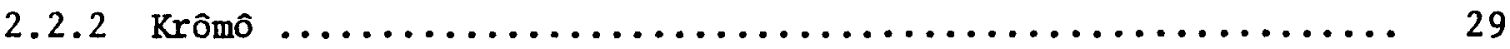

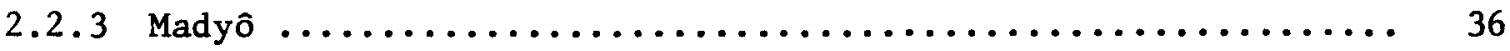

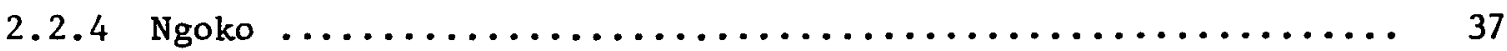

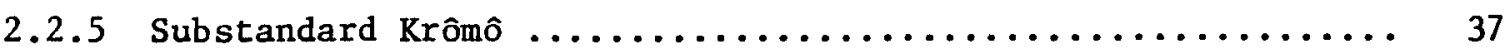

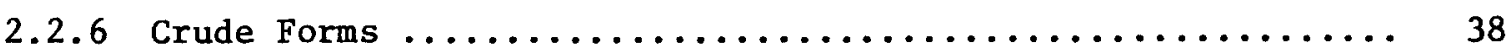

2.2.7 Low-Class Speech as Reflected in the Use of the Speech

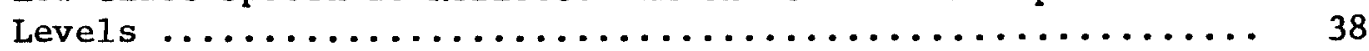

2.2.8 Honorifics (Krômô Inggil and Krồô Andhap) ........... 39

2.3 Terms of Address and Titles and Their Relation to the Speech

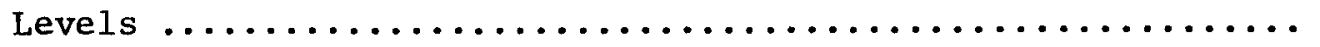




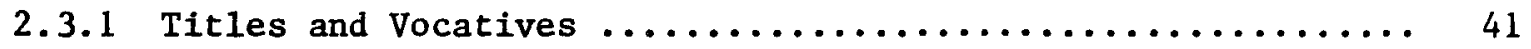

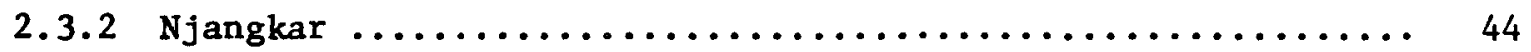

2.3.3 Terms for 'You' $\ldots \ldots \ldots \ldots \ldots \ldots \ldots \ldots \ldots \ldots \ldots \ldots \ldots \ldots \ldots . \ldots \ldots$

2.3.3.1 The Avoidance Pattern ....................... 44

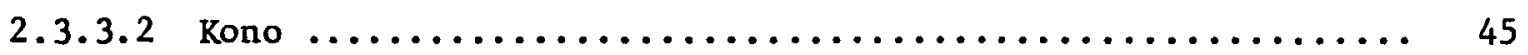

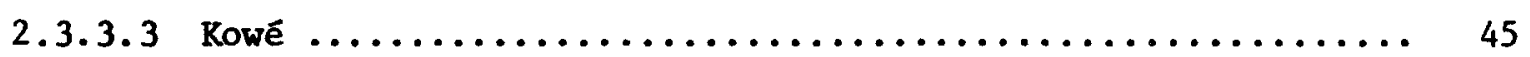

2.3.3.4 A Title or a Title plus a Name as a Term of Address ..... 45

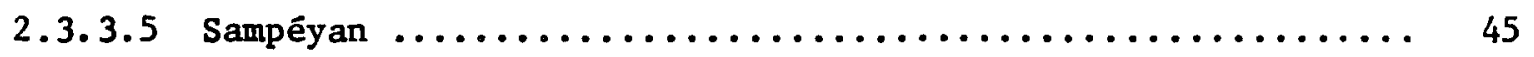

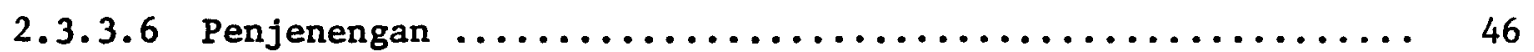

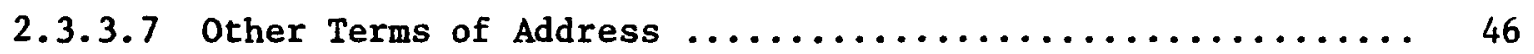

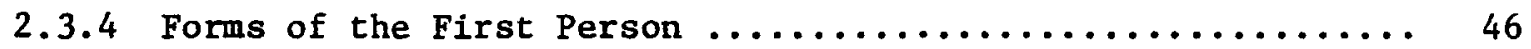

2.4 Speech Level and Honorifics in Children's Speech ......... 47

3. THE FUNCTION OF INDONESIAN $\ldots \ldots \ldots \ldots \ldots \ldots \ldots \ldots \ldots \ldots \ldots \ldots \ldots \ldots \ldots$

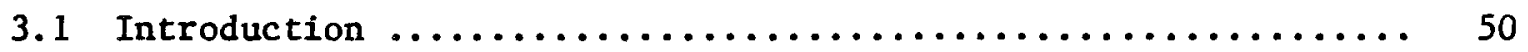

3.1.1 Forms of Indonesian Used by Javanese Speakers to Other Javanese Speakers ............................ 50

3.2 Subject Matters and Settings in Which Indonesian is Chosen ... 52

3.3 Indonesian as a Method of Giving Importance to the Utterance - 54

3.4 Indonesian as a Neutral speech Level ................ 57

3.4.1 Indonesian as a Means for Resolving Conflicts in Code Choice 57

3.4.2 Indonesian as a Device to Correct a Wrong Code Choice ..... 59

3.4.3 Indonesian as a Device for Addressing Several Interlocutors 60

3.4.4 Indonesian as a Device for Distinguishing Asides from the Principal Narration .......................... 61

3.4.5 Choice of Indonesian in Order to Adjust to a Change of Status or to Speech Level Usage Which Has Changed in Recent Times ............................... 61

3.4.6 Shift to Indonesian to Avoid Honorifics or High Speech .... 62 3.5 0ther Factors which Lead to a Choice of Indonesian ........ 63

3.5.1 Indonesian as a Device to Cover up Incompetence in Javanese 63

3.5 .2 Indonesian for Euphemism ...................... 63

3.5.3 Indonesian as a Method of Disclosing Personal Feelings ..... 64

3.5.4 Indonesian Forms Which are on Their Way to Being Adopted as

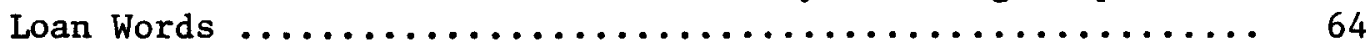

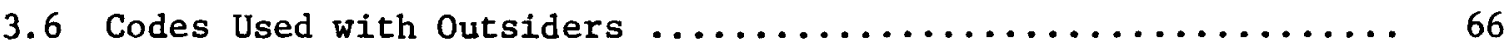

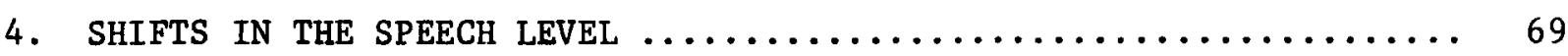

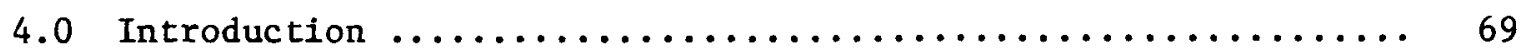

4.1 Quoting others .............................. 69 


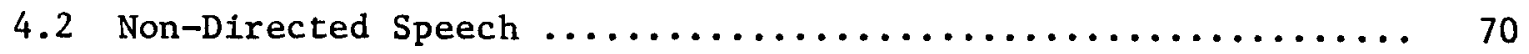

4.2.1 Functions of Non-Directed Speech as Thinking Aloud ....... 72

4.2.2 Non-Directed Speech as a Device for Indirection ......... 74

4.2.3 Non-Directed Speech as a Way of Creating an Intimate

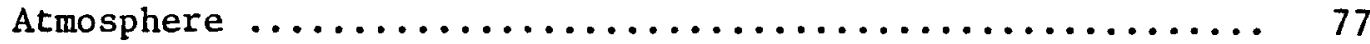

4.2 .4 Non-Directed Speech Aimed at a Group $\ldots \ldots \ldots \ldots \ldots \ldots \ldots \ldots$

4.3 Switches in Level Occasioned by Tone, Subject Matter, or Changed Perception of the Interlocutor ............... 79

4.3.1 Drops in Leve1 Occasioned by the Subject Matter or Tone .... 79

4.3.2 Raising of Speech Level for Rhetorical Effect .......... 80

4.3.3 Switch in Speech Level Reflecting a Change in the Interlocutor's Perception of the Speaker ............... 81

4.3.4 Shift in Speech Level Because of Uncertainty in Relative Status ................................... 83

4.4 Shifts in Level from Lack of Control ................... 84

4.4.1 Drop in Level from Lack of Control over the Speech Levels .. 84

4.4.2 Shift in Speech Level under the Influence of Immediately

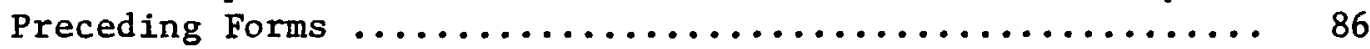

4.4.3 Shift in Speech Levels Caused by a Temporary Loss of Self-Control .............................. 87

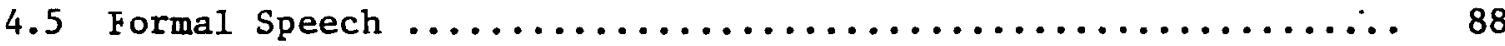

4.6 The Pragmatics of Stylistic Variation ................ 89

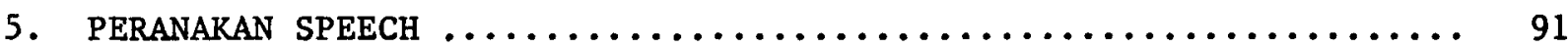

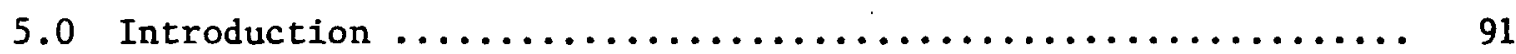

5.0 .1 Levels and Indonesian in Peranakan Speech ............ 92

5.1 Formal Features of Peranakan Speech ................. 92

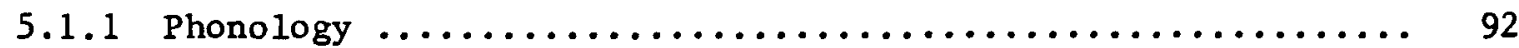

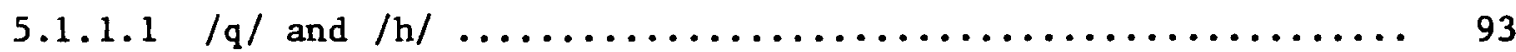

5.1 .1 .2 Other Phonological Characteristics ............... 93

5.1 .1 .3 Morphophonemics .......................... 94

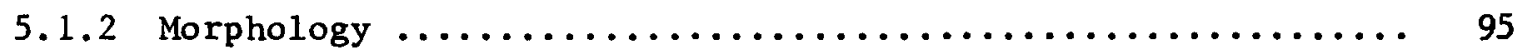

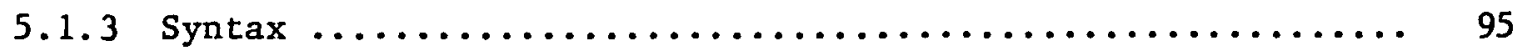

5.1 .3 .1 Dropping of Prepositions and Functors ............. 96

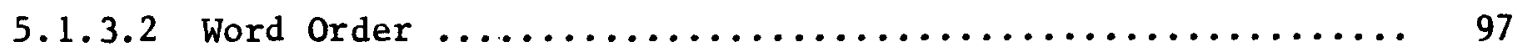

5.1.3.3 Use of Verbal Forms where Pribumi Javanese Prefers a Nominal Construction ........................ 97

5.1 .4 Lexicographic Peculiarities ..................... 98

5.1.4.1 Differences between Javanese Ngoko and Peranakan Speech of the Low Level ............................ 
5.1.4.2 Differences between High Level Peranakan Speech and

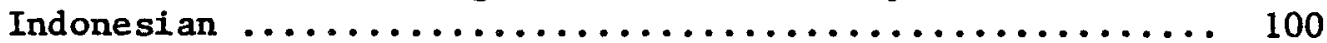

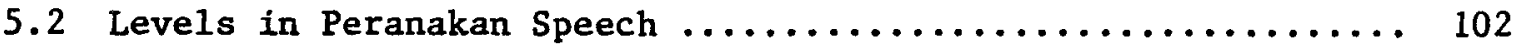

5.2.1 The Low and the High Levels $\ldots \ldots \ldots \ldots \ldots \ldots \ldots \ldots \ldots \ldots \ldots \ldots$

5.2 .2 Medium Level $\ldots \ldots \ldots \ldots \ldots \ldots \ldots \ldots \ldots \ldots \ldots \ldots \ldots \ldots \ldots \ldots \ldots$

5.2.3 Determination of Speech Level .................... 104

5.2.4 Stylistic Variation Apart from Speech Level ............ 108

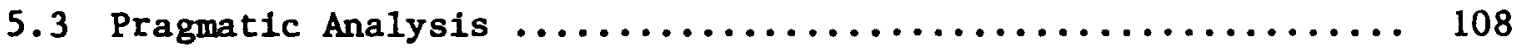

5.3.1 Mutual Exchanges of $H$ Level or Md Level Speech ........... 109

5.3 .2 High or Medium Reciprocated by Low $\ldots \ldots \ldots \ldots \ldots \ldots \ldots \ldots \ldots$

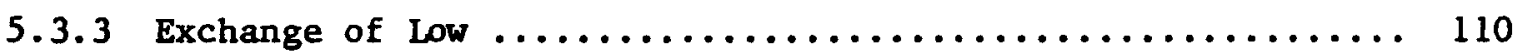

5.3 .4 Speech Level Used to Children .................... 110

5.3.5 Communication between Peranakan and Pribumi ............ 111

5.4 Code Switching ............................... 112

5.4 .1 In Quotations .............................. 112

5.4.2 Code Switching in Talking to Oneself (Non-Directed Speech) . 113

5.4.3 Functions of Non-Directed Speech .................. 113

5.4.4 Lowering or Raising Speech Level Because of Subject Matters Which Tend to be Discussed on a Certain Speech Leve1 ...... 115

5.4.5 Code Switching to Keep Two Conversations Apart .......... 116

5.5 Choice of Level as an Indicator of the Addressee .......... 117

5.6 Comparison of Peranakan Speech with Pribumi Speech ......... 117

5.6.1 Differences in the Form Which the Indonesian Admixture Takes 118

5.6.2 Comparison of Peranakan with Pribumi Speech from the Ethnographic Point of view ...................... 119

5.6.2.1 Difference in the Way that the Speech Level Systems Function .................................. 119

5.6.2.2 Differences in Factors Which Influence Speech Level Choice 120

5.7 What Language Do Peranakan Speak? .................. 121

6. IMPLICATION OF THIS STUDY FOR SOCIOLINGUISTICS $\ldots \ldots \ldots \ldots \ldots \ldots \ldots \ldots$

6.1 Function and Its Effect on Form .................. 123

6.2 Borrowing and Code Switching .................... 125

6.2.1 Character of the Borrowing as a Reflection of the Character of the Code ............................... 127

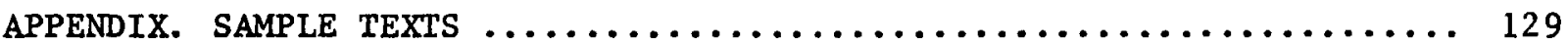


CHAPTER 1

INTRODUCTION

\subsection{The Setting}

This monograph is a study of the vernacular of the population of Central Java, Indonesia--that is, the speech which is used by the people of this area in their everyday interaction. This speech consists of large numbers of variants, clearly identifiable into sets, which we call 'codes', and the choice of code is dependent on cultural values and the social structure of the population. Examining code choice in Central Java, thus, is a means for discovering the cultural foundations of the community and for laying bare its social structure. Just as dissection or $x$-rays can reveal to the physician the principles which underly the symptoms perceived by the patient, so an analysis of speech variation or code choice can give us an inside view of what makes a society function and what are the basic cultural principles which motivate behavior. In this study we will observe speech variation and see how this variation is a means by which the society organizes itself and perpetuates its cultural traditions.

Central Java is a particularly interesting area of study for sociolinguistics because speech there has an unusually high amount of variation, divided into clearly recognizable codes, each with a clearly statable function. We shall see how cultural values determine code choice and how the subgroups making up the Central Javanese speech community put their cultural values into action through the codes they employ, or how the codes avallable to an individual speaker are determined by the subgroup, social or ethnic, to which he belongs. We shall also see something of interest to the theory of sociolinguistics: namely, that the functions of a code determine the code's formal features. Specifically, a code's functions determine the kinds of cooccurrence restrictions which will obtain and the kinds of grammatical features, if any, that constrain code switching.

Let us begin by giving some background information on Central Java and its language.

\section{1 .1 Javanese}

Javanese is the language of some sixty or seventy million people living in the eastern two-thirds of Java and most of the northern coast of Java except Jakarta. There are also large settlements of Javanese speakers in other parts of Indonesia, especially in southern Sumatra, and in New Caledonia and Surinam. The Javanese are the largest ethnic group in Indonesia and comprise almost half of Indonesia's population. Javanese speakers can be found in nearly every part of Indonesia.

Javanese is a member of the Austronesian family of languages which spread through much of the southern seas from Madagascar to Hawaii and Easter 
Island and from Formosa in the north to New Zealand in the south, with the exception of the island of New Guinea, all of Australia, and other areas with 'Papuan' languages. Within the Austronesian family Javanese is clearly in a subgroup together with other languages of western Indonesia, but it is impossible at this time to say more about the relationships of Javanese. It is very similar in structure to Indonesian and other languages of the area, but the genetic relationships are not very close.

Javanese and Malay (Indonesian) have for centuries strongly influenced each other and still very much continue to do so. As a result, the grammatical structures of the two languages are remarkably similar, considering that the genetic relationship is not very close.

Javanese is the vehicle of a great civilization and of a great literature going back almost uninterrupted to the tenth century. Since Indonesian Independence (1945), however, Javanese has been very much downgraded, and Indonesian has replaced it for many traditional literary functions and for most official purposes. Education in Javanese is confined to the lowest levels; Javanese language publications have a tiny circulation; and literary production is down to a trickle. It is a rare event that any literary production of merit comes into print. The Javanese themselves feel that their language has the status of a regional dialect and give to Indonesian the prestige of being the language of modernization. We shall discuss later (Chapter 3) the spread of Indonesian in the Javanese speech community and the functions which Indonesian has acquired.

Be that as it may, for more traditional pursuits Javanese enjoys prestige. It was the language of the old Javanese kingdoms, and it is still pretty much the only language used in court circles. It is thus the language associated with the nobility and has all the prestige that this usage gives it. It is also the vehicle of various theatrical arts which are still very much alive and have an important role in Javanese life. Most important, Javanese is the means for indicating to the world what sort of person one is, and it is essential for good interpersonal relations. Thus, despite the decline in prestige of Javanese from the point of view of modern life, in traditional aspects of life, Javanese still has great prestige, and the ancient traditions of proper language usage persist.

Proper language usage in Javanese involves the choice of variant vocabularies which is made according to the relationship between the speaker and the interlocutor and also according to other factors in the linguistic or extralinguistic context. One's ability to use proper language marks the kind of person one is. A person of priyayi 'gentlemanly' background speaks proper language, whereas others usually do not. The ability to use proper language is considered a sign of self-control and inner harmony which, among other things, is the key to maintaining an orderly society. These traditions of control of stylistic variations are still firmly entrenched and ure still essential for one's position in society and for good interpersonal relations.

\subsubsection{The Javanese Speech Community}

The Javanese speech community is by no means homogeneous. The sharpest split is between the Peranakan Chinese on the one hand and the Pribumi (natives) on the other. These two groups clearly form two subcommunities of the Javanese speech community by virtue of differences in their respective 
linguistic repertoires--i.e., differences in the linguistic codes which they obey. (See below, Sec. 1.4 for a discussion of these terms.) Here we will talk about the Pribumi community first, and only later (Chapter 5) discuss the Peranakan community. There are other non-Pribumi groups Iiving in Centra1 Java (Arabs, Indians, mixed-blood), but they are few in number and we have no information on their speech.

The Pribumi community itself could probably be further broken down from the point of view of different repertoires into groups that speak a clearly marked regional dialect, and groups that use only a portion of the repertoire available. We have done no more than make a few general comments about usage by various classes (Sec. 2.2.4).

\subsection{Speech Leve1s}

Javanese has a number of codes, the choice of which is dictated by the same types of factors, such as those of status and intimacy, that lead to the choice of $T$ or V (e.g., Russian ty or vy, French tu or vous) in European languages. These factors define the speech levels (unggah-ungguhéng bôsô), ${ }^{1}$ honorifics, and multiple terms of address and reference. We will discuss

1. We transcribe phonemically but give no intonation. Chart One summarizes the Javanese phonemic system. For the relationship between this and the orthography, see the introduction to Horne (1974). This work also gives an outline of the principal points of Javanese grammar.

CHART ONE

\begin{tabular}{|c|c|c|c|c|c|c|}
\hline Consonants & labial & $\begin{array}{l}\text { apico- } \\
\text { dental }\end{array}$ & $\begin{array}{l}\text { apico- } \\
\text { alveolar }\end{array}$ & palatal & velar & glotta1 \\
\hline fortis stop & $\mathrm{p}$ & $t$ & $t$ & c & $\mathbf{k}$ & $?$ \\
\hline $\begin{array}{l}\text { lenis stop } \\
\text { (pharyngealized) }\end{array}$ & $\mathrm{b}$ & $d$ & $\mathrm{~d}$ & $j$ & $g$ & - \\
\hline $\begin{array}{l}\text { prenasalized } \\
\text { voiced stop }\end{array}$ & $\mathrm{mb}$ & nd & nd & $n j$ & $\mathrm{ng}$ & - \\
\hline nasals & m & $\mathbf{n}$ & - & $\tilde{\mathfrak{n}}$ & a & - \\
\hline fortis continuants & $\mathbf{w}$ & $1, r$ & s & $\mathrm{y}$ & & \\
\hline $\begin{array}{l}\text { lenis continuants } \\
\text { (pharyngealized) }\end{array}$ & wh & $1 \mathrm{~h}, \mathrm{nh}, \mathrm{rh}$ & & yh & & h \\
\hline $\begin{array}{l}\text { other sounds found } \\
\text { only in foreign words }\end{array}$ & $\mathrm{f}$ & & $z$ & & & \\
\hline Vowe1s & front & central & back & & & \\
\hline high & i & & u & & & \\
\hline mid & e & & o & & & \\
\hline $\begin{array}{l}\text { low } \\
\text { very low }\end{array}$ & $\varepsilon$ & $\begin{array}{l}\mathrm{a} \\
\mathrm{a}\end{array}$ & 0 & & & \\
\hline
\end{tabular}


the terms of address and reference later (Sec. 2.3.1) but here will give a brief introduction to the system of speech levels and honorifics.

Javanese speech levels can be divided roughly into three: the highest, called Krômô (K); the lowest called Ngoko (N); and a middle level, called Krômô Madyô or just Madyô (M). There are no clear boundaries between these levels, and Madyô is a continuum between Krômô and Ngoko. The highest ${ }^{2}$ level, Krômô, is the refined level, marked by a special vocabulary of somewhat more than a thousand items and a few affixes for which there are special $\mathrm{K}$ variants. Krômô is employed to persons of high status. The term krômô is a borrowing of the Sanskrit krama 'in order', and the term krômô originally meant 'properly ordered speech'. The lowest level, Ngoko, is the unrefined level with which speakers choose to address persons with whom they are familiar and persons who are not of high status. Ngoko is marked by use of non-K forms for the 1,000 or so items for which there are special $K$ variants. Etymologically, the word ngoko is from the root koko 'say ko to someone'. Koko is a doubling of ko, an older (now poetic and dialectal) ${ }^{3}$ variant of kowé 'you (intimate)'. (However, the choice of terms of address is independent of speech level choice, and not everyone to whom one speaks Ngoko is addressed as kowé.) In between Ngoko and Krômô there is Madyô, which speakers use to persons of a high status with whom they feel at ease, or to persons of a low status whom they do not know and with whom they must be careful. Further, Madyô is used in place of Krômô by speakers who do not control Krômô. Madyô is a continuum between Krômô and Ngoko, and one speaks Madyô by using one of the thirty-five forms specifically assigned to Madyo, otherwise choosing either a $\mathrm{K}$ or $\mathrm{N}$ form (depending on how high a level of Madyô one is speaking). The term madyô is a borrowing from Sanskrit madya 'middle'.

These speech levels operate independently of the variations in formalinformal styles of speaking, or variations of the literary-colloquial or the fast, uninhibited speech vs. slow, consultative styles. Such variations exist on the $\mathrm{N}$ and $\mathrm{K}$ speech levels and to some extent on the M level. ${ }^{4}$

There is a further point to make about Krômô: Krômô is normally accompanied by special features, such as intonation and tempo which render it

2. The speech levels are traditionally termed higher or lower with respect to each other for reason that the higher the speech level the better the speech. Further, the higher the status of the person being addressed the higher the speech level which is chosen (although, as we shall see in Chapter 2, status is not the only factor which determines speech level choice).

3. The form kôg, the second person agent of a passive verb, most likely is a reflection of this ko.

4. Madyô originates as a colloquial, rapid-speech variant of Krômô. That is to say, Madyô now functions as a speech level (the factors which lead to the choice of Madyô are of the same type as the factors which lead to the choice of Krômô or Ngoko), but Madyô originated as a rapid or noncareful alternate of $\mathrm{K}$ forms, and this origin reflects itself in the fact that it is not possible to engage in very careful speech on the $M$ level. In the type of situation in which careful speech is called for, Madyô is not appropriate. For example, in Kethopraq dramatic performances (traditionally in literary language) either Ngoko or Krômô is used except by clowns or characters who are presented as unable to speak properly. On the other hand, rapid speech forms for Krômô have developed. 
more refined than Madyô or Ngoko. In addition, many of the rhetorical devices which Javanese consider to add to refinement, such as indirection, metaphor, circumlocution, and the like, are necessary concomitants to the $\mathrm{K}$ speech level, and, in a sense, the employment of these intonations and rhetorical devices is as much part of the speech level system as the specific vocabulary items we will discuss in this study.

In addition to the speech levels there are special honorific vocabularies, called Krômô Inggil (literally 'High Krômô') and Krômô Andhap (1iterally 'Humble Krômô'). These honorifics show respect and recognition of an interlocutor's or third party's high status. They are special terms which are used as substitutes for the normal term for a certain concept in order to give special honor to a person addressed or spoken about. They are used for the second and third persons only, almost never for the first person (for this would indicate a lack of proper modesty--a value we discuss later). Honorifics are, however, used for the first person by kings and in the practice of ngajari bôsô a usage which we will discuss later (Sec. 2.4). The Krômô Inggil (KI) vocabulary items refer to the actions of a particular person, his possessions, appurtenances, characteristics, and relations. They give honor to the persons addressed or referred to. The Krômô Andhap (KA) vocabulary items refer to actions of someone with regard to the person addressed or a person referred to. We discuss these honorifics later in Sec. 2.3.1. In this study we do not list these various honorifics or speech level forms. A complete listing of those found in the present-day speech of Central Java is given in Supomo (1968).

The KI and KA honorific vocabularies are traditionally referred to as a kind of speech level, but in fact they operate quite independently of the speech levels, in that they occur, whenever their use is appropriate, at a11 speech levels. A person of sufficiently high status to be addressed on the $\mathrm{K}$ level would most certain1y be addressed with at least some KI and KA forms, but that is about the only existing correlation between the honorifics and the speech levels. The $\mathrm{K}$ forms, $\mathrm{M}$ forms, the honorifics (KI and KA forms) are called in Javanese Bôsô, and to use them is termed mbasani and mbasaqaké 'speak Bôsô'.

Chart Two is a schematic presentation of the speech levels and honorifics. A Javanese utterance can be thought of as being anywhere on the surface of this block or within it: the closer it is to the front of the block, the more colloquial in style; the further back within the block, the more formal in style; the further to the left, the more Ngoko in style; the further to the right, the more Krômô; the closer to the bottom, the fewer the honorifics; the closer to the top, the greater the number of honorifics. It must be borne in mind that this chart represents a continuum between Ngoko and Krômô (everything not pure Ngoko and not pure Krômô being called Madyô), and between all possible honorifics and their total absence. Formality or colloquialism is similarly a matter of degree. 
Schematic Representation of Speech Level, Honorific, and Formal Variations

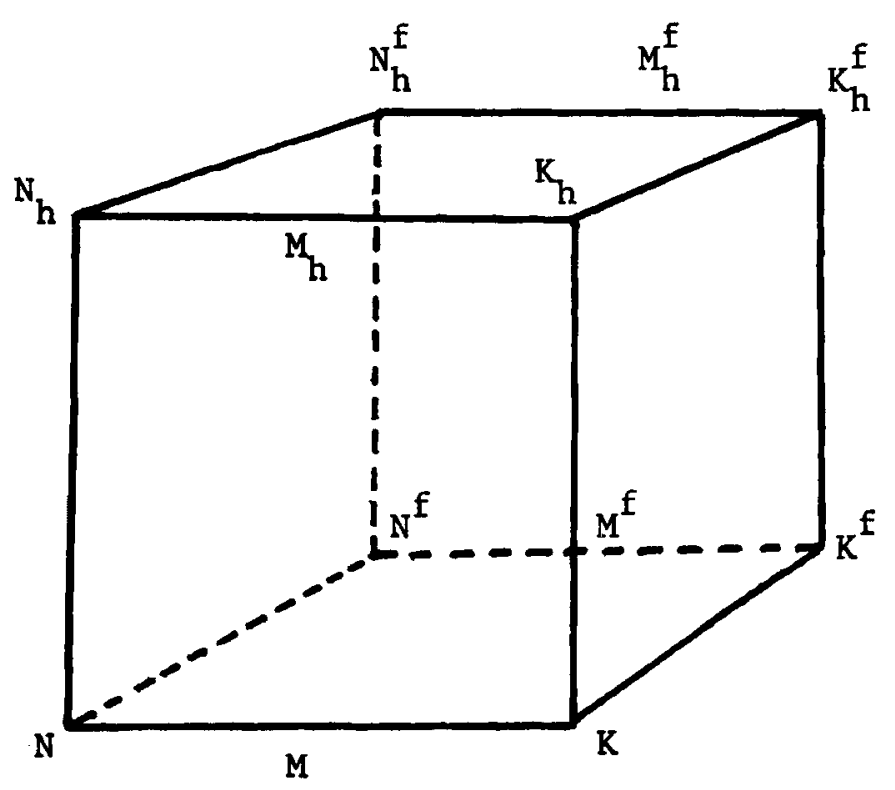

$\begin{array}{llll}\text { N } & \text { Ngoko } & \mathrm{X}^{\mathrm{f}} & \text { formal variety of speech level } \mathrm{X} \\ \mathrm{M} & \text { Madyô } & \mathrm{X}_{\mathrm{h}} & \text { speech level } \mathrm{X} \text { with honorifics } \\ \text { K } & \text { Krômô } & \mathrm{X}_{\mathrm{h}}^{\mathrm{f}} & \text { formal speech level } \mathrm{X} \text { with honorifics }\end{array}$

Examples of the various speech levels with and without honorific vocabulary:

$\mathrm{K}_{\mathrm{h}}$ (with KI): Kulô sampon diponparingi Bapaq. Father gave me some. (The root PARENG 'give' is $\mathrm{KI}$; the affix PON is K; KULÔ ' $I$ ' is $K$ or M; SAMPON 'already' is $K$. )

$\mathrm{K}_{\mathrm{h}}$ (with KA): Bapaq sampon kulô caôsi. I gave father some. (CAÔSI 'give to' is $\mathrm{KA}$.)

K: Pon Tômô sampon kulô sukani I gave Tomo some. (PON 'title for a familiar person' is $\mathrm{K}$; SUKANI 'give to' is $\mathrm{K}$ or M.)

$M_{h}$ (with KI): Kulô mpon diparingi Bapaq. Father already gave me some. (MPON 'already' is M.)

$M_{h}$ (with KA): Bapaq mpon kulô caôsi. I already gave father some.

M:

Si Tômô mpon kulô sukano. I gave Tomo some. (SI 'title for a familiar person' is Mor N.)

$\mathrm{M}_{\mathrm{h}}$ (lower with KI): Niki arep diparéngké sinten. Who will they give this to? (AREP 'future marker' is $N$ or low $M$. NIKI is $M$, SINTEN 'Who' is $M$ or K.) 
$M_{h}$ (lower with KA): Bapaq nggêh arep dicaôsi. They will also give father some. (NGGÉH is M.)

$\mathrm{N}_{\mathrm{h}}($ with KI):

Aku wés dịparingi Bapaq. Father has already given me some. (WES 'already' is $\mathrm{N}$; aku ' $\mathrm{I}$ ' is $\mathrm{N}$.)

$\mathrm{N}_{h}$ (with KA):

Bapaq wés taq caôsi. I already gave father some.

(Tag 'by me' is N.)

N:

Si Tômô wés taq kèqi. I already gave Tomo some.

In addition to these codes, there are also various varieties of court speech called the Krômô Bagôngan, still used in the royal courts of Surakarta and Yogyakarta and imitated on the stage, which we do not discuss here.

\subsubsection{Meaning Relationship of the Level and Honorific Vocabularies}

The $\mathrm{K}$ and $\mathrm{N}$ forms are almost congruent in referential meaning--that is, each $N$ form and its $K$ analogue have identical referential meanings, apart from the speech level connotation. As an example we take $\mathrm{N}$ wông $\mathrm{K}$ tiyang. Tiyang has all the same meanings as wông: 'person, because, expression of deprecation, a request for verification, etc.' 5 The same applies to the few special $M$ forms, which have exactly the same range of meanings as their $K$ and $\mathrm{N}$ counterparts. There are a few isolated cases where one $\mathrm{K}$ form is analogous to two $\mathrm{N}$ forms. For example $\mathrm{K}$ badhé is the analogue of both $\mathrm{N}$ arep 'future marker' and $\mathrm{N}$ baka1 'cloth'. The speech level distinctions in Javanese, then, differ from the stylistic variations of English vocabulary, for example, where a fancy form rarely coincides exactly in meaning with a less fancy form. This can be seen in the three forms get, obtain, and procure, which; although progressively higher forms expressing the same referential meaning, are by no means congruent in their referential meanings: get has a much wider range of meanings than obtain, which in turn has a wider range of meanings than procure. (But again procure is used in different senses from get and obtain, and so forth.)

The case of the Javanese honorific ( $K I$ and $K A$ ) vocabulary is quite different from that of the $K$ and $M$ vocabulary. The honorific vocabulary invariably covers a much larger range of references than the $K$ and $N$ form for which it substitutes. That is, one $\mathrm{KI}$ or $\mathrm{KA}$ form may serve as the honorific of a number of $\mathrm{K}$ and $\mathrm{N}$ forms. For example, $\mathrm{KI}$ astô means 'hand, bring, do, hold, teach'--i.e., it is the $\mathrm{KI}$ for $\mathrm{N}$ or $\mathrm{K}$ tangan 'hand', $\mathrm{N}$ gôwô $\mathrm{K}$ bektô 'bring', $N$ gawé $K$ damel 'do', $N$ wulang $K$ wucal 'teach', $N$ cekel $K$ cepeng 'hold', and other forms which have similar meanings. Similarly KA ator 'say, invite, call, tell, advise, give, show' is the substitute for a large number of $\mathrm{K}$ and $\mathrm{N}$ forms which have these meanings. The following sentences show how the honorific vocabulary substitutes for the nonhonorific vocabulary.

5. Historically, tiyang probably began as the Krômô for wông 'person', and wông in its various conjunction meanings was still Krômô. This seems likely because tiyang in its conjunction meanings is used only in the highest types of Krômô, whereas tiyang in the meaning of 'person' is used in Madyô and even low Madyô. Since Krômô is an at tempt to fancify speech, the use of tiyang spread from the original meaning of 'man' to all of the other meanings which wông carries. 
1a. Kéngéng manôfô astô penjenangan? What happened to your HAND?

b. Wadhuh, tangan kulô sakét. Ouch! My HAND hurts!

2a. Penjenengan badhé ngasto buku menikô. You will BRING that book.

b. Kulô badhé mbektô buku menikô. I will BRING that book.

3a. Penjenengan badhé nggastô wônten pundi? Where will you WORK?

b. Kulô badhé nyambot dame1 wônten mrikô. I will WORK there.

4a. Penjenengan ngastô wônten sekolahan menikô. You TEACH in that school.

b. Kulô mucal wônten sekolahan menikô. I TEACH in that school.

5a. Keng Rômô anggènipon ngastô pulpén meniko lucu sanget. Dad IS HOLDING that pen in a funny way.

\subsubsection{On the Origin of the Speech Leve1s}

Although no studies on the historical development of the speech levels have been undertaken, comparing Javanese speech levels with speech level usage in other parts of Indonesia should cast some light on this. Speech levels exist in Sunda, Madura, Lombok, isolated parts of the Malay-speaking area, and in Bali, where speech level usage may be particularly important because it has close connections with religion. The usage of the courts where archaisms are preserved might provide further illumination. Also comparisons with speech levels and caste dialects in south India may possibly help explain the original functions of the speech levels, as it may turn out that Javanese speech levels are historically related to those of India. ${ }^{6}$

Be that as it may, it is most probable that the speech levels represent stylistic variations which have their origin in the times of strong Indian influence in Java. For one thing, much of the current Bôsô $(M, N, K I$ and KA) vocabulary is Sanskrit in origin, even though the great majority of Bôsô vocabulary consists of analogical creations. Further, the degree to which Bôsô is ingrained makes it likely that speech levels have been in wide use for centuries. Bôsô is an important feature of all speech areas and of the language used by all segments of the native (non-Peranakan) population (except perhaps by the elite classes, who are the most mobile and subject to outside influences, and who sometimes bring their children up to speak Indonesian). But its original function, and with whom and when it began, we do not know. Our specimens of old Javanese are not of much help in this respect.

6. The language of India can surely provide much information on the development of Javanese speech levels. For example, in modern Tamil there are two words for 'house': akam, the form used in the Brahmin dialect, and vitu, the form used in the dialects of the other casts. The form akam also is used in non-Brahmin dialects to mean 'interior'. This usage brings to mind Javanese usage, where the ordinary word (Ngoko) for 'house' is omah, and the honorific (Krômô Inggil) is dalem. By comparing cognates in related languages we know that dalem developed from a word which originally meant 'inside'. This semantic development in Javanese is surely not unrelated to the Tamil deve1opment. The study of phenomena of this sort is likely to yield information on the origin of the Javanese speech levels. 
01d Javanese texts are highly literary and artificial in style, but they clearly show honorifics. A theory that Bôsô began as hybrid Sanskrit used with certain castes or for certain religious functions would certainly accord with all that we now know; but other hypotheses could also account for the known facts.

\subsubsection{Comparison of This Analysis with Other Analyses}

The Javanese speech levels have been frequently analyzed, and in many respects the findings which we present here are in accord with the picture which is usually presented. There are, however, some differences between our description and previously presented descriptions, the best known of which is the one of Geertz. We differ from this in two important respects: first, we present the Krômô-Madyô-Ngoko variations as a continuum, whereas Geertz presents them as completely separate points, without allowing for the possibility of in-between forms. Geertz's description implies that an utterance is either Ngoko or Madyô or Krômô and that these three levels are clearly marked; whereas we view the Ngoko-Madyô-Krômô distinctions as a cline. Utterances can fall anywhere on an unspecifiable number of points between those which are definitely Ngoko and Krômô. The M level ranges from something just above pure Ngoko to utterances close to pure Krômô. For the $M$ level, there is an unspecifiable number of gradations closer to or further from pure Krômô. There are, to be sure, cooccurrence restrictions (2.1).

There is a further important difference between our analysis of the speech-level system and that of Geertz. Geertz states that there are two kinds of honorifics: high (our KI and KA forms) and low, which consist of $\mathrm{K}$ forms used as honorifics. In our materials we found only a small number of $\mathrm{K}$ forms which are actually used as honorifics (Sec. 2.2.8), and, with a few exceptions (e.g., the names of body parts as discussed in 2.2.8), these $\mathrm{K}$ forms are used as honorifics because there are no special KI forms. Uhlenbeck (1972) also questioned Geertz's analysis on this point. Geertz also states that honorifics do not occur with Madyô, but this is clearly not the case. The honorifics may occur with any speech level, a fact which is illustrated by numerous examples we have recorded, some of which are cited in this study. Uhlenbeck illustrated this by a quotation from literature.

\subsection{Indonesian as a Code}

In addition to the stylistic variations which we have described above, the Javanese use Indonesian as a high language in a way which is analogous to the use of high languages in communities in which the situation of diglossia ${ }^{7}$ prevails. Among the Javanese (other than the Peranakan Chinese to whose speech we devote a separate chapter) Indonesian fulfills many of the functions which are typically assigned to the high language in diglossic communities: it is the language of education above the basic level, the language of official functions, the language of offices and businesses above the bazaar level, the language of the most widely read newspapers, and the

7. The term diglossia refers to the phenomenon whereby a single community employs two varieties of speech for daily use: a primary language or dialect, used for ordinary, everyday purposes; and another variety of language learned largely by formal education and used for most written and formal spoken purposes, but not used by any sector of the community for ordinary conversation. 
language of much of the broadcasting industry. Public signs are in Indonesian, and so forth. We discuss this use in greater detail in Chapter 3.

\subsection{The Methods and Aims of This Study}

What we have described heretofore is common knowledge, and the principal difference from widely accepted notions about Javanese speech levels is that we clearly distinguish honorifics and pronoun choice from speech levels, and distinguish both of these from other sorts of stylistic variation. Further, we recognize that the speech levels are not separate entities but a continuum, and that Indonesian functions as one of the codes used by this speech community. The contribution we hope to make in this study is to elucidate how speech expresses the culture of Central Java. The ethics and aesthetics which motivate Javanese behavior are put into action by their speech choice and are the ultimate principles guiding this choice. We shall take a look at the Javanese system of values and its relationship to speech choice and indicate how speech choice is a key to understanding social

interaction. Central Java with its two communities, the Peranakan (population of Chinese descent) and the Pribumi (the native Javanese), speaking the same language though culturally diverse, offers an excellent example of how code repertoires and code choices express the culture of the speakers (see Sec. 5.3.4.2ff. below).

Typologically, Central Java presents a linguistic situation of great complexity and interest. There are four important sources of variation, all of which operate independently from one another. First, the community is diglossic, with Indonesian occupying a function very much analogous to the function of codes which have been described as a high form in diglossia. Although there are points at which the situation in Java differs from those described by Ferguson (1959), there are reasons for considering the Javanese speech community (both subcommunities, the Pribumi and the Peranakan) to be diglossic (Sec. 6.1, below). Second, Javanese has speech levels which consist of divergent and readily identifiable vocabularies with a one-to-one relationship to each other. This two-tiered set of speech-level vocabulary exemplifies a speech situation of quite a different sort from diglossia (which also operates on a two-tiered sort of vocabulary), for the alternative forms are either chosen on the basis of entirely different principles or function in an entirely different way from the high and low forms of diglossia. Third, there is the system of honorific vocabulary, and the series of terms of address and first and second-person pronouns which, together with the speech level, express cultural factors of a sort similar to the $T-V$ distinction of European languages. Finally, there is stylistic variation of the slow, consultative styles as opposed to careless, rapid-speech styles; or literary-archaic styles as opposed to everyday speech styles; or intimate styles with regionalisms as opposed to styles more suitable for public consumption. Although these sources of variation express a unique culture and function in a way which is peculiar to Javanese society, the features of sociolinguistic meaning which give rise to variation are comparable to those which give rise to variation in other speech communities. The manner in which the code repertoire of the Javanese community handles these features of sociolinguistic meaning, as compared to other communities whose speech expresses analogous features with a code repertoire of typologically quite a different nature, is of great importance to our understanding of what 
codes are and how they express a culture. ${ }^{8}$

Our study is confined to Central Java (Yogyakarta and the surrounding towns). Our first step was to find out empirically the existing variations and especially what the speech levels consist of, and from there to draw conclusions as to how these variants group into codes, how they are employed, what functions they serve, and how they put into action the value systems as otherwise expressed by the community. Our method was to look at the vernacular--that is, at the everyday language which is used by members of the speech community in going about their normal day-by-day activities. We made recordings of on-going conversations involving as wide a variety of contexts as possible and the largest possible varlety of speakers. These conversations were recorded, on a Sony $\mathrm{TC}-55$ recorder with all recording equipment concealed except for a tiny external microphone, usually unbeknown to the participants except the person making the recording. A selection from the transcription of these recordings is presented in the appendix. The recordings were all made by native Javanese, usually within their circle of acquaintances, ${ }^{9}$ and transcribed literally by the person who made the recording. The transcriber appended a detailed commentary as to other factors, linguistic and extra-linguistic, not determinable from the text of the recording, but known to him (identity of the participants, general atmosphere, who is addressed, references to things outside of the conversation, and the like). Very little appears in our tapes which was affected by the circumstance of

8. Friedrich $(1972:$ 278) suggests that there may be universal components which map pronoun choice and social structures. There is ample evidence in the data here to support this proposition in principle, although it is clearly not always pronominal choice, but rather other sources of variation which express these components. In many instances the situations described by Friedrich are analogous to situations which obtained in the conversations which we recorded, and the meanings which code choice in our materials express are in many ways comparable with the meanings which pronominal choice expresses in Friedrich's examples. It is interesting to compare the way in which these meanings are expressed by the codes available for Javanese and the types of variation available to Russians. For example, Friedrich relates how Russian vy may at the same time express mutual respect and consideration in an affectionate relationship between confidants of a certain class, as in the example of the officer and surgeon who room together at a result (279), and also at the same time may express distance and coldness, as in Lermontov's example of the aristocratic lieutenant and the simplehearted older captain (287-8). In Javanese a different sort of choice is available to express much the same meaning. To express affection and intimacy one chooses Ngoko, but the feeling of respect and consideration can still be maintained by the choice of honorifics and pronominal choice and choice of term of address (cf. 2.3.2, below). On the other hand, cold distance may be expressed by a choice of Krômô or Madyô as opposed to Ngoko, as for example in the second citation of Sec. 3.4.1 below, where a student classifies his interlocutor as an outsider by responding to his Ngoko with Krômô.

9. The American co-author, John Wolff, was present at only two of the recording sessions. His presence affected the contents only insofar as things addressed directly to him were invariably in more formal, high level Javanese than would normally be used to native Javanese of the same status and relationship. 
recording: occasionally we detect efforts to stimulate conversation or keep a faltering conversation going, but few of the participants were ever aware that they were being recorded, and, on the whole, the conversation was normal for the situation. The total number of recordings amounted to some 150 hours of speech.

In the year and a summer during which this project ran, we could give our personal careful analysis to only a small portion of the tapes, and for the remainder had to rely on notes of the people who made the recordings. Since much of analysis relies on personal judgment or interpretations of intent, our analysis is by no means wholly free of arbitrary or biased decisions. We do, however, always discuss the basis for our conclusions, and we have tried to find ways to substantiate them by other means.

The conversations can in no way be said to represent a random sampling of conversations taking place in Central Java. In the absence of anything more than the most generalized sociological information as to the make-up of the community, we could do little more than sketch out rough social categories and endeavor to record conversations which involve the various permutations of these categories. Our recordings were also restricted by questions of access. For example, the number of conversations involving Santri (strict Muslims) is small, not enough to enable us to determine empirically any difference in the speech-level usage of Santri as opposed to other Javanese (Abangan). Similarly, our recordings of the speech of the court are very limited.

\subsubsection{Terminology}

We have tried to confine ourselves to terms current in linguistic and sociolinguistic literature. The terms 'speech level' and 'honorifics' are defined in Sec. 1.2. We also use in passing terms such as 'stylistic variant', 'pragmatic factor', 'code', 'function', 'speech', and 'speech community'. The meaning of STYLISTIC VARIANT is roughly the same as Gumperz's term sociolinguistic variable (Gumperz and Hymes 1972: 18-20): stylistic variants are alternate forms with the same denotation (forms that are referentially equivalent) whose selection carries social significance for some speaker (the choice of which is determined by factors of social context such as scene, setting, key, subject matter, speaker, interlocutor, other parties present or involved, and others--cf. Gumperz and Hymes 1972: 35-71). The meaning which is carried by the choice of a stylistic variant is termed a PRAGMATIC meaning (Silverstein 1976), and a factor of social context which gives rise to a certain pragmatic meaning is termed a PRAGMATIC FACTOR. Stylistic variants tend to occur in groups (cooccurrent clusters--Gumperz and Hymes 1972: 21). Groupings of stylistic variants which tend to cooccur we call a CODE. Each code has a meaning. From a sociolinguistic point of view the meaning of a code is its FUNCTION, ${ }^{10}$ the purpose which the code serves. The function of a code can be described in terms of the factors which motivate code selection (the factors of scene, setting, key, etc.,

10. It is also possible to describe the meaning of a code in psycholinguistic terms or in terms of the ethical principles that underlie the code choice. Geertz's description treats the speech level usage from this point of view, and we also give our intuitive interpretations in these terms in Sec. 2.1ff. 
mentioned above) or it can be described in terms of reactions by members of the speech community to code selection. We use the terms SPEECH AND SPEECH COMMUNITY in the commonly accepted sense (Gumperz and Hymes 1972: 53, 54). Speech is the sum total of forms which an individual uses on a single occasion or on many occasions (or the surrogate thereof--writing, etc.). A speech community is a group which shares rules for the conduct and interpretation of speech and rules for the interpretation of at least one code. 
CHAPTER 2

THE FUNCTION OF THE SPEECH LEVELS

\subsection{Javanese Values and the Meaning of the Speech Levels}

By analyzing the meaning of each speech level in terms of the underlying values of Javanese society and the feelings of members of the speech community toward these values, we can come to an understanding of the functions of the speech levels in implementing them.

The basic theme of Javanese ethics is tôtô tentrem, which is a twofaceted ethic encompassing tôtô 'in proper order, everything in its proper place' and tentrem 'peace and calm'. For the Javanese, correct behavior is directed toward the achievement and maintenance of tôtô tentrem, and, in the final analysis, all Javanese values are justified as a means of achieving or maintaining tôtô tentrem. In these terms, humility, indirection, refined bearing, and other modes of conduct are all valued behavior.

The two facets of tôtô tentrem are mutually dependent. Tôtô means an ordered universe with everything properly placed and harmonious. Tentrem means that the beings making up the universe are calm and serene within themselves (feel what is called tentrem ayem) and at peace with one another (called sayoq rukon or simply rukon). Without order there can be no peace, and without peace there can be no order. Thus, right conduct is seen as striving to create and maintain feelings of ayem tentrem within oneself and one's fellow-beings and sayog rukon within the community. Together, these form the basis for refined behavior and extreme tact upon which Javanese put a great deal of emphasis.

The ethic of tôtô tentrem is reflected in all facets of behavior, but we shall here simply follow it up from the point of view of social stratification. The notion of tôtô gives importance to status. Each member of the community must have a place and must make his behavior conform to his position. The rules of conduct for achieving this confirmity are called tôtô krômô, and persons who engage in proscribed behavior are said not to know tôtô krômô. Tôtô krômô eflects itself prominently in speech, with its rules providing the motivation for the speech level choice (choice of Krômô, Madyô, Ngoko, or honorifics). The tôtô krômô of language is called unggahungguhéng bôsô 'various speech proprieties'. Sreg (/srek/) is the feeling engendered by the knowledge that the speaker and interlocutor have been properly placed vis-à-vis one another and in the community as a whole. In terms of speech, sreg is the feeling that the form chosen accords with unggah-ungguhéng bôsô. For example, it is sreg for a child to address or refer to his parents with honorifics, but it is not sreg for parents to do so to their children because employing or failing to employ honorifics defines the relationship between the child and the parents. 
The members of the community feel tentrem ayem (at peace) if they engage in conduct which feels sreg and if the people who interact with them a11. do things that are sreg. Thus, the feeling of ayem tentrem is engendered by acting in accordance with one's place, behaving respectably (in bearing, dress, speech, deeds), and recognizing the status of the other members of the community. Towards a person of higher status one has a feeling of respect or embarrassment from fear and awe. This feeling is called pekéwoh or rikoh (East Java: sungkan). One maintains a respectful distance from people of higher status, keeping oneself figuratively and literally below them, and only approaching them with extreme circumspection and clear signals of deference. For example, an employee who comes to the boss's house waits unobtrusively until the boss chooses to speak to him. One feels pekéwoh to do something ahead of a person of higher status, and it is this feeling which prevents a person from eating in the presence of someone of higher status without permission, and so forth. Humility or recognition of another's higher status is called andhap asôr.

In order to feel ayem tentrem we must not only recognize the place of those with whom we interact, but we ourselves must also be accorded proper status. We must engage in conduct that is sreg, but others must also do so with respect to us. We must have feelings of pekéwoh to those above us, and those below us must feel pekéwoh toward us. The need to elicit behavior that is sreg in others is the basis for a value termed tepô slirô 'putting oneself in the other's place' or 'acting towards others as you would have them act toward you'. This notion implies that one's own behavior reacts upon oneself: if I fail to give my interlocutor his proper status, he will also fail to give me my due; but if I show him proper respect, he will in turn respect me. The following anecdote illustrates how tepô slirô manifests itself in conduct: A fifty-year-old stranger comes to a village and asks a local child aged nine or so for directions. He uses a Madyô speech leve1. As we sha11 see shortly, Madyô is too high to give to a child. Ngoko, the lowest level should do, for it is felt to be perfectly sreg to address children with it, specially village lads. We asked the stranger why he had chosen to address the child in Madyô when Ngoko was perfectly all right. The stranger replied that he was afraid that the child might respond in Ngoko. The feeling of tepô slirô, then, led the stranger to choose Madyô, the feeling that he must behave in such a way as to elicit sreg behavior from the child.

According to this notion of tepô slirô humble behavior (andhap asôr) has positive value. By behaving humbly one gives status to one's interlocutor. This humility will be returned, and thus one's own status gets recognized.

Having outlined some of the ethical notions guiding Javanese behavior, it is now possible to discuss some of the factors which motivate speech level choice with reference to how members of the speech community themselves feel about them. First and foremost among these motivating factors is what might be termed status, for it is status which elicits the feelings of pekéwoh which underlie tôtô tentrem. From the point of view of pekéwoh two aspects of status act independently: class and age.

Among the most important factors which determine class are birth, ethnic grouping, family affiliation, occupation, and wealth. The two classes traditionally recognized are priyayi 'gentlemen' and wông cilég 'small people'. The term priyayi originally applied only to people of noble blood, 
people who claimed descent from the Hindu priestly and warrior castes, but in recent generations this notion has been progressively extended so that it now includes people of education with white collar occupations and wealth (at least of a moderate amount). These groups, however, do not have as high a status as the priyayi by birth, and people do not necessarily behave toward them as consistently as they do toward priyayi. Thus, there is a wide range in status among the priyayi, and these various class differences give rise to different degrees of pekéwoh and, in turn, reflect themselves in speech level usage.

The other status factor is age. Age is not entirely absolute from the point of view of the feelings of pekêwoh: married couples are normally accorded the same age status (that of the older spouse), even when there is a great gap in years. For the purposes of ceremonies one's status is reckoned in terms of the generational distance from a certain ancestor (i.e., all consanguines are given the same age status), and this way of reckoning may also be carried into other behavior. Occasionally consanguines are given the same age status (that is the higher status) even when there is a generational difference between them. For example a parent's younger sibling may be treated like a parent, even when in reality he is of the children's generation.

The other factor which is connected with the feeling of pekewoh is intimacy. In an intimate relationship there is little fear of upsetting tôtô tentrem, and if parties are intimate their mutual status is clearly understood. Feeling secure in this knowledge, many overt signs of pekêwoh may be safely toned down. Intimacy is primarily dependent on relationship and intensity of association, but is also affected by age, class, and factors of individual personality. We asked the informants (the ones who made the recordings) to judge the degree of intimacy between the persons recorded. They were to be regarded as intimate (akrab) with each other if two conditions were fulfilled: if each was secure in his position vis-à-vis the other party; and if they were closely acquainted.

Three PRAGMATIC FACTORS (components of sociolinguistic meaning), thus, give rise to speech levels: class, age, and intimacy. These factors define the speech levels clearly, but there are points of tension in the system where they conflict, and at these points considerable variation in speech level usage is manifested. Further variations in speech level usage are evident because of the fact that class and intimacy are themselves open to varying personal interpretations.

Ngoko is the basic speech level and Krômô and Madyô are simply ways of making $N$ speech elaborate. Ngoko is the first thing a child learns (as we shall discuss later in Sec. 2.4), and it is the speech used when one is least inhibited or controlled. $N$ forms are used in talking to oneself and in talking of beings with whom one has no feeling of pekéwoh: children, dogs, intimates not of higher rank, and the like. It is the speech which comes out in uncontrolled anger, when one is taken aback, confused, or when one should perhaps feel pekéwoh but does not.

Intimacy is a necessary condition for Ngoko, and is the pragmatic factor (factor of sociolinguistic meaning) running through it, but not all intimates are addressed with Ngoko. As we shall see, age and class factors which lead to a higher level choice serve as a point of tension, and where these factors come into play there is fluctuation or variation in usage. 
The most careful and highest speech level is Krômô, which shows the greatest control and the strongest feeling of pekewoh toward the interlocutor. Krômô is the code addressed to persons of priyayi status, and to use Krômô is to ascribe this status, even when the people addressed are clearly not priyayi. Such usages are temporary, and they usually have a rhetorical function. (We discuss individual examples later in Sec. 4.3.3.) Krômô thus ascribes priyayi status, but priyayi are not invariably addressed with Krômô. First, they receive lower levels of speech from speakers who do not control Krômô (Sec. 4.4.1). Priyayi children may receive either Krômô or Ngoko, for there are two pragmatic factors which lead to conflict in code selection (Krômô chosen for priyayi status, and Ngoko for intimacy). Further, there is variation and fluctuation in $\mathrm{K}$ use, arising not out of conflicting pragmatic factors, but rather from the latitude one has in placing a person as a priyayi. Since the priyayi class has itself now expanded, people who are not in the top echelons of priyayi or whose status does not derive from noble birth are not addressed with Krômô by people who know them (or are slightly intimate). Lower priyayi, especially those at the bottom ranks (e.g., petty clerks and the like), elicit no strong feelings of pekéwoh, and a lower speech level is appropriate (still gives a feeling of sreg). (It is usually Madyô which is chosen, as we shall see immediately below.)

Between Krômô and Ngoko is the Madyô level. In origin Madyô is a relaxed or careless form of Krômô, consisting ofL (1) a mixture of $\mathrm{K}$ and $\mathrm{N}$ forms; (2) abbreviated $\mathrm{K}$ forms; and (3) a few other forms which the community regards as neither as careful as Krômô nor as relaxed as Ngoko. 'Madyô is not a set of fixed forms, but is rather a cline rising from a level very close to Ngoko up to a level very close to Krômô. The height of the M level depends on the mixture of Ngoko and Krômô and the degree to which the $\mathrm{K}$ forms are abbreviated. The greater the percentage of $\mathbf{N}$ forms and the more truncated $\mathrm{K}$ variants that are chosen (or the greater the amount of truncation), the lower the M level.

Four different combinations of factors give rise to Madyô. First, speakers who do not control Krômô can substitute the closest Madyô they can muster, and priyayi class ascription motivates its choice, as in the case of Krômô. Second, Madyô has become the code which signals non-intimacy for persons who are perceived to be less than priyayi class--i.e., the factor of non-priyayi status and non-intimacy gives rise to Madyô. Formerly, priyayi invariably addressed wông ciléq with Ngoko, and this usage is still observed by some ultra-conservative priyayi who view Madyô as a careless or uncontrolled form of Krômô and avoid it for this reason. However, the values of tepô slirô 'be in another's place' and andhap asôr 'be humble' work against this usage, and Madyô is the compromise adopted by the vast majority of members of the speech community. Madyô thus may mean non-priyayi status and non-intimacy. There are numerous status gradations (it is impossible to state precisely how many), and the lower the status, the lower the type of Madyô received.

Third, Madyô has also acquired a meaning of intimacy. This development has come about because of the expansion of the lower priyayi group (people who are priyayi merely by virtue of working at white collar professions). Priyayi who are lower than the very top class (the priyayi by birth) may receive Krômô from strangers, but from people who have established personal relations--not necessarily intimate, but familiar--with them, they receive Madyô. Thus the factor of intimacy leads to a choice of Madyô in the case 
CHART THREE

The Pragmatics of the Speech Level System

\begin{tabular}{|c|c|c|c|c|c|c|c|c|c|}
\hline & & \multicolumn{8}{|c|}{ Receiver } \\
\hline & & \multicolumn{4}{|c|}{ priyayi } & \multicolumn{4}{|c|}{ non-priyayi } \\
\hline & & \multicolumn{2}{|c|}{$\begin{array}{l}\text { not older than } \\
\text { speaker }\end{array}$} & \multicolumn{2}{|c|}{$\begin{array}{l}\text { older than } \\
\text { speaker }\end{array}$} & \multicolumn{2}{|c|}{$\begin{array}{l}\text { not older than } \\
\text { speaker }\end{array}$} & \multicolumn{2}{|c|}{$\begin{array}{l}\text { older than } \\
\text { speaker }\end{array}$} \\
\hline & & intimate & $\begin{array}{c}\text { not } \\
\text { intimate }\end{array}$ & intimate & $\begin{array}{c}\text { not } \\
\text { intimate }\end{array}$ & intimate & $\underset{\text { not }}{\text { intimate }}$ & intimate & $\begin{array}{c}\text { not } \\
\text { intimate }\end{array}$ \\
\hline \multirow{2}{*}{ Giver } & priyayi & $\mathrm{M}, \mathrm{N}$ & $\mathrm{K}$ & $\mathrm{K}, \mathrm{M}$ & $\mathrm{K}$ & $\mathrm{N}$ & $\mathbf{M}$ & $\mathbf{N}$ & M \\
\hline & non-priyayi & $\mathrm{N},(\mathrm{K})$ * & (K) & (K) & (K) & N & M & $\mathrm{N}, \mathrm{M}$ & M \\
\hline
\end{tabular}

* We put parentheses around these symbols because generally non-priyayi do not control Krômô (Sec. $2.2 .2,4.4 .1)$, and in these cases they use the closest to Krômô that they can muster. The symbol (K) represents Krômô or the nearest approximation to Krômô available to the speaker. 
of lower priyayi. Again intimacy or familiarity can be of a greater or less degree, and the greater the degree of intimacy, the lower the variety of Madyô given.

Madyô or Krômô may also be given to older close relatives, but in this case the factors of class and intimacy conflict. In upper class families the priyayi status of an older relative gives rise to Krômô; and in families of lower class, Madyô. But in all families, whatever their class, the factor of intimacy may dominate, and in some families some (or a11) older relatives receive Ngoko. This is another point of tension in the speech level system which is reflected by variations in behavior.

Chart Three shows the three factors of speech level choice in terms of the speech levels which they elicit. The points of tension, where two factors conflict are indicated by alternative choices.

\subsubsection{Comparison of Javanese Speech Leve1 Meaning with the $T-V$ Variation of European Languages}

The factors which motivate speech level choice in Javanese are similar in type to those which motivate choice between the $T$ and $V$ forms of European languages (the ty-vy distinction of Russian, tu-vous of French, du-Sie of German, and so forth). However, the ethics of Javanese society which give these speech levels their meaning are surely quite different from those of European societies: in Java we see that the necessity for preserving. order (tôtô tentrem) is an underlying principle, and speech level usage is in the end motivated by this notion. Tôtô tentrem is something quite different in kind from notions of 'power' and 'solidarity' which Brown and Gillman see as motivating forces in $\mathrm{T}-\mathrm{V}$ choice.

On the other hand, there are points of similarity. Although status is differently motivated in Java and in Europe, in both places status is one of the two factors which lead to code choice. Similarly, although different factors lead to intimacy, in both Java and Europe intimacy is the sort of factor which determines code choice. For European societies Brown and Gillman talk, not about intimacy, but rather solidarity, which is based on things people have in common: things that make for like-mindedness, similar behavior, or similar disposition give rise to a feeling of solidarity. In Java intimacy is a matter of feeling at ease, or of not feeling strong pekéwoh toward one's interlocutor, a feeling which like-mindedness is not enough to bring about. (Javanese ethics take for granted like-mindedness and disposition and exhort absolute conformity in behavior.)

In terms of the pragmatics which elicit the code, $V$ forms in Europe are analogous to the $\mathrm{K}$ forms, and $\mathrm{T}$ forms to $\mathrm{N}$. The $\mathrm{M}$ level is in some ways analogous to $\mathrm{V}$ and in some ways analogous to $\mathrm{T}$.

In Brown and Gillman's analysis, the $V$ forms originally were signs of superior power, and from this they evolved into signs of membership in the upper classes. In the course of the past few generations the $V$ forms have taken on the notion of non-solidarity (not having much in common), and factors of power (Brown and Gillman's term 'semantic of power') have had less and less a role in motivating code choice, to the point that at the current time the non-solidarity factor is paramount, and there are only remnants of the factor of power which formerly motivated code choice. 
The $\mathrm{K}$ forms in Java denote status and non-intimacy, very much like the $\mathrm{V}$ forms in European languages. Further, we may say that in modern Java status is still the primary factor which gives rise to this code. In Java Krômô is given to people of priyayi class by anyone of lower class and by anyone of equal class who is not intimate. The usage is reminiscent of the usage of Eighteenth Century France where the haute bourgeoisie and nobility invariably received $V$. The factor of intimacy has not encroached on Krômô in Javanese in the way that solidarity has encroached on, and nearly replaced, the factor of power in the case of European V, and (as we shall see) cases of unbalanced relationships abound (where one party gives a high form and receives a lower form). In Java status assignation is demanded by the ethics of community, and the speech level system reflects this.

In Europe $T$ is the code of solidarity and in Java, Ngoko is the code of intimacy; but there is a difference. Whereas in Europe the situation has now developed where $T$ can be given to nearly anyone with whom one feels solidarity, in Javanese Ngoko cannot be given to all intimates. The ethics of proper placement demand that status be clearly assigned to intimates as well as non-intimates, and in Central Java status has so far usually won out over intimacy in eliciting code choice.

Madyô can be viewed as a half-way house: it is a code of intimacy used to a person to whom one cannot use Ngoko; it is a code of non-intimacy to interlocutors for whom Krômô is too high. Madyô is a status-according code where Krômô is too high. It is a status-withholding code for speakers with whom one might use Krômô. Most current European languages have no such half-way houses between $T$ and $V$ (although some of them seem to have developed such forms in the course of their history). ${ }^{1}$

\subsubsection{The Use of the Speech Levels}

Let us now take a look at the data from which we draw our conclusions.

We recorded around 450 pairs of speakers and persons addressed, i.e., close to 900 speech events ${ }^{2}$ on a certain speech level directed at an interlocutor. (We also recorded many speech events not directed at anyone in particular--Sec. 4.2ff.) of these directed speech events, we tabulated 393 palrs according to the level of speech employed and the relationship of the

1. This does not mean that European languages do not have ways of expressing gradations of solidarity and status. There are other devices available to all languages apart from the $\mathrm{T}-\mathrm{V}$ system. As Friederich points out in his quotation from Gogol (1972: 275), Russian was capable of the most refined class distinctions by means of terms of address. Similarly, Javanese has terms of address, honorifics, and other rhetorical devices in addition to the speech level system for expressing these gradations.

2. By the term SPEECH EVENT we mean the part a single person has in a conversation. A speech event may consist of as little as one sentence, or it may consist of a large number of sentences spoken in a conversation that endured over a considerable length of time. The number of different people recorded is a great deal less than the 900 speech events we discuss here, as many of the speakers were recorded on numerous occasions. 
speaker and the interlocutor. Chart Four shows the results of this tabulation.

In the chart, columns 2 and 3 show whether, in the judgment of the person who made the recording, the speaker or interlocutor are intimate ot not (i.e., know each other well). There is certainly plenty of room for differences of judgment on this point, and there are, of course, degrees of intimacy, all of which influence the precise speech level being used. Because of this, we did not try to correlate these figures with any other parameters. Columns 4 and 5 show whether or not the speakers were related, with column 4 indicating blood relationship to the first degree and relationships by marriage to members of one's immediate family. Columns 6-11 list speakers of the same generation, and columns 12-17 speakers of different generations. We generally classified all speakers whose age differential was less than ten years as of the same generation. Occasionally, however, there were indications (such as terms of address or terms of the second person) that persons closer in age regarded themselves as of different generations, or that people whose ages differed more widely regarded themselves as belonging to the same generation; and in those cases we classified them according to their own assessment. We divided our speakers into two classes: high and low. Anyone who had a white collar occupation (or the spouse or children of such a person) was included in the high class and the rest in the low. Such a broad division clearly does not distinguish the finer status gradations which speech level choices express, but once the speakers were roughly sorted out, we were dealing with a small number of cases in each category, and we could come to an understanding of inconsistencies or incongruencies in the figures by an inspection of the original data on which the figures were based. In the chart we list speech events among speakers of the same class separately from speech events among speakers of different classes.

In Chart Four there are $236 \mathrm{~N}$ speech events listed, including those addressed to people who answered in Bôsô. (We use the term Bôsô to refer to any speech level above Ngoko.) If we subtract the speech events of small children or adults speaking to small children we get $184 \mathrm{~N}$ speech events among adults. There are 354 Bôsô ( $K$ and $M$ ) speech events (of which twentytwo are from small children). Thus, in our sample of Javanese speech events, Bôsô makes up nearly two-thirds of the adult speech and more than half of all speech, if we count children's speech.

In depicting the factors of age, intimacy, and class which correlate with speech level choice (and which we have concluded determine it), the chart shows where these factors conflict with one another and which factor overrides in determining code choice. For example, in some cases the factor of intimacy overrides that of class in leading a person to choose between Ngoko and Bôsô. This is clear from the numerous cases where speakers in a social class manifestly inferior to that of their interlocutors, of the same generation, nevertheless use Ngoko. We have five examples of socially inferior speakers using Ngoko to their interlocutors (i.e., cases of people of differing class but of the same age and sex who exchange Ngoko mutually), and these are tabulated at the intersection of column 8 and row 22 . However, when looking at the individual cases from which these figures come, we see that all five involve people who have grown up together. Clearly intimacy is here the factor which leads to the choice of Ngoko over Bôsô. (For forty-eight other cases involving speakers of different classes but of the same sex and generation [i.e., those tabulated in column 8], one or, in most cases, both parties used a form of Bôsô.) 
Tabulation of Number of Speech Events Categorized by Intimacy, Generation, Sex, and Class

\begin{tabular}{|c|c|c|c|c|c|c|c|c|c|c|c|c|c|c|c|c|c|c|}
\hline & & & - & & & & sam & e ge & nera & tion & & & ffer & ent & gener & ratic & & \\
\hline & 1 & 2 & 3 & 4 & 5 & 6 & 7 & 8 & 9 & 10 & 11 & 12 & 13 & 14 & 15 & 16 & 17 & 18 \\
\hline Mutual Code & $\begin{array}{l}\text { total } \\
\text { speech } \\
\text { events }\end{array}$ & intimate & $\begin{array}{c}\text { not } \\
\text { intimate }\end{array}$ & related & $\begin{array}{c}\text { not } \\
\text { related }\end{array}$ & PP & WW & $\mathrm{PW}$ & PP & WW & $\mathrm{PW}$ & PP & WW & PW & PP & WW & PW & Unk \\
\hline 1. $\mathrm{K} \leftrightarrow \mathrm{K}$ & 80 & 23 & 57 & 1 & 79 & 24 & 0 & 10 & 7 & 0 & 1 & 18 & 0 & 4 & 10 & 0 & 3 & 2 \\
\hline 2. $\mathrm{K}, \mathrm{M} \leftrightarrow \mathrm{K}, \mathrm{M}$ & 1 & 1 & 0 & 0 & 1 & 1 & 0 & 0 & 0 & 0 & 0 & 0 & 0 & 0 & 0 & 0 & 0 & 0 \\
\hline 3. $\mathrm{K} \leftrightarrow \mathrm{MT}$ & 11 & 4 & 7 & 0 & 11 & 2 & 0 & 0 & 1 & 0 & 0 & 0 & 0 & 6 & 1 & 0 & 1 & 0 \\
\hline 4. $\mathrm{K}, \mathrm{N} \leftrightarrow \mathrm{K}$ & 3 & 0 & 3 & 0 & 3 & 0 & 0 & 0 & 0 & 0 & 0 & 3 & 0 & 0 & 0 & 0 & 0 & 0 \\
\hline 8. $\mathrm{K} \leftrightarrow \mathrm{N}$ & 7 & 5 & 2 & 2 & 5 & 0 & 0 & 2 & 0 & 0 & 1 & 2 & 0 & 2 & 0 & 0 & 0 & 0 \\
\hline 9. $K \leftrightarrow M$ & 3 & 0 & 3 & 0 & 3 & 0 & 0 & 0 & 0 & 0 & 0 & 1 & 0 & 1 & 1 & 0 & 0 & 0 \\
\hline 10. $\mathrm{MT} \leftrightarrow \mathrm{MT}$ & 18 & 5 & 13 & 1 & 17 & 2 & 0 & 6 & 1 & 0 & 0 & 1 & 1 & 3 & 1 & 0 & 2 & 1 \\
\hline 11. $\mathrm{MT} \leftrightarrow \mathrm{M}$ & 9 & 2 & 7 & 0 & 8 & 0 & 0 & 2 & 1 & 0 & 1 & 0 & 0 & 3 & 1 & 0 & 1 & 1 \\
\hline 12. $\mathrm{MT} \leftrightarrow \mathrm{M}, \mathrm{N}$ & 1 & 1 & 0 & 0 & 1 & 0 & 0 & 0 & 0 & 0 & 0 & 0 & 0 & 1 & 0 & 0 & 0 & 0 \\
\hline 13. $\mathrm{MT} \leftrightarrow \mathrm{MR}$ & 5 & 2 & 3 & 0 & 5 & 0 & 0 & 1 & 0 & 0 & 0 & 0 & 0 & 1 & 0 & 0 & 3 & 0 \\
\hline 14. $\mathrm{MT} \leftrightarrow \mathrm{N}$ & 6 & 5 & 1 & 2 & 1 & 0 & 1 & 0 & 1 & 0 & 0 & 3 & 0 & 1 & 0 & 1 & 0 & 0 \\
\hline 15. $M \leftrightarrow M$ & 53 & 24 & 29 & 0 & 53 & 4 & 3 & 23 & 0 & 0 & 5 & 3 & 2 & 7 & 1 & 0 & 5 & 0 \\
\hline
\end{tabular}


CHART FOUR (continued)

\begin{tabular}{|c|c|c|c|c|c|c|c|c|c|c|c|c|c|c|c|c|c|c|}
\hline & \multirow[b]{3}{*}{1} & \multirow[b]{3}{*}{2} & \multirow[b]{3}{*}{3} & \multirow[b]{3}{*}{4} & \multirow[b]{3}{*}{5} & \multicolumn{6}{|c|}{ same generation } & \multicolumn{6}{|c|}{ different generation } & \\
\hline & & & & & & \multicolumn{3}{|c|}{ same sex } & \multicolumn{3}{|c|}{$\begin{array}{l}\text { different } \\
\text { sex }\end{array}$} & \multicolumn{3}{|c|}{ same sex } & \multicolumn{3}{|c|}{$\begin{array}{c}\text { different } \\
\text { sex }\end{array}$} & \multirow[b]{2}{*}{18} \\
\hline & & & & & & 6 & 7 & 8 & 9 & 10 & 11 & 12 & 13 & 14 & 15 & 16 & 17 & \\
\hline Mutual Code & $\begin{array}{l}\text { total } \\
\text { speech } \\
\text { events }\end{array}$ & intimate & $\begin{array}{c}\text { not } \\
\text { intimate }\end{array}$ & related & $\begin{array}{c}\text { not } \\
\text { related }\end{array}$ & PP & WW & PW & PP & WW & PW & PP & WW & PW & PP & WW & PW & Unk \\
\hline 16. $\mathrm{M} \leftrightarrow \mathrm{MR}$ & 3 & 0 & 3 & 0 & 3 & 0 & 0 & 2 & 0 & 0 & 0 & 0 & 0 & 0 & 0 & 0 & 1 & 0 \\
\hline 17. $\mathrm{M} \leftrightarrow \mathrm{N}$ & 20 & $20(?)$ & $?$ & 5 & 15 & 0 & 0 & 0 & 2 & 0 & 0 & 6 & 1 & 6 & 1 & 1 & 3 & 0 \\
\hline 18. $\mathrm{M}, \mathrm{N} \leftrightarrow \mathrm{M}, \mathrm{N}$ & 1 & 0 & 1 & 0 & 1 & 1 & 0 & 0 & 0 & 0 & 0 & 0 & 0 & 0 & 0 & 0 & 0 & 0 \\
\hline 19. $\mathrm{MR} \leftrightarrow \mathrm{MR}$ & 15 & 14 & 1 & 1 & 14 & 2 & 0 & 1 & 1 & 0 & 1 & 0 & 2 & 4 & 0 & 2 & 2 & 0 \\
\hline 20. $M R \leftrightarrow N$ & 7 & 7 & 0 & 6 & 1 & 0 & 0 & 1 & 0 & 0 & 0 & 3 & 0 & 1 & 1 & 0 & 1 & 0 \\
\hline 21. $\mathrm{N}, \mathrm{M} \leftrightarrow \mathrm{M}$ & 3 & 2 & 1 & 1 & 2 & 0 & 0 & 0 & 0 & 0 & 0 & 0 & 1 & 0 & 0 & 0 & 2 & 0 \\
\hline 22. $N \leftrightarrow N$ & 196 & 195 & $1(?)$ & 59 & 136 & $67 *$ & 13 & 5 & 15 & 4 & 0 & 6 & 16 & 12 & 0 & 2 & 4 & 0 \\
\hline
\end{tabular}

* This figure does not include 52 speech events by children.

Abbreviations and symbols:

$X \leftrightarrow Y$ the speaker gives $X$ and receives $Y$ from his interlocutor

$X, Y$ the speech act vacillates between level $X$ and level $Y$

$\mathrm{K}$ Krômô

MT High Madyô

MR Low Madyô

M Madyô (not distinguished as to high or low)

N Ngoko

PP speaker and interlocutor are both priyayi

WW speaker and interlocutor are both non-priyayi (wông cileqq)

PW speaker and interlocutor are of different classes

Unk Unknown 
Another example where intimacy overrides social class in choice of Ngoko are the sixteen cases appearing in row 22 under columns 14 and 17, which represent people of different classes and different generations who exchange Ngoko. Now, normally when there is a difference of generation and social status, both parties, or at least one of the two parties, uses a form of Bôsô. (We have sixty-eight such cases.) However, in all these sixteen cases where a lower-ranking person addresses a person of high status with Ngoko, we find that the person who is lower in status is also older, and, further, that he has known the younger person since childhood. He regards himself very much as a parent. ${ }^{3}$

It was on the basis of these data that we were able to say ( 2.1 above) that intimacy is the factor which determines Ngoko--i.e., Ngoko is confined to speech between people who are intimate. There were only four cases where people used Ngoko to interlocutors with whom it was stated that they were not intimate. It seems likely that the judgment of the relationship in these four cases is an error on the part of the person who made the recording. In all likelihood, the perception of the recorder differed from that of the participants themselves with regard to the relationship between them. In other words, the person making the recording judged the participants not to be intimate, whereas the participants themselves thought of themselves as intimate.

We judged that intimacy alone is not enough to give rise to Ngoko because of the many cases in which people who are intimate use Bôsô. Sixteen of the Bôsô-N pairs involve close relationships--parent-child, elder sibling-younger sibling, etc., people who are intimate. ${ }^{4}$ In fact, close to one-third of the cases which show Bôsô on the part of at least one of the interlocutors involved people whom the recorder perceived as intimate.

The factors of status (class or age) override intimacy in these cases. In cases of speakers of different social classes, especially if there is a wide gap, the speaker of lower status often speaks up to his interlocutor (uses a higher speech level than his interlocutor), irrespective of age, even when the interlocutor may in fact be much younger than the speaker who is speaking up. (Cf. the cases in Sec. 2.1.2.1, below.)

If there is no social gap, age is the overriding semantic. Parents, teachers, old friends of the parents' generation may receive Krômô and give the children Ngoko throughout their lives. We have personally observed cases of elder siblings giving Ngoko to the younger siblings and receiving Krômô. (Unfortunately, we have not recorded this usage.) Very frequently within a family, throughout their lives elder members give Ngoko to and receive Madyô (or MT or MR) from members of the family who are younger than

3. Such a person, however, is not usually given the same respect as one's own parents. He is addressed as 'uncle' or 'aunt' léq 'parent's younger sibling' or wô 'parent's elder sibling'--depending on the addressee's age) and is given Ngoko, whereas parents were (at least until. the current generation) normally given Bôsô (Sec. 2.2.3).

4. If we define intimacy as being a matter of long-term association and security in the knowledge of status vis-à-vis one another, clearly blood relatives are normally intimate. The members of a family may engage in behavior which strikes us as distant, but they are in fact close and warm-even though the older party is using Ngoko and the younger, Bôsô. 
they are. However, this is a point of fluctuation. For some speakers family relationship overrides age, and Ngoko is exchanged.

\subsubsection{Cases of Unbalanced Exchanges}

We have many examples of speakers who use a higher speech level than they receive from their interlocutor. We call such usages 'unbalanced exchanges'. Unbalanced exchanges are of particular interest because they provide a key for understanding the type of factors which motivate speech level choice. If we look at Chart Four and tabulate the cases of unbalanced exchanges, we see that the speakers involved are of different status in all but two cases. That is, they are of different ages or considered different in class.

$\underline{\mathrm{K}} \rightarrow \mathrm{M}, \mathrm{MT}$, or MR. There are at least eighteen cases of speakers who use Krômô and receive various kinds of $M$ speech level in return. In our materials the only speakers who received Krômô in such cases were of the group we call priyayi. The speakers who receive Madyô are in most cases of the non-priyayi class or, if they are of the priyayi class, are still from some point of view lower in station than their interlocutors. In two cases we have examples of females of approximately the same class as their male interlocutors who give Krômô but receive High Madyô. There may be factors of class or age responsible for the unbalanced exchange which the commentator failed to note.

Bôsô $\leftrightarrow$ Ngoko. There are seven cases of speakers who use Krômô and receive Ngoko from their interlocutors, and thirty cases of speakers who use various levels of Madyo and receive Ngoko from their interlocutors. In the case of the $\mathrm{K} \leftrightarrow \mathrm{N}$ relationship all but two pairs are intimate and are of different generations. The $\mathrm{N}$ speaker who receives the Krômô is a parent or of the parents' generation and of high class. In the other two cases the $N$ speakers who receive Krômô are employers (or potential employers) of household servants.

The $\mathrm{N}$ speakers who receive Madyô (MT, MR) are in some cases related and of an older generation than their interlocutors (in some cases older siblings, and in other cases parents, aunts, grandparents). We have one example where a speaker, married to the older sister of the interlocutor, is treated as an elder brother (receiving Low Madyô and speaking Ngoko, just as his wife does), even though he is in fact younger than the interlocutor. In some cases, conversations consisting of a kind of Madyô reciprocated by Ngoko involve persons of different social class. If there is a wide difference in social class, this difference takes precedence over age, and the higher class speaker receives Madyô and gives Ngoko, and the lower receives Ngoko and gives Ngoko, irrespective of age. For example, a twenty-threeyear-old student uses Ngoko to an aged food purveyor and receives Low Madyô from her. Other examples: a middle-aged household servant uses Madyô to a medical student in the family, from whom the servant receives Ngoko; a prison official in his fifties uses Madyô to a college teacher in his thirties, from whom he receives Ngoko. If the social distance between the speakers is not great, unequal exchanges occur only when there is a generation gap: the older person uses Ngoko and receives Madyô from a younger. (In such cases the relations were described as intimate. The older person evidently looks upon himself as an older member of the interlocutor's family.) 
Madyô $\leftrightarrow$ Lower form of Madyô. In at least seventeen cases of speakers in a mutual Madyô relation, one interlocutor receives a clearly higher type of Madyô than he employs. These cases usually involve people who are in different social classes, the higher Madyô coming from the person of lower class. In a few cases a generational difference is involved, and the younger speakers employ a higher Madyo than they receive. In one case the two speakers are about the same age and of the same class, but the speaker who uses the higher level (MT) is trying to sell something to the interlocutor, who uses a lower Madyô (i.e., clearing ascribing status to his interlocutor as a subtle form of flattery).

\subsubsection{Balanced Relations}

$\underline{\mathrm{K}} \leftrightarrow \mathrm{K}$. In most cases where the speaker and interlocutor use Krômô, at least one, and usually both, of the pair is of priyayi class. If one speaker is of a lower class than the other but the gap is not great, mutual krômô may be exchanged. If the two are of equal class (and both priyayi), Krômô is only exchanged if there is some factor which serves to create distance (either a generational gap or lack of intimacy). Krômô may also be exchanged among intimate priyayi of the same generation, if they are of the opposite sex. We have two examples of men and women who are intimate exchanging Krômô. In both conversations the women involved are married, and their husbands also speak in the recorded texts. The men use Krômô with the women but Ngoko with the men.

MT $\leftrightarrow$ MT. Higher Madyô is mostly used in conversations which involve at least one non-priyayi speaker and usually among people who are not intimate. If they are intimate, there is an age gap. If there is a social gap the speaker of lower status is older than the interlocutor. In the five cases where High Madyô is exchanged by parties who were said to be priyayi, an examination of the actual backgrounds of the speakers reveals that at least one of them seems to be at pretty much the border of wông cilég ('small people') and was probably perceived to be so by his interlocutor. We have one example of mutual use of High Madyô among people of the same age who are related by marriage. 5

$M \leftrightarrow M$. Mutual ordinary Madyô $(M)$ occurs almost exclusively among people who are not intimate or speakers who are separated by class differences. Three of our cases of mutual Madyô involve no class differences and were said to be used by people of intimate relationship (but we doubt that the parties in fact are intimate, i.e., had attained a sufficient security to enable one of them to relax his attention to proprieties). ${ }^{6}$

5. They were characterized as being intimate, but we believe this to be an error. People of this relationship use Ngoko mutually or follow the usage of the spouse: if the wife (husband) uses Bôsô to her (his) elder sibling, the spouse follows suit, as in the situation discussed in the third subsection of Sec. 2.1.2.1 (Bôsô $\leftrightarrow$ Ngoko), where a husband follows the wife's usage, even though this leads to an unusual type of exchange.

6. In one case which involves one of our employees, a student is on $M$ terms with his younger sister's fiancé. He uses Ngoko to his sister. He and the fiancé exchange Madyô, because they do not know each other well enough to be secure in their mutual status, even though they are both students of the same age and are supposed to consider themselves brothers. They are both 
MR $\leftrightarrow$ MR. Our cases of mutual low Madyô involve, in all but one case, people who are intimate but somewhat (not greatly) separated by age or social status. The remaining case involves a woman of humble status and a student fifteen years her junior, who herself comes from a modest family.

$\mathrm{N} \leftrightarrow \mathrm{N}$. Mutual Ngoko is used by children (except for the cases discussed in Sec. 2.4) and otherwise almost exclusively by people who are intimate. It is rarely used by people who are not of the same social class (aside from children). The cases of people of different social classes using Ngoko are limited to people of different generations, when the older has known the younger since early childhood (and thus they are in a pseudo parent-child relationship) or people who have grown up together. Ngoko is exchanged in anger, where feelings of pekewoh are thrown to the winds.

\subsubsection{Personality Differences Which Affect Speech Level Choice}

There is a great deal of latitude in the choice of speech levels. One may regard one's interlocutor as much higher or much lower than oneself or one may close one's eyes to social distance. One may be more or less intimate with one's interlocutor. Thus, much depends on individual personality differences. Two employees of the same age and same status may use different codes with an office messenger also of the same age. Although knowing him equally well, one of them uses Madyô and receives Madyô (thus emphasizing the social distance), whereas the other uses and receives Ngoko (communicating his perception of the messenger as a white collar employee). Another example is found in the codes used by two town officials, both in their sixties, with a lesser official, twenty years their junior, with whom they are not intimate. The one uses Madyô and receives Madyô; the other uses Ngoko and-receives Madyô. Another example: a servant uses Madyô to a young doctor whose brother he addresses with Krômô. (The doctor is only one year younger than his brother, who has no education beyond secondary school.) He receives Ngoko from both. The doctor is quite unassuming and meek, whereas his older brother is quite stern and forbidding. Another example: a young man addresses one of his brother's menservants with Low Madyô and the other (of exactly the same age and same length of service) with Ngoko.

We note some generational differences too. Evidently the amount of Ngoko is increasing. We have no examples of children over twenty-one using Ngoko to their parents, but we have many examples of children below that age doing so. In a recording taken within the same family, the grandparents received Madyo from the parents; but from the grandchildren (who range up to twenty-one years old) they received only Ngoko, and the parents themselves also only receive Ngoko from their children. In some cases, when the children get older they may well decide to change to Bôsô. But certainly the number of cases which we have, and popular feeling, all point to the fact that there are generational differences.

from rural backgrounds, and we have found that students from rural origins tend not to be secure in relative position and give Bôsô to other students. City students, on the other hand, tend to have a greater assurance and behave intimately with nearly all their fellow students. This feature sets the type of Javanese used by students among themselves. In institutions or departments which tend to draw rural students, the students often exchange Bôsô. In those which draw primarily urban students, Ngoko is the norm. 


\subsection{Formal Features Which Define Each of the Speech Leve1s}

We here consider the speech levels in terms of the lexical items which make up the code. It is the lexical items which make up an utterance upon which we base our ascription of $\mathrm{N}, \mathrm{M}$ or $\mathrm{K}$ speech level. Other paralinguistic features or features of intonation, tempo, or rhetorical devices which also characterize $K$ speech are not considered in this study, although the use of Krômô means the use of these devices as well as the use of the lexical items which mark speech as Krômô.

It is usually possible to determine on purely formal counts the speech level which is being employed without paying close heed to the context or the contents of the utterances. The occurrence of certain forms and the absence of others clearly signal to the interlocutors (and to the analysts) which speech leve1 is being used. In List One Sec. 2.2.1 we give the forms of the highest frequency. This list shows that the first eleven items allow three choices according to three speech levels. The occurrence of any of these items will clearly indicate one of three speech levels. Since one or more of these eleven items is bound to appear in any Javanese utterance, the speech level is almost invariably signalled in an unequivocal way. For example, the form menikô 'that' clearly indicates that the utterance which contains it is Krômô. The form niku 'that' clearly indicates that the utterance which contains it is Madyô. The form iku 'that' clearly indicates that the utterance which contains it is Ngoko. Since the level is so clearly indicated to the analyst, we concluded that native speakers also recognize this. However, we have no come up with a reliable test.

What we have just stated implies restrictions of occurrence. Forms which are clear indicators of a $\mathrm{K}$ level (Sec. 2.1.2) do not normally cooccur with forms which are confined to the $M$ or $N$ levels. For example the prefix dipon- 'third person passive' (K) may occur together with sampon 'already' $(\mathrm{K})$ but not with the $M$ analogue mpon 'already' nor with the $\mathrm{N}$ analogue wés 'already'. Further, dipon- may be added to forms like tedhô 'eat' (K) but not to pangan 'eat' $(\mathrm{N})$. For example, the following sentences are normal Javanese (a11 meaning 'Already eaten'):

$$
\begin{aligned}
& \text { K: Sampon dipontedhô. } \\
& \text { M: Mpon ditedhô. } \\
& \text { M (lower): Mpon dipangan. } \\
& \text { N: Wés dipangan. }
\end{aligned}
$$

But the following sentences violate these restrictions of occurrence and are not normal:

*Mpon dipontedhô, or *Sampon ditedhô, or *Sampon dipangan, or *Wés ditedhô, or *Wés dipontedhô, etc.

If they occur, they are marked as containing a peculiarity of level usage, and we are quite sure the last three are types which never occur as part of one clause except as slips of the tongue, because the levels are too far apart to occur in one clause. Similarly $M$ forms which are required for even the lowest level of Madyô do not normally cooccur together with their $\mathrm{N}$ equivalents. For example, nôpô 'what' and niki 'this' occur only on the $M$ level, and ôpô and iki occur only on the $N$ level. Thus we get Niki nôpô, 'What's this?' (M) and Iki opô 'What's this?' (N), but not normally *Iki nôpô? or *Niki ôpô? We have qualified these statements by the word 'normally'. Code switches are a constant phenomenon in Javanese and occur in 
mid-sentence. (We discuss this phenomenon further in Sec. 4.4ff.) But the fact remains that there is a clear indication of shift in levels when these restrictions are violated.

\subsubsection{Determination of the Speech Levels}

How did we determine these speech levels? First, we took a portion of our materials and had native speakers assign a speech level to each utterance: K (Krômô), MT (for Madyô Tinggi, High Madyô), M (Madyô, not high or low), MR (for Madyô Rendah, Low Madyô), and N (Ngoko). We tested these identifications and received nearly 100 percent agreement on assignment into three categories, $K, M$, and $N$; but the MT, M, MR distinction was impossible to make consistently, as we ourselves had been unable to specify what the differences were. Thus, the informants distinguished the various kinds of Madyô impressionistically. However, it was possible for them to distinguish clearly relative levels of $M$ speech. For example, it was possible for them to identify consistently that utterances like those in the following examples which have been given the letter a are higher in level than utterances like those which have been given the letter $b$. Informants bore each other out consistently on this point.

1a. Kulô ngaten niku. 'That's what I said.'

1b. Kulô ngôten niku. 'That is what I said.'

2a. Mangké kulô betané. 'I will bring it later.'

2b. Mengké kulô gawané. 'I will bring it 1ater.'

Further, we had many utterances that we call 'faulty Krômô' (attempts at Krômô by a speaker who could not control Krômô). Informants who themselves could control Krômô consistently, recognized such utterances as faulty Krômô.

We thus were able to specify forms which occurred typically on each speech level. We found sixteen forms which occurred exclusively in utterances which informants had indicated as Krômô (List One A) and approximately twenty-five which occurred only in Madyo (from List one A, One B, and Two). We found some forms which were confined to Krômô and High Madyô, some which occurred only in some sort of Bôsô, and others which occurred only in Ngoko. The results of these findings are given in Lists one through Four. These lists contain by no means all of the forms which are Bôsô. A close to exhaustive listing of those in present-day use in Central Java is given in Soepomo 1968.

\section{2 .2 Krômô}

The $\mathrm{K}$ level is unequivocally signaled by the occurrence of certain forms which are confined to Krômô. There are at least fourteen such forms which are used almost exclusively in Krômô, and not at the lower levels (see List One A). They are the clearest indications of the $K$ level, since they are the most frequent forms in the language. If an utterance contains forms in the first column and in another column for any of the first fourteem items in List One $A$, we consider that there has been a code shift in mid-utterance (a switch from one code to another mid-utterance). The first five meanings of List $B$ also contain exclusively $K$ items, but for these meanings high Madyô (MT) forms also occur on the $\mathrm{K}$ level. A choice of high Madyô (MT) forms in these cases is considered to be a 'poorer' Krômô and speakers who are considered to have best control do not choose the $M$ forms for these items on the $\mathrm{K}$ level. 
High-Frequency Javanese Forms for Which the Krômô Level Form Substitutes for Forms That Are Different on All Other Levels

A

Forms which

1. -ipon/-nipon

2. -qaken/-qken

3. éngkang/engkang/ engkeng

4. menikô/meniô

5. saqmenikô/saqmeniô

6. menôpô

7. kémawôn

8. kaliyan/kaliyang

9. wônten

10. dhateng

11. sampon

12. sampon

13. takséh

14. badhé Forms which occur -é/-né

-qaké/-qké

sêng

niki, niku, nikô

saqniki

nôpô

mawôn/men

kalih

ônten/ènten

teng/ten

ampon/mpon/pon

ampon/mpon/pon

tasêh/tesēh

ajeng
C

Forms which occur in Low Madyô (MR)

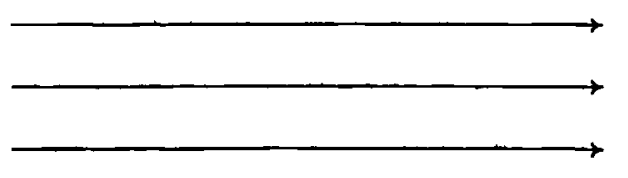

$i k i / k i y 1, i k u / k u w i, \quad$ ini, itu ikô/kaé
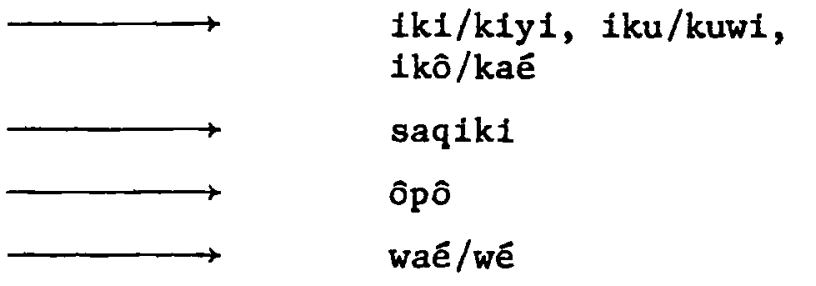

\section{waé/wé}

karo/ro/kambi, etc. ônô, ènèng

nang, etc.

wés/és

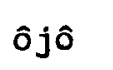

teséh

isēh/ijêh, etc.

arep

\begin{tabular}{c}
$\begin{array}{c}\text { Indonesian } \\
\text { translations }\end{array}$ \\
\hline
\end{tabular}

-nya

-kan

yang

sekarang now

apa

saja

dengan

ada

$k e, d i$

sudah

jangan

masih

mau 3rd person possessive verb former

linker

demonstrative

question particle

just

and, with

there is, are

to, at

already

don't

still

future maker

We do not include the numerous variants and the numerous synonyms which occur in Ngoko.

We do not list literary forms or form found in careful slow speech.

Slashes separate morphonemic alternants. 
LIST ONE B

High-Frequency Javanese Items for Which There Are Variants Used in Krômô and High Madyô but not Lower Levels

A

Krômô

1. mekaten/ngaten

2. inggëh/nggêh/njêh

3. piyambaqipon

4. piyambaq

5. dadôs

6. namong, naméng

7. menawi, yèn

8. lajeng

9. milô

10. suka-

11. kadôs

12. nedhô

13. mendhet

14. nedhô

15. wicanten, mungel, $\longrightarrow$ criyos

16. kajeng

17. dame1

B ngaten
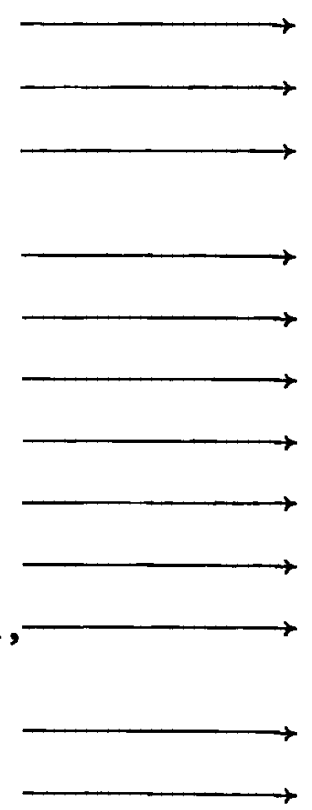

High Madyô

C

Madyô, Low Madyô ngèten, ngoten, ngôten

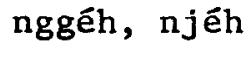

D

Ngoko

$E$ ngéné, ngono, begini, begitu ngônô

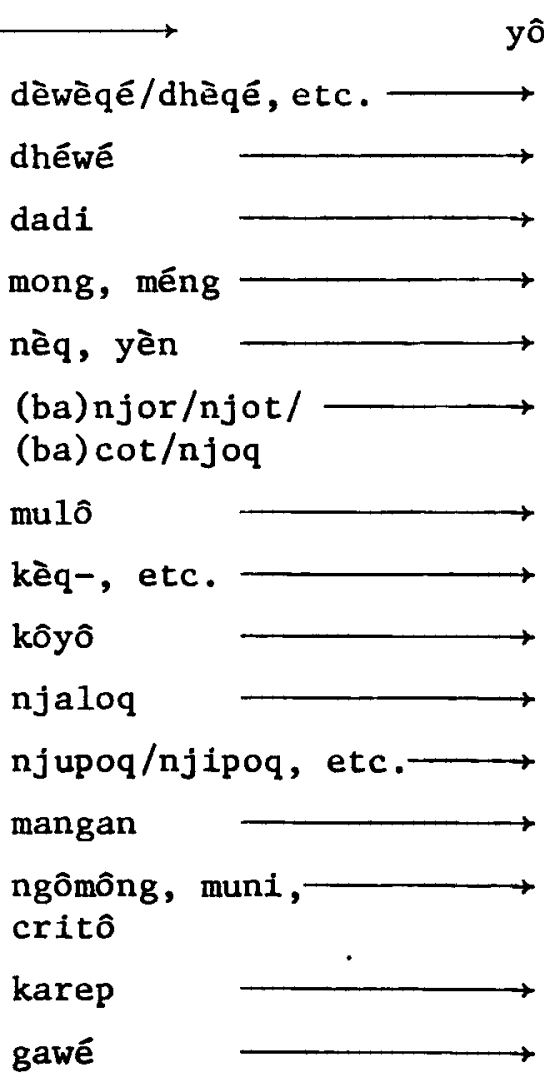

ya

dia

sendiri

jadi

hanya

kalau

lalu

maka

beri

seperti

minta, ambil

ambil

makan

bllang, berkata

hendak

bikin
F

Translation

thus

yes

he

most, alone

become

only

if

next

thus

give

as

get

take

eat

say, speak

wish

do, make 
LIST TWO

Items for Which There Are Special K, M, and $N$ Variants, and the $K$ Variant is Also Used In MT

A

$\underline{\mathrm{K} \text { and } \mathrm{MT}}$

kadôs (dôs) pundi

mangké

malêh

sanès

sakéng

panggènan
B

\section{$\underline{M}$ and $M R$}

(ke) pripon

mangké/mengké/ngké

malêh/meléh

sanès/senès/dédé/dudu

sakéng/sekéng/kéng

nggèn/nggôn
C

N

\section{(ke)priyé/piyé}

mengko/ngko

menéh

dudu/udu

sekô, sôkô

nggôn
D

Indonesian

bagaimana

nanti

$\operatorname{lagi}$

bukan

dari

tempat
E

\section{Translation}

how

later

again

not

from

place 
LIST THREE

Items for Which the $\mathrm{K}$ Variants are Used on the $M$ Level, but not on $N$

A

Madyô and Krômô

(m, ng)riki, riku, rikô

sinten

sawek/sek

pinten

mbôten

kulô
B

Ngoko

(m, ng) rẻné, rono, rônô kéné, kono, kônô

sôpô

lagi/agèq

pirô

ora

aku

\section{Indonesia}

(di, ke) sini, situ, sana

siapa

sedang, baru

berapa

tidak

saya (aku)
Translation

here, there

who

just now

how much

not

I 
LIST FOUR A

Items for Which the $\mathrm{K}$ Variants Are Used on Most $\mathrm{M}$ Levels but not Always in $M R$

A

MT and $K$ optiona1ly in MR

nggèn

kèn

dèrèng

gadhah

ngantôs

setunggal, kaléh, tigô, etc.

anggé(nggé), kanggé

laré

jaler

èsteri/setri

mantoq, wangso 1

kôlô
B

$\underline{M R, N}$

nggôn

kôn

durong/rong, etc.

nd uwé/ndé/nt hèq

nganti/ngantèq

siji/sitôq, loro, telu, etc.

nggo, kanggo

bocah

lanang

wêdoq

ba1i

ndhèq
C

Indonesian

tempat

suruh

belum

punya

sampai

satu, dua, tiga, etc.

pakai, untuk

anak

1aki-laki

perempuan

pulang

(none)

\section{Translation}

place

tell to do

not yet

have

up to

(numbers)

for

child

boy

girl

go home

(past time) 
LIST FOUR B

Partial List of Forms that Occur in $K, M$, and MT but not MR

Bôsô

mlebet

(ma) ngertôs

saé

mbēnj ang/mbénj éng

sônten, dalu

saged

ajrih

bektô/betô

tiyang

kanton

griyô

saé

mboq menawi

sanget

sémah

tingal

kinton

wastani

kathah

angsal

ageng

siyôs, èstu

ical

awés

sadé

sedhèrèq

padôs

sedôyô/sedanten

mlampah

(a) nggèn

saqèstu, 1eres/(ye)tôs

arto

mbajeng

tebéh

margi/mergi

celaq

langkông

telas

sekedhap

dinten

bènten

dandôsi

dangu

énggal

naté

cobi

suka
$\mathrm{N}, \mathrm{MR}$

melebu

ngerti

apéq

mbésoq

soré, bengi

isô

wedi

gôwô

wông

kari

omah

apéq/becéq

yaqé

banget

bojo

ndelôq

kirém

arani

okèh

olèh

gedhé

sidô, temtu

ilang

larang

adô 1

sedulor

golèq

kabèh

mlaku

olèh

bener/temen

dhuwit

mbarep

adôh

dalan

cedhaq

luwéh

entèq

sedhélô

dinô

bédô

dandani

suwé

anyar

tau

cobô

kèq
Meaning

go in

know

good

(future)

evening, night

can

afraid

bring

person

remain

house

well

perhaps

very

wife, husband

see

think, reckon

think s.t. to be

many

obtain

big

come into being

lose

expensive

se11

relation

look for

a11

walk

action of

actually

money

eldest child

far

road

near

most

done, used up

a minute

day

different

repair

long

new

ever

try

give 


\subsubsection{Madyô}

Speech which does not contain the forms which are obligatory for the $\mathrm{K}$ level but is nevertheless considered Bôsô is on the Madyô level. Madyô is marked by the occurrence of one or more non-Ngoko forms. Madyô is a continuum ranging from near Ngoko to near Krômô, but must always contain certain non-N forms. At the lowest level of Madyo--that is, at the $M$ level which is closest to Ngoko--some twenty items of our list will occur. If the utterance is in Madyô, the $M$ form for these twenty items will be chosen (and not the $\mathrm{N}$ form). The number of vocabulary items involved is considerably larger than the twenty items represented by the list, as on our list we have bunched related forms under one number (the deictics, the demonstratives, and others). To be specific, a non-N form is always chosen by speakers who use the M level for the following items: List One A: 4-11; List One B: 1, 2; List Two: all the forms, except possibly the items translated 'not'; List Three: all the forms.

But any time one uses Bôsô, even on the lowest $M$ level (MR), one may employ rhetorical devices which allow switches to Ngoko to create the feeling of an even lower level and greater intimacy, without abandoning Madyo entirely. The principal such device is non-directed speech (described fully in Sec. 4.2), which includes rhetorical devices such as direct quotation or talking to oneself. This non-directed speech is mostly in Ngoko (for one talks to oneself in Ngoko). Thus, a speaker who is obliged to speak Madyô, but needs to be more intimate than Madyô permits, may intersperse his speech with non-directed comments, broken every so of ten by $M$ forms like kulo ngôten niku 'that is what I said', or nggéh tô 'isn't that so?' and the like (Sec. 4.2.2).

Low Madyô can be raised by including more Bôsô forms. ${ }^{7}$ These forms are not all equal, and the choice of some of them implies a much higher type of Madyô than the choice of others. The first item of List One B, columns A, $B$, and $C$, mekatan, ngaten, and ngôten 'thus' all raise the speech level above Ngoko, but mekaten raises the level more than the other two; ngaten raises the level more than ngoten. Similarly forms in column A of List Two raise the level more than the forms in column $B$ of List One $A$ or the forms in column $A$ of Lists Three and Four. Choice of Bôsô forms in List Four B raises the level the most. But even the highest variety of Madyo which uses the Bôsô forms in List Four B may vary in level: some of the forms in List Four B raise the speech level more than others. We have included all the forms in one 1ist, equating them roughly, but in fact, some are more fancy than others. ${ }^{8}$

7. Low Madyô can also be raised by including honorifics (KI and KA). Theoretically, these honorifics should not change the level, but in actual usage they do. Increasing the number of $\mathrm{KI}$ and $\mathrm{KA}$ forms raises the degree of respect. We have examples of speakers trying very hard to ornament their speech by resorting to more than normal amounts of honorifics. See the discussion in Sec. 2.2.8, below.

8. It is possible to make a decision as to cooccurrence restrictions between forms on stylistic planes which are far apart, but for forms on planes which are only a short distance apart, we cannot make rules of cooccurrence restriction. For example, in English, most speakers would agree (and it could also be determined in some empirical way) that must is better (higher in 
At the $M$ level there is no hesitation about mixing within the same phrase forms which are confined to Bôsô and forms which are both Ngoko and Madyô. For example, the following citation shows $\mathrm{N}$ formd dhèg and kô (for kôô) together in a two-word phrase with $M$ forms (underlined):

A. Dhèq nôpô niku? 'When was it?'

B. Pancèn kô ngôten niku. 'That really is the way they do it.'

C. Lha patang ndinô berturotturot ki. (Answering A) 'It's been going on for four days in a row.'

Another example is the speech of a vendor to a small child, citation 6, Sec. 4.5, where we have ké séq 'just a minute' with ké $(M)$ and séq (N). The $M$ analogue on a slightly higher level would be mengké riyén; $N$ would be ko séq.

\section{2 .4 Ngoko}

This is the basic speech level. Any form which is not marked as Bôsô ( $K, M, K I$ or $K A$ ) is Ngoko. Most of the oldest forms in the language--i.e., forms which we can determine to be descended from a proto-language (ProtoAustronesian or a later proto-language) are in the $\mathrm{N}$ vocabulary. But not a1l $\mathrm{N}$ forms are old. Many $\mathrm{N}$ forms are forms which have recently entered Javanese. Some are Sanskrit borrowings (e.g., geni 'fire' from Sanskrit agni). We may speculate that such forms originated as Krômô but moved down into the $\mathrm{N}$ vocabulary. (But this speculation remains to be proven.)

\subsubsection{Substandard Krômô}

There is a substantial list of forms which are considered to be incorrect Bôsô forms, that is, forms which are used by speakers who do not know proper Bôsô. These forms are usually called Krômô Désô 'country Krômô' (KD). They are for the most part analogically created forms, such as $\mathrm{K}$ versions of proper names (which are not supposed to be made Krômô). For example, Kuthô Gedhé, a town south of Yogya, the name of which means 'big city' is made Krômô Kithô Ageng; Semarang is rendered Semawis, and so on. Some of the $\mathrm{KD}$ forms are hyper-Krômô. Sedôyô 'a11' (already K) becomes KD sedanten. In some cases there is no ascertainable historical reason for a given form to be Krômô Désô. It is just that certain $\mathrm{K}$ forms are avoided by speakers who best control Bôsô. For example proper speakers avoid kirangan 'I don't know' and kuwawi 'be able to do'. The proper $\mathrm{K}$ forms for these are, respectively, dukô (KA) or mbôten mangertôs (K) (and others), and kiyat. Historically, the $\mathrm{KD}$ forms have of ten moved up to respectability. Much of the $\mathrm{K}$ vocabulary consists of analogical creations which, in all probability, were originally regarded as substandard by correct speakers, although they are now considered good. In a few cases the older and new forms exist side by

style) than have to, which in turn is better than got to; further, we may say that procure is higher than purchase, which in turn is higher than buy and that get or get me are pretty close to the bottom. Clearly a form like *got to procure (meaning 'must buy') is peculiar and there is some sort of code shift involved in any sentence which contains this form. But it is difficult to say whether or not got to purchase (e.g., 'I simply got to purchase it today'?) is normal. Our categorizations do not go beyond the large differences of the type represented by our examples procure vs. get and got to vs. must. 
side as respectable forms: e.g., kôri and kônten (a later creation) 'door' are both considered correct (for $\mathrm{N}$ lawang).

There is at least one example of a substandard KI form: for wôjô, Krômô Inggil corresponding to $\mathrm{N}$ and $\mathrm{K}$ untu 'tooth'; there is the hyper- $\mathrm{KI}$ form waôs (under the influence of the wôcô 'read' (N), waôs 'read' $K$ and $K I$ ).

Faulty Krômô. Much of the population has little occasion to use Krômô or grew up in an environment where virtually the only form of Bôsô was Madyô with some Krômô Inggil. Such speakers are rarely in full control of Krômô, and when they try to speak Krômô they tend to slip into Madyô. (In some texts we find steady slippage and propping up.) We call this type of speech Faulty Krômô, and we regard utterances in Faulty Krômô as involving constant shift from Madyô to Krômô and back again. (We discuss this phenomenon further in Sec. 4.4.1.)

\subsubsection{Crude Forms}

There are some forms which are considered crude or coarse. They occur in slang or in utterances which reflect anger, but they are usually avoided. A number of these forms are listed in Soepomo 1968. Some of them were originally $\mathrm{N}$ forms for which the $\mathrm{K}$ analogues have also entered the $\mathrm{N}$ level. Examples are môtô 'eyes' (crude), mripat 'eyes' ( $N$ and $K$ ); ndhas 'head' (crude), sirah 'head' ( $N$ and $K$ ).

\subsubsection{Low-Class Speech as Reflected in the Use of the Speech Levels}

As we mentioned in Sec. 2.2.5 much of the community uses analogically created Bôsô forms which are not considered proper (called Krômô Désô). Such speakers also fail to control the $\mathrm{K}$ level. They are (aside from Peranakans, see Chapter 5) almost entirely from the peasant or landless laboring classes. But failure to control speech levels does not characterize all low-class speakers, many of whom have excellent control over Krômô. The reason that many low-class people do not control Krômô is that they do not use it, and a child from the lower classes may reach maturity having experienced Krômô only as a passive spectator. As krômô is used in the theatrical arts, to which everyone has access (especially the shadow plays), passive knowledge of it is universal. If a lower-class person speaks to a priyayi (gentleman or lady), Krômô must be employed, as anything less is perceived as improper to a priyayi's status. As all white collar workers are assigned priyayi status for the purpose of speech level usage, many occasions arise when people of the lower classes must address priyayi. On such occasions we find a constant rise and fall in speech level as a result of the attempt to put the utterance on the $\mathrm{K}$ level. The first two citations of Sec. 4.4 .1 below illustrate this shift from Krômô to Madyô back to Krômô.

Class differences are also reflected in the use of the honorifics. We frequently find examples of speakers trying to raise the level of their speech by resorting to more than the normal amounts of Krômô Inggil and Krômô Andhap--i.e., using $\mathrm{KI}$ and $\mathrm{KA}$ forms where they are inappropriate. These examples occur with speakers of humble class (or people whose origins are in such classes) who are trying to be on their best speech behavior. For example, in the quotation below the speaker asks if the maid has gone to the market. In doing so he uses the $\mathrm{KI}$ tindaq 'go'. The speaker is a student 
of humble social origins who feels that he must always be on his best behavior in the presence of the addressee (the American co-author of this paper):

1. Mbôq Yem sampon tindaq dhateng peken? 'Has Mboq Yem (the maid) gone to the market yet?'

A frequent error of this sort is the substitution of KI kagem 'for' in place of $\mathrm{K}$ kanggé:

2. Wadhah kagem gendhés. 'Container for sugar.'

Kagem 'for, used by' is normally only applied to persons who should be honored. When speaking of sugar the proper form is kanggé.

We also have examples of speakers who fail to use Krômô Inggil where it is proper. For example, a household servant tells how she was given a pendant by her former employer when she left her service. Her employer was an Italian lady whom she was supposed to respect highly, and properly she should have used KI diparingi ( $I$ was given). ${ }^{9}$ Instead she uses the $\mathrm{K}$ form:

3. Malah kulô disukani lyôntiné malaan. 'In fact, she even gave me her pendant.'

Low class speech is also revealed by use of local dialect forms at levels above Ngoko. In Ngoko it is all right to use forms of local currency, as Ngoko may well be in styles appropriate to intimate speech. But in levels above Ngoko, such forms are avoided except by speakers who are not aware that these forms are dialectical. An example is énjôh 'can' in the following utterance, which is on the $M$ level. The speaker is a vendor:

4. Pon, kulô ladèni. Kulô énjôh ngladèni. 'Let me serve you. I can serve you.'

Another example is on the MR level with nggôgi, a regional dialectical form for mènèi or ngekèqi 'give':

5. Mengké ndaq mong éntoq sambel, yô, ngèten niki. Pôlpôlé sambelé nggối gethog. 'If we do like this, all you will get is relish. I give as much relish as I can with the cassava cake.'

\subsubsection{Honorifics (Krômô Inggil and Krômô Andhap)}

The honorifics are used in addressing or talking about persons who are to be given honor (see the general description of honorifics in Sec. 1.2 above). The pragmatic factor which underlies the use of honorifics is status as defined by class and age. A person of priyayi class is referred to and addressed with honorifics if he is not inferior in age. Thus, children of priyayi class speak and refer to their elders with honorifics (whether they use $\mathbf{N}$ or Bôsô otherwise). Grown-up priyayi of the same age use honorifics to each other. It is of interest to note that priyayi wives normally use Krômô Inggil to their husbands, but husbands often do not do so in return. The use of the honorifics is a matter of degree: not all honorifics are

9. In this case the $\mathrm{K}$ form slips out because in fact the servant does not in reality respect her former employer. This example illustrates the fact that the speaker does not have the ability to hide her true feelings or does not keep to her proper place. The KI diparingi is of such high frequency, there is no doubt that the speaker has a feeling for its nuances. 
invariably used when honorifics are appropriate. We may divide the honorifics into four groups: (1) honorifics which are used if an honorific is appropriate at all; (2) honorifics which are frequently used but which are occasionally omitted where an honorific is appropriate (they imply a higher status than (1)); (3) honorifics which are confined to careful speech and imply a very high status; (4) rarely-used honorifics.

We give here a partial list of these forms, to each of which we have ascribed a classification on nothing more than an impressionistic basis. (Unless otherwise stated, the inflected and derived forms of these honorifics have the same grouping.)

Group 1: KI: kondor 'go home'; tindaq 'go'; paréng 'give, put' (and also in compounds, 'lend, sell, etc.'); pundhot 'take, bring, etc.'; dhahar 'eat'; unjog 'drink'; saré 'sleep'; rawoh 'come'; putrô, putri 'son, daughter' (putri in the meaning 'female' is less frequent); KA: kepareng (pareng) 'be allowed'; caôs 'give'; ator 'say'; suwon 'ask for' (most phrases with suwon are in group 2, however); sowan 'visit'; sugeng (in greetings); mônggô (particle of invitation).

Group 2: KI: siram 'bathe'; dalem 'house'; sédô 'die'; kersô 'desire'; kagungan 'possess'; pérsô 'know, see'; lenggah 'sit, live'; astô 'do, work, carry'; dhawoh 'order'; ngendikô 'say'; agem 'use'; dukô 'angry'; pinaraq 'stop in'; ampél 'get'; timbal 'call'; KA: dukô 'I don't know'; dalem 'I, yes (in response to sumons)'.

Group 3: body parts and personal appurtenances; priyayi (in N)/priyanton (in K) 'gentleman'; titéh 'ride'; wungu 'wake'; pidhanget 'hear'; amengameng 'visit'; muwon 'cry'.

Most of the rest of the honorific vocabulary is not common in ordinary conversations and is normally used only to address or refer to persons to whom particularly high status is assigned. These forms also appear commonly in literary styles.

In addition, a few forms of the $K$ vocabulary may be used as honorifics. That is, these $K$ forms appear in speech on the $M$ and $N$ levels to refer to (address or speak about) persons who are to be given honor. These are mostly (but not entirely) forms for which there is no KI analogue. Examples of a verb: waôs 'read'; of a noun: artô 'money'; of an auxiliary: saget 'can'. The $\mathrm{K}$ terms for parts of the body should be mentioned in connection with this usage. In the case of terms for parts of the body, in some cases the $N$ form is considered crude (Sec. 2.2.6), and $\mathrm{K}$ forms are substituted to avoid the rudeness. For terms of the parts of the body there are also KI forms which increase the honor of the person they refer to.

\subsection{Terms of Address and Titles and}

Their Relation to the Speech Levels

A large variety of titles and terms of address are in everyday use by the Pribumi Javanese. (In this chapter we do not discuss the terms of address used by Peranakans to each other, as they are entirely different. This matter is reserved for Chapter 5.)

Certain titles and terms of address imply that the status of the addressee is lower than that of the speaker, and the degree of familiarity is of the sort associated with the $\mathrm{N}$ speech level. These forms are found only 
with the $N$ speech level (Sec. 2.3.2 and 2.3.3). Certain other titles and terms of address imply a high status and the degree of deference associated with honorifics (2.3.3.6 and 2.3.3.7). Such terms are only found in speech with honorifics (but may occur with any speech level).

Otherwise the system of terms of address and titles operate independent$1 y$ of the speech levels and honorific systems and add a meaning component which is otherwise not expressed. For example, two teachers who have known each other for a long time and are close friends exchange Ngoko, but they indicate their mutual recognition of each other's position by addressing each other as penjenengan 'you (honorific)' and using honorifics with one another. Mutatis mutandis, one can still show affection with terms of address even though caste or status differences require the use of Krômô. For example, a son, who addresses his father in Krômô, makes frequent use of the term of address paq and uses the term of address bapaq 'father' as well as penjenengan to show his intimate and affectionate relationship. Similarly a nursemaid may use Krômô to a high-status child in her care, but also use terms of endearment (as well as a cooing tone of voice) to express her intimacy.

\subsubsection{Titles and Vocatives}

Titles are terms such as English 'Mr.' which appear before proper names, e.g., Mas 'elder brother' in the name Mas Tônô 'Mr. Tono' is a title. Most of the titles originate as terms of relationship, but they are extended to unrelated addressees. A vocative is a title, a name, or a title followed by a name used in addressing someone. For example, in the following sentences, Mas, Mas Tônô, and Tônô respectively are vocátives:

a. Wés, Mas. 'Good-bye, friend.'

b. Wês, Mas Tônô. 'Good-bye, Mr. Tono.'

c. Wês, Tônô. 'Good-bye, Tono.'

The use of a name without a title is called njangkar. An example of njangkar is sentence $c$, above. Njangkar is confined to familiars, as described in Sec. 2.3.2. It is found for the most part with the $\mathrm{N}$ level. Otherwise, every title and every vocative is found on every speech level and with varieties of the terms of address (words for 'you'). Most of the titles and vocatives refer to relationship. Charts Five A, B, and $C$ show the terms which occur in our materials. (Others exist, but we did not happen to record them.) All of these forms occur both as titles and by themselves as vocatives.

These terms refer to kinship relation. They are, however, not necessarily confined to kin, but are widely extended to people of the right age to have such a kinship relation to the speaker. ${ }^{10}$ For this reason the terms

10. There are exceptions. The terms paqé, buqé, mbôqé usually are reserved for one's parents. Further paq and bu (mbôq) are frequently applied to people younger than the speaker: (1) to the husband or wife of the family or parents of other people's children and (2) to people in certain occupations (for example, teachers). Paq plus a name or for women Bu plus her husband's name are used like English $\overline{\mathrm{Mr}}$. and Mrs. Furthermore, these titles are freely used in the process called mbasaqké, where a person is referred to not by the title which the speaker normally gives the person referred to but by the 
of address have no connection with the speech level. Other terms of address (most of which are not usually followed by the name) are terms which refer to occupations, terms of endearment, terms derived from noble titles, and terms from foreign languages originally used as titles to foreigners: e.g., dukué 'village head', lurah 'town head', dhokter 'doctor', etc. The following charts show other titles which occur in our texts:

CHART FIVE A

Titles Given to

\begin{tabular}{|c|c|c|}
\hline Relationship & Males & Females \\
\hline grandparent & mbah & mbah \\
\hline parent & $\frac{\text { paq (bapaq) }}{\text { (bapaqé) }}$ paqé & $\begin{array}{l}\text { high class: bu (ibu), } \\
\text { buqé (ibuqé) } \\
\text { low class: mbôq, mbôqné }\end{array}$ \\
\hline children & naq (anaq) & naq (anaq) \\
\hline elder sib1ing & $\begin{array}{l}\text { high class: mas, } \\
\text { kangmas }\end{array}$ & $\begin{array}{l}\text { high class: mbaq } \\
\text { (mbaqyu) }\end{array}$ \\
\hline $\begin{array}{l}\text { sibling (younger or } \\
\text { older) }\end{array}$ & none & high class: jeng \\
\hline younger sibling & $\frac{\text { dhimas, }}{\text { dhèq }}, \underline{\text { dhéq (adhèq) }}$ & $\frac{\text { dhiajeng, dhéq (adhéq, }}{\text { dhèq, adhèq) }}$ \\
\hline $\begin{array}{l}\text { parent's elder } \\
\text { sibling }\end{array}$ & $\begin{array}{l}\frac{\text { paq dhé (from bapaq }}{\text { gedhé) }} \\
\text { low class: wô }\end{array}$ & $\begin{array}{l}\text { high class: bu dhé } \\
\text { (from ibu gedhé) } \\
\text { low class: mbôq dhé, wô }\end{array}$ \\
\hline $\begin{array}{l}\text { parent's younger } \\
\text { sibling }\end{array}$ & $\frac{\text { bapaq léq, paq léq }}{\text { (from bapaq ciléq) }}$ & $\begin{array}{l}\frac{\text { léq, bu léq (from ibu }}{\text { ciléq) }} \\
\text { low class: mbôq léq }\end{array}$ \\
\hline
\end{tabular}

title which the interlocutor normally gives the person referred to. E.g., a parent refers to a child's elder brother as Mas [so-and-so] when speaking to a child, as a sign that child should address and refer to his brother as Mas. 
CHART FIVE B

Terms of Endearment for Children

\begin{tabular}{|c|c|c|}
\hline & Boys & Gir1s \\
\hline strong endearment & nggèr & nggèr \\
\hline neutral & $\frac{1 e ́}{\text { kônthôlé) }}$ & ndhog (gendhog) \\
\hline endearing & $\begin{array}{l}\text { gos (from bagos) } \\
\text { cah bagos }\end{array}$ & nôq (dhénôq) \\
\hline
\end{tabular}

CHART FIVE C

Titles Given to People Who are Unrelated*

\begin{tabular}{|l|l|l|}
\hline & \multicolumn{1}{|c|}{ Male } & \multicolumn{1}{c|}{ Female } \\
\hline $\begin{array}{l}\text { derived from a title of } \\
\text { nobility (to adults or } \\
\text { children) }\end{array}$ & dên, ndôrồ & dèn \\
\hline $\begin{array}{l}\text { friendly, irrespective } \\
\text { of rank (to adults only) }\end{array}$ & om & tante \\
\hline $\begin{array}{l}\text { formal, distant and } \\
\text { respectful }\end{array}$ & tuwan & $\begin{array}{l}\text { nyonya } \\
\text { unmarried woman: nôn } \\
\text { (nôna) }\end{array}$ \\
\hline to Chinese adults & $\underline{\text { bah (babah) }}$ & nyah (nyônya) \\
\hline
\end{tabular}

* The title of this chart is somewhat misleading: dèn, om and tante are occasionally addressed to relatives, especially om and tante, which originate from the Dutch words for 'uncle' and 'aunt'. Further, dèn and ndorô (and some other terms not in our materials) may be addressed to anyone as a means of currying favor. They are commonly used by beggars, market vendors, and the like when they wish to part the addressee with some money. Tuwan and ngonya do not have the equal rank connotation. Tuwan (sir) is used only to persons of high rank, whereas nyonya (ma'am) may be used for a high- or just medium-ranking woman. Also nyonya implies less formality and distance than tuwan. 


\subsubsection{Njangkar}

Njangkar (use of name without title) is confined to cases where the speaker does not wish to show special respect. For the most part njangkar is engaged in by speakers who are on $\mathrm{N}$ terms with their interlocutors and who address them with no honorifics. The term of address is either the avoidance pattern (2.3.3.1) or kowé (2.3.3.2). In a few isolated cases we find servants speaking to people young enough to be their children in Madyô, but still addressing them by name without title. We also have examples of young people speaking to inferiors in Madyô but using the name without title.

\subsubsection{Terms for 'You'}

\subsubsection{The Avoidance Pattern}

In the vast majority of our conversations we find no term of direct address at all--i.e., no word for 'you'. It is usually possible to frame a sentence in such a way that the word for 'you' is omitted (but cf. 2.3.3.2). From the context it is usually clear who is being referred to, especially if there are honorifics in the sentence. We call this usage the avoidance pattern. For example in a sentence such as the following, there is no work 'your', but it is clear from the use of the KI putrane' 'the children' that the talk is about the addressee's children:

1. Putrané raq loro tô / the-children two isn't-it-so? / 'You have two children, don't you?' (Slashes give a word-by-word translation here.)

A commonly used greeting is the following, where it is clear that tindag 'go (KI)' must refer to the addressee:

2. Tindaq saking pundi (N: tindaq sekô ndi?) / go from where / 'Where are you coming from?'

This usage gives rise to the KI forms keng plus term of relation which mean 'your wife, husband, father, etc.' (short for éngkang [so-and-so] 'the one who is'), e.g., keng rôkô 'your husband' (1it. 'the one who is the elder brother'), keng bapaq 'your father', etc. For example, in the following citation a vendor indirectly tells her interlocutor that the wife of a mutual acquaintance bought a large number of goods for a high price:

3. Kulô raq mator Dhéq Maksô, "Kulô wau nuthoq keng rayi." 'You know I just said to Maksô, "I made a killing at your wife's expense."'

If a term of address is used, the relationship between the speaker and hearer becomes much more overt than with the avoidance pattern. That is, the term of address emphasizes the intimacy or distance of a relationship. For example, in the following sentence the fact that the addressee is regarded with great respect is made overt by the use of penjenengan 'you (KI)':

2a. Penjenengan tindaq sakéng pundi? 'Where are you coming from?'

On the other hand the use of kowe 'you (N)' brings out overtly the fact that the addressee is a child or very intimate with the speaker:

2b. Kowé sekô ndi? 'Where have you been?' 
In sentences which follow the avoidance pattern, a title or the name is of ten used as a vocative:

2c. Tindaq sakéng pundi, Paq? 'Where are you coming from, Father?'

\subsubsection{Kono}

In speech which uses Ngoko and the avoidance pattern, the form kono 'there, near you' is used as a term for 'you' where the construction requires a term for the second person. (At higher levels, such constructions have to be avoided, or one of the higher terms for 'you' is used--2.3.3.4, 2.3.3.5, or 2.3.3.6.) E.g., in the following sequence a word for 'you' cannot be avoided, so kono is used in order to avoid kowé (which would be too low), or any of the other terms for 'you' (which would be too high):

"Sôpô kôndhô?" -- "Kono." '"Who said?" -- "You did."'

\subsubsection{Kowé}

Kowé is a term of address which clearly signals one of two things: great intimacy or positive disrespect. First, if it signifies intimacy: the person addressed as kowe is almost always of the same generation or younger, and of the same social class or lower than the speaker. Most of our examples of kowe are addressed to relations or people with whom the speaker has been acquainted since childhood. Some are certainly people who have become intimate later in life, but the relationship is as intimate as if they had known each other since childhood. Second, kowé may be a sign of disrespect. It is disrespectful to use kowe to a person older than the speaker or not of a close intimacy. Our example of kowe as a sign of disrespect if from the speech of a prostitute who uses kowé to a policeman, twenty years her senior.

Even in conversations where a person is addressed as kowé, we frequently find the avoidance pattern with regard to the same addressee. Kowe is used to persons who are given Ngoko without honorifics, but not all persons who are given Ngoko without honorifics are addressed as kowé. Kowé occurs in our materials as a term of address to people who are also given the titles referring to relationship listed in Sec. 2.3.1 above, except those of a higher generation or jeng.

\subsubsection{A Title or a Title plus a Name as a Term of Address}

The use of a title or title plus name for 'you' is a sign of respect and the addressee is also addressed with honorifics and is spoken to on $\mathrm{K}$ or $M$ level. The speaker in every case in which this usage occurred in our materials was said to be intimate with the interlocutor. We also have examples of bapag 'father', ibu 'mother' and simbah 'grandfather, grandmother' used as a term of address by the children or grandchildren who use Ngoko together with honorifics to their elders.

\subsubsection{Sampéyan}

Somewhat similar in feeling to the use of a title or name plus title as a term of address is the use of sampéyan (or its short forms: sampan, samang, mang, et a1.). Sampéyan is most frequently used to people whom one addresses in Madyô and with whom one is not intimate, although we have examples of mang 
as an agent of the passive verb addressed to people with whom one is intimate but with whom one uses Madyô, e.g., a son to his mother. We have only one example of sampéyan in Ngoko, but it occurs in a comedy skit and is probably influenced by East Java usage (where sampéyan occurs on all levels). 11 We have one case of a speaker trying to speak Krômô (speaking faulty Krômô) and addressing his interlocutor with sampéyan, and several cases of speakers using Krômô and switching back and forth from sampéyan to penjenengan. We have only one example of njangkar (use of name without a title) to a person who is addressed as sampêyan.

\subsubsection{Penjenengan}

Penjenengan (short form: njenengan; very formal: panjenengan) is considered an honorific form of direct address and is usually accompanied by other KI and KA forms to refer to the addressee. It occurs on all speech levels (as can all honorifics), but most of our examples are with High Madyô or Krômô.

The term penjenengan may be addressed to intimates or to people whom one does not know. For example, we have the recording of a son who gives his father Madyô, addresses him as penjenengan and calls him paq 'Dad'. In another case a son uses Krômô and penjenengan to his father. Typically, Ngoko and penjenengan as the term for 'you' are used by speakers who are of the same social class as the addressees (high or low) and of the same generation--i.e., they are on a $\mathrm{N}$ basis because they have worked together, or for some other reason are on a $\mathrm{N}$ basis (e.g., married to each other), and there are no barriers of age or sex which would lead to the employment of Krômô or Madyô. We have cases of switching from penjenengan to some other term of address. These all involve cases where the one speaker is lower than the addressee from some point of view (e.g., social position) but much higher from other points of view (e.g., age).

\subsubsection{Other Terms of Address}

There are other terms of address, but the only one that has turned up in our materials outside of recordings of dramatic performances is sliramu or keng slirô, which is said to be an honorific, as penjenengan is (i.e., occurs on all levels), but clearly indicates that the addressee is substantially younger than the speaker. In the two instances where it occurs in our materials the speaker is a generation older than the addressee. In one, the speaker is distantly related to the addressee and uses Ngoko with honorifics, and in the other the speaker is unrelated to the addressee, not intimate, and uses Krômô.

\subsubsection{Forms of the First Person}

The first person kulô usually is employed for all levels above Ngoko. ${ }^{12}$ We have a few examples of dalem 'I', which is Krômô Andhap (confers honor on

11. In East Java, sampéyan is used with all speech levels and functions as an honorific very much as penjenengan does, though giving somewhat less honor. To speakers from Central Java the use of sampeyan on any but the $M$ level sounds peculiar.

12. There is an exception to the statement that kulo is used at all levels 
the addressee) as opposed to the neutral kulô; but in the meaning ' $I$ ', it is not normal Central Java usage (though common in East Java). In Central Java it is used only in literature and dramatic performances, or in humor, or on part of speakers who wish to ingratiate themselves with their interlocutors. (However dalem as a response to being called is frequent everywhere.) In Ngoko aku (or its inflected forms) is generally used uninhibitedly. We have some examples of kéné 'here' used as a way to avoid aku on the $N$ level, but we find that even speakers who refer to themselves as kéné also use aku in the same conversation with the same interlocutor. We also have examples of speakers who use a name plus title to refer to themselves. In these cases the feeling is one of endearment and the stress is on the family relationship (or pseudo-relationship) of the speaker with the interlocutor. Referring to oneself by name or title occurs with all speech levels.

1. Saqniki Mbôq Yem teng peken. (Maid to employer) 'I (1it. Mother) am going to the market now.'

2. Lho titépnô budhé. ôjô kuwatér. Tenan kôq naq. Lho, iki jenengé pengalaman budhé ki wisan. 'You just leave it with your old auntie. Don't worry. Rea1ly, son. Your aunt is what they call an old hand at this sort of thing.'

Small children of ten refer to themselves by their proper names.

\subsection{Speech Level and Honorifics in Children's Speech}

The normal speech level used to and by children is Ngoko. They are, however, supposed to use Bôsô to their elders and superiors just like everyone else, and we note in our tapes that they do, to some extent, control these forms. Our tapes show that the development of the $M$ speech level forms and their proper use proceeds by stages, just as the development of the morphology and syntax does, and there is no reason to believe that the $M$ speech level forms come any later than complexities of the grammar. Although we have no extensive tapes nor in-depth records of individual children as they learn language, which would enable us to state precisely how grammatical or speech-level forms are acquired (all we have are chance recordings of children from thirty months and older), our recordings of small children of only thirty months show a clear control of individual M forms (e.g., citation 4, below). We have utterances from children five and above which show an ability to sustain Madyô for some time and self-correct forms of the wrong speech level (citation 5). We have extensive utterances from children of eight which show a complete control over Madyô and an ability to shift back and forth from Madyô to Ngoko in much the same way as adults do (citation 1).

These statements are made about Madyô, rather than Krômô, because we have no recorded example of children speaking Krômô. We have personally observed children who use krômô, but without a recording it is impossible to say to what extent they control its vocabulary. The $\mathrm{K}$ vocabulary involves far many more forms than Madyô: it is possible to speak a Madyô with only a handful of Bôsô choices, but proper Krômô involves hundreds of common items,

above Ngoko in the case of a speaker who uses taq, the $\mathrm{N}$ first person passive affix, in place of kulo in Low M speech. This is an isolated example in our materials, but we have occasionally heard it in conversations not recorded. 
so that one would expect a priori that small children could hand le only a portion of the $\mathrm{K}$ vocabulary; but, without recordings, we cannot confirm this.

As for honorifics, we have no examples which prove conclusively that children control these forms. What we have is examples which show that children of all ages using the most common KI and KA forms, of ten correctly; but perhaps these correct choices are accidental or confined to a few set phrases. In our examples of the speech of children under ten there are enough errors (failures to use Krômô Inggil or Krômô Andhap where they belong, of using KI or KA forms in place of Krômô) for us to doubt that children under ten are able to control these forms.

An example of children who have control of the $M$ level comes from the recording of a game of buying and selling the market. (The Bôsô forms are underlined.)

1. 5-year old: (pretending to buy from his sister) Lha rujaqé nduwé ra, mas? 'Do you have any vegetable salad?'

8-year old sister: (taking the role of a vendor) 0 , rujaqé niku dèrèng tekô. 'The vegetable salad hasn't been delivered yet.' 5-year old: (switching to M) O nggêh tô? 'Oh, is that so?' 8-year old: Njéng énjéng séng tekô. Njéng énjéng tenan. Nèq kulô mriki. Nèq kulô mbôten mriki, mbôten. 'It will come tomorrow morning. Really, tomorrow morning. That is if I come here. If I don't, they won't deliver it.'

How do children learn these forms? The fact is that, although Ngoko is the normal level given to children, they are not consistently addressed in Ngoko. Their elders (including elder siblings) tend to switch frequently to Madyô. For example, a mother coaching her thirty-month old child to speak for the audience (the person who made the recording) uses Madyô and honorific forms (underlined twice):

2. Mother: Nggé mundhot rôk kaléh nggéh mundhot nôpô? 'To buy a dress and . . what else do you want to buy?'

Child: Nggé mundhot mbanggulô. 'I also will buy candy.' Mother: Mbanggulô? 'Candy?'

Child: Nggêh. Mbanggulôné caôské Bapaq. 'Yes. Candy to give to Father.'

This example shows the child choosing the proper form of the verb 'give', proper not only from the point of view of correct affix choice, but also from the point of view of choosing the $\mathrm{KA}$ rather than the $\mathrm{KI}, \mathrm{K}$, or $\mathrm{N}$ root.

Elders teach the child to address older people with honorifics by using honorifics to refer to themselves. This usage is called ngajari bôsô or marahi bôsô 'teach Bôsô'. That is the only occasion in our materials on which we have examples of a speaker using honorifics to refer to himself. ${ }^{13}$

13. It is absolutely prohibited in Central Java to use Krômô Inggil to refer to oneself, and most speakers seem to control the $\mathrm{KI}$ and $\mathrm{KA}$ forms well enough to avoid doing so. It would be putting oneself on a pedestal (failing to feel andhap asôr). However, in East Java it is almost normal for low class speakers to use Krômô Inggil to refer to themselves. For such speakers, Krômô Inggil is merely a more elaborate or higher form of Krômô and does not function as a set of honorifics at all. 
In the following example a father uses $\mathrm{KI}$ paringi 'give' to refer to himself in speaking to his little daughter:

3. Nyhôh. Taq paringi nèh. Paringi gambar. Nyôh, ki, naq, Ana . 'Here, I'll give you another one. I'll give you a picture. Here, over here, honey, Ana.'

An example of Madyô and Krômô Andhap in a situation of natural conversation comes in the speech of the same father as in citation 3 with his two children (the youngest being aged around twenty-four months). The father uses KA dalem 'yes' (in answering to a call) as a way of teaching the child to use the form. He also uses $K, M$ mboten 'no' which is interrupted by the big brother's ora he first time, but the second time, it is imitated as mbôten. Later on, the child by herself comes out with $M$ enggéh 'yes' without being coached, but only has $\mathrm{N}$ ora 'no' in the same sentence.

4. Child: Bapaq. Paqé. Paq. 'Daddy!'

Father: Dalem. Ngômpôl mbôten, Ana? 'Yes, ma'am! Did you wet your pants, Anna?'

Big brother: Oraq kôq. 'She did not.'

Child: Oraq kôq. Ora. 'I did not. I didn't.'

(later)

Child: Gandhol ayo. Gandhulan, ayo. 'Swing, swing me.'

Big brother: Wo. Kô ngono kuwi. 'Why are you doing it like that?'

Father: Nèq dhawah. 'If you fall.' (Making signs to take her off.)

Child: Ora paq. Enggêh, paq. 'No. I don't want down. Yes, I do.'

Father: Ha yhô. Medhon. 'OK. Get down.'

Children are taught to use Bôsô in the first couple of years of school. A recording we made in a kindergarten class of five-year-olds shows the children with a fairly extensive $K$ and $K I$ vocabulary. But there are numerous slips. In the following citation Child 1 corrects herself from $\mathrm{N}$ mbiyèn to $M$ riyen. She uses the KI kondor incorrectly to refer to herself. (She was looking for a $M$ term meaning to 'go home' but used the KI kondor instead of the $M$ term wangsul). Child 2 uses $K A$ ndhèrèg correctly but later uses kaé 'that', a form inadmissible on the M level:

5. Child 1: Dhèq mbiyèn, riyén kulô teng Jakarta . . . teng, ten . . . $\mathrm{Ja}$. . . sekatènan két mbengi lé kondor, nganu, ésoq.

'The other day I was at, was at Jakarta during the time of the sekatèn ceremony. I left at night and I did not get home until, umm, morning.

Child 2: Ha nèq kulô, nggéh ndhèrèq, ibu. Dadi mau kaé mbôten bocah. 'I also went along, teacher. [Referring to a story which had been told previous to this conversation] So that was not a child!' 
CHAPTER 3

THE FUNCTION OF INDONESIAN

\subsection{Introduction}

For the Javanese of Central Java, as for groups throughout Indonesia, Indonesian is the official language, and it is used for the kinds of functions which official languages commonly fulfill: in schools above the elementary level; for any activities involving the government (courts, military, public health, agricultural extension, etc.); for national mass media, advertising, and the like; and other such activities which are carried out on a national scale. Indonesian is the language of business above the bazaar level and is the language of communication with non-Javanese. It thus also had the function of creating distance and clarifying the outsider's status as an outsider, and the tendency is to use Indonesian with any non-Javanese, even with those who know Javanese. (See the example in Sec. 3.6, below.)

Indonesian is typically used for prestigeful activities, and in using Indonesian people get the kind of prestige they would from engaging in these activities. Thus, Indonesian is a code which confers a certain sort of prestige. For example, Indonesian is associated with education and modernization. A well-educated person is fluent in Indonesian, as is a modern person. Therefore, fluency in Indonesian gives one the aura of being educated and modern. Indonesian is also the language of Jakarta, the capital city, and as such is associated with people who have gone places in the world, especially the elite (most of whom live in the capital or spend time there). It is the language of government, and people who have political power use it. Thus, Indonesian is associated with the exercise of political power and as such acquires a sort of prestige.

On account of these factors, Indonesian has become an important code among Javanese: it is used not only to communicate with non-Javanese or to talk about subjects for which Javanese is normally not used, but it is also a device for asserting for oneself the status or right to prestige which is ascribed to speakers of Indonesian.

Finally, Indonesian has a function of an entirely different sort. Since it is so widely known, it can serve as a device for avoiding use of Javanese in a social situation where it would be awkward whichever the level chosen. (We shall exemplify these situations later, Sec. 3.4.1.)

3.1.1 Forms of Indonesian Used by Javanese Speakers to Other Javanese Speakers

Indonesian can take three different forms in a conversation which involves Javanese speakers. 
First, loan words can be adopted, or Indonesian phrases interspersed in what is essentially a Javanese discourse. These phrases are usually for topics where the Javanese forms are not as well known as the Indonesian. This borrowing differs from usual descriptions of borrowing in other languages in that the use of Indonesian forms influences the forms around them, to such an extent that a great part of the sentence becomes Indonesian. It is possible for Indonesian forms to influence Javanese forms surrounding them because of the parallelism between the grammatical structures of the two languages. We exemplify this process in a conversation between two nurses who speak Ngoko. They talk about their job using Indonesian loan words, but the Indonesian loan leads to the occurrence of other Indonesian forms. (The Indonesian and its translation are underlined.)

$$
\begin{aligned}
& \text { 1. A. Dhapat apa, Fé Ka Tiga? Mitirgin? 'What do the patients in } \\
& \text { B.K. Three (the name of a ward) get? Mitirgin?' } \\
& \text { Mitirgin, sinfasinôn, sama kaliyum. Sinfosinôn lima yunit. } \\
& \text { 'Mitirgin, Sinfosinon, and Kalium. Five units of Sinfosinon.' }
\end{aligned}
$$

A. Karo sisané? Ora tô? 'How about the rest of the Sinfosinon? Do you give it, or not?'

B. Ora sidô sisané. 'The rest is not going to be given.'

In this example there is no reason for the choice of Indonesian dhapat apa 'what do they get?', tiga 'three', sama 'and', lima 'five', over their Javanese analogues, except for the influence of the Indonesian loans around them (the names of the medicines). The conversation is basically in Javanese, and sentences which do not contain Indonesian learned borrowings also contain no other Indonesian forms. Another example: a conversation where a peasant vendor describes methods of fertilization. This time a whole Indonesian phrase is borrowed into Javanese, because the concept to which it refers was learned through extension literature (which uses Indonesian).

2. Ha mbôten ngerti. Ha mergi nèq dhé ès ontog menyuborkan tanaman, sèt a ontoq membesarkan buwahnya, nggéh tô? 'Well, I don't know. Because D.S. [a kind of fertilizer] is to fertilize the plants, whereas $\overline{\text { Z.A. }}$ is to make them bear bigger fruit, you know what I mean?'

The portion in Indonesian is not necessarily strictly confined to the part of the utterance which refers to the subject matter, but of ten spills over into other parts. For example, in the following utterance the shift to Indonesian occurs two words prior to the forms that refer to economics, the subject which gave rise to Indonesian. (This utterance also shows a shift from Madyô to Krômô in the use of niki 'this' (M) and menikô 'this (K)--Sec. 4.3.1.)

3. Wah, 1ha niki kadôs terutama mengenai bidhang êkonomi menikô. 'Well, this is like, umm, especially concerning economics.'

When Indonesian takes this first form, the form of a series of loan words or loan phrases in a Javanese utterance, the basic markers of the speech levels are kept intact. If the level is Krômô, the sentence is typically Indonesian sprinkled with Javanese forms which clearly indicate $\mathrm{K}$ level: ngaten 'thus', menikô 'this, that', nggéh 'yes', sampon 'already', and so on. Thus in citation 2, above, the Indonesian phrase is set off by nggéh tô 'follow me?' which serves to clarify the speech level as Krômô. 
Another example on the $\mathrm{K}$ level occurs in a discussion of matters directly concerning school, where Indonesian loan words or even loan sentences are used. Otherwise, the utterance is in Javanese Krômô. But even the sentence which we might call an 'Indonesian loan sentence' has a $\mathrm{K}$ form menikô 'that' inserted, a device which keeps the speech level clear.

4. Lajeng kulô raq enggêh menikô kéngéng pon wastani dadôs panitiya menerima murét. Wônten maléh anu menikô, masalah laré yhang nilénya kurang begitu baéq, ato anaq yhang dhatang menikô bisa diterima. 'Further, I could also be called the admissions committee. Further, there is, umm, the problem of the child whose grades aren't good enough or whether the child that comes can be accepted.'

A further example of this type of mixture--Indonesian with just enough Javanese to keep the level clear appears in Citation 1 of Sec. 3.2, below.

This same type of Indonesian-Javanese mixture occurs in utterances on the $\mathrm{N}$ level when there is a reason to keep the level clear. For example, prostitutes are addressed in Ngoko, but there may be reasons for a switch to Indonesian. In the following example a man tries to soothe one of the girls who has been upset about an accusation made against her:

5. Kuwi, wektu kuwi néng maqaf, yhô, nèq katakataku nanti, janganjangan ngantèq menyinggong perasaanmu, maqaf yhô. 'At that time, but I'm sorry $\mathrm{f}$ I say something that might, well it might just hurt your feelings. Sorry, yeah?'

The repetition of yhô and the forms ngantèq and kuwi keep the feeling of a $\mathrm{N}$ level clear. (We will discuss later the reason for the switch to Indonesian in this particular type of context in Sec. 3.5.2.)

There is a second form which Indonesian can take in conversations which involve Javanese speakers. This occurs when Indonesian is chosen, not because of the subject matter, but rather because the relationship among the speakers is sufficiently unclear for no speech level choice to be proper. In this case, forms which clearly indicate speech level are avoided and the Indonesian analogue is chosen. The speech level, then, remains unclear. We may thus say that Indonesian is a speech level of avoidance, chosen to obviate the use of Javanese speech levels. We discuss this type of Indonesian borrowing in Sec. 3.4 .

A third type of Indonesian borrowing occurs in Peranakan speech. We discuss this usage in Chapter 5.

\subsection{Subject Matters and Settings \\ in Which Indonesian is Chosen}

Indonesian is the normal mode of communication for matters of an official or governmental nature. Conversations connected with these matters or in settings where these subjects are discussed tend to be in Indonesian. The most frequent example is school talk, not only the subject matter taught, but also the talk about things that go on in school, or even conversation conducted on school premises. There are parallels for other matters for which Indonesian is used: courts and police, politics, problems of science and engineering, family planning, etc. In Section 3.1.1 above, Citation 1 shows Indonesian in hospital talk, and Citation 2 shows Indonesian entering a discussion of fertilization (reflecting the use of Indonesian in extension 
education.) Citation 4 occurs in a discussion of school admissions reflecting the use of Indonesian in the school setting. We give here a few other examples of subject matters and settings where Indonesian is used. The first is from a discussion about a transaction with a bank that failed. (The level is Krômô.)

1. Nêng kulô sadé kintenkinten nggèh, paling banyaq yha separohnya dapatnya uwang. 'But when I sold it, I got about, umm, at the most half of my money back.'

At another point the same speaker, telling about how the bank manager went into hiding, again discusses the bank's operations in Indonesian:

2. Dadôs dengan beberapa staf itu dibawaq kesana. Dadôs kantôr péndhah nèng ndheléq. 'So, he had brought (the bank) and several staff members to that place. So, they moved the office to a hiding place.

The following is an example of Indonesian being used for technical subjects (here recharging batteries):

3. A. Enggéh. Nikô soqalé platé akèh. Platnya lebéh banyaq, setromnya lebéh tahan lama. 'Yes, the thing about that is that it has more plates. The more plates the longer the charge lasts.'

B. Ngôten. Néng regané pirô? 'Oh yes. But how much does it cost?'

The use of Indonesian in government offices is reflected in the following two citations where the speaker quotes pieces of conversations held in the office. A teacher recounts how he had a problem getting excused for his absence because he did not see the doctor. His commentary stays in Javanese.

4. Nyatané "saya sakét tapi tidhaq ke dhôkter." Koq njaloq surat dhôkter. "Ha dari mana?" aku ngono. 'So what happened was, "ffell, I was sick, but I did not see a doctor." Why should they ask for a doctor's certification anyway? "So where am I supposed to get one from?" I said.'

In the following example a servant, whose master is about to get him a government job, fails to perform satisfactorily. The master's brother takes him aside and tells him that he will intervene to withdraw the application unless he reforms. What he is going to say to the personnel director is put in Indonesian. Also actions connected with the office are expressed with Indonesian loans:

5. Dadi kulô iséq isô mempengaruhi ajengô sampan mpon dugi tahap semônten nikô. "Saya bilang Dhếq Ratnô nyemlangi. Diputoskan saja." Kulô saget. 'So I could still influence the decision even though you have gotten this far already. "Let me tell you, Ratnô is unreliable. I think you'd better reject him." I could just do that.'

The legal language is Indonesian, and discussions involving court cases, licensing, and the like show loan phrases or sentences in Indonesian. The following is an example about licensing a motorcycle (in Krômô):

6. A. Lha éngkang setunggal dèrèng baléq nama. 'One of them has not been registered in the new owner's name. ' 
B. Kalo baru itu ada sumbangan apa begitu? Wônten tambahan? 'How about new ones? Do you have to make some sort of contribution or something? Do you pay extra?'

A. Kalo yhang baru itu peraturan énggal menikô. 'For the new ones, there are new regulations about them.'

Normally Indonesian is used for giving definitions (a practice which reflects the use of Indonesian in schools):

7. Teros wôngé rôdô fanatik barang, ngandel aku. Fanatik, bukan fanatik dalam arti agama, tapi fanatik dalam arti dhiri. 'Anyway, the buy is a fanatic, if you ask me. A fanatic, but not in the sense of religion, but in the sense of the kind of person he is.'

Formal meetings among people who know each other from work or school are commonly carried out with Indonesian. For example, a group of students are planning a picnic. They speak Indonesian and Ngoko. (Their code for normal social intercourse is Ngoko.) Utterances directed to someone are in Ngoko, whereas those of an official nature, directed to the group on the subject, are in Indonesian.

8. A. Njoq kuwi biyayane pirô? 'And what is the cost?'

B. Telong atos sèket, bermalam dibuatkan kémah. 'Three hundred fifty, for the camping fees overnight.'

A. Nèq utang olèh, ora? 'Can we pay later?'

B. Makan duwa kali. 'There are two meals.'

C. Ngandel ora? 'You believe that?'

D. Kowé dikôngkôn meneng whaé. '(to C) Hey, it's not your turn to talk.'

The choice of Indonesian does not necessarily imply that the conversation is serious. In the following conversation a young man jestingly upbraids his cousin, a doctor, for not giving a clear explanation of some medical problem. The doctor was intentionally obscure, and the cousin, by choosing Indonesian, creates the scene of a courtroom:

9. Lha ini terdhaqwa anu, memberikan keterangan yhang menyulétkan. 'This man is charged with giving explanations which lead to even more confusion.'

\subsection{Indonesian as a Method of Giving Importance to the Utterance}

The choice of Indonesian as a code for certain official sorts of subject matter lends an official character (or mock dignity) to the utterance. For example, two friends, who speak to each other on the $\mathrm{N}$ level, discuss borrowing a book. The one who wants to borrow it has been constantly put off, and he chooses Indonesian to attract the listener's attention and underline that he had already been promised the book:

1. A. Sésoq whaé pô bukuné, kowé. Nèq arep nyilêh. . 'How about if you get the book tomorrow. If you want to borrow it...'

B. Pasti sudah janji. 'But you already promised it.' 
A. Ora, saqiki ra ônô. Lha piyé tô? 'But I haven't got it now. What am I supposed to do?'

B. Ha kôq digôwô ngiwô nengen. 'We11, why did you let it out of your hands?'

The dignity may be in complete jest. For example, in a conversation involving students (carried out in Ngoko), a girl explains to the boys the proper way of dealing with girls. She uses Indonesian loan phrases and sentences as if she were taking the role of a teacher. The boy answers with Indonesian loan forms as if he were the student:

2. A. Lho nèq kuwi ki lagi tahap permulaqan. 'We1l, when you get to that you are only at the beginning stage.'

B. Tahap pertama. 'The first stage.'

A. Prolok jé. 'The prologue, don't you know?' B. Lha yhô. Di situlah letaq. . 'Of course. That's the point

In the following exchange two nurses discuss moving a baby and oxygen from one room to another. A 's choice of Indonesian is from the need to be business-like. The subject and setting demands Indonesian. B's answer is a joke. She chooses Indonesian to give a mock business-like tone, but purposely uses a colloquial Indonesian form, dimatiqin 'kill it' as a joke:

3. A. Nanti bersamasama membawa 0 duwa. Kamu mendorong 0 duwa. Saya membawa anaqnya. 'We' 11 move the $\mathrm{O}_{2}$ together. You push the $\mathrm{O}_{2}$ and I'11 carry the baby.

B. Dimatiqin dulu sebentar. 'Let the baby die for a moment [since

Indonesian is often used as device for lending importance to what is being said. A speaker thus can make his position more convincing, or make himself important in the eyes of his interlocutors. This use of Indonesian is reflected in Javanese novels where switches into Indonesian are employed as a device for character portrayal. An example is the following citation from the speech of a defeated aspirant for the post of village headman. He is described as speaking too loudly with waving arms and badly formed sentences, enough to condemn him as a person not in control of himself. ' But switches to Indonesian even more clearly communicate the man's character. When he wishes to accuse the incumbent headman of incompetence in a meeting, he intermixes Indonesian with his Javanese, and this the reader takes as a sign that he is trying to show off, or give additional weight to his opinions, opinions which by themselves would not stand up. The speaker also uses an Indonesianized Javanese form, atawa 'or', a kind of form characteristic of the speech of ill-educated Javanese. The utterance is on the $\mathrm{K}$ level.

1. This selection is taken from a novel Kembang Kanthil by Senggono (Jakarta: Balai Pustaka, 1965), p. 11. The character description of the speaker reads as follows:

Anggoné celathu nggenthalang (ngumandhang), tangané karo srawêan, nangéng ukarané akèh kang nyimpang sôkô jejer. 'He spoke with a booming (resounding) voice. His hands waved wildly, and his sentences were often il1 formed.' 
4. Kôlô lurah éngkang rumiyén, nalikô dhuson menikô dados laladan patrôli Welandi. Tekôq dhuson aman lan tentrem, tidhaq adha thèthèq bengèq, tidhaq adha maléng atawa pembakaran tetapi. . . è nangéng saqmenikô saben jam wôlu sônten utawi jam sôngô, jethông diponiringi penjeritipon tiyang alộ "maléng" utawi "kôbôngan". Menikô ateges Naq Darmén tidhaq cakap dhan tidhaq bijaqsana. 'The last headman was when the village was under Dutch control. How come the village was quiet and peaceful? We didn't have any of those things we don't need--no thieves or fires but. . . umm, but now, every evening at eight o'clock or nine o'clock you hear the alarm and people shouting"thief!" or "fire!" That is a sign that Darmin is incapable and unintelligent. '

This excerpt exemplifies the use of Indonesian as a self-defense mechanism, which we have also found frequently in our materials. In the following citation a worker reports to an outsider about a coworkers of whom he is jealous: ${ }^{2}$

5. Méng kulô menikô kuwatôs kulô meniô, ông larélaré mriki mahaséswa mriki niô.. . és yhéh anu, sami pinterpinter nai mrayu. Nanti kaloq orang . . kelihatan orang aséng ros dhidhekati. Lajeng, yhô, nanti teros mudhah dhianggap sebagé . . . dhijadhikan asistènnya. 'But I am concerned, I am, because these young people, those students here.. - umm, you know they're good at flattery. And so if someone - . if they see a foreigner, they just go right up to him. So, umm, then the foreigner probably thinks that they are umm . . so he hires them as assistants.

Another example: the speaker discusses why he suspects one of the employees of the project for this study of having stolen a tape recorder. Again the Indonesian is to impress the interlocutors that the speaker has thought things through carefully. (The Indonesian forms are also bookish.) The speech level is Krômô.

6. Ha menikô kulô meniô, beberapa onsor niô kulô pelajari, apakah ini karena pimpinan yhang satu akan segera pulang ke luwar negri? Ini setelah pulang, dhiya . . umpama tidhaq dipaka1 sudhah membawa itu, engko njot ngakuné ro kluwargô ro kôncô "hadhiyah sekô lé dadi asistèn," saget. 'Well, so in this case, I, umm, studied some of the basic facts. Could this be because one of the project heads is going back home to his own country? After he has gone he (his assistant) . . . if they don't use it . . - why not take it. Then he will say to his family and friends, "I got this as a present because I was an assistant." That is a possibility.'

We have numerous examples of speakers who trot out their Indonesian to show that they are not complete bumpkins. For example, a local village official meets a former fellow-townsman who left Central Java many years ago and is How back on a visit. He sprinkles Indonesian in his conversation as a sign that he has kept up with the times, even if he has never left home. In this case he repeats in Indonesian what he said in Javanese. The level shifts between Krômô and Madyô:

2. This citation is also a good example of code shift from lack of control (Sec. 4.4.3). The forms underlined twice are Ngoko, and are out of place. The sentences are ill-formed. The speaker is upset. 
7. Menikô putrané mbah kulô sekéng selér séng ketelu. Selér yhang ketiga. 'That is the son of my grandfather by wife number three. Wife number three.'

In some cases the speaker is not on the defensive, but merely wishes to assert that he knows better. In the following discussion about a car that has mechanical problems, two acquaintances talk (in the M level) about testing it out. One says he would race it at top speed to see what happens, whereas the other says that it is already certain that at forty the car begins to rattle:

8. A. A empon, mbôten sah. 'Oh no. It's not necessary.'

B. Néng pôkôqé swidaq niku. 'But anyway run it at sixty.'

A. Asal enampuloh itu kirakira maséh stabil ngôten men. 'Well it's pretty much stabilized at sixty. ${ }^{3}$ Just do it like that.'

\subsection{Indonesian as a Neutral Speech Level}

Indonesian is frequently used as a device for obviating references to status or intimacy which are clear in Javanese. Situations which lead to the choice of Indonesian neutral speech level are: (1) where the relationships between the participants in the conversation are such that they call for two different code choices which conflict with one another--i.e., where two pragmatic factors which lead to a certain code choice are in conflict; (2) where there has been a change over time in the relative status or relationship between the participants or where modern life conflicts with older usage; (3) where the Javanese calls for a choice between using or not using an honorific, but where the status of the person spoken or referred to is too high for the absence of an honorific but too low for its employment.

It is important to note that this device is not readily available at all times because Indonesian is not always an appropriate code. The choice of Indonesian in many cases creates tension, distance, a feeling of pretentiousness, or the like, and is thus an inappropriate code. Indonesian is an appropriate code for social conversation only in the case of speakers who know each other from work or school and have frequent occasion to speak in Indonesian, and for use on the topics and in the situations discussed in Sec. 3.2, above. For speakers who do not have the Indonesian option, a sentence can contain at most only one or two Indonesian loan words before a feeling of inappropriateness arises. But even among speakers who have the Indonesian option open to them, an effort is made to have the conversation sound Javanese by mixing Indonesian and Javanese. We have practically no examples among Javanese speakers of pure Indonesian used for socializing.

\subsubsection{Indonesian as a Means for Resolving Conflicts in Code Choice}

A typical example of the choice of Indonesian as a device for obviating conflicts is the situation where two persons of widely differing ages work or study together in the same institution and have exactly the same rank. People who work together are on a pseudo-intimate level, very much like coworkers who are on a first-name basis in America: they are not intimate in

3. The speaker misspoke. He meant forty. 
reality, but custom recuires them to speak as if they were. However, it creates conflicts for a person to use Ngoko to someone old enough to be his father or mother, especially if he is, in fact, not really intimate with the addressee, but is just in this pseudo-intimate relationship. In that case Indonesian with $\mathrm{N}$ or $\mathrm{K}$ admixture is the code adopted. But the forms which most clearly indicate speech level are Indonesianized. For example, Javanese demonstratives and other forms from Lists One A and One B of Sec. 2.2.1 above, which most clearly indicate speech level, are avoided and Indonesian usually substituted. The older interlocutor will usually answer with the same sort of speech. In conversations of this sort we usually find constant code shifting: Krômô to Ngoko, or Krômô with Indonesian to Ngoko, back to Krômô again, or back to Ngoko, or Ngoko with Indonesian, and so forth. (Occasionally, Madyô is one of the codes, but most such cases involve priyayi and Madyô is not available.) The speakers do not adhere to Indonesian, for this is considered inappropriate, as discussed above in Sec. 3.2. The following citation is from a conversation involving five persons, all of whom are at the same rank in an office. But three of them are twenty years older than the other two. The pseudo-intimacy of coworkers requires Ngoko, but the age difference requires Krômô. Persons of the same generation address each other with Ngoko without difficulty. In this particular conversation, people of different generations begin speaking krômô. Within five minutes, however, the older speakers begin attempts to switch to Ngoko, but they maintain them for only a couple of minutes before going to Indonesian with $\mathrm{K}$ admixture and then to Indonesian with $\mathrm{N}$ admixture, moving on to pure Ngoko. But at the end of the conversation the people give up at trying to be intimate and stick to the $\mathrm{K}$ level. The informant who made this recording stated his opinion that this type of shifting goes on in all of the conversations in the office. (Indonesian is underlined once; Krômô, twice; Ngoko is unmarked, and forms which are neither clearly any level nor clearly Indonesian are in capitals.) $A$ is 54 years old; $B, 32$; C, 52:

1. A. Sebab kalo orang itu biyasanya dhengan ANU meniô, dhôbel pilén, maén sondher dhôbel pilén mniô gelô. 'Because if a person is accustomed to UMM a double weave, if he plays with the single weave, he will not like it.'

B. Enjếh. 'Yes.'

C. Mbiyèn ki paléng hébat LAIYEN niô, njêh? . . Wônten éngkang langkong saé maléh . - . yhang BUTERPLÉ, yhang ANU yhang nômer satu. Niốnjêh saqiki regané pirô, yhô? Mbiyén ndilalaé awaqee dhéwé tuku BUTERPLE nematusan mungan. Yha Tô? . . . Sekarang tikel telu. 'Formerly, the best was the LION, wasn't it? . . There is even a better one, the BUTTERFLY is UMM number one. That's umm let's see now, how much was it? Formerly we got the Butterfly for only six hundred, didn't we? Now it is at least double.'

B. LHA ini YONÉYAMA itu séng wèqé MAS WODHO. Sana lé tuku SUGENG. Wés bédô. 'BUT now the YONEYAMA which MAS WODHO owns . . He bought a SUGENG there. It is a new model.'

C. Yhô Tô. 'Is that so?'

B. Yhô. 'Yes.' 
Conflicts of this sort often arise when people are assigned certain roles, but have not as yet had time to establish the personal relationship that would allow them to assume these roles readily. The following citation is from the conversation of staff members of our project, three of whom had worked together for several months and felt at home with one another, and one of whom had been with us for only a short time. They were all students in their twenties and thus of the age and status which calls for the mutual exchange of Ngoko, but the new member was from a different institution. He still felt himself, and his colleagues considered him, to be an outsider, although he had been thrust into the role of 'one of the group' by virtue of being on the project together with the others. The newcomer speaks Krômô and receives Madyô. But when the conversation moves to a humorous, slightly race plane, the newcomer tries to close ranks. He begins to bridge the gap by using a pretend-didactic Indonesian (underlined once) since the subject matter is one for which Indonesian is acceptable, but with $\mathrm{N}$ mixture. However, he is quickly placed firmly as an outsider by the choice of Krômô (underlined twice) on the part of one of the old-timers:

01d-timer 1: Lho keluarga berencana ki kàrèq arep rencana sithéq pô rencana banyaq? 'Family planning means to plan for a small family or for a large family.'

old-timer 2: (laughs)

Newcomer: Mémang ka bé ki mencegah keluarga besar. 'Actually family planning is to keep from having a large family.'

01d-timer 1: 0 . 'Oh.'

Newcomer: Rencana banyaqpon bisa terlaksana: 'It is applicable to planning for a large family, too.'

01d-timer 1: Banyaq bisa. 'It's applicable to planning for lots of

old-timer 3: Cèn ndandani yhô marai. 'But really its purpose is to make life better. It causes. . .'

old-timer 1: Marai ngôpô? 'What does it cause?'

(general laughter--the reference is to the notion that family planning is associated with having a free sex life)

Newcomer: Bôcôr. 'If there's a leak.' (Meant as a joke. If there is a leak in the condum it causes babies.)

01d-timer 3: Énggêh. 'Yes.'

\subsubsection{Indonesian as a Device to Correct a Wrong Code Choice}

In some cases a speaker chooses a speech level which the interlocutor feels is inappropriate. The interlocutor may then switch to Indonesian (actually Indonesian-Javanese mixture) to avoid the feeling of uneasiness which inappropriate speech level choice creates. Indonesian itself is inappropriate, but choosing it only conveys a feeling of artificiality or pretentiousness and does not create the strong tension resulting from the use of the wrong speech level. In the following example, a college student addresses a vendor older than himself with Ngoko. Use of Ngoko with an older stranger is clear evidence of a wide social gap (Sec. 2.1.2.1), and, were 
the vendor to answer in Madyô, it would be clear acknowledgement of the great inferiority of his status to that of the student. On the other hand, if he were to respond in Ngoko, he would be pretending to be in the same social class as the student (i.e., a student himself--see Sec. 2.1.2.2). He tries speaking in Ngoko but, conscious of its inappropriateness, he switches to Indonesian. The student continues to use Ngoko except for a few Indonesian loan words:

Student: Nèq kowê dhêwê soq, ôpô slama rông taon ki yhô meneng whaé? 'How about you yourself, will,. . . will you abstain for two years?'

Vendor: Hai iyô no umom pôqé dhaérah nggônaku kuwi, kecuwali adha yhang ndhaq sadhar, ya, itu. 'Yes, that's common in my area, in my place. Except there are some that are not conscious of it [family planning].

\subsubsection{Indonesian as a Device for Addressing Several Interlocutors}

A speaker must often address several interlocutors with whom he has different relationships. If he uses Ngoko, he is clearly excluding the interlocutors who should be addressed with Madyô or Krômô, while by using Madyô or Krômô he excludes the people with whom he is on $\mathrm{N}$ terms. The device most frequently employed to handle this situation is non-directed speech (discussed below, Sec. 4.2.3), but its use is not always possible or may carry connotations which the speaker wishes to avoid. In such situations, Indonesian is used, if it is appropriate, such as for people who know each other from settings where it is employed. Indonesian then becomes a device by which a speaker may keep contact with interlocutors to whom the level of speech he is using is not appropriate. For example, in the following citation, the speaker starts using the $N$ level, but he is not on $N$ terms with all of his audience. Thus for the audience with whom he is on $M$ terms and to whom he cannot use Ngoko, he intersperses Indonesian, as the only device available for including them. He cannot switch to Madyô, as this would clearly exclude those in the audience with whom he is on $\mathrm{N}$ terms. The feelings of the audience are very much analogous to those of an American audience in a conversation when the speaker keeps shifting his gaze from one part of the group to another.

1. Sôquôq yhô padhané tanganan. Lha, anaq saya tu yha, yhang gedhégedhé itu . . . Wés saiki nèq bocah ki golèq séng cedhaq. 'It is often a question of how good the doctor is. My older children... Anyway, now I just take my children to the one [doctor] that is close by.'

In the following citation the speaker starts out on the $\mathrm{K}$ level, but he expands his audience to include some with whom he is on $\mathrm{N}$ or $\mathrm{M}$ terms. For the audience for whom Krômô is inappropriate he chooses Indonesian (not Ngoko, for this would very clearly exclude his $\mathrm{K}$ audience). (In this situation nondirected speech is also difficult to use, for it also tends to give a feeling of intimacy [lowers the level]. The speaker is not on that kind of terms with much of his audience.)

2. Wònten téori ngaten. Néng nggêh empirés mniô, kalo éstri itu konsentrasinya itu padha swami lebéh kuwat. 'I have a theory, 
empirically founded, that the wife concentrates her attention much more on her husband [than he does to her].'

In citation 4 of Sec. 4.2.4, the speaker combines non-directed speech and Indonesian for addressing a group.

\subsubsection{Indonesian as a Device for Distinguishing Asides from the Principal Narration}

Similar to this, is the use of Indonesian as a device for keeping individual parts of the same discourse separate. Conversational asides are typically made in Indonesian (or usually in Indonesian with Javanese admixture, or vice versa), and the main thread of the narration is pure Javanese--i.e., it is as though the narrator were recounting the story to one group of people and commenting on it to another. This use of Indonesian is again found only among people who have the option of speaking Indonesian (by virtue of the fact that they know each other from settings where Indonesian is norma1). In the following citation the Indonesian asides are in parentheses:

Baqdô, pesangôn sakéng ngriki, tumbasakan griyô wônten rikô. (Bambang dhitanam dhi sana.) Kanggé sedhèrèqipon satu tô! Bambang meniô. (Pôkôqnya ndhaq dhapat. Sampèq Bambang yang dhisanapon, yha, ndhaq krasan, kembali lagi, yha.) Saqmangké nggéh kempal kan Paq Jôkô. 'Afterwards, to repay him for dispossessing him, they bought him a house there. (They had Bambang stay there.) That was for the one brother, Bambang. (In any case it didn't work out. When Bambang got there, he did not like it and went home.) Now he lives with Mr. Joko.'

\subsubsection{Choice of Indonesian in Order to Adjust to a Change of Status or to Speech Level Usage Which Has Changed in Recent Times}

Most commonly two speakers who have known each other well continue to employ the same code throughout life, regardless of changes in their relative status and despite the tensions that this may cause. (See the citation 3 from the speech of a monk who became a bus conductor, Sec. 4.3.4, below.) In cases where a resort to Indonesian is possible, however, this option is frequently taken. For example, a village school teacher meets an old student who, meanwhile, has gone on to get a Ph.D. The former relation between them is one of Ngoko on the part of the teacher and Krômô (or Madyô) on the part of the student. When they meet again, the student continues to speak Krômô, but the teacher now speaks the sort of Indonesian-Javanese mixture that obscures the speech leve1 (Secs. 3.1.1 and 3.4). (Unfortunately we failed to record this conversation.) The use of Indonesian was possible here because the speakers knew each other from school.

Changes of accepted usage in speech levels have led to a recourse to Indonesian. In the traditional governmental structure of Central Java, superiors spoke to inferiors in Ngoko, and inferiors addressed their superiors with Krômô (except in the case of the very top echelons, where the courtiers had, and still maintain, a special court speech). Nowadays, a person of white collar status cannot be addressed with Ngoko by a superior whom he must address in Krômô. Receiving Ngoko and giving Krômô implies that the lower-ranking person is a child or that he is a servant of the higher-ranking person, and not a white collar employee (Sec. 2.1.2.1). In 
this case we find that the lower-ranking employees still speak Krômô to their superiors, but the superiors resort to an Indonesian mixture. The employee does not have the status entitling him to be addressed in Krômô by highranking officials, and yet Ngoko is out of the question. (Madyô is also our of the question, because people in traditional court circles regard Madyô as wrong Krômô and avoid it.)

\subsubsection{Shift to Indonesian to Avoid Honorifics or High Speech}

Indonesian is chosen where the Javanese form has too high or formal a connotation. For example, in the following citation about a party for a junior high graduation, the Indonesian form dirayakan 'be celebrated' is chosen rather than the Javanese dipahargyô, which refers to a much more formal affair. There are other purely Javanese ways to express the notion of getting together informally, but they do not quite fit the idea of a graduation party, and in any case they do not come to mine.

1. Ha, nganti dirayakan. Paq Jôkôné diundang. 'They went so far as to hold a party for it. Mr. Jôkô was invited.'

A similar phenomenon is the use of Indonesian maqaf 'I'm sorry' for Javanese pangapurô (or $\mathrm{K}$ pangapunten) 'forgive me', which is a sincere and formal request for pardon. For example in citation 5 of Sec. 3.1.1, above, a thug asks a prostitute to pardon him if he said something to hurt her feelings. He says maqaf yhô 'sorry!' not pangapurô 'Please forgive me.'

We also have examples where Indonesian was chosen to avoid honorifics. In the following citation, the discussion is about where an American will live. The portion of the utterance meaning 'to live somewhere' is put into Indonesian to avoid the Javanese form which clearly ascribes status. Manggèn 'live' is not high enough for an American and lenggah 'reside' is too high for this particular American, who is just a young student.

2. Lha lajeng saqmenikô kepéngén nglajengaken bôsô Êndonésiyanipon, patang wulan maléh ngaten. Mawi tèhnik menikô, anu, hidhop jadhi satu rumah tangga. 'Anyway, now he wants to improve his Indonesian for four more months. Using that technique, umm, living in the same household (with Indonesians).'

In the following example, a man explains why he did not go to live with someone who had invited him to, saying that the man is very mean about food, although his house is nice. The speaker chooses Indonesian tempat 'place' to carry the meaning 'house', to avoid choosing between $\mathrm{K}$ griyô (which is not fitting for a well-off man's house), and KI dalem (which is appropriate to the house but incongruous in the context, as it would give honor to a person who is being criticized). In this case a neutral Javanese term nggèn is available, but the Indonesian form simply came to mind.

3. "Nèq kulô mang kurungi teng nggèn sampèyan, a nèq ngenèi segô jangan kluwéh wê kôq, karo grèh . . ." Koq mbôten. Tempaté niku mbôten. ' (So I said to him) "If you have me stay with you and then all you give me to eat is rice and breadfruit or salt fish . ." His place is not (poor. Just the food is.)' 


\subsection{Other Factors Which Lead to a Choice of Indonesian}

\subsubsection{Indonesian as a Device to Cover up Incompetence in Javanese}

Speakers who come from humble backgrounds or from areas with strong dialectical peculiarities, and whose speech might well reveal their origins, have little confidence in their way of speaking and thus have a strong tendency to resort to Indonesian. Their motivation is somewhat different from that involved when Indonesian is used as a device for showing off (as for example in citations 5-8 of Sec. 3.3, above), for here it is more a device for concealment. An example showing this kind of motivation comes from the speech of a teacher from a poor peasant family who, in speaking to his fellow teachers (and others of respectable status), switches periodically into Indonesian. He uses enough Javanese admixture to keep the feeling of speaking Javanese, but he consistently avoids forms which call for using honorifics such as say, give, obtain, and the like (since they obligate a choice of Krômô Andhap, Krômô Inggil, or the nonmarked $\mathrm{K}$ or $\mathrm{N}$ forms, and this is the sort of choice that offers the greatest difficulty). In these cases he uses the Indonesian analogue or leaves the word unspoken:

\section{Peasant teacher: Aspilèks. Dhiberi dhulu resèp Dhôqter Déwi, malah rong taq. . 'Aspilex. Dr. Dewi gave him a pre- scription, but I haven't [bought it for him].' (In this case the speaker purposely left unspoken the notion 'bought' which would require a choice between an honorific or none.) \\ Interlocutor: Pél tô? 'Pills?' \\ Peasant teacher: Itu nanti digeros hé iso. Turon panas. 'You can just pulverize it. It brings the fever down.'}

\subsubsection{Indonesian for Euphemism}

Indonesian may be used as a device for avoiding personal embarrassment on the part of the speaker. A young man tells about his sister's getting pregnant and then being forced to marry. He starts explaining the situation by quoting his thoughts in Ngoko, but switches to Indonesian to avoid having to speak plainly. (In fact, even in Indonesian he uses a circumlocution, saying merely that he hopes his worst fears do not turn out to be true.)

1. A. Kantonkanton wônten Turban sewulan criyôs kulô, "Mas, aku kôq lat!" 'Later on, when $I$ had been in Turban a month she informed me, "I'm late!"'

B. "Aku kôq anu agèq tiléq réné, agèq kirém layang réné" raq ngaten tô niku. 'By "I'm late" I suppose she meant "I'm sorry I informed you too late--came here too late or sent you a letter too late."'

A. Mbôten. "Aku kôq lat" kintonipon serat adhéq menikô. "Whé, iki . . - janganjangan dugaan saya semula itu terjadhi," kulô ngaten tô. "No. Her letter said "I'm late!" I thought, "Oh-oh, now . . . umm . . . I just hope that what I have been suspecting all along is not really the case." That's what I said to myself.' 
Sometimes Indonesian is chosen to relax a feeling of embarrassment which one has (or is supposed to have) in discussing a delicate subject. In the following citation a young boy discusses the fact that he is not officially the girl's boyfriend but that they have an understanding.

2. Belum adha sesuatu pernyatagan, belum adha proklamasi, belum adha. Aku ki rhong tau anu barang. 'There has been no announcement, no official proclamation, no .. . I have never gone and you know [told anyone I'm going steady].'

Indonesian colloquial forms are often used as a sort of joke (citation 3 of Sec. 3.3 also illustrates this). Joking with Indonesian may be used as a device for softening the hurtful effects of a harsh criticism, e.g., a mistress scolds her servant, using colloquial Indonesian gimana 'What's the matter with you':

3. Wo, Kang Man ki gimana ini tadhi, lé mu nyumeti lampu kôq tanpô nutop jendhélô ki piyê. 'Oh, Man, what's the matter with you! You lighted the lamp without closing the window.'

\subsubsection{Indonesian as a Method of Disclosing Personal Feelings}

Direct disclosure of one's personal innermost feelings is rarely done by use of Javanese. They may be disclosed indirectly (as we shall discuss later) or by using Indonesian. Informants say that they react to an Indonesian utterance not as the opening of one's heart, but rather as a dispassionate, scientific description. For example, it is unthinkable to say 'I love you' in Javanese. A sane person simply could not bring himself to express this in Javanese, although a perfectly grammatical sentence with this meaning could be constructed. However, Indonesian Aku cinta 'I love you' sounds just fine. One informant said that this Indonesian phrase sounds as though the speaker were discussing someone's feelings on a medical or psychological plane with another person who was not directly involved. We may say that Indonesian does not express the feelings of the ego but can communicate what the ego feels when there is need to do so. Thus, Indonesian has become the language of love, a usage that is reflected in love letters. For example, a young man quotes a hypothetical letter to a girl:

Pôkôqé ngôten koq, "dhengan sepucoq surat ini saya memberi kabar mbaq . . " In any case, this is the way it goes, "With this letter I notify you ..."'

\subsubsection{Indonesian Forms Which Are on Their Way to Being Adopted as Loan Words}

Sometimes an Indonesian form has no good Javanese translation, or the Javanese form is uncommon, and Indonesian is inserted into the Javanese. In such cases, we may well say that Javanese is on the way to adopting a certain Indonesian form, for the switch to Indonesian has no particular function or reason other than that its form comes to mind. ${ }^{4}$ The Indonesian forms

4. This is not to say that the occasional introduction of Indonesian loans does not elevate the style. It does. In the following citation an oft-used Indonesian phrase is inserted. It must be quoted in Indonesian because the 
which are used to avoid the high, formal connotation of Javanese, discussed in Sec. 3.4.6, above, are in this category.

However, such Indonesian forms in Javanese speech are still not assimilated loans, for they influence the words surrounding them. (The words surrounding them may be Indonesianized by attraction.) The speakers who use these forms are those who have frequent occasion to speak Indonesian. (We have no example of such forms in the speech of people who can or do speak little Indonesian.) For example, in the following utterance selama 'during' is chosen because the Javanese equivalent is not frequent. But the demonstrative which follows selama is also Indonesian. The utterance is in the midst of five minutes of $\mathrm{K} \mathrm{speech}$ with no other Indonesian forms:

1. Dadôs selama itu mbôten émot, nggéh, mbôten nôpônôpô sampon. Lajeng, anu, pejah sepalêh. 'So for that time he was unconscious, didn't know anything. He was, umm, half-way dead.'

A whole phrase may be put into Indonesian under the influence of a potential loan word of this type. In the following citation, the Javanese equivalent of harapan 'hopes' in the meaning of this context is rare. The common Javanese translation pengajengajeng does not fit.

2. A. Putranipon nômer kaléh raq ènten ngrikô. 'His second child is there, you know.'

B. Éngkang nembé kôlô mbèn mlebet? 'The one who just got a job the other day?'

A. Enggéh. Pegawé bang . . Harapan bisa membantu orang tuwa. 'Yes. In a bank. He hopes to help his parents.'

B. Enggêh. 'Yes.'

A. Séng mbarep, anu, gagal sekolah. 'The eldest, umm, failed out of school.'

It is not a requirement for a potential loanword of this sort to have no common Javanese equivalent. We have numerous cases of Indonesian forms slipping into Javanese where a perfectly common Javanese analogue exists. Such usages are frequent with speakers who have much occasion to speak Indonesian. For example, a young law student uses the Indonesian tiyap bulan where the Javanese $\mathrm{K}$ saben wulan ( $\mathrm{N}$ sasi) is common:

3. Sésoq dicedhèqi manèh, yhô, "Sampéyan mbayar tiap bulan raq kiyat?" 'Then he comes back to him the next day, you know, "You can pay every month, can't you?"'

Citation 3, of Section 3.4.6, above, also exemplifies this phenomenon. We discuss this phenomenon further in Sec. 6.2.

Javanese analogue is not used. The phrase, however, does not really say anything that had not been said heretofore, and its real purpose is to fancify the style and give the utterance (and the speaker) a measure of importance (by the process described in Sec. 3.3, above):

Nggêh mugimugi kulô dongaqaken sagetô kaleksanan padôs ragat piyambaq, dhan menghasélkan yhang sebagosbagosnya, menikô pon. 'I just pray that hopefully you can manage to make your way and do as well as you can, that's all.' 


\subsection{Codes Used with Outsiders}

Javanese are reluctant to use their own language with non-Javanese until a close, friendly relationship has been established. This stems partly from the feeling that outsiders could not possibly know Javanese. An example is the recording of a wedding ceremony in a Catholic church of a Javanese-speaking parish where the groom was an Australian. The priest uses Javanese Krômô to ask forgiveness for diverging from the normal code and to give the congregation commands. But the ceremony itself, which involves the Australian, is in Indonesian:

1. Kulô nyuwon pangapunten déné upôcôrô menikô mbôten nawi bôsô Jawi nangéng bôsô Éndhonésiya. Atas nama Bapak dhan Putra dhan Rôh Kudus. Amin . . pôrô rawoh sôhô pôrô lenggah sedôyô. 'I ask your forgiveness than this ceremony is not in Javanese but rather in Indonesian. In the name of the Father, and of the Son, and of the Holy Spirit. Amen . - all of the guests and congregation be seated."

Another impetus for speaking Indonesian to outsiders is the feeling that Bôsô is difficult and that outsiders are unlikely to be able to master it, so one runs the risk of being addressed with the wrong level. A third impetus to speaking Indonesian with non-Javanese is the element of prestige, for Indonesian is the language of learning and of interethnic communication. It is therefore the proper language to use in speaking to outsiders, and use of Javanese in such a situation is a clear sign of one's inability to speak Indonesian. People of the lowest strata--pedicab drivers, vendors, and the like--might well speak to a foreigner in Javanese, if they are addressed in that language and are people of no pretensions; but even they will sometimes insist on using Indonesian as a sign that they have some education, especial$1 y$ if the foreigner uses a low-level Javanese. ${ }^{5}$ The following citation illustrates the tendency to use Indonesian with an outsider. The speaker is a priyayi, and the situation is as follows: a stranger comes up to a lady's house and asks (in Javanese) if a certain doctor still lives there. The Javanese he uses is marked with a foreign accent and also with an inappropriate shift to Ngoko. The lady answers in Indonesian. The shift to Ngoko may also have had something to do with her electing to respond in Indonesian.

2. Lady: (to herself) Lho sôpô kaé. 'Who's that?'

Stranger: Ndarani dôkteré isêh... 'I thought the doctor still . . .'

Lady: (to herse1f) Dôkteré ora omahé kéné. 'This isn't the doctor's house here.'

Stranger: Dôkteré niku pundi? 'Where is the doctor?'

Lady: Bintaran. 'On Bintaran Street.'

5. The American co-author would usually try to speak a low Madyô to pedicab drivers. The response was sometimes in Indonesian, especially on the part of younger drivers (who usually are less willing to accept a low status than older drivers). However, if the American switched to full krômô, the pedicab driver would usually switch to Javanese (but not necessarily higher than the M leve1). 
Stranger: (in $\mathrm{N}$ but clearly directed at the lady) 0, Bintaran, yhô. Bintaran tengah, yhô? 'Oh Bintaran? Middle Bintaran Street?'

Lady: Bintaran tengah, saya koq lupa - . Saya lupa nomornya berapa. Ndaq tau, ya. 'Yes. Middle Bintaran. I forget, I forget the number. I'm sorry, I don't know.'

One problem with using Indonesian is that it gives a feeling of distance and that one is in some sort of official situation. Thus Javanese who become intimate with outsiders try to use Javanese with them. A good example of this is in a conversation among two Javanese sisters and two Batak boys. One of the Bataks $(M)$ is a close friend of the girls (in fact, he claims to have a romantic interest in the elder sister), but he knows Javanese only passively. The other Batak (W) is meeting the girls for the first time, and does not reveal whether or not he knows Javanese, although it is clear from his reactions that he understands. With $M$ both girls invariably use Javanese (except when their speech is influenced by $M$ 's Indonesian). With $W$, they invariably use Indonesian. The following citation exemplifies this usage. W tells the two girls (N and I) how he lost the key to M's bicycle in the restaurant and had to leave the bicycle there. $N$ tells how she saw someone carrying a bicycle that was locked and asks $M$ if he saw it. (Indonesian is underlined.)

3. W: Di mana? 'Where [did you see it]?'

N: Entah. Dari sana itu, ya, ditaréq-taréq ke sana. Kowé weroh, Malau? 'I don't know. He was coming from there and they were carrying it over that way. Did you see it, Malau?'

M: Gèq sepèda siapa? 'Whose bicycle?'

$\mathrm{N}$ : Mboh. Ora ngerti aku. Wông nggôwô spédha kôq digèrèt mrônô kaé. Kunciné ilang! 'I don't know. I don't know. Someone took away a bicycle dragging it in that direction. The key was missing!'

M: Ah, aku takut jugaq nanti spédhaku itu. Nanti diambil orang kuncinya dapat, kan. Trus diambil spédanya itu. 'I am afraid that they are going to do the same thing to my bike. If someone finds the key they could easily take the bike away, couldn't they?"

N: A, tapi seng nitéq sôpô kan kono ngerti. 'But you know who you left it with, don't you?' (To W:) Di warung, ya? 'At the restaurant, wasn't it?'

If the conversation is addressed to both $\mathrm{M}$ and $\mathrm{W}$, the girls use Indonesian, even when in a joking mood. For example, in teasing $M$ that another girl has a crush on him, the girls use Indonesian, as they are addressing $W$ at the same time:

4. M: Dia saja nggaq mau. 'But she doesn't want me.'

I: Mau kôg. Kamu yang nggaq mau. 'She does so. You are the one who doesn't want her.'

$\mathrm{N}$ : Sudah bilang sama saya! Dia bilang, "Eh, saya mau sama Malau," gitu. 'She told me. She said, "I like Malau," she said.' 
We have other examples of Javanese Ngoko to outsiders: Javanese wives to husbands who come from Bali, Bima, and Flores (none of whom know Javanese); an ex-landlady to the same Flores man who boarded with her for years; a Peranakan student to his close Batak friend. We have no recording of Bôsô to outsiders, but plenty of first-hand experience. 


\section{CHAPTER 4}

\section{SHIFTS IN THE SPEECH LEVEL}

\subsection{Introduction}

We have few specimens of utterances of any length that are limited strictly to one speech level. Except in formal speeches and ceremonies, there is a constant movement from one level to another. The most common reason for the shift is introduction of quotations--either from someone else's actual or potential remarks, or from one's own thoughts--since such references are usually made on the speech level (or assumed speech level) of the original quoted utterance. Quotation of one's own thoughts (thinking aloud--something like English 'God, how my head aches') we call NON-DIRECTED SPEECH. Such speech is normally on the $\mathrm{N}$ level.

Shifts of speech level also occur for numerous other reasons: lack of control, uncertainty of the relative status of the speaker and interlocutors, or conflicts in the various parameters of their relationship such that no code is quite right, change in attitude, rhetorical effect, and so on.

\subsection{Quoting Others}

Quotations are normally on the speech level of the original utterance. For example, in the following citation a man tells about a boy who borrowed a bike from him which subsequently got stolen. The man's speech is in Madyô (as this is the speech level he uses with his interlocutor). The words of the boy are also in Madyô as the boy uses Madyô to him. The words which the man uttered to the boy are in Ngoko (his normal speech to the boy). Madyô is underlined:

1. Man: Ha wingi kulô wedènwedèni. "Piyé kowé wingi, kowé isêh arep bali ngalôr ora?" Kulô ngôten. 'So yesterday I kind of scared him a bit. "What about yesterday. Had you been planning to go out again or what?" That is what I said.'

Boy: "Mbôten." "No, I didn't plan to."'

Man: "Ha nèq ora bali ngalôr, yhô, pité dibalèqké ngono!" Kulô ngôten. '"Well if you weren't planning to go out, you should have put the bike back!" That's what I said."

Boy: "Lha pon kulô wangsolké kôq̣!" "'I did put it back!"'

Man: "Kôq balèqké ngendi wông ra ônô." ""Where did you put it, since it isn't here!"'

The speech level and honorifics themselves are often clear enough devices for indicating a quotation without the need to give clues such as 'I said, he said', etc. For example, the following citation is from the con- 
versation of a husband and wife with a folk midwife. Their youngest child (aged two) is present, and the mother quotes her conversation with the child without expressly stating that she is doing so. But this meaning is clear from the speech levels and honorifics involved.

2. Midwife: (to little gir1) Pô arep ragé1 pô, woq? 'Are you going to be the youngest?'

Husband: (putting words in his daughter's mouth) Heqe, enggêh, mbah. 'Uh-huh. Yes, Grandma.'

Midwife: (to husband and wife) Enggéh? 'Really?'

Wife: "'Nèq séng disuwon ibu, nggêh, ragêl kôq mbah,' ngono." (1aughs) '(So, I said to my daughter) "You tell grandma, 'What Mother is asking for is that I stay the youngest.'"'

The choice of $N$ ngono of its $M$ analogue is sufficient to carry the meaning which we translated with a parenthetical aside (so, I said to my daughter) and 'You tell'. The form ngono in this case must be a quotation of the mother's speech to her daughter, because with almost any other speaker or interlocutor in the context the $M$ form (ngoten) would be used. We translate

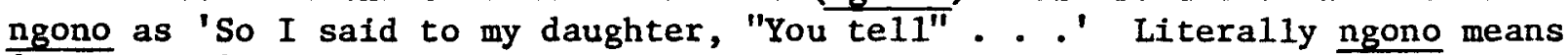
'1ike that'.

This does not mean that speakers necessarily quote speech levels accurately. In the following citation a seller of snacks quotes a customer who upbraids her for not attending to him. She quotes him as using KI diparingi 'I will give you', when in reality the person quoted would not use Krômô Inggil to refer to himself. She quotes him as using krômô Inggil instead of the ordinary $\mathrm{N}$ form which he would normally have used. This usage is no doubt under the influence of her own normal use of Krômô Inggil in direct speech to refer to him:

3. "Mbôq Dhé Sôntô!" "Dalem," aku ngono. "Arep diparingi dhuwêt ngesit whaé." "'Aunt Sôntô!" I said, "Yes, sir?" "I was going to give you money and you just rush off."'

\subsection{Non-Directed Speech}

The Javanese engage in a great deal of non-directed speech--that is, speech that is on the surface directed only to oneself, although in most cases it really is aimed at someone else. It is a commonly employed rhetorical device, and Javanese has several names for this type of speech: ngudôrôsô, 'analyze one's own feelings', ngunandikô 'soliloquize', ngudhar gagasan 'analyze one's own thoughts', and so on. Non-directed speech is often (but by no means always) marked by special lower pitches and even intonation, and, further, there is often an introductory word or phrase, e.g., tha wông 'the case is . . .', jané 'actually', néng kôq 'but then, now come . . ', pôkôqé 'we11, the fact is that...', 1ha jenè 'you ask for it...' The speaker in some cases will also mark his non-directed speech with a comment such as ngôten 'that is the way my thinking runs', enggéh tô 'don't you think so', and the like. But intonation or other overt markers do not invariably occur. In the absence of any overt markers of non-directed speech we must rely on interpretation of the situation and context to distinguish non-directed speech from speech spoken directly to an interlocutor. If speech shows a shift to Ngoko from a higher speech level, there may well be non-directed 
speech, but non-directed speech is only one of many possible reasons for the shift to Ngoko. However, even in the absence of overt markers native speakers show an ability to recognize non-directed speech as such. We tested our texts with native speakers who were not involved in the original conversation, and they were consistently able to identify non-directed speech as such, simply by listening to the recording. Evidently, the intention of non-directed speech is rarely misunderstood, even without any clues in the form of overt marking.

The basic function of non-directed speech is to quote one's feelings aloud, but at the same time to retain one's feeling of respect (pekewoh) toward one's interlocutor. Bôsô does not express one's own feelings: people typically report that they do not feel they themselves are talking if they speak Bôsô. But it is important that this kind of $\mathrm{N}$ speech is not directed at anyone, and speakers do not really look at their interlocutors as they use this device. ${ }^{1}$ We shall go further into the functions of non-directed speech shortly.

The extent to which one engages in non-directed speech is largely a matter of personality, and the degree of certainty with which one has placed oneself and one's interlocutor. People use non-directed speech when they want to obscure the mutual status; for example, if they are reluctant to grant or withhold status from their interlocutor, or feel uncertain of his proper placement. The degree of intimacy certainly affects the extent to which this device is used. The more intimate the speaker is with his interlocutor the more likely he is to employ it, for the less he is obliged to indicate status overtly. Non-directed speech, then, is an extremely widely used rhetorical device, occurring in a high percentage of conversations, with the exception of those consisting of narration (where only one person does most of the talking).

In form, non-directed speech is on the $\mathrm{N}$ level, and it is often identifiable to the analyst by the switch from a higher level. In the following citation the speaker offers her guest something to drink in Madyô and then remarks as if to herself in Ngoko that she does not have anything to offer to eat (but in fact she is apologizing). The non-directed speech (in Ngoko) is put in parentheses (a device for indicating non-directed speech which we will employ throughout this chapter):

1. Nggô, dèn, mangké unjuq̣an toyô benéng mingang [laughter] (Ha ra ônô nyamiqané kôq, yhô?) 'Here, drink your glass of water, honey. (And here I don't have a thing to offer her to go with it!) ${ }^{2}$

Sometimes there is no hesitancy in using the $\mathrm{N}$ first person pronouns in nondirected speech, such as in the following citation where a seller of tableware urges a customer to take a piece home on approval. The customer expresses what she feels to herself, using the $\mathrm{N}$ first person form aku:

2. A. Mônggô kulô aturi tindaqtindaq. Menikô kulô aturi ngastô

1. It is not considered bad form in Java to look away when talking to someone.

2. The host must apologize for whatever he serves as a means of showing humility (andhap asôr), and one way to do this is to deprecate it. Here the hostess says she is only offering water and has nothing to go with it, when in fact there were rice cakes and tea. 
setunggal. 'How about just going around [and comparing prices]? Here take one with you.'

B. Mbôten. (Aku wegah.) 'No thanks. (I don't like to do that sort of thing.)'

We also have examples where speakers flounder between directed and nondirected speech, and daily experience indicates that this is very frequent. In the following citation, the second person is given $\mathrm{KI}$ reference and the speaker refers to himself with the Bôsô kulô even though he is in fact engaging in non-directed speech. The second sentence of this quotation showed the typical pitch of non-directed speech. The underlined forms are Bôsô forms which normally do not occur in non-directed speech:

3. Kulô méng ajeng ngerti (dhôngé ki kepriyé) ngôten. (Lha nèq penjenengan rawoh, mengko raq kulô isô ngerti lôrôlarané kepriyé.) 'I only wanted to find out (exactly what is going on here) that's all. (Well, when you get here, I'll find out exactly what the problem is.) 3

\subsubsection{Functions of Non-Directed Speech as Thinking Aloud}

Non-directed speech is an utterance or part of an utterance directed not at an interlocutor but at oneself, as when talking to oneself or thinking aloud. The following citation illustrates non-directed speech, thinking aloud. In all of the examples in this section the utterances are Bôsô and the non-directed speech (put in parentheses) is in Ngoko.

1. Wônten éngkang langkong saé maléh. Niô nggêh (saqiki regané pirô, yhô?) 'There is a better kind. It costs... (let me see, how much does it cost now?)'

This usage is clearly shown on the radio. In a program of commentary, the announcer greets and takes leave of his audience in Krômô but gives his commentary in Ngoko:

2. Nuwon pôrô pamiyarsô kakong miwah putri, Paq Besot tumunten badhé ngudhar gagasan: (Tanggal selawé kepungkor iki ....) Kadôs cekap semanten rumiyén ator penungandikanipon Paq Besot . . ' 'Good evening, members of the audience, ladies and gentlemen. Here follows a commentary from your friendly announcer Pak Besot: (On the twenty-fifth of this month....) And herewith we must end our program . . .'

An example of this usage from our recordings:

3. (ôpô, yhô, ki persuné pemerintah ôpô? ôpô persuné sôpô?) kulô niku sôq malah... ' (Is it a government regulation or whose idea is it?) I often ask myself ...'

3. I do not believe English speakers use this sort of rhetorical device to nearly as great an extent as Javanese do, so that the translation sounds peculiar in English. The shifts in tense of the English reflect directed speech which reports past events and non-directed speech which reports present thoughts. Javanese does not express tense in these sentences, but the level shifts and the intonation make it clear that here we are dealing with non-directed speech. 
Or the non-directed speech may quote something a third person thought to himself :

4. Wo. Lha niku nèq lé dilorènglorèng niku, soq malah tônggô dhéwé supôyô . - (gèn ôjô ngertèni) ngôten. 'He disguised himself with stripes so that even his neighbor couldn't . . . (so they won't recognize me.) That's what he thought.'

Commonly held truths are commonly expressed by thinking aloud:

5. Bolipon malah kindhaqan kulô ngantôs... (Gèq lé medhon ki kapan?) 'The prices went up and up. I did not know what to do . . . (But when do the prices ever come down?)'

Non-directed speech is also used to relate one's own state of being, opinion, reactions, and the like. For example, in the following citation a man reports his reactions upon being told that he must pay for the upkeep of a prisoner, arrested at his complaint, until the date of the trial:

6. (Wés kemalingan, isêh kôn ngingoni uwông) nggéh? '(The man steals from me. But that's not enough. I'm still supposed to feed him.) What do you think of that?'

In the following citation some men express their opinions as to how tobacco is cured these days (as compared with previous times). The opinion is expressed as thoughts uttered aloud in non-directed speech:

7. Mbôten kôyô saqniki. Saqniki mulô naq mpon ngrasaqké, kakukaku pon. (Penggarapé kurang teliti, saraté ora dicaqké.) 'Not like nowadays. It's somewhat stiff, if you feel it. (It is all carelessly done, they don't bother to follow the proper steps.)'

Opinions which support something that someone else said are often also put in the guise of non-directed speech. For example, the interlocutors of the speaker in citation 7, above, support his opinions with their own thoughts uttered aloud:

8. B. (Cepet lé arep golèq dhét.) '(They just want to get money quickly.)'

C. (Pôkôqé bèn ndang dadi dhuwét) nggêh? ' (The main thing is that they can get money right away), isn't that so?'

The following citations exemplify the kinds of facts about one's own person which one reports with non-directed speech:

9. Nggêh saqniki anu mawôn, sêng dirembuk niki. Wah, kulô . . . (yhô rôdô jiguh nèq rembugan....) 'All right. Let's just change the subject. I . . ( I get uneasy when the subject gets to that sort of thing.)'

10. Mongkô njenengan sôq ngagem bôsô Énggerés. (Haku ki lé ngerti ora tekan.) 'You'11 start speaking English. (I can't handle English.)'

11. (Dhité rong ônô naq patang gram. Kakèhan.) '(I don't have enough money for four grams [of gold]. That's more than I can afford.)'

The fact which is related with non-directed speech may well refer to a particular incident: 
12. Nèq dhèq kulô jan pon nglisis. (Wés ora sah opernam, ora barang.) 'In my own case, it was simple. (No registering, none of that sort of bother.)'

This is the way Ngoko is generally used in narrations: oral narrations are usually in Ngoko; and written literature is also in Ngoko, except where the words of the characters themselves are being quoted. speech:

General observations about the world are often made by non-directed

13. Néng séng mbôten nduwê lemah tanah (yhô omah yhô nyéwô). 'People who don't have land (well they have to rent their homes)...'

Explanations of how things work or what generally happens are often made with this non-directed speech. For example, about a game of cards:

14. Nèq séng kowah nyôcôk niku (padhané nèq tambor, yhô, kuduné metuné tambor). Niku ntoq loro. 'Now if you get the hand called kowah nyôcôk (for instance if you have a "drum" you have to draw a second "drum"). That hand [i.e., the kowah nyôcôk] gets two points. 14

Ngoko is also used for proverbs or oft-repeated maxims (an extension of the use of non-directed speech to express commonly held truths). For example in the following citation a lady explains that she decided not to move in with her sister because brothers and sisters will invariably quarrel after any length of time, referring to the maxim: Sedinô rông dinô apéq, suwésuwé, yhô, bengkréq. 'They get along for a day or two. But after a while they must quarrel.'

15. Hanjêh. Ancasipon . . Néng kulô menikô antawés (sedulor) menikô (sedinô rông dinô) njệh (suwêsuwé, yhô, sôq bengkréq). 'Well, that was the plan . . But I always say, "Brothers and sisters get along for one or two days, but after a while they must quarre1."'

\subsubsection{Non-Directed Speech as a Device for Indirection}

Non-directed speech is also a device for indirection, a way of saying something indirectly that one has reason not to put directly. In Java indirection is highly prized as a means for preserving the smooth interpersonal relations essential to the maintenance of peace and harmony (tôtô tentrem), the ethic which underlies all conduct (Sec. 2.1, above). Indirection is a way of approaching one's interlocutor carefully, as a sign of showing respect for his status (pekéwoh), or as a way of not startling him (and thus upsetting his serenity--feeling of ayem tentrem) and, at the same time, giving him a chance to react in a way that will not disturb the harmonious relationship between the two parties. For example, a request or suggestion is put indirectly: the petitioner communicates his desire without ever asking, and he thus cannot be thought to be presuming or taking liberties (failing to feel proper pekewoh). Further, in this way the interlocutor, if he

4. In Central Java they play for eggs (each player contributing so many eggs to the pot at the start of the game), so that in this case the player with a kowah nyôcôk gets two eggs. 
wishes not to comply, can do so without creating a feeling of imbalance in himself or his interlocutor, for he has not really been asked. The petitioner, in turn, pretends to himself that he has never asked and thus can avoid any feeling of rejection or humiliation, even though he has been clearly made to understand that the request would not be granted. The petitioner also can feel ayem tentrem in the knowledge that he has saved his interlocutor from feeling awkwardness at having to give a reply that will cause unhappiness. In the following citation, a speaker tries to find out something from his interlocutor by quoting a question which he puts to himself, rather than by asking his interlocutor directly. The interlocutor thus has the option of not really answering. Also the speaker shows that he feels pekéwoh to the interlocutor by making a careful approach:

1. Néng dhèq niku thengerthenger niu, nôpô, (kaé, wông ki séng dipenggalêh ôpô kôq jaq lé kondor kor thengerthenger) nô niô? 'But yesterday you were in such a dreamy mood. (I said to myself, what is troubling that girl that she came home in such a dreamy mood?) What is that?'

In the following citation the speaker (B) refuses an invitation to Mas Padmô's house (because he has already promised to go elsewhere). Again he does not refuse Mas Padmô directly, but rather expresses it by thinking aloud. Mas Padmô was present, having come to fetch the speaker to his house, and the non-directed speech spares Mas Padmô from any feelings of rejection:

2. Mas Padmô [calling B to come] (Wés kethopraqan no jaréné. Wés "alôqalôq husé" engko.) '(It's time for the kethopraq program. It's time for the "bong-bong" of the gamelan orchestra.)'

B. Ha nggéh. (Karo Mas Padmô mono. Méng taq semayani mundor jê.) 'O.K. Coming. (I'll go to Mas Padmô's, too. But I already said I had to postpone it.)'

Non-directed speech may be used to give advice. Again the underlying philosophy is that the interlocutor has not really been told to do anything and thus may disregard the advice if he so chooses. Here a speaker advises an acquaintance to use a better light, using Ngoko as if speaking to himself (where he normally uses Madyô to this interlocutor):

3. (Lampuné, yhô, ngrusaqké mripat ki waa . . . walah wông kéné remengremeng whé.) '(That lamp is enough to ruin anybody's eyes . . Heavens, this flickering is awful.)'

Non-directed speech may also be a device for upbraiding. In the following citation taken from a radio comedy program a young man upbraids an older man for doing something wrong. He asks the older man not to do that, please, and then in Ngoko wonders aloud how a grown-up man could do such a thing:

4. Mbôq mpon ngôten, paq, nggêh tô? (Wông wês tuwô kôq pôdhô kôyô ngono.) 'I would say not to do like that, you know what I mean? (How can a full-grown man do such a thing!)'

of course, this citation is from the speech of comedians but it is typical of remarks frequently made. The following is an example from a real conversation, where the speaker jokingly chides his guests for coming rarely and 
then, some fifteen minutes later, chides them for leaving so soon. Again the speaker's normal code is Krômô, but this chiding is presented as his own opinion uttered to himself:

5. A. Sugeng tô rawohipon? (Sekô mBarèq ki adôh hé. Ngliwati cegatan wernôwernô.) Kôq mbôten wônten éngkang ndèrèq? 'Welcome. Did you have a good trip? (It's such a long way from Barek and it's such a difficult trip. ${ }^{5}$ ) How come you came alone?'

[1ater]

B. Lha niki jané nggéh méng sekedhap ôq. 'Actually, we can only stay a short time.'

A. Wa injêh, mangké kôq 1é .. . Wah (mbôq yhô sekaliseka1i. Tamutamuan ki kuduné, yhô?) 'Yes, of course. But how come you . . . (They come here so rarely. When people who are almost like members of the family come, they ought to stay at least two or three hours!)'

Sometimes the negative comment which one makes by thinking aloud concerns a third person.

6. Mbaq Siti anu di . . menôpô (digong karo Mas Nantô). 'Siti is unm, how should I put it. (She is spoiled by Mas Nantô.)'

Non-directed speech is also used for praise where direct praise might be embarrassing. ${ }^{6}$ In the following citation a lady praises another lady with whom she is on $M$ terms for doing the cooking for a certain affair by remarking on it in Ngoko:

7. (Wah, tujuné jêh ônô kôkiné.) '(Luckily there's still someone who is able to do the cooking.)'

The praise given in non-directed speech may be all in joke. In the following example a lady who is a successful merchant complains that her hand is sore. Her interlocutor answers in Madyô and switches to Ngoko to joke that her hand is sore because it is worn out from handling so much money:

8. A. Kulô sak kô pijet tangan [laughter]. Lê kemengkemeng nggéh namong kekeseleng. 'I just had my hands massaged. They are sore from over-exertion.'

B. Ha enjêh. (Kesel lé nampani dhuwêt.) 'Yes indeed. (Her hands must be tired from getting all that money.)'

In general, Ngoko is better for making jokes, and when the speaker is on Madyô terms with his interlocutor, he may use non-directed speech to express the joke. For example, in the following citation the talk is about a girl who got pregnant before her marriage. A says in Madyô that they could not keep it a secret because the children knew about it. B jokes in Ngoko that the children must have been spying when the intercourse took place:

5. This is said in good-natured sarcasm. Barek is actually very close to the place where this conversation was held, and it is easy to get there from Barek.

6. The recipient of the praise would be called on to deny it as a way of showing his humility (andhap asôr). 
9. A. Môngkô nggéh pon dhô ngerti 1ho, cah riki, mah cah ciléquciléq niku séng ngerti (laughter). 'So anyway, they all knew about it. The children here, . . . in fact, it was the little children who knew about it.'

B. (Ha cah ciléqciléq dhô nginjen ôq!) '(So, the children must have been peeping.)'

Non-directed speech is also a device for asking for something indirect1y. In the following citation the interlocutor has just taken out a cigarette and failed to offer the speaker one. The speaker asks for one in non-directed speech:

10. A. Timbang udot rôkôq ki, nèq aku, angor nglinteng. (Wông ndasare rôkôq ki ora nduwé.) 'I would much rather roll my own cigarettes than smoke ready-made ones, (since I don't have readymade ones).'

The non-directed comment may be by way of apology in cases where a directed apology would be much too formal. For example, in the reply to citation 10 above, the speaker (B) comments on the hint of his interlocutor (A in citation 10) directly in Madyô. He then wonders aloud in Ngoko that perhaps $A$ dropped hints because he $(B)$ had failed to offer him cigarettes:

11. B. Wah ngké gèq nyemôni kulô (rèhné ra nawani). 'You seem to be making some hints. (It is probably because I failed to offer any.)'

Citation 1 in Sec. 4.2, above, similarly exemplifies using non-directed speech for apologies.

Non-directed speech is also used for expressing appreciation, apologies, and the like where normal thanks or apologies are not appropriate. For example in response to citation 11 above, after $B$ has offered a cigarette to A, A shows his appreciation by expressing an opinion aloud (in Ngoko) on the subject of free cigarettes:

12. A. (Ra sah nglinténg tor ora ragat lho paléng énaq.) '(Cigarettes taste best if you don't have to bother rolling them and in addition to that they are free.)'

\subsubsection{Non-Directed Speech as a Way of Creating an Intimate Atmosphere}

The use of non-directed speech in a Bôsô utterance has the effect of obscuring the distance and status ascription which Bôsô gives. Thus, speakers who feel a need to lower the level (for whatever reason), but who are still constrained to speak on a high level, may resort to non-directed speech. Sometimes the non-directed speech is interspersed with an $M$ form such as nggéh 'follow me', kulô ngôten 'that's what I think', and the like which clarify the speech level, but of ten these forms are also omitted. A good example of this lowering is a conversation number four (quoted in the appendix), which involved a couple, their helper's mother, and (briefly) a neighbor. The helper is a twelve-year-old boy who lives in the house and works without pay; his mother is the wife of an elementary school teacher and older than the couple. As such she merits the respect which Madyô bestows, but this level is rather high for the mother of a household helper. 
Thus, there is a tendercy for the couple to create the feeling of a lower speech level by resorting to non-directed speech.

The taped conversation lasted about fifteen minutes and contains some seventy-one citations (some of which consist of a number of sentences). In the speech of the boy's mother, out of twelve citations, one is non-directed speech and the others are all High Madyô--actually an attempt at Krômô. The conversation of the neighbor is of a similar character to the speech of the boy's mother. But nearly half of the husband and wife's conversation is in non-directed speech. In the wife's speech, out of seventeen citations, nine are non-directed (only two with $M$ interspersion). In the husband's speech, out of thirty citations, twelve are non-directed (mostly with M interspersion). 7

\subsubsection{Non-Directed Speech Aimed at a Group}

Non-directed speech is frequently addressed to a group as a way of including all the persons in the group, even if one is on different speechlevel terms with them. One example of this sort of non-directed speech is in story-telling. Non-directed speech is also used for story-telling because it is often the device for recounting experiences, as exemplified by citation 12 of Section 4.2.1 above. In the following citation a kindergarten teacher tells her pupils a story in Ngoko, but whenever she addresses them directly she switches to Krômô. (Small children are commonly addressed in Krômô or Madyô as a means for teaching them these levels--Sec. 2.4.)

1. (Putri Dhéwi nèq ènèng bocah manot trus dadine piyé) nggéh? Seneng mbôten? ' (How does Putri Dewi feel when children are well behaved?) What do you think? Is she happy or not?'

In the following citation a woman recounts the story of her child's camping experiences largely in non-directed speech. When one of her audience asks a question directly, she answers in Madyô, her normal code with the interlocutor:

2. A. (Njot nggôwô wés. Wông lê menyang wé, séh jam setengah 1oro kôq...) '(So, they brought their food with them. When they left it was only one-thirty.)'

B. Jam pinten. 'At what time?'

A. Setengah kaléh. [Further exchanges in Madyô] Ha, pripon tô? (Ha és, piréng.) 'One-thirty. [Further exchanges in Madyô] And then what do you think happened? (Well, now when I remember the dishes...)'

Use of non-directed speech in addressing a group of people with whom one is on different speech-level terms occurs in the following citations. In the first, a young man announces to his friends (with whom he is on $\mathrm{N}$ terms) and to the vendor (with whom he is on $M$ terms) that he wants two portions (by talking to himself aloud).

3. (Aku loro) '(I think I'11 take two.)'

7. Informants judge the wife's speech as lowering the level more strongly than the husband's. Perhaps the fact that the wife's speech had few $M$ interspersions leads to this interpretation. 
In the following citation the speaker uses a combination of non-directed speech and Indonesian (underlined) (Sec. 3.4.3) to address a group of individuals with whom he is on different terms. The first sentence is addressed to a specific interlocutor (in Madyô), and then the whole group is brought in:

4. Wah asrep, ugeré jam pitu wolu mpon wiwét. (Nèq numpaq kendharaqan ki wés--kecepatan dhi atas tigapuluh--és wah anyes.) 'It is cold if you start out by seven or eight o'clock. (If you drive your motorcycle above thirty, Jesus, it's cold.)'

4.3 Switches in Level Occasioned by Tone, Subject Matter, or Changed Perception of the Interlocutor

\subsubsection{Drops in Level Occasioned by the Subject Matter or Tone}

Speakers on $\mathrm{M}$ or $\mathrm{K}$ terms with their interlocutors may switch to Ngoko to refer to something humorous or something which they wish to belittle. This usage may be looked upon as an extension of the use of Ngoko or nondirected speech of Sec. 4.2, above, but it is clearly directed at the interlocutor (and $\mathrm{N}$ first and second person pronouns are avoided). In the following citation a young man tells (in Krômô) about a widow, a white-collar employee, to whom an old man of low status took a liking. The references to the old man are in Ngoko:

1. Mniô wônten rôndhô, néng pedhamel menikô. Pedhamel dhéskôp menôpô pundi. Lajeng (disenengi karo Hartô Gembôq.) 'There is a story about the widow, but she was a white-collar employee, in the cooperative administration or wherever it was. Anyway, (the locksmith, old Hartô, took a liking to her).

This use of Ngoko often comes out in bargaining. The choice of Ngoko belittles one party and raises the status of the other (who then should be shown deference, and his opinions about the value of the item involved not questioned). In the following citation, a prospective buyer protests that cucumbers in season should not cost twenty rupiah. They should only cost five:

2. Nggéh mbôten tô. Môsôq. (Limang rupiah wẻ.) Mbôten seménéméné. (Yhô seméné wé, séng ciliqciliq.) 'Oh that can't be. That's impossible. (They should only be five rupiah.) of course, not the ones as big as these. (Ones that are as small as this one, though.)'

Rapid commands in bargaining often come out partially in Ngoko. In the following citation a buyer of used goods is trying to close a deal on articles she is getting from some students, but she uses Krômô Inggil (underlined) to refer to the students.

3. Pon. (Gèq karo) sekrépsekrép nôpô, (séq ra kagem). 'All right. (Also) any old papers you have (which you don't need).'

Jokes occasion a switch to Ngoko in directed speech. In the following citation a vendor of snacks suggests that a customer buy some for her son. The customer says (in non-directed speech) that the son had already had a treat the day before. The vendor answers in Madyô and then adds jokingly in Ngoko that he didn't pay yesterday: 
4. Customer: (Wo, wés jajan tô dhèq wingi.) '(It seems to me he already had a treat yesterday.)'

Vendor: Pon. (Néng méng jaloqké yô, Mas?) 'Yes he did. (But you know, he asked for it--he didn't pay.)'

Another example: a daughter uses Ngoko to refer jokingly to the fact she had at one time behaved contrary to her parents' wishes. (The daughter normally uses Madyô to her mother.)

5. Mother: Mumpong anaqanaqué kôyô ngono, mulô nèq wés dadi tuwô anaqee wani karo mbôqné bapaqné. 'You'd better do something now while they're small. Once they get big they will dare to go against their own parents.'

Daughter: 0o, raq ngentès tô. 'Ouch. You're hitting where it hurts [because that is true of me].'

Games may occasion a switch to Ngoko. In the following conversation the speakers begin with Madyô as they get ready to play, but once the game has commenced they all use Ngoko:

6. S: Saqniki anu, sampéyan séng ngasot niku. Niki dikasot niki.

W: Nggéh. 'All right.'

P: Pôtelôt? 'How about a pencil?'

S: Nggêh. Gôlèq teng njero séq. 'Yes. Go inside and look for one.'

(Later, as the game is in progress, Ngoko is used)

S: Saqiki salah siji ditudhéng. 'Now point to one of them.'

P: Salah siji. 'One of them.'

W: Iki. Ditudhéng iki. 'This one. Point to this one.'

S: Ditudhéng salah siji. Séng ndi? 'Point to one of them. Which one?'

\subsubsection{Raising of Speech Level for Rhetorical Effect}

The speech level may be raised for comical effect. For example, in the following citation about a neighbor who failed to invite anyone to a wedding (in Ngoko), the speaker uses the $\mathrm{K}$ form nrimah nyelili 'accept the shame people will put her to' to picture her neighbor in a humble position just answering the people's $\mathrm{N}$ taunts with Krômô:

1. Wông atasé wông éwoh mbôq yô nyeloq wông siji pô wông loro, njot akônakôn kuwiq. Kôq méng nrimah nyelili? 'Even though she was having a ceremony at her house! She could have called over a couple of people to come help and then summon the neighbors for the ceremony. How can she just sit back and submit to the shame which people will hold her in?'

A switch to a higher speech level is employed to emphasize or lend weight to a statement (much as Indonesian does--Sec. 3.3). In bargaining the level is often raised as an indication of serious intent or to flatter the other party. A prospective buyer, who had been using Madyô and Ngoko 
(with the same functions as exemplified by citation 2 of Sec. 4.3.1, above), threatens or perhaps flatters the other party, shifting to a high Madyô (where ngaten and èstu are indications of high Madyô--2.2.1).

2. Pon. Nèq ngaten, mbôten èstu mawôn nggéh? 'All right. If that is the case, let's just call it off, OK?'

In another example, where a vendor of used items invites her interlocutor to go to her native village and gives directions as to how to get there, the level rises from low Madyô to high Madyô, an indication that she was very interested in having him actually come. In an interview with a peasant about folk beliefs our researcher receives the closest to Krômô the peasant can manage, when the peasant is in the role of teacher. But when the conversation is simply to pass the time, the peasant's speech level drops.

Sometimes this rise in level combines sarcasm and emphasis. For example, a mother helping her daughter with her reading uses Ngoko, but switches to Krômô to emphasize her point:

3. Daughter: "Mreneng" heqe tô? 'It says "mreneng" doesn't it?'

Mother: Raq. 'No.'

Daughter: Heqe. 'Yes it does.'

Mother: Raq. 'No.'

Daughter: Heqe whaé kôq. 'It does so.'

Mother: Dibalèni, ora isô nèq "gemreneng". 'Look at it again. It can't be "gemreneng".'

Daughter: Heh? 'Huh?' Mother: $\frac{\text { Salah. Lepat menikô. 'That's wrong. You are in error, }}{\text { my dear.' }}$

\subsubsection{Switch in Speech Level Reflecting a Change in the Interlocutor's Perception of the Speaker}

Speech level switches also reflect temporary status ascription or some other change in the way the interlocutor is regarded. An important use of a switch to Krômô or high Madyô is as a device to ascribe priyayi status temporarily to a non-priyayi as a means of eliciting a desired reaction. Citation 2 of Section 4.3.2 above is an example of raising low Madyô to high Madyô in a bargaining situation. In the following citation (from Conversation four) the speaker moves from Madyô to Krômô when he is stating something which is going to upset the interlocutor. The interlocutor will not be able to react adversely to a reference to a painful matter either because she is flattered at having her status raised, or, having been given the status of a priyayi, it is incumbent that she not react. The discussion is between a mother and her boy's master, who wishes the boy to return home to his mother. When the events surrounding the boy's dismissal are referred to, the master moves to Krômô (underlined):

1. Ha njor Prôbô niku sampon diponweléng kaliyang Mas Patmô. 'So anyway, Prôbô has already been given a warning by Mrs. Padmô.'

On the same subject later: 
2. Mesthinipon raq Prôbô raq mator dumugi nggriyô "Aku, anu, anu ..." 'Prôbô should have reported, shouldn't he have, as soon as he came home that, "I did so-and-so . . ."'

A speaker may also choose to view the interlocutor as of lower status, and thus lower the speech level. This lowering is reflected in the use of Ngoko in bargaining, illustrated with citations 2 and 3 of Sec. 4.3 .1 above. We find such usages also in giving advice, when the speaker may temporarily ascribe the status of son to his interlocutor. In the following citation an older woman advises a young man, distantly related by marriage but to whom she has been speaking Krômô, to invest his money (not save it in a bank). For her advice she uses Ngoko. Krômô is underlined:

3. Tigang atos langkong pôkôqipon. Lho titépnô budhé. ôjô kuwatér. Tenan kôq naq. Lho iki jenengé pengalaman budhé ki wisan. Wés dawek. 'At any rate, it is a little more than three hundred. [Moving to the subject of putting money in the bank or investing it] Entrust it to your old aunt. Don't worry. Really, son. I am what you might call experienced, an expert in that sort of thing.'

A similar example is the following citation from the speech of a lady who wishes to buy tableware from an old acquaintance. Her speech is basically Madyô or Krômô, but she keeps slipping into Ngoko as a way for pretending that the seller is a close relative, creating a feeling of intimacy so that the seller might let her have the goods at cost. Bôsô is underlined once and Ngoko twice. Forms which occur in both Bôsô and Ngoko are not marked:

4. Seller: Menikô kalêh seket, mbôten. Sawek pas. Kaléh seket men mboten ndhèrèq . . 'You can't get them at two for fifty. It's a fixed price. Even if you were to offer two for fifty, you could not get them.'

Buyer: Yhô wés tô, bu .. . Yhô wés. Kalêh seket. Wah budhé ki. Th, come on, Mother. Come on. Two for fifty. Oh, Auntie!'

A lowering of speech levels often occurs in conversations between strangers who begin with Krômô but, as the status of the interlocutor becomes clearer, one or both of the speakers switch to Madyô. In a conversation between one of our researchers and a seatmate on the bus (Conversation One), the conversation begins in Krômô, but when the seatmate reveals her non-priyayi status (partly by her speech), the interviewer's speech level drops. The value of humble behavior (andhap asôr) makes it imperative that one adopt a humble attitude, and this must be reflected in speech by employing a level which is either correct or a bit too high. But if the speaker uses a level which is too high, the interlocutor is not placed properly, making him feel uneasy from the knowledge that he is failing to behave properly (not sreg). The speaker must, therefore, move his speech level downward. The following citation shows this process of starting high and moving down to the level which is really sreg. A city man goes to the home of a peasant whom he knows only slightly. He begins in Krômô, but soon switches to Madyô. The peasant continues in Krômô (at least as close to Krômô as he can manage). M forms are underlined:

2. City man: Mônggô, Paq sesipon, Paq . . Sabénipon sisêh pundi, Paq? 'Would you like a smoke? .. . Where are your ricefields?' 
Peasant: Sabén mboten gadhah. 'I don't have any ricefields.'

City man: 0 , ha niô sekéng tegal, 'Oh, so you live off your dry lands?'

Peasant: Enggêh . . Naminipon Pôgong Bakalan menikô. 'Yes, this place is called Pôgong Bakalan.'

City man: Niko sêh klebet Pôgong tô, Paq, mriki? 'That is still part of Pôgong, isn't it?'

(later)

Mônggô, Paq, sesé, Paq. Niki Paq. 'Have a smoke. Help yourself.'

\subsubsection{Shift in Speech Leve1 Because of Uncertainty in Relative Status}

We find some examples of shifts in speech level occasioned by doubts as to the proper level to use. For example, a woman addresses a niece (actually the daughter of a first cousin) in Ngoko, since the niece grew up in her neighborhood and was close to her. The niece has long since moved away and married a school teacher, whom the aunt is now meeting for the first time. Thus the aunt speaks Ngoko to the wife, but Krômô to the husband. But to use Krômô to the husband of a person one once regarded almost as a daughter is incongruous (not sreg), and we find the aunt soon speaking Ngoko. Some of this is non-directed speech and some directed at the niece (whom she normally addresses in Ngoko), but there are no interruptions like kulô ngaten 'that's what I think' or the like, and some of the Ngoko is clearly directed at the husband. Ngoko is underlined:

1. Aunt: [about money in the bank] Hanéng mbôten angsal, dipendhet. Yèn dèrèng setaon dereng angsal. 'But when you want to take it out you can't. It has to be in a year before you can withdraw it.'

Husband of niece: Soalipon menawi wônten ndalem nikô kirang aman. 'The problem is that if he keeps it at home it is unsafe.'

Aunt: Ha néng raq yhô sebagian ôpô separo ôpô pirô. 'We11, but you just take a part of it, a half or whatever amount.'

After twenty-five minutes the Aunt speaks mostly Ngoko, but goes back to Krômô every so of ten.

A change in status over time also leads to uncertainty of codes. For example, a woman, who was formerly a helper in a family living in a small town, left the family's service and is now on about the same social level as the family she served. She is intimate with the women of the house and about the same age, and thus should use Ngoko. But as a maid she was obliged to use Madyô. Thus, her former status and her present status conflict, and we find a constant shifting from Madyô to Ngoko and back again. In the following citation they are talking about someone who is getting married. Bôsô forms are underlined once, and forms which are confined to Ngoko, underlined twice. (Forms which occur both in Bôsô and Ngoko are not underlined.)

2. Tilasané nikô. Nikô jaréné pegatan. Njot arep éntoq kuwi, éntoq Hartô Indon kuwi . . Lha nggêh sugêh Hartô Indon ngono. 'She is 
his ex-wife. They say they are divorced. Anyway, she will get that man, Hartô Indon. Anyway, Hartô Indon is better off, you know.'

Another example is the case of a student who is an ex-seminarian. He meets a former brother, who has left the order and now works as a taxi starter. The ex-brother is older than the ex-seminarian. When he was a seminarian the student used Krômô to the brother, and the brother used Ngoko to the student (as would have been normal). This speech level arrangement is continued in this conversation, although it is incongruous: a taxi starter should use Krômô or Madyô to a student, and the student normally would use nothing higher than low Madyô. The student still gives the ex-brother the respect he was formerly accorded, and the ex-brother tries to continue with Ngoko to the student, but frequently raises his level to Krômô (underlined once). Forms confined to Ngoko are underlined twice, and forms which can be either Krômô or Ngoko are not underlined.

3. Student: Rômô Tantô saqmenikô wônten Nédherlan. 'Father Tantô is in the Netherlands now.'

Ex-Brother: Sinten? 'Who?'

Student: Nédherlan. Belajar. Saqumenikô réktôripon Rômô Surô. 'In the Netherlands. He is studying. Now Father Surô is the rector.'

Ex-Brother: Dhiség aku nô Girisôntô bareng Rômô Tantô kuwi . . . Dhèwèqé arep filsafat, aku mlebu nèng yunior. Néng arep filsafat ki ndadaq édan dhèwèqé. 'I used to be at Girisonto together with Father Tanto. He was going to take Philosophy, and I was in the Juniorate. But when he was going to take philosophy, he became crazy.'

Student: Édan, nggêh édan .. sampon naté... 'Oh yes, he did once become crazy.'

The situations described in Sec. 3.4 above also are often marked by shifts from Ngoko to Krômô or Madyô.

Priyayi children (children of priyayi parents) are supposed to receive Bôsô from people of lower status. But Bôsô is rarely consistently addressed to children. Whenever the adult must emphasize his position as adult vis-àvis the child, he switches to Ngoko. For example, in the following citation a vendor is addressing the five-year-old son of a family of superior status. She starts in Madyô (underlined) but switches to Ngoko as she is scolding the child. (She gives the child a deferential term of address, however: mas 'elder brother'.)

4. Kế séq, yô, mas. 'Just a minute, please.'

\subsection{Shifts in Level from Lack of Control}

\subsubsection{Drop in Level from Lack of Control over the Speech Levels}

A fairly large proportion of the population has poor control over the $\mathrm{K}$ level. Nearly all of these (aside from Peranakans--Chapter 5) are people who originate in the peasant or landless laboring classes. Such speakers sometimes find themselves in a situation where they must use the $\mathrm{K}$ code, in 
which case we find a constant dropping and propping up followed by an involuntary drop. The following citation (from Conversation four) from the speech of a middle-aged elementary school teacher's wife, who herself is from a humble family and illiterate, exemplifies this type of speech. In the Javanese in citation 1 below, the purely $\mathrm{K}$ forms are underlined once. Forms admissible in Krômô and Madyô are not given any marking. Forms inadmissible on the $\mathrm{K}$ level and found only on the $M$ or $\mathrm{N}$ levels are underlined twice, and forms which are Ngoko or Low Madyo are in capitals. The utterances of this speaker tend to drop in level the longer she speaks:

1. Hanggêh. Ha wông adatê menikô wiwêt rumiyén nikô ugerê kerengan paben kaléh Naq Wit nikô, raq nggêh ngantôs nyôq tangistangisan ngôten, néng mangké ugeré sampon saé maléh, nggéh pon mbôq nôpônôpô niku, nggêh? CAH LORO nikô, wông wiwét rumiyén ngôten niku. 'Yes. Because it has usually been the case, ever since before--whenever he fights with Wit, it often gets to the point that they start crying, but then when they are friends again, it is as though nothing happened, you know what I mean? Like two kids will do. It has always been like that since before.'

Other speakers are able to make individual short utterances consistent Krômô but are unable to sustain Krômô for long. This sort of drop is illustrated in the following citation from an elderly peasant who is being interviewed about folk beliefs. After about two or three minutes of conversation which he carries out in nearly faultless Krômô about his family and place of origin, the peasant tries to maintain Krômô when discussing the more difficult topic of folk beliefs. But we note here a drop, and then a rise again to full Krômô after there is an interruption (in Krômô). Where the level drops, the sentences are also not well formed. The forms with double underlining show the drops, and the forms with single underlining are confined to Krômô. Forms with no underlining are used in Madyô and Krômô.

2. Ngriki menikô, éngkang cikal bakal menikô namong asmanipon Mbah Gundhol. Kapitadôsanipon tiyang mriki niki nggéh teng niku . . . Enggêh kang asmô cikal bakal. Menikô papanipon wônten nggèné mbaqyuné Cariqé Pardô ngriki. Riku ônten wité bentaro [interruption in Krômô by the interlocutor] Néng sajaq saqpejahipon, nggéh sampon pindhah sangkéng mriku, dukô pindhahipon menôpô, dhateng pundi. 'Here the only cikal baka1 ${ }^{8}$ we have is one called Grandfather Bald. People here believe that this is at that . . umm, what is called cikal bakal. It's located in the house of the elder sister of the clerk of this village, Pardo. There is a bentaro tree there . . . But anyway, after he died, he moved away, I don't know what, where he moved to.'

In some cases, speakers who are unaccustomed to using Bôsô for certain subjects or in certain settings find it difficult to maintain a Bôsô level when in that context, although they may otherwise control Bôsô adequately. For example, a certain mechanic, who usually deals with people with whom he is on $\mathrm{N}$ terms, runs into difficulty when discussing repairs with someone with whom he is on Bôsô terms. When talking about repairs he finds Bôsô

8. The speaker is confused here. He is thinking of the guardian spirit, called mbau reksô. The cikal bakal is the person who is said to be the first to have settled a certain area and is in no way anything that haunts a place. 
difficult and switches to Ngoko (underlined). The drop in level here is not because the utterance is non-directed speech, for the particle raq 'don't you know' clearly indicates directed speech:

3. Ha niki nggo kerja raq suwésuwé kéné ki kélông. 'Well now, if this moves, after a while this part here is going to wear down.'

\subsubsection{Shift in Speech Level under the Influence of Immediately Preceding Forms}

The context may influence the speaker to shift speech level involuntarily. For example, a quotation in Ngoko inserted in a citation which is on the $M$ or $K$ level will occasionally cause a drop in the forms which come inmediately after it. In the following citation the speaker uses Krômô, but drops to Ngoko after the first quotation which is in Low Madyô and then again after the second quotation which is in Ngoko. The involuntary shifts are underlined:

1. Enjêh, wau nggêh pinanggêh menikô . . nganu, "Dhéq Wit, teng nggèn kulô. Dhéq Wit," nganu "kulô nèi jambu. Jambuné okèh," ngono. "Yhô mengko," aku ngono. Mangké dalu mnô ... 'Yes, anyway he met me, umm, "Wit, come over to my place. I'11 give you some jambu fruits. I have lots of jambus," says he. "OK, later," says I. That night. . .'

In some cases a speaker may simply forget to use Bôsô if he is carrying on a conversation in Ngoko and is interrupted for a moment to say something to a person whom he usually addresses in Madyô. The following citation is from the speech of a village woman, who is interrupted in the midst of recounting a story (in Ngoko) by a question concerning something else entirely from a person whom she usually addresses with Madyô. Her answer is in Ngoko (underlined), as her mind is on the story, but should have been in Madyô.

2. Ora ngerti, Purbô. Endi mau? Lho raq apéq tô? 'I don't know, Purbô. Where was I now? Isn't that funny, thought?'

The context may cause the level to be raised as well as lowered. In the following citation an old woman switches to Madyô (underlined) under the influence of the Madyô of her interlocutor, whom she otherwise addresses in Ngoko:

3. Boy: Séng nigan ènten mbôten? 'Do any of them lay eggs?'

old woman: Séng nigan sitôq, gèq lekas. 'Only one lays it just started.'

In non-directed speech or quotations, a rise in level may occur under the influence of the speech level employed in direct speech. For example in the following citation the speaker uses $M$ mawôn 'just' in quoting himself (in place of whaé) under the influence of the $M$ kulo niki 'this is what I thought':

4. (Nèq ônô kancané ngono, aku gelamgelem mawôn) kulô niki. '(If I have someone to go with me, I surely would want to go) I thought to myse1f.' 


\subsubsection{Shift in Speech Levels Caused by \\ a Temporary Loss of Self-Control}

People who have lost control of themselves can usually not manage Bôsô. On stage drunken people are presented as speaking Ngoko, even people who should be on $\mathrm{K}$ terms with one another. For example, two ministers from different kingdoms sit down and drink together. They begin speaking Krômô, but as they get drunk, out comes Ngoko (as well as secrets of their rival machinations which lead to a war). We have no recordings of real life drunkenness, but we have examples of anger. In the following citation a woman tells about her lazy son. Because of her anger, she keeps slipping from Madyô into Ngoko. The slippage is underlined:

1. Mulêh sekô ngriki, sarapan teros bali, teros mapan turu. Môngkô wau men taq kôngkôn angèlé ra jamaq. Méng tuku gandom whé begitabegitu kô maléng kuyuan. 'He goes home from here, eats breakfast, and then comes back and lies right down to sleep. Why just a while ago I tried to send him on an errand. What a job! All I wanted him to do was go buy some flour and he made a face like a thief someone emptied a chamber pot on.'

In the following citation a man tells how a doctor refused to see his child because he wife was lacking a small part of the fee. She had been allowed to sign up and wait, and then sent home:

2. Soalé niku wés didhaftarké niku. Karo séng jôgô ki. "Nggêh dipadôsi riyén mawôn artané," ngôten. "The troub $\overline{l e}$ was she had already signed up and then the guard told her, "Just go and get the money first (before you can see the doctor)."'

Citation number 5 from Sec. 3.3 above also exemplifies a shift to Ngoko in $\mathrm{K}$ speech out of anger.

In some cases, a speaker may simply forget which code he normally uses for his interlocutor. For example, a certain woman usually speaks Ngoko to a younger woman who is from the same town, but whom she meets rarely. She addresses the younger woman in Ngoko, but in the middle of the conversation asks about her grandfather in Madyô and then goes back to Ngoko. There is no explanation except that she forgot for a moment that she was on $N$ terms with her interlocutor:

\section{Simbah pundi? 'Where is your grandfather?'}

Temporary lack of control can also give rise to a wrong use of honorifics. For example, in the following citation on the $M$ level a woman tells about her mentally defective son, a subject which causes her to feel flustered and fumble for words. She substitutes a $\mathrm{KI}$ form, ngendikané, for the M form, ômôngé 'his speech' (which would have been the proper form to use in referring to her son):

4. Gadhah anu, penyakét, kôyô rôdô anu nikô lho--rôdô anu, rôdô setengah, ngendikané mbôten patèq genep. Nyambot gawé nggéh biyasa. 'He has a, umm, sickness, like, umm, he is rather, umm, a little, umm, half, . . . he doesn't speak very well. He can do ordinary work, though.' 


\subsection{Formal Speech}

In addition to speech levels and Indonesian codes, Javanese speakers also have available formal and informal stylistic variants which are largely independent of speech levels. There is a formal and informal range of Ngoko and a formal and informal range of Krômô. The choice among variants which are more or less formal is governed by similar factors to those governing formal versus informal variants in English. Written speech is at the formal end of the continum (in Java invariably so, as there is no tradition of putting informal speech in writing); speeches are forma1; songs and poems are formal; a great portion of the speech of theatrical presentations is formal. (But this depends on the genre: some productions are extemporaneous and traditionally have colloquial portions of the dialogue, or have some of their characters speak in colloquial styles.) Most important of all, ceremonies employ formal speech. From the use of the formal code in ceremonies stems its use in all speech in a serious (or mock-serious) key. For exam-

ple, formal advice to a young person, speeches of greeting to a visitor, and the comments made by the visitor to the host upon first entering, tend to be in formal speech. We often find a switch toward formal speech by a speaker who wishes to impress the interlocutor with the importance of something. (Cf. citation 1 below.)

The term "formal speech" itself embraces several codes. In addition to normal formal speech, there are archaicizing literary codes which make greater or lesser use of forms now obsolete in normal styles but which appeared in Javanese literature of centuries gone by.

But lest the reader be misled by similarities to English, we must here emphasize the great differences between the functions of the formal or literary codes in Javanese and in English. For example to fulfill the functions of the formal-informal continuum in English as spoken by middle-class Americans, the Pribumi Javanese have at their disposal not only the code of the formalinformal continuum, but also the speech levels, and, as we saw in Chapter 3, Indonesian as well. Thus, many of the functions which, in English, we associate with formal speech are occupied by Bôsô or by Indonesian in the Javanese community. The three groups of codes act on separate planes. With regard to the speech levels, for example, speech in Krômô or in Ngoko can be anywhere on the colloquial-formal continuum, but we have no examples of formal Madyô, other than the speech of persons who cannot control Krômô. (In that case, we see attempts at Krômô which fail to work out--Sec. 4.4.1.) The reason for this is that Madyô originates as colloquial Krômô. However, nowadays there are colloquial styles of Krômô quite apart from Madyô, and most of our citations of $\mathrm{K}$ speech in this paper are, in fact, in a colloquial style. Citation 2, below, exemplifies the use of Krômô in speech in a formal key. With regard to Indonesian, speech can be formal or informal: Indonesian admixture or no Indonesian admixture occurs anywhere on the continuum between formal and informal speech. Similarly, Indonesian itself can be found in formal and in informal stylistic variants. Most examples in Chapter 3 of switches to Indonesian use Indonesian which is well towards the formal end of the continuum (as attested by the occurrence of forms like setelah, apakah, verbs prefixed with ber-, and other constructions associated with written, school-book Indonesian). This is because the Indonesian occurs mainly in utterances in a serious key. But there are times when colloquial Indonesian is the proper variant, and we have examples of attempts at colloquial Indonesian, e.g., dimatiqin in citation 3, Sec. 3.3, where 
Indonesian is used in a mock-serious vein or the form gimana in citation 3 of Sec. 3.5.2, where the Indonesian is used as a euphemism or for a kind of humorous effect.

To examplify formal speech with various codes we give the following citation from the speech of a barber to a student interlocutor. The level is basically Krômô, but we see switches to Indonesian (in order to lend weight to the matter discussed--Sec. 3.3), and switches to Ngoko in nondirected speech to give the speaker the role of a father and adviser. However, the key is always one of seriousness throughout the citation and the style is formal: forms like sagetô, kelaksanan, sebap, ateges, ugô are all formal variants. The Indonesian is also formal. Indonesian is underlined once and Ngoko is put in parentheses. (Krômô is not given any marking.) At the very end the speaker inserts a small informal utterance (in Krômô) meaning 'don't you agree?' in order to change the tone from one of sermonizing to plain talking.

1. Nggêh. Mugimugi kulô dongaqaken sagetô kelaksanan padôs ragat piyambaq dan menghasilkan yang sebagusbagusnya. Menikô pon. Sebab menawi saqmenikô kulô sôq tumot prêhatôs. Étangipon (séng gelem golèq béaya dhêwê) menikô ateges (bocah séng maju néng ugô anu, nyawang wông tuwô); lho laq énjêh tô? 'Yes. I pray that you be successful in supporting yourself and that your endeavors bear the best possible fruits. That is it. I, too, have gone through much in this world and have come to understand that (for a young person to wish to be independent of his parents) can only mean (that he is a progressive son and considerate of his parents). Wouldn't you say so?'

Other examples of formal speech come from exchanges at a halalbihalal gathering, a ceremonious get-together during Idul Fitri (the season after the fasting month of Ramadan) for the purpose of asking mutual pardon. The following citation is formal not only in that the speech has been carefully composed, but also words are chosen which occur only as formal stylistic variants, e.g., sôhô 'and'. Also this citation shows a rise in speech level caused by the formality of the key (Sec. 4.3.1). The speaker usually gives the addressee (her father) Madyô but here it is clearly Krômô:

2. Njêh pareng mator bapaq, sowan kulô ngatoraken bekti kulô sôhô ngatoraken sedôyô kalepatan kulô lan saqwayahipon sedôyô mugimugi bapaq maringi pengapunten dhateng kulô. 'May I, too, be permitted to tell you, Father, that I have come here to pay my respects and the same time to ask you to grant me forgiveness for all the faults and sins which I have committed.'

An example of the same sort of speech in Ngoko (on the part of the father of the speaker of citation 2, above):

3. Clathu lan mlakuku séng oraô kedugô ditômpô menyang anaq, yhô, dingapurô karo sêng kuwôsô. 'And may the Almighty also forgive all unacceptable words and deeds on my part toward my children.'

\subsection{The Pragmatics of Stylistic Variation}

There are three types of stylistic variation available to Javanese speakers: choice of Indonesian or Javanese, speech level, or informal versus 
formal speech. Each of these types has its own function. To understand how they compare with one another we may take as our example the use of a code shift to express seriousness of intent or to lend weight to what one is saying.

For these purposes Javanese speakers have recourse to three different sorts of code shift: (1) shift to a formal style; (2) shift to a higher level (as discussed in Sec. 4.3.2); or (3) shift to Indonesian, as discussed in Sec. 3.3. This does not mean that these three types of codes are in competition, or that the speaker may choose whichever one he wishes; for the pragmatic meanings of these types of codes are quite different, as is the impetus for choosing one or the other from among them. As shown in Chapter 3, a shift to Indonesian emphasizes the status of the speaker as a person of education, whose words should be given weight by virtue of the prestige that he has as a person who speaks the school language. However, if the speaker, while wishing to speak in a serious key, does not pretend or lay claim to any superior knowledge, the switch to Indonesian is not appropriate. In that case another way must be used to express seriousness. One possibility is a shift to Krômô, which would stress that the speaker is in full control of proper behavior and that the addressee is a person of standing and importance (a priyayi). The words themselves receive weight by virtue of the fact that they are carefully chosen and addressed to a person of high status. However, in many cases Krômô is not appropriate. For example, if the addressee is regarded as one to whom fatherly advice is given, Krômô is impossible, for fathers do not address their children in Krômô. In such cases weight is lent to the utterance by use of the formal speech variation. An example of this sort of speech is citation 3 of Sec. 4.5, above, where a father formally asks pardon from his children in formal Ngoko. 
CHAPTER 5

PERANAKAN SPEECH

\subsection{Introduction}

Central Java has a large population of Chinese descent, divided, on the basis of language and culture, into two groups, the Peranakan and the Totok. The Peranakan are the people of Chinese descent who have abandoned the Chinese language. Generally they are descendents of families who have been settled in Southeast Asia for a hundred years or more. They have little interest in Chinese education or in acquiring the Chinese National Language, but are strongly oriented to the Westernized type of education of fered by Indonesia's non-Muslim institutions and often aim for a professional life outside of business. The older generation of Peranakan had a strong orientation to a Dutch education and Dutch language training, and those who had access to Dutch, continue to use it a great deal and have a certain pride in their knowledge of it. The Totok are usually descendents of more recent immigrants. Often they maintain a Chinese dialect in the home, have an interest in traditional Chinese education, or at least in learning the Chinese National Language, and no strong motivation to acquire a Westernized type of higher education or to enter the professions. Although the Totok in Central Java for the most part now also speak Indonesian and Javanese, much like the Peranakan, it is the speech of the Peranakan which is dealt with in this study. There are considerable differences in culture and attitudes between the two groups, so that what we say here about the speech of Chinese in Central Java should be taken to apply solely to the Peranakan. Totok speech in Indonesia is as yet unresearched.

The Peranakan Chinese of Central Java are Javanese in language, but their speech differs from that of native Javanese, the Pribumi, in many ways which are interesting and significant for our understanding of the processes of linguistic contact and for how cultural processes are reflected in language. The most important of these differing features is the existence of large numbers of Indonesian loanwords. These loan forms are so numerous that in some cases a legitimate question may arise as to whether the text is Javanese or Indonesian. This problem will be discussed in Sec. 5.7. We refer to Indonesian forms from the outset, but we have to postpone to Secs. 5.2f. and 5.3f. a discussion of the function of Indonesian in Peranakan speech.

In other Javanese speech areas the Peranakan Chinese speak in much the same way as those in Central Java, and what we say here about the Peranakan of Central Java is to a large extent also true of these other Peranakan; however, the basis of our study is in texts collected in Central Java.

The history of the Chinese settlement in Central Java cannot be dealt with here. It is, however, worth noting that many of the features of the 
Peranakan speech of Certral Java are unknown in the Pribumi speech of the area. It may well turn out that linguistic evidence will provide additional information on the Chinese settlement of Central Java. For example, Peranakan speech shows some forms which are found only in the Malay speech of Sumatra and Malaya (see Sec. 5.1.4.2), and others which are current in Jakarta speech, but until recently were unknown in Central Java (and still are confined to the younger generation of university students there). We are ignorant of the sources of some of the other deviations from the type of Indonesian and Javanese spoken by Pribumi in Java, but we are confident of being able to trace these when we get more information on Malay dialects, on the linguistic structures of other languages in Sumatra and Java, or on Javanese dialects. Some of these features may be ultimately traceable to the Chinese dialects.

How long this speech has been in existence, we do not know. There are members of the Peranakan speech community eighty and ninety years old, whose speech does not differ in any significant way from that of the younger generation; and many older members of the speech community remember that their own grandparents spoke the same way and did not speak Chinese.

\subsubsection{Levels and Indonesian in Peranakan Speech}

Peranakan speech consists of Javanese (of the $N$ speech leve1), Indonesian loan words, and a number of forms of Chinese or Dutch origin. The Javanese Ngoko and the Indonesian forms function in a way roughly analogous to the Javanese speech levels of the Pribumi: in Peranakan speech the Javanese forms function like Ngoko, and the Indonesian forms like Bôsô in Pribumi speech. (Peranakan speech levels will be described in Secs. 5.2 and 5.3.) Further, standard Indonesian, the type of speech which is taught in schools and which forms the basis of the written language, functions as a high code in Peranakan speech in much the same way as in Pribumi speech. However, the qualification must be added that much of the population has had little schooling in Indonesian, especially the generations born before World War II, and these people have little active control of standard Indonesian.

\subsection{Formal Features of Peranakan Speech}

\section{1 .1 Phonology}

Peranakan speech follows the phonology of the Pribumi Javanese speech community in most respects (Sec. 1.5), but in particulars there are great enough differences for Peranakan pronunciation to be instantly recognizable. It is worth noting that the lenis (pharyngealized) series $/ \mathrm{b} /, / \mathrm{d} /, / \mathrm{g} /$ and the sounds $/ 1 \mathrm{~h} /, \mathrm{wh} /$ and $/ \mathrm{yh} /$ are pronounced exactly as in native Javanese. Many Peranakan speakers lack the distinction between the two positions of the apical stops; that is, they do not make the distinction between /d/ and and $/ \mathrm{dh} /$ and $/ \mathrm{t} /$ and $/ \mathrm{th} /$. Forms with $/ \mathrm{d} /$ are pronounced $/ \mathrm{dh} /$ and forms with / $/$ are pronounced / th/ by these speakers. We have made only limited surveys, but what we have found so far is that Peranakan informants from Central Java lack these distinctions, whereas informants from East Java maintain them. It is interesting to note that the distribution of /d/ and /dh/ in the Peranakan speech of East Java does not follow that of Pribumi speech. Often Peranakan speakers in East Java have /dh/ in forms 
which have /d/ in Pribumi speech and which historically should have /d/, and also have /d/ in forms which historically should have /dh/. An example is Peranakan ngedhang 'steam rice' Pribumi (and historically) ngedang.

Since our informants do not distinguish $/ \mathrm{d} /$ and $/ \mathrm{dh} /$ and $/ \mathrm{t} /$ and $/ \mathrm{th} /$, and do not hear the distinction, we transcribe all the apical stops as d and t.

The Peranakan phonology also employs some phonemes or sequences not found in Pribumi speech, although many Peranakan do not use them. These phonemes are mostly in forms of Chinese origin. There is an aspirated voiceless series $/ \mathrm{p}^{\mathrm{c}} /, \mathrm{t}^{\mathrm{c}} /$ and $/ \mathrm{k}^{\mathrm{c}} /$ which does not occur in Pribumi speech: e.g., $\mathrm{k}^{\mathrm{c} a}$ 'foot' as in cyaq $\mathrm{k}^{\mathrm{c}_{\mathrm{a}}}$ 'go barefoot', $\mathrm{t}_{\mathrm{c}}$ ' 'pear'. Further, initial clusters with $\mathrm{Cy}$ and $\mathrm{CW}_{\mathrm{w}}$ occur in many Peranakan forms borrowed from Chinese. If these clusters occur at all in Pribumi speech, they are in forms borrowed from Peranakan speech: mbo 1wi 'no money', cyaq 'eat', etc. Also many Peranakan who have contact with Dutch use Dutch loan words with Dutch phonemes not found in Javanese.

\section{$5.1 .1 .1 / \mathrm{g} /$ and $/ \mathrm{h} /$}

On a subphonemic level, the /q/ and /h/ get a stronger and clearer pronunciation than is normal in Pribumi speech of Central Java. In the morphophonemics of /q/ there is a tendency in Pribumi Javanese speech for / $/$ / in syllable final position to be lost before anything but pause. E.g., nèq 'if' + isô 'can' tends to be pronounced /nè isô/ by the Pribumi community, whereas in Peranakan speech there is no tendency to drop /q/, and this sequence comes out invariably as /nèq isô/ in our Peranakan texts. (However, forms do exist in Pribumi speech where the final -q is never dropped.) Retention of $-q$ is peculiar to Peranakan speech in Central Java, but in East Java is found in both Peranakan and Pribumi speech. A related phenomenon of Peranakan speech is a tendency to add / $/$ to forms which end in a vowel in Pribumi speech. The best example of this are the forms oraq 'no' and its shortening raq 'no' which consistently occur with $-\mathrm{q}$ in Peranakan speech but rarely so in our recordings of Pribumi speech. This tendency to accrete final $-q$ is an areal feature occurring in the entire western half of Java, irrespective of local language--Javanese, Sundanese, or Malay (Indonesian)-but not reaching as far east as Central Java in the Pribumi speech. It is also found east of Central Java in Pribumi and Peranakan speech. Thus although the accretion of $-\mathrm{q}$ is not a peculiarly Peranakan pronunciation, its occurrence illustrates that Peranakan in Central Java do employ dialectical variants which are not employed by Pribumi from the same region. Finally, the forms maséh and miséh 'still' of Indonesian origin are given the pronunciation /maséq/ and /miséq/ respectively. The Javanese equivalents iséh and $\underline{i j e ̂ h}$ are also alternatively pronounced $\underline{i s e ́ q ~ a n d ~} \underline{i j e ́ q ~ i n ~ b o t h ~ P r i b u m i ~ a n d ~ i n ~}$ Peranakan speech.

\subsubsection{Other Phonological Characteristics}

In the pronunciation of individual forms there are often noticeable differences. Aside from the accretion of final $-q$, described above, we also find some lowering of $/ o /$ and $/ e ́ /$ in closed syllables--i.e., forms with oC and éc of Pribumi speech are sometimes pronounced /ôC/ and /èc/ in Peranakan speech. Again, these lowerings occur in the speech of Pribumi Javanese in 
East Java. This process of lowering vowels is not peculiar to Peranakan speech, but it is not found in Pribumi speech in Central Java. In short, the Peranakan dialect differs from the local Pribumi dialect in that it contains features which are characteristic of other Javanese speech areas. Further, Peranakan speakers employ some pronunciations which to our knowledge are unknown in Pribumi Javanese speech. In our texts the following have occurred: mônô, mono, and méné for native mrônô, mrono, and mréné 'go there (far)', 'go there (close)', and 'come here', respectively. There are probably others.

\subsubsection{Morphophonemics}

Peranakan speakers adhere to the rules of phonemic distribution which characterize Pribumi speech, and the Indonesian forms which occur in Peranakan speech follow the Javanese rules of phonemic distribution as we11. Further, Peranakan speech follows other Javanese morphophonemic processes. There are six morphophonemic processes, basic to Javanese morphophonemics and affecting a huge number of forms, which we find in Peranakan speech as well as in Pribumi speech and which affect forms of Indonesian provenience as well as Javanese forms.

(1) In roots /è/ does not occur as the vowel of a first open syllable when the vowel of the second syllable is /a/ or /ô/. Forms of Indonesian provenience which in Indonesian have /è/ in open syllables before /a/ are pronounced with $/ \bar{e} /$, as in the pronunciation of Indonesian by Pribumi Javanese. E.g., Indonesian mèmang 'really' is pronounced /mémang/.

(2) /éc/ and /oc/ in root final syllable are raised to /ic/ and / uc/ respectively before the addition of a suffix: pakéq 'use' but taq pakiqé 'I think I'll use it'; kirém 'send' but kiriman 'something sent' (where the Indonesian forms kirim and kiriman both have the same vowel in the final syllable of the root).

(3) $/ i /$ and $/ u /$ in the final syllable of a root are lowered to /è/ and /o/ respectively before the addition of suffixes beginning with $/ \mathrm{q} /$ and $/ \mathrm{n} /$ : bli 'buy it', blèqké 'buy for'; sapu 'sweep', sapôni 'sweep it'.

(4) Sequences of vowels are contracted by the rules of vowel contraction which operate for Javanese: kilo 'kilogram' plus -an gives kilôn 'by the kilogram' (as opposed to Indonesian kiloan); kati 'caty' plus -an gives katèn 'by the caty'.

(5) Rules of vowel harmony which characterize some of the Javanese dialects also seem to operate in the speech of Peranakan informants on our tapes. We have no detailed information on these rules of vowel harmony. One example occurs in the Purworejo dialect in which there is a tendency (or perhaps a rule that invariably operates) that, when a root has a mid vowel in the final syllable, the vowel of the preceding syllable must also be mid. E.g., tulis 'write' is pronounced tolés in this dialect. (The $i$ of the final syllable has been lowered to é by a rule that Javanese $/ i \bar{T}$ and $/ u /$ do not occur in closed syllables of a root.)

(6) In Peranakan speech, as in Pribumi speech, there is a tendency to make forms of high frequency monosyllabic, by dropping the first syllable, or, in some cases, dropping the first vowel and the consonant which follows it. The peculiarity of Peranakan speech is that this tendency also affects 
forms of Indonesian origin, which is not the case for Pribumi speech: apa 'question particle' is shortened to pa; saya ' $I^{\prime},{ }^{1}$ to ya or sa; saja 'just' to ja; ada 'at' to da; and so on. These shortenings are optional.

(7) Forms which in other languages begin with $/ \mathrm{b} / \mathrm{d} / \mathrm{j} /$ and $/ \mathrm{g} /$ are always borrowed with prenasalization in Peranakan speech: e.g., saya ndéngerké 'I heard' (Indonesian saya dengarkan). Forms of Chinese origin which begin with b, d, g are pronounced with / $\mathrm{mb} / \mathrm{nd} /$ and /ngg/ respectively.

\section{1 .2 Morphology}

The rules of Javanese morphology are faithfully followed in Peranakan speech with one important exception: the active-forming prefix $\mathrm{N}-$ is sometimes dropped in Peranakan speech. (In Pribumi speech $\mathrm{N}$ - is never dropped when its use is required.) The symbol $\mathrm{N}$ - represents prenasalization of the lenix series /b/ /d/ /g/; the substitution of a homorganic nasal for the fortis series /p/ / t / / c/ / $/$ and /q/; the substitution of /ny/ for /s/ (and on rare occasions of $/ \mathrm{n} /$ ); and represents a prefix $\mathrm{ng}$ - otherwise. The Peranakan passive forms follow the Pribumi Javanese conjugation. Peranakan speech follows the Javanese native speech option of dropping the third person passive prefix di- under certain conditions. This is a feature of Javanese grammar that we have not seen mentioned elsewhere, as it occurs only in spoken language. Dropping of di-, however, is not a mark of informal style, and in environments where it is allowed, the form without di- is the most common one. ${ }^{2}$ In the following example, the grammar rules specify diserahke 'be sent' (standard Indonesian diserahkan or Pribumi Javanese dipasrahké) instead of the form serahke without di-, which is the one used:

"Lho tapi kembangé malemé sudah diserahké" -- "0, sudah serahké tô?"

" "But the flowers the evening before were sent from here." -- "Oh, they have been sent from here, have they?"'

Some verbs have a conjugation different from Indonesian or from Javanese of the Pribumi community, e.g., sangkaqi (Indonesian sangka) 'thought'. Usua1$1 \mathrm{y}$, however, the verb is conjugated as in Pribumi Javanese, even in cases of Indonesian loan words, which the Indonesian and Javanese do not conjugate in an analogous manner. For example, ditinggal 'be left' (Indonesian ditinggalkan); diliyaqi 'be looked at' (Indonesian dilihat with no suffix-i); diikuti 'be followed', and so on.

\section{1 .3 Syntax}

The syntax of Peranakan speech differs in a few particulars from that of the Pribumi Javanese speech community, although most of its differences

1. In Peranakan speech saya is feminine; owé (wé) is the masculine counterpart. However, since saya is the general non-familiar term for ' $I$ ' in Indonesian as used throughout Java and of very high frequency, the use of saya by men is spreading, especially in the speech of men who have occasion to speak standard Indonesian. Saya and owé also mean 'yes (deferentia1)'.

2. My specimens of colloquial Malay from Kuala Lumpur show very analogous dropping of di-. We cannot specify the conditions for either Javanese or 
from written or correct Javanese turn out also to be features of colloquial Pribumi style. The syntactical forms discussed below are ones which our Pribumi Javanese informants reject, and which we ourselves have not found in Pribumi texts after having examined quite a large range of colloquial texts. Further research may well disclose that some of these forms are indeed also normal for the speech of the Pribumi community, at least in some dialects. (East Javanese informants do not regard some of them as ungrammatical.) Peranakan speech, of course, differs from standard Indonesian in all the ways which Javanese differs from Indonesian, for Peranakan is a kind of Javanese (as we shall discuss in Sec: 5.7 ).

\subsubsection{Dropping of Prepositions and Functors ${ }^{3}$}

The Indonesian preposition di occurs rarely in our texts, although we have many contexts in High level Peranakan speech (consisting largely of Indonesian provenience--Sec. 5.2.1) in which the preposition di would be required in Indonesian. The form $\mathrm{ke}$ ' to' is even more rare--it occurs in less than 2 percent of the contexts in which standard Indonesian would require ke. The reason for this divergence lies in the difference between Indonesian and Javanese grammatical structure, with Peranakan speech basically following Javanese rules. Peranakan speech has several substitutes for di and ke which are, in effect, loan translations of Javanese forms, the most common being that proper names of places and other common forms are used as locatives alone. Other common forms which occur as locatives alone are: sini, situ, and sana 'here, there, and there (distant)', mana 'where', mukaqe 'across', tempaté 'at the place of', and some other common forms. Other words are preceded in $\mathrm{H}$ level speech (consisting for the most part of Indonesian loan forms) by ada (usually shortened to da) 'at, in, on' or pigi (shortened to gi) : e.g., da rumah or ada rumah 'at home' or gi rumah or pigi rumah 'go home, home'. The forms which occur as locatives alone may also optionally be preceded by da (ada) or gi (pigi): dana sini 'here, at this place', gi sini 'here, to this place'.

On the Low level (which consists for the most part of $\mathrm{N}$ Javanese--see Sec. 5.2.1 below) there is little dropping of prepositions where the Pribumi speech does not also permit it. ${ }^{4}$

The functor yang or sêng (the Javanese equivalent of yang) is occasionally dropped in constructions where Pribumi speech requires it. (In this and the following sections we give a word-by-word translation in slanted lines following the citation.)

Malay. An example from standard Indonesian: tiga tambah dua 'three plus two' for tiga ditambah dua.

3. The term functor refers to forms which do not in themselves have any meaning other than that of specifying grammatical relations. The most important functor is Javanese séng (Indonesian yang) which links modifiers to their heads or which allows adjectives, verbs, and other parts of speech to occur in constructions reserved for nominals.

4. The High level speech has forms of Indonesian provenience. In Low level speech the forms are of Javanese origin, and the locatives are expressed by the various shortenings of ônô éng that occur in spoken Javanese. 
Kuwi nyonyah nganggo klambi ijo /that woman wear dress green/ 'The woman that is wearing a green dress.'

In Pribumi Javanese this sentence would run:

Nyônyah séng nanggo klambi ijo kuwi. /woman functor wear dress green that/

\subsubsection{Word Order}

The above citation also exemplifies the use of the word order demonstrative plus noun modified, a construction unknown in Pribumi Javanese speech and not considered correct in standard Indonesian (although it is common colloquial speech in Jakarta and Malaysia). This word order is almost as frequent in our texts as the normal word order for the Pribumi speech. An example (with a large number of forms of Indonesian provenience):

1. Itu waktu misiq umor brapa, ya. /that time still age how-much particle/ 'At that time, how old was she now?'

Occasionally we have examples of a modifier placed in front of the subject which in Pribumi Javanese is obligatorily placed before the predicate. For example, in the following citation moq 'only' is a modifier and rumae 'her house' is the subject. Mog should be placed before the predicate, but here it is put before the subject.

2. 0 itu moq rumaé mukaq situ /oh, that only her-house front there/ 'Oh, her house is practically across the street over there.'

In standard Indonesian as used by Javanese this sentence would also have the predicate modifier placed after the subject. Here hanya replaces moq:

0 itu, rumahnya hanya di muka, di situ. (Mog is the colloquial Javanese analogue of hanya.)

\subsubsection{Use of Verbal Forms where Pribumi Javanese Prefers a Nominal Construction}

There is a greater tendency for verbal constructions to occur in Peranakan speech than in the Pribumi Javanese speech. The following is an example of a sentence with a verbal clause in a context were a nominal clause would be obligatory in Pribumi Javanese.

1. Lungô sana sampéq anaq saya itu taq gôwô /go there up-to-thepoint-that child my that by-me was-brought/ 'I went there, even if it meant that I had to bring my baby with me.'

In Pribumi Javanese this sentence would run (substituting Javanese Ngoko for words of Indonesian provenience):

Léku lungô rônô nganti anaq kuwi taq gôwô /my-action-of going there up-to-the-point-that child my that by-me was-brought/

In this sentence léku is a nominalizing particle. 


\subsubsection{Lexicographic Peculiarities}

\subsubsection{Differences between Javanese Ngoko and Peranakan Speech of the Low Leve 1}

As we mentioned briefly in Sec. 5.0.1 Javanese $\mathrm{N}$ forms occur in Peranakan speech and function as a speech level analogous to the $\mathrm{N}$ level in Pribumi speech. We call Peranakan speech consisting of $\mathrm{N}$ forms the Low level and discuss it further in Sec. 5.2.1. However, Peranakan Low level speech differs from Pribumi Ngoko in a few small ways. These differences are:

(1) the absence of all honorific forms (KI or KA forms) or others corresponding to them in function:

(2a) Javanized Indonesian words, not used by the Pribumi Javanese community in Central Java (although found also in East Java), e.g., kerjô 'work', biyôsô 'ordinary', and perhaps others;

(2b) use of forms of Chinese origin which are not found in the Pribumi Javanese speech;

(2c) special Javanese words not normally used by the Pribumi community, ${ }^{6}$ e.g., kaku ati 'angry', swak 'not feeling good' (from Dutch), jenaqan 'name' (found in older Javanese 1iterary texts as we11), amèh, mèh 'future marker', etc. Some forms are used in a meaning unknown in Javanese or Indonesian, e.g., déwé in the meaning of 'be different', ajar in the meaning 'study a school subject', lagi in the sense of 'even':

1. dokteré lagi nèq ngunèni saya /the-doctor even when he-spoke-tome/ 'The doctor even said to me that...'

(3) the occasional inclusion of forms of Indonesian provenience which normally do not occur in the $\mathrm{N}$ speech of the Pribumi community. The Peranakan Low level speech is also marked by the occurrence of some high frequency forms of Indonesian provenience: tapi 'but', ndaq 'not', paléng 'most' (and

5. There is a large in-group vocabulary among the Peranakan. Many of these forms refer to foods, medicines, articles of everyday use, clothing, jewe1ry, and the like which are Hokkien (?) Chinese in origin; or religious, ceremonial, magical terms; or terms of commerce (including numbers), names of animals (from the calendar), and the like; all of which have to do with things brought from China. But there is also a fairly large vocabulary of everyday terms, a few of which are also known among the native Javanese, a1though most are strictly in-group talk: e.g., terms that refer to characteristics of actions (usually bad) ligyat 'clever and naughty', lihay 'skillful', mô sin 'crazy', dam 'greedy', au hau 'loyal to parents', put hau 'not loyal to parents, céng $\overline{1 i}$ 'fair, following the rules', ki cyaq 'greedy for food', nggô cyaq 'greedy for sex', ngeswéq 'persuade'; hwana 'Javanese', tenglang 'Chinese', etc.; words of everyday life: cyaq 'eat', say 'feces', pang say 'defecate', cyaq kha 'go barefoot', sé kya 'small child', né 'mother' (and most terms of relationships or pseudo-relationships), syo 'like someone', kamsya 'thank you'; terms of gambling and profit, pwaq 'gambling', suq nya 'bet'; cwan cyaq 'for things to be going well', mbé tit 'very, very profitable', mbé twi 'loss'; and many others.

6. These forms are probably normal in Javanese dialects from other areas, but they are unknown to our informants from Central Java. 
probably some others). The Javanese equivalent of these néng, ora (often pronounced oraq or raq in Peranakan speech), and dhéwé, respectively, also occur. ${ }^{7}$

As we shall soon see, Indonesian forms raise the speech level, but these forms tapi, ndaq, paléng are said to occur on the Low level as they do not raise the speech level (as we can determine by their distribution and informant reaction-Sec. 5.2.4). There are probably many other forms, such as tapi, which fail to raise the level. In order to obtain any notion of the level connotations of words of less common occurrence, we would need many more texts than we have. Lacking these, other possible procedures are reaction tests for likely candidates, and, of course, asking Peranakan speakers directly (although this does not yield consistent and trustworthy results). Good candidates are forms like kayaq gitu 'like that', sangkaq 'think', payah 'have a hard time'; etc.; and others like bajuq 'shirt', for which Peranakan informants state that they do not use the common $\mathbf{N}$ forms of the Pribumi community. Three other forms occurring regularly in the Peranakan Low level speech, also appear occasionally in the speech of Pribumi Javanese of Central Java: kan '(so-and-so) is the case, is it not?', lah 'predicate marker', and cumaq, cumèq 'only'. Javanese $N$ equivalents of these, raq, ôpô, and mong (méng, moq, méq), respectively, also occur in Peranakan speech but with less frequency than in that of the Pribumi community. Other Indonesian forms which occasionally occur in the Low level of Peranakan speech, may be regarded as slips of the tongue or switches (Sec. 5.4). Embedded in a series of utterances which are basically Low level, these Indonesian forms pass unnoticed, although by themselves they have higher level connotations. One example occurs in the remark by a great-aunt who has been talking on the Low level about her illness for nearly five minutes. The Indonesian form is underlined. (This sentence also illustrates the use of tapi 'but' and lah predicate marker, which has no level connotation.)

2. Tros njuqaan wês metu kabèh gôsônggôsông kaé. Pikir aku, "Yhô wés, mari," ngono. Yô és, isô, tapi biyasa lah. "Then all this reddish stuff came out. I thought, "Now I'm better." But it was just ordinary.'

In the majority of cases where Indonesian forms slip in, there is an explanation in the context (Sec. 5.4.6).

7. The choice of tapi over néng or ndaq (daq), ora or paléng (adjective) over (adjective) déwé has no level connotations, and we may thus say that tapi, ndaq (daq) and paléng are part of the $L$ vocabulary of the Peranakan speech. An example of daq in a clearly L level context:

Oraq Ban. Oraq sidô. Man dôngé. Kowé séng dikôngkôn. Iki mau anu, ngepôsnô. Iki ôpô. Kowé daq roh. 'No, Ban. Never mind. I meant for Man to do it. (Here, $\overline{M a n}$ ) I want you to go. (Take) this and mail it. This is it. (Not you)--you don't know how.'

In East Java the forms tapi, ndaq, and paléng occur in the speech of Pribumi Javanese. 


\subsubsection{Differences between High Level Peranakan Speech and Indonesian}

As we will explain later (Sec. 5.2.1) High level speech is marked by Indonesian loan words. In principle, the more Indonesian loan words, the higher the level. But even the highest level, with a large majority of Indonesian loan words, will differ considerably from Indonesian. First, the functors are almost all in Javanese. ${ }^{8}$ Further, even the best types of High speech will retain expressive Javanese forms of high frequency such as tô, lho, hé, lha, kôg, forms which are also used in the standard official Indonesian (and which, in fact, have found their way into the Indonesian of nonJavanese areas as we11), and Javanese lexical items for which the Indonesian word is not well known. Examples of Javanese forms used on all levels are: temôn 'ceremony of bringing bride and groom together after they have been kept apart for a certain period of time'; pengapit 'one who stands next to the bride in a wedding (bridesmaid, god-parents, etc.)'; payu 'for something to se11'; bocah 'child' (as opposed to anak 'offspring'); and many others.

Not only the functors, grammar, and Javanese lexical items make the H level Peranakan Javanese different from Indonesian, but there are other forms in Peranakan speech of the High level which are unknown in standard Indonesian. These are (1) forms from Indonesian dialects, (2) Indonesianized Javanese forms, (3) forms with $-q$ replacing a final consonant, and (4) dia.

(1) Forms from Indonesian dialects: Most of these are forms also found in colloquial Jakarta speech. Examples occur in the forms where /e/ replaces /a/ of a final closed syllable: dateng 'come', macem 'type', ndènger 'hear'. Other examples are forms like misih 'still', nyang (marker), belon 'not yet', barusan 'just now', kayaq 'like', pigi (short form: gi) 'to' (as in pigi sini ( $i$ sini) 'to this place' (standard Indonesian ke sini), pigi-(gi-)mana 'how', segini, segitu (or Javanized saggini, saggitu) 'this, that much'. There are other non-standard Indonesian forms, the dialectical origin of which we do not know, e.g., tinapi (napi) 'but).

(2) Indonesianized Javanese forms. These are of three sorts: (a) forms where Javanese /o/ is replaced by /a/: isa 'can' and sapa 'who'; (b) calques: saqini 'now', which is composed of saq plus ini 'this'. Saqini is a loan translation, of saqiki 'now', which is composed of saq 'time marker' plus iki 'this'; (c) Indonesian forms which are given the range of meanings of the Javanese analogue: the form ada (short form da) which has the meaning range of the Javanese equivalent ônô 'at, there is', e.g., da sini 'here' modeled on Javanese ônô kéné, whereas Indonesian ada only has the meaning 'there is'.

8. In the case of speakers who have a great deal of contact with standard Indonesian we find the occasional use of the linker yang and the affix -kan (also pronounced -ken) even in informal conversational speech. In the following citation the syntax is typical colloquial Javanese but also normal Indonesian. The marker -é (definite article) and prenasalization of an active verb are Javanese. The form kembang 'flower' is Indonesian and Javanese (although of Javanese etymology). The other forms in the sentence, including the market yang are Indonesian:

Kembangé yang mbawaq yang dari lakiq /the-flowers marker brings marker from man/ 'It is the groom's party that brings the flowers.' 
(3) Forms with -q replacing a final consonant: liyaq 'see' (Indonesian 1iat), ambéq 'take', and many others. 9

(4) dia: the third person pronoun. In Peranakan speech dia may refer to things and ideas as well as persons, whereas in schoolbook Indonesian dia normally refers to persons. (In colloquial Indonesian the broader usage also occurs. ${ }^{10}$ )

Further, the intonational and grammatical (including phonological) features of High level Peranakan speech are entirely Javanese, and these features give any utterance a Javanese feeling (cf. Sec. 5.1.1f.). As an example let us take the following remark made by a waitress to her employer. She is asking him if she should wear the pair of slippers that she has on, rather than the ones that were assigned to her (since they were too sma11). The forms of Javanese provenience are underlined:

Ini spatuné taq pakiqé ja pa /these shoes by-me let-me-wear only oK/ 'Sha11 I just wear these shoes?'

All the forms of the sentence are of Indonesian provenience except the functors -né 'the', taq 'first person passive' and -é 'optative ending'. There are other features of morphology, syntax, and word usage which make this sentence aberrant from any sort of Malay or Indonesian dialect: the alternation of the root pakèq to pakiq-, the shortening of saja to ja and apa to $\mathrm{pa}$, the word order demonstrative plus noun (also found in the Jakarta dialect), and the use of the question particle apa at the end of the predicate (instead of the beginning, as is normal in Indonesian). If we were to translate this sentence into standard Indonesian, it would read:

Apa saya pakèq spatu ini saja?

These grammatical features, however (except for the-order demonstrative + noun), are also normal in Pribumi Javanese (although, of course, the same sentence in Pribumi Javanese would employ entirely different lexical items).

No matter how high the level, a number of Javanese forms from the $N$ speech level are invariably inserted in any conversational style. These will be not only forms of high frequency like njog 'furthermore', ngko

9. The tendency to substitute $-\underline{q}$ for final consonants is very widespread, not only among Peranakan but also among speakers from other ethnic groups (including speakers of Malay dialects). We do not hive good information on Malay dialects in Indonesia, but a few random recordings of conversations make it very clear that this substitution of $-q$ for final consonants in rapid speech is widespread phenomenon. The substitution of $-q$ for final consonants in Peranakan speech of all styles is another example of the tendency to adopt rapid speech colloquial forms from Indonesian into all styles of Peranakan speech (Sec. 5.2.5). In East Java, Peranakan speech uses Indonesian loan translations of East Javanese dialectical forms (not known in Central Java): yaq apa 'how' (E. Jav. yôq ôpô); kerja apa 'what for' (E. Jav. gawé ôpô); dhateng 'from' (E. Jav. tekô); apaqô 'why?' (E. Jav. ôpôqô), etc. 10. For example in the following citation kluwarga brencana 'family planning' is referred to as dia:

Gawané njoq mengikuti kluwarga brencana, nèq dipikér, dia, ya, anaqé duwa. 'So, what they do is they follow family planning where you think it over. According to it [family planning], you have two children.' 
'later', nèq 'if, when, as for', etc., which have little Low level connotation for Peranakan or for Pribumi speech (see Sec. 2.1.1), but will also include forms from Javanese Ngoko which normally do not belong on the High level. We have no examples of High level speech in colloquial styles which do not show such a slippage. ${ }^{11}$ Further, there is constant code shifting (Sec. 5.4ff.). As a result, a speaker of Indonesian who does not know Javanese will be unable to follow any extended conversation, even on the highest level, although there will be individual utterances which are completely understandable. ${ }^{12}$

\subsection{Levels in Peranakan Speech}

\subsubsection{The Low and the High Levels}

The Low level consists of forms of Pribumi $N$ speech with the minor differences noted above in Sec. 5.1.4.1. The attitude of the Peranakan toward the Low level is very similar to that of the Pribumi Javanese toward Ngoko. Among Peranakan speakers one uses speech composed almost entirely of $\mathrm{N}$ forms (the L level) only to persons of lower status and with whom one is very familiar: members of the immediate family, ${ }^{13}$ people young enough to be one's children, people of one's own generation whom one feels to be of the same status and with whom one is intimate. (The question of who receives $L$ speech is discussed further in Sec. 5.3.1f.) However, Javanese Bôsô forms are not used in Peranakan speech. In the texts we have examined so far, we have found no forms which could be identified as Bôsô.

11. An example is the following sentence about where the groom gets the flowers from, spoken by the photographer at a pre-wedding dinner. The interlocutor is a complete stranger to him. The whole conversation is on the highest level in a colloquial style. (It only took place because the interlocutor was trying to get a tape recording.) Aside from the colloquial Javanese conjugation of the verb (dropping of di-) and the particle tô, everything is Indonesian, except the underlined portion which is pure Javanese and on the wrong speech level. The photographer is probably talking to himself aloud (5.4.2).

Tapi ambél dari sana tô. Ambél dari sana, nggôn wêdôqé tô? 'But they get them [the flowers] from there, don't they? They get them from there, from the bride's place, don't they?'

12. The citation in this section about wearing certain slippers is not understandable to people who know no Javanese, even though all of the contentives are of Indonesian provenience.

13. There is a great deal of variation among Peranakan as to the extent to which High is used. In families of strong non-Chinese orientation (those several generations removed from Totok patterns and who have had education in Dutch or Indonesian), Javanese is held in low esteem--it gives a connotation of inferiority. In such families a fairly high level is used to an overwhelming extent--even parents to children. Intimacy is not a factor in speech level choice for these speakers. They use Javanese only for addressing obvious proletarians (e.g., servants, petty vendors, hired laborers), in anger, or in talking to oneself. This tendency is strongest in East Java. 
To substitute for Krômô or Madyô Peranakan use forms of Indonesian provenience. At the Highest level, Peranakan speech contains something like a 90 percent Indonesian vocabulary. This speech still differs strongly from standard Indonesian, as we have noted above (Sec. 5.1.4.2). We call this type of speech with the maximum number of Indonesian loan words the HIGH LEVEL (H). Although High is a speech level like the Pribumi Madyô and Krômô, its sociolinguistic meaning differs from that of Krômô and Madyô in Javanese, reflecting the differences in fundamental ethics and Weltanschauungen of the Pribumi and the Peranakan Chinese communities. (We discuss this point further in Section 5.6, below.)

Further, Peranakan speech has no honorifics and practically no usage corresponding to Pribumi Krômô Inggil and Krômô Andhap. (The only overty differential forms we have found are the use of the $H$ level first person pronoun, saya and owe [masculine], in the meaning of 'yes'.) The fact that Peranakan do not use Bôsô vocabulary of the $K$, $M$ vocabulary nor the $K I$, KA vocabulary explains why Peranakan speakers of ten have no control of $K$ or $M$ forms, nor know how to use the honorifics. They tend not to know these forms because they have little occasion to hear them as they grow up. There are, however, exceptions, and some Peranakan have learned to control Krômô and Krômô Inggil very well, with some families having, in fact, assimilated entirely to Pribumi speech patterns. ${ }^{14}$ It is interesting to note that the Chinese in Wonosari, a small community south of Yogya, control speech levels (Madyô and Ngoko) as well as their Pribumi neighbors. But this group consists of only a handful of people who have spent their lives in Wonosari and grew up not at all isolated from these Pribumi neighbors.

\subsubsection{Medium Level}

Between the $L$ and the $H$ is a continuum of the MEDIUM LEVEL (Md) which is analogous to the Pribumi level, and similar to Madyô, in that there are innumerable varieties of Medium on a continuum between Low and High, just as there are innumerable varieties of Madyô ranging from near Krômô to near Ngoko. Thus, the Md level may have greater or less height--it may vary in height from a level verging on the Low (which we call Low Medium--LMd) to close High (which we call High Medium--HMd). A sentence may have only one or two Indonesian forms or a much larger number.

Phrase structure is entirely irrelevant to choi ae of which form is in Indonesian, and in fact, we get Indonesian-Javanese mixture within a single word or two-word phrase: danggoné 'at' (da Indonesian, nggoné Javanese); seratus sangangpuluh (seratus Indonesian, sangangpuluh Javanese), etc. (We discuss this point further in Sec. 5.6.1, below.)

14. Jewelry store owners, who deal largely with Pribuni, are mostly able to speak Krômô and some Krômô Inggil and use this or Madyô to their customers. (They frequently deal with monolingual Javanese customers.) In the following citation the shopkeeper (a Peranakan woman) starts in Krômô and finishes in Madyô:

Customer: Mangké kèq tumbas, pinten? (Sèwu telong atos tô?) 'If I buy it, how much is it? (Was it 1,300?)'

Shopkeeper: Menawi kadôs ngaten nggēh, kalēh welas men angsal. 'You can have one like that for on $1 y 1,200 . '$ 


\subsubsection{Determination of Speech Leve1}

In general, the factor that raises the level of speech is the occurrence of forms of Indonesian provenience. But it is not the number of Indonesian forms used that raises the speech level. Certain forms are much more powerful raisers of the speech level than others: certain forms clearly signal High; certain other forms signal at least Medium or possibly High; certain other forms only signal Medium; etc. The Peranakan speech levels thus operate in a way which is analogous to the Pribumi $\mathrm{K}, \mathrm{M}$, and $\mathrm{N}$ forms, where certain forms raise the speech level more than others (Sec. 2.1.1). However, there are differences. The main difference is that restrictions of occurrence are not so clearly adhered to as in the case of Pribumi Krômô or High Madyô; in Peranakan speech a form from the highest level may slip into the lowest level, and the highest level may contain words of the lowest level. In Pribumi speech even speakers who do not control Krômô consistently distinguish Bôsô from Ngoko. They do not insert Bôsô forms into speech on the $\mathrm{N}$ level, and when they are speaking Bôsô they are consistent in choosing certain Bôsô forms.

We determined speech levels for Peranakan speech in much the same way that we determined the Pribumi levels. We asked native speakers to listen to twenty selected utterances which we felt represented a variety of speech levels and mark them as to one of five speech levels. We were unable to get consistent differentiations of the twelve utterances in Md level but responses for the eight $\mathrm{H}$ and $\mathrm{L}$ level utterances were quite consistent. We then repeated the test for the twelve utterances on which we did not get unanimous answers, asking our informants this time to rank the utterances according to level. Although the rankings were not unanimous, they were consistent enough to enable us to distinguish which sets of utterances tended to be ranked higher than others, and we were thus able to assign one of five levels to all twenty utterances. We then took a text approximately an hour in length and had native speakers indicate impressionistically one of five levels for each utterance. Those ranked in the Md range we compared with the original twenty, and thus we were able to obtain a fairly accurate level assignment for all the utterances in the text.

Chart Six (p. 105) lists the percentage of times the Indonesian is chosen over' the Javanese for the ten most common items: (a) already (sudah over wés); (b) pronouns; (c) numbers; (d) adverb of place (sini, etc. over kéné, etc.); (e) there is (ada over ônô, etc.); (f) at (da over nang, etc.); (g) yes, or tag word (ya over yô); (h) demonstrative (ini, etc. over iki, etc.); (i) no, not (ndaq over oraq); ( $j$ ) but (tapi, etc. over néng).

One can distinguish five groups of forms in this chart, and this grouping is significant for determining how speech levels are communicated. For the first group, consisting of columns $a$ and $b$ in the chart (the forms for 'already' and the pronouns), Indonesian is chosen at the $\mathrm{H}$ level and only in 30 or 40 percent of the cases at the HMd and Md levels. Using Indonesian forms for these items in Peranakan speech is a clear indicator of the $\mathrm{H}$ level. In the next group, which consists of column $c$ (the numbers), Indonesian tends to be used at the HMd level,--that is, at a slightly lower level than for the forms in the first group (and even occasionally is used at the lowest levels), but on the whole, its use still strongly indicates the $H$ level. Third, is the group of forms (columns $d$ and e--adverbs of place and 'there is') for which an Indonesian choice is normal at any but the lowest 
CHART SIX

Approximate Percentage of Indonesian Choices for the Ten Items of Highest Frequency at Each of Five Levels

\begin{tabular}{|l|r|r|r|c|c|c|c|c|c|c|}
\hline \multirow{2}{*}{ Level } & \multicolumn{10}{|c|}{ items } \\
\cline { 2 - 10 } & a & b & c & d & e & f & g & h & i & j \\
\hline H & 100 & 100 & 100 & 100 & 100 & 100 & 100 & 100 & 100 & 100 \\
HMd & 40 & 30 & 95 & 100 & $?$ & 100 & 90 & 100 & 100 & 100 \\
Md & 40 & 30 & 40 & 85 & 85 & 85 & 75 & 80 & 85 & 100 \\
LMd & 0 & 0 & 10 & 20 & 0 & 50 & 50 & 45 & 40 & 50 \\
L & 0 & 0 & 10 & 10 & 0 & 0 & 15 & $25(?)$ & 30 & 10 \\
\hline
\end{tabular}

level (and there may even be a scattering of Indonesian choices for these forms at the lowest levels). Although they usually indicate a high level, they do not do so as clearly as the forms of columns a, b, or c. Fourth, there are the forms (columns $f$ and $g$, which represent forms for 'at' and 'yes') for which an Indonesian variant is chosen frequently at all but the lowest level and somewhere around half of the time even at the LMd level. When Indonesian forms are chosen, they raise the speech level only slightly. Finally, there is the group of forms where the Indonesian is of ten chosen even on the lowest level (columns $h, i$, and $j--^{-n o t '}$, the demonstratives, 'but'), and an Indonesian choice probably does not raise the speech level. We then counted by hand the choice of Indonesian or.Javanese made with each level: for what meanings the Indonesian was chosen over the Javanese am for what percentage of the occurrences at each level.

We did not include in this chart the group of forms of Javanese origin which occur in all speech levels, including the highest. These were forms of Javanese origin like the construction markers nèq 'if', mbèq (or its alternants ambèq, kambèq) 'with, direct object marker, etc.", and they occur at the highest level. If the Indonesian variant for these items occurred at a11, the level was marked by our informants as High, for its occurrence is the clearest indication of the $\mathrm{H}$ level. An utteranc? can be High, however, even if the Indonesian variant is not used for these items.

After we had established the groupings of Chart Six, we then looked for other common items where Indonesian choices cooccurred with Indonesian choices for these ten groups of items, and a Javanese choice cooccurred with a Javanese choice for these ten items. It turned out that the cooccurrence of Indonesian with Indonesian and Javanese was fairly consistent: there were Indonesian forms which cooccurred fairly consistently with Indonesian forms for the items in columns $a$ and $b$, and there were Javanese forms which cooccurred consistently with Javanese choices for the items in these columns; the same was true for the items in column $c$ and in the other columns. For the items in all these columns, certain Indonesian forms cooccurred consistently with Indonesian choices, and certain Javanese forms cooccurred consistently with Javanese choices. One could thus conclude that an Indonesian form indicates the same level as the Indonesian form with which it cooccurs, and a Javanese form indicates the same level as the Javanese form with which 
it cooccurs. In this way we developed lists of forms which indicate level. Further, we looked for items where a Javanese form cooccurs with the Indonesian forms referred to by Chart Six. The reasoning was that, if a Javanese form cooccurs with an Indonesian form which clearly indicates a certain leve1, then if that Javanese form is replaced by an Indonesian variant, the Indonesian variant would clearly indicate that level or a higher one.

List Five shows forms where a Javanese choice cooccurs with an Indonesian choice for all ten items of Chart Six. We conclude that a choice of Indonesian for the items on this list clearly indicates the $\mathrm{H}$ level. List Six shows items where the choice of Indonesian cooccurs with sudah and the choice of the Javanese cooccurs with wés. For these items, choice of Indonesian also clearly indicates a $\mathrm{H}$ level, but not as strongly as in List Five. List Seven shows the items where the choice of Indonesian cooccurs with the Indonesian numbers and the choice of Javanese with the Javanese numbers. The Indonesian choice for these forms indicates the $\mathrm{H}$ or Md level. List Eight shows the items where the choice of Indonesian cooccurs with the choice of Indonesian items for the adverbs of place and the form meaning 'there is'; and the choice of a Javanese form cooccurs with a Javanese choice for the adverbs and the form meaning 'there is'. These forms have the same level indication as the adverbs of place and the forms meaning 'there is' and thus occur at any level above the lowest. They indicate speech higher than the L level (LMd or above).

Finally, we had native speakers judge speech levels in the other texts we had gathered (originating from only two additional hours of conversation) and then checked the results of this hand tabulation against them. We found that, with only one exception, the other texts bore out our hand tabulations. Thus, Indonesian forms which we had thought tend to occur only on the $\mathrm{H}$ levev (those from List Five) did indeed for the most part show up in sentences identified by our informants as High or High Medium and not in lower level sentences. Forms that we had thought occur on High Medium (from List Six)

LIST FIVE

Items for Which an Indonesian Choice Indicates $\mathrm{H}$ Level Most Clearly*

Indonesian

kaloq**
dengan, sama**
ya sudah
sebap
saja
gimana
baru
pigi
sendiri
punya

Javanese

nèq**
mbèq, etc.**
yô wês, wês bèn, etc.
wông
whaé
piyé
lagèq
lungô
dêwé
dhuwé

Translation

if, as for

with, object marker

all right

because

just

how

just now

go

alone, the most . .

possess

* We do not list all of the Javanese and Indonesian variants for these forms which occur in our materials.

** There is a very strong tendency to choose Javanese forms for the first two items on this list. Even when every other item on the list is in Indonesian we may find Javanese forms chosen for them. 
Items for Which an Indonesian Choice Indicates $\mathrm{H}$ Level only Slightly Less Clearly than the Items in List Five Do

\begin{tabular}{ll}
\multicolumn{1}{r}{ Indonesian } & \\
sudah & wés \\
nanti & ngkovanese \\
jadi & dadi \\
mau & arep, mèh, apé \\
berapa & pirố \\
saya (owé), dia & aku, dèqé \\
situ & kowé \\
ndaq papa & ra pôpô \\
sapa & sôpô \\
suruh & kôn
\end{tabular}

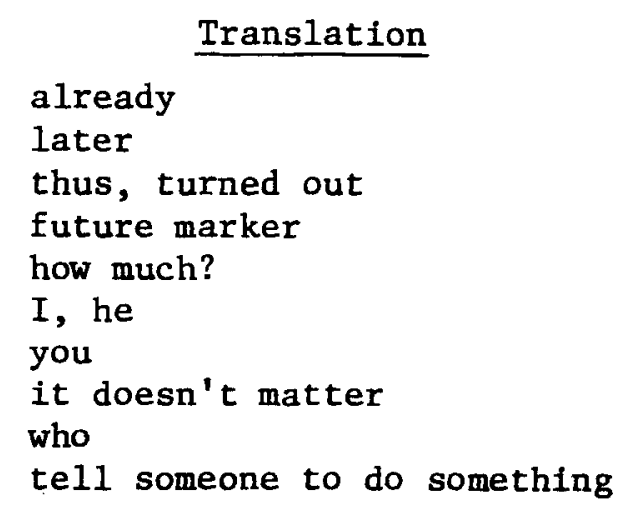

\section{LIST SEVEN}

Choices Which Indicate a $\mathrm{H}$ or Md Leve1

Indonesian
belon
dulu
misih
mémang
da
isa, bisa

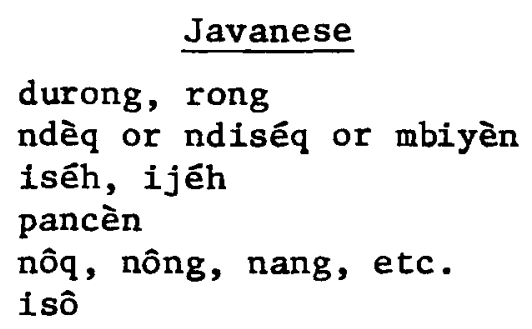

\author{
Translation \\ not yet \\ first or before \\ still \\ really \\ use, with \\ can
}

\section{LIST EIGHT}

Choice of Indonesian Which Indicates a IMd or Higher Level

Indonesian

sini, situ, sana

saqini

ini, itu

gini, gitu

apa

kaya

ada
Javanese

kêné, rêné, etc.

saqiki

iki, kaé, iku, etc. ngéné, etc. ôpô kôyô ônô, ènèng
Translation

here: there

now this, that this way, that way question particle like, as there is

did occur only on $\mathrm{H}$ or HMd levels. Indonesian forms from List Seven occurred in $\mathrm{H}$ or in $\mathrm{Md}$ sentences; and Indonesian forms from List Eight in sentences which informants had identified as LMd as well as on higher levels. Our one exception was the demonstratives. We originally encountered the se in sentences identified as $\mathrm{L}$, but they did not occur in $\mathrm{L}$ sentences in our other texts. We therefore believe that the original identification of sentences with Indonesian demonstratives as $\mathrm{L}$ was mistaken. They should probably have been identified as LMd. 
We did not carry on any informant perception tests, and our results must be considered tentative. In any case, the forms in these lists are not hard and fast indicators of level. We only mean to say that at a given level there is a tendency to choose the Indonesian over the Javanese analogue for certain lexical items, and mutatis mutandis, the occurrence of certain choices thus indicates the speech level. In East Java these rules do not apply. Indonesian forms are used there much more widely and at a much lower level.

\subsubsection{Stylistic Variation Apart from Speech Level}

Traditionally neither Javanese nor Indonesian have functioned as languages of learning for the Peranakan and were never used for serious exposition or 1iterature. (Dutch or Mandarin fulfilled these functions.) This situation has changed in the past thirty years, but a large portion of the population still knows only colloquial or substandard Indonesian forms. Thus, on the $\mathrm{H}$ level, even the most careful speech will of ten show forms of Indonesian provenience which are prohibited by the school books and do not appear in serious writing: barusan 'just now' (for standard baru), belon 'not yet', nyang (linker--for standard yang), and many others. For the Peranakan, Javanese is even less a language of literature than Indonesian, and in our texts Javanese forms of the slow, careful-speech styles (Sec. 4.5) simply fail to occur. Rapid speech forms are invariably chosen for forms of Javanese provenience. The method for formalizing speech is to raise the leve1--i.e., substitute Indonesian forms or (for some speakers), switch to Dutch. Thus, as opposed to the Pribumi community, the Peranakan traditionally have had no formal literary styles apart from speech level (or for some groups, a switch to Dutch).

This situation has changed to some extent with the post-war generation. For the younger generations, who have received education in Indonesian, formal standard Indonesian functions as a code separate from conversational styles which always contain some Javanese forms. Formal Indonesian occupies much the same function as standard Indonesian in the Pribumi community (Chapter 3). Although we know this from personal observation, we do not have any recordings which show a switch to standard Indonesian on the part of speakers educated in Indonesian. The example in footnote 10 (p. 101) shows an attempt at formal speech on the part of a speaker with no Indonesian education. In addition, for Peranakan standard Indonesian also serves the purpose of communicating with non-Peranakan with whom Low (i.e., Ngoko) cannot be used (cf. Sec. 5.3.5).

\subsection{Pragmatic Analysis}

The Peranakan in our experience tend to regard Javanese as a language of the peasants and the proletariat. As the Peranakan are not normally participants in the Pribumi literary, theatrical, religious, or other cultural traditions, Javanese has no function for them other than in communicating with the lower classes of the Pribumi or in conversations where one need feel few inhibitions. Peranakan speakers typically react to Javanese in much the same way as speakers of unwritten languages or non-standard dialects do elsewhere in the world: Javanese cannot be used for serious purposes; it can be spoken in any old way; and it is not suitable as a code with an out- 
sider whom one respects. They do not think of themselves as speakers of Javanese. ${ }^{15}$ Accordingly, status is the main pragmatic factor which dictates speech-level choice for the Peranakan: relative age of the speaker and addressee, educational level of the families from which the participants come. Our limited materials bear out this impression: based on the identification of the participants in the conversations which were recorded and the comments made by our informants, status factors determine speech-level choice. Intimacy seems to be a secondary factor. People who are intimate--who feel at ease with one another, may use Low (pure Javanese) or may use High Medium or High depending on the orientation of the families of the participants. Families in which the head of the household has a high level of education in Indonesian or Dutch tend to speak High or High Medium among themselves, and the young people in the family tend to follow such patterns with their friends and intimates (even those who come from families that use Low among themselves). Thus the speech-level choice depends primarily on the view the speaker has of himself and his interlocutors. There is one exception to this: in groups of intimates or pseudo-intimates which may include Pribumi, pure Javanese (Ngoko--i.e., Low) is the code, no matter what the educational level. For example, among students at Gajah Mada and at IKIP Sanata Dharma in Yogya Ngoko is the code, and Peranakan who use High or Indonesian put themselves outside the group. Since oftentimes the younger generation has more Indonesian or Dutch education than the older generation, young people have a stronger tendency to use Indonesian forms than their elders, and we of ten find unequal exchange (cf. 5.3.2). Further, since choice of Low asserts low status (see our discussion in footnote 13), there is a tendency to speak up (use a higher level) to older generations.

In addition, we find that few speakers who use a level above Low do so consistently. All of our speakers who use High or Medium to their interlocutors occasionally intermix lower level sentences, even though, as far as we can determine, none of the reasons for code-siwtching are prsent (Sec. 5.4.4 below). (Exceptions, of course, occur in our materials when speakers utter only one or two sentences in the course of the recording.) The following citation exemplifies this type of slippage. The speaker slips to Low, but when asked to repeat, he goes back to High, his normal code:
A. Di dadèqno $s i j i$, maq?
(L)
'Are they put together, grandma?'
B. Hem? 'Ha?'
A. Jadiken satu. (H) 'Do they put them togethacr?'

\subsubsection{Mutual Exchanges of $\mathrm{H}$ Level or Md Level Speech}

Mutual High or Medium is exchanged in our materials by adults who are of the same age and consider each other and themselves as educated, and also by adults who are of different generations and not intimate (although sometimes related by marriage). In none of our cases is there strict adherence

15. The Peranakan response to Wilmott's language survey (1960: 112) reflects this attitude. In response to his question, 'What language(s) are used in your home?' the responses from Peranakan (with no China-born parents) were as follows: Chinese, 16 percent; Dutch, 22 percent; Indonesian, 82 percent; Javanese, 19 percent. Any survey based on performance would surely have revealed that nearly all Peranakan speakers, in fact, used Javanese in the home most of the time. 
to the $H$ or Md level. For example, in one case, where the speakers are separated by a generation gap, the older uses High around 60 percent of the time, and otherwise uses Medium or Low. In another case of speakers separated by a generation gap, the older uses High in about 30 percent of the utterances and otherwise used Low. The younger uses High around 80 percent of the time and otherwise Medium or Low, in both cases. In cases of speakers of the same age, the percentage of High varies from 40 to 90 . With our 1 imited materials we could not correlate our figures with sex or generation. (We also have many examples of High spoken to small children [Sec. 5.3.4].)

\subsubsection{High or Medium Reciprocated by Low}

We have several cases of High or Medium reciprocated by Low. In all of these the participants are intimate and the recipients of the High or Medium are old (above 65). For example, we have two cases of speakers who use High or High Medium to their great-aunts and receive Low from them, and in both cases the aunts had had Indonesian or Dutch education and the grand-nephews are college graduates. In the speech of the nephews there is a 10 percent occurrence of sentences which are purely Low and at least as many sentences again on a Md level somewhat below High Medium, and the aunts in both cases reciprocate with Medium or High on several occasions. Another example is found in the conversation of a woman aged in her nineties (illiterate) with a family, whose members range from people in their fifties down to sma11 children, and who are familiar with her, though not related. The head of the family, a 35-year-old man, consistently speaks Low to the old woman, but the rest of the family (including the head of the family's mother) use High or High Medium, with about 15 to 20 percent of the sentences dropping to a lower level. The woman speaks Low to everyone, except for some occasional forms in High.

\subsubsection{Exchange of Low}

The $\mathrm{L}$ level is often exchanged between people who are intimate, whether or not they are of the same generation. However, age is a barrier in itself, and people who are separated by a large generational gap must be much more intimate to exchange Low than people who are of the same generation (cf. Sec. 5.3.2 above). The following are examples of people who exchange Low in out materials: parents and children; husbands and wives; siblings; school friends; cousins. In these cases, however, we find occasional H or HMd sentences, since they involve people who have Indonesian or Dutch education.

We have some examples where there seems to be doubt on the part of the participants as to how they should speak, and we find switches from Low to higher levels and back. For example, in one case a nephew used fourteen $\mathrm{L}$ sentences and six $\mathrm{H}$ sentences to an uncle he did not know well and received eleven $L$ and four $H$ sentences.

\subsubsection{Speech Leve1 Used to Children}

Many parents speak High or speak at a level above Low to small children (but not consistently) as a way of teaching the $H$ forms. For example, the following remarks were addressed to a child of around two years, in a family 
where Low (pure Javanese) is exchanged. H forms are underlined. The mother's sentence begins as Low and switches to High after the first word:

$$
\begin{gathered}
\text { Grandmother (holding the child): Aku ôjô mbôq ômpôli, yhô? 'Now don't } \\
\text { go and make wee-wee just when I am holding you.' } \\
\text { Mother (to child): Saqiki kaloq is bilang, yha, ayo. 'This time, if } \\
\text { you are going to make wee-wee you tell, ok? Come on!' }
\end{gathered}
$$

We have recordings of children as young as six. These children use levels above $\mathrm{L}$, but we do not have the kind of texts which would prove that they control these levels. No doubt there is a certain degree of control (as is the case of Pribumi children who control Madyo--Sec. 2.4), but there is a relatively large number of forms involved, and it would be interesting to see at what rate and to what extent children acquire control over them all. Citation 5 of Sec. 5.4.4 shows an exchange between a six-year-old child and her parents where the child answers in High when addressed in High. The same child once asks her mother for something in Low and at another time at a level above Low.

\subsubsection{Communication between Peranakan and Pribumi}

Popular belief has it that the Peranakan do not use levels above Low when speaking with Pribumi. However, our own recordings and experience show that this belief is false. There are many groups to whom it is unthinkable to use Low, and the forms employed by the Peranakan when they speak to such people are something other than Low. The form employed varies with the competence of the speakers. Those who have been educated in formal Indonesian use Indonesian for conversing with anyone who is too high in status to address in Low. For example, a student with his teacher or with Pribumi students whom he does not know well would use Indonesian. Or, a salesman of expensive items or who is in a business dealing in luxury goods would use Indonesian to all customers, and in such stores Peranakan customers would use Indonesian to any salesman (Peranakan or Pribumi). A further example would be when restaurant owners speak to customers. If the Peranakan do not know formal Indonesian they use the highest level available to them. Some speakers use Dutch or Indonesian 'improved' by Dutch loan forms for these purposes.

There is a feeling that the types of speech between pure Low and pure Indonesian are appropriate only for communication with other Peranakan Chinese. Javanese with Indonesian loan words functioning as a speech level is in-group usage, and Peranakan address Pribumi either with pure Javanese (usually Ngoko) or pure Indonesian.

Further, it is worth noting that the Peranakan tend to use Low to a larger variety of strangers than most Pribumi. In conversations with people perceived to be lower in status (employees, vendors in the market, laborers, and the like) Peranakan use Low, whereas the Pribumi would tend to use Madyô (at least Low Madyô). ${ }^{16}$ Pribumi of such status who are addressed in Low (Ngoko) usually answer the Peranakan in Madyô, although we have examples where the Pribumi interlocutor is addressed in Ngoko and answers in formal

16. Not all Pribumi, however, do use Madyô. There are some old-fashioned priyayi who avoid Madyô entirely and use Ngoko to anyone they clearly perceive to be lower in status to themselves. 
Indonesian (probably as a result of his feeling that he should not be addressed in Ngoko--Sec. 3.4.1). An example of a typical exchange is the following citation from the speech of a Pribumi rice vendor and his Peranakan customer. M forms are underlined. Everything else is Ngoko (= Low):

Customer: Duwité dadi pirô, Pin? 'How much does it amount to, Pin?'

Vendor: Yatrané? Kanggé patlikor nggéh . . . swidaq, pôtông kaléh ôn, yoq, ngarani kulo kirang kaléh ôn, yoq. 'How much? For twenty-four it would be um, sixty, taking off two ounces [for the bag], Mrs. Count me as taking off two ounces, Mrs. [I.e., sixty is what she is taking off.]

Customer: Nèq duwité satos, rông èwu patangatos, séng seringgét péng patlikor pirô? 'If it were a hundred it would come to 2,400 . The other two and a half time twenty-four is how much?' [I.e., the rice costs $102,50$.

Customer's child: Berasmu putêh ôpô kunéng? 'Is your rice white or yellow rice?'

Vendor: Kunéng! 'Yellow!'

Child: Èlèq! 'It's lousy!'

Vendor: Niki umboq sendanten. 'This is all "umbuk" [kind of rice].'

\subsection{Code Switching}

\section{4 .1 In Quotations}

A common rhetorical device in Peranakan speech is direct quotation, which seems to be used much more frequently than in English--i.e., a sentence like 'He said he would come' is expressed, 'He said, "I'11 come."' ("Arep tekô," gitu.) The quotation is normally given on the level that the sentence supposedly was uttered. In this way Peranakan speech works like Pribumi speech (Sec. 3.1). Thus, on the $H$ level, as in the sentence just cited, the quotation is in Low. The example comes from a student talking to his great aunt, with whom he uses High Medium or High consistently. Another example, is the following citation, where the student talks about why he did not come by car:

1. Tor lagi dipikérpikér, nèq dibawaq sini malem, nanti, apa, "dadiné ra nônô nggôné." Ndaq ada tempaté tô. "Then I thought if I bring it here at night, umm, (I said to myself), "So there won't be room to park it." You know, there won't be any place to leave it.'

The portion we translated I said to myself is expressed in the Javanese original with the switch to Low. A quotation may be on any level (whichever level is appropriate). In the following example, a lady quoting her doctor uses High; but as the doctor's speech itself contains a generalized proverb, Low (Sec. 5.4.3) is used for this. The lady is speaking on the Md level:

2. "So, saqini anaque brapa"? -- "Dlapan." -- "0, nyatané ndéng nèq tenglang itu, ya, 'nèq sugéh anaq, sugéh putu,' ya, So?" muni ngono. "Mrs., how many children have you got now?" -- "Eight." -"Oh, like what the Chinese also say, 'Rich in children, rich in grandchildren,' isn't that so, Mrs.?" That's what the doctor said.' 
On the other hand there is a tendency to raise the level of the quotation when one is speaking on the Md or $H$ level if the quotation is in Low. (Cf. a similar phenomenon in Pribumi speech, citation 3, Sec. 4.2.) In the following citation, for example, a student speaks to his great-aunt in Medium but quotes a husband's words to his wife in Low. The quotation actually contains forms in High which do not belong in the speech of a husband to his wife. The $\mathrm{H}$ forms are underlined:

3. Ngkukungé ndaq dateng. "Yô wês kono. Ésoq nèq nèh mangkat, yô, sana nang ksana." 'Ku Kong [mother's uncle] is not coming. (He said to his wife) "You go ahead, if you want to go tomorrow."'

The context of Md speech causes the speaker to mix in $\mathrm{H}$ forms into the quotation which should be in Low.

\subsubsection{Code Switching in Talking to Oneself (Non-Directed Speech)}

A remark which is not addressed to anyone in particular (although it may be meant to communicate something) is put in Low. This device is analogous to the device we called non-directed speech in our discussion of Pribumi switches (Sec. 4.2).

In Peranakan speech (as in Pribumi speech) a good portion of utterances involve non-directed speech. We do not know how the frequency of use of this device compares in Pribumi and Peranakan speech. However, both communities use it often, and, it seems to us, much more than English does. The types of subjects or attitudes for which Peranakan speakers use non-directed speech are very similar to those which elicit non-directed speech on the part of Pribumi speakers. Non-directed speech used by Peranakan with interlocutors with whom they are on non-L terms is often interspersed with directed Indonesian forms to keep the interlocutor involved, much as non-directed speech with Bôsô interlocutors is often interspersed with directed Bôsô forms in Pribumi speech. [In this section and its subsections we put nondirected speech in parentheses, as was our convention in Secs. $4.2 \mathrm{ff}$. and underline directed Indonesian forms.]

(Yhô ndaq! Nèq dèqèné manèh, kôncôné kôyô ônô ôq, anu, tergantong kôncôné ôq) yha. (Kôncôné sandangané apiqapiq, mèlu apiqapiq) yha. ' (Oh yeah! It is all the more so in his case, with friends like that. It all depends on his friends), you know what I mean? (If his friends wear nice clothes, he will follow suit) you know what I mean?

\subsubsection{Functions of Non-Directed Speech}

As in Pribumi speech Peranakan non-directed speech is typically used when uttering one's own thoughts aloud. For example, in the following citation one lady tells another lady about birth control pills in High Medium or High. She expresses her own feelings in Low.

1. Sebabé takuté itu (wés kadong ngombé, ora ônô obaté, raq cyaq lat) ya tô, So? 'Because I was afraid that (suppose I start taking one brand of pills and then run out, what then?) isn't that so, Mrs.?'

Another example: 
2. Nèq nuruti wông urip itu angèl. (Séng ora nduwé, kepéngén nduwé. Séng kakèen, môh.) Wông kaya gitu itu, yha, mokal. 'It's really hard to do what you want to do in life. (Those that don't have any children want them. Those that have too many don't want them.) So, if that't the way it is, it is impossible [to have what you want in life].'

Another example of this type of non-directed speech is in proverbs. Cf. the example sugêh anaq, sugêh putu 'rich in children, rich in grandchildren', of citation 2 in Sec. 5.4 .1 above. Quoting someone else's opinions also is done in Low. For example in the following citation one lady tells another what her mother used to say:

3. Mamah ndèq duluô yha gitu. (Tau mèlu wông ki oraq pôpô. Nèq oraq tau mèlu wông ki, wés, wông ...) Ini, ya, ntoq wông sana. 'Mother used to say that, too. (If they [servants] have worked before, it's all right. But if they have never done it before, never mind, because....) I just recently got a new one [servant] back home. . .

Discussion of one's personal feelings is usually done in non-directed speech. In the following citation a lady talks in Low about her eyes to another lady whom she had been addressing in Medium:

4. (Môtô dô lôrô kôq pilek yhô . . . Aku ki daq tau, môtô lôrô gèq itu Tho tuôné.) '(I can't understand why my eyes got infected with this cold of mine. I never had an eye infection. It's the first time in my whole life.)'

Non-directed speech is also used in addressing several people whom the speaker adresses individually with different levels. For example, in the following citation, a lady addresses a group of ladies, to some of whom she speaks Low and to others High or High Medium. But this remark is made as if she were thinking aloud:

5. (Nèq wés ônô kluarga brencana, anaqku ra semono akèé ôq.) 'If there had been family planning, I wouldn't have had so many children.'

Non-directed speech is also a device to avoid saying directly something which one is reluctant to communicate. In the following citation the speaker half apologizes for eating when the rest of the company is not:

6. (Na, oraq gelem ngono ôq ngsoné. Malah aku séng kôn mangan.) 'Hm, the lady doesn't want any. Here I am trying to get her to eat and she tells me to eat instead.'

We commonly find non-directed speech when the speaker is searching for the right words. The following citation comes from the conversation of a student with his great-aunt (with whom he uses High Medium). The student was asked by his great-aunt why kô Un did not come, a source of possible embarrassment, so he fumbles:

7. Nha, yha, tapi (piyé yô) yha, wông soalé Kô Un itu tanyaq gitu 1ho.. 'We11, yes, but, umm, (how shall I put it) you know, the problem is Kô Un asked me the following. .'.' 


\subsubsection{Lowering or Raising Speech Level Because of Subject Matters Which Tend to be Discussed on a Certain Speech Level}

The use of non-directed speech for certain types of subject matter has given rise to the use of $L$ level in general for these subjects. For example, in the following citation A and B talk in High Medium, but A switches to Low when she talks about her own child-bearing experiences, although she still seems to be speaking directly. The L sentences are in parentheses:

1. A: (Kèrikèri metu Pekéng. Dasaré subor ki piyé. Teros dadiné waé.) '(Suddenly Pekéng was born. Because I'm so fertile. What can I do. They just keep coming.)'

B: Tin, itu lho, adiqé. 'Tin, dear, that is for you.'

A: Heqe. Sudah. Ayo tô, So. 'Yeah. No thanks. You go ahead, Mrs.'

B: Kenyang banget tenan. Tadi mau pigi sini wông sudah makan. 'I'm really full. I ate before I came.'

Similarly, two ladies who are related by marriage use Medium to one another, but when they talk about the daughter of one of them they switch to Low. Their speech seems to be directed at each other, but the code is that of non-directed speech:

2. A: Rupané hèlèq déwé. 'She is the ugliest one.'

B: Ayu ngono ôq. 'I'd call that pretty!'

A: $\bar{E}$ ayuné nyô ôpô? Iki! 'Come on! You must be. kidding!'

Sarcasm is usually expressed with Low. It is as if the speaker were uttering his own thoughts aloud, as in the following citation where an old woman gossips about a dead couple whose children failed to respect their memory. Her addressee, a young woman who usually speaks in High Medium to her, responds with sarcasm in Low:

3. A: Anaqé Bah Kông, Nyah Kông, Bah Kông Péng iku sepuloh 1 ho ngono. Cumaq Ang Lina iku séng apéq. Ang ambiqan Lina. 'Mr. and Mrs. Kong, Mr. Kong Péng had ten children. Only Ang Lina turned out any good. Ang and Lina.'

B: Cyamiq, cyamiq, Maq, yhô. 'That's pret'y good going, isn't it, Grandma?'

Also when giving reassurance or consolation a speaker may shift to Low or at least shift downwards, talking to the addressee as if he were a small child. In the following citation an old woman worries whether people will say prayers over her grave. Her interlocutor reassures her on a level quite a bit lower than the level she normally employs.

4. A: Daq ndenger. Ora disembayangi mbèn disembayangi daq roh. 'I just don't know. If they will forget to pray for me or will pray for me, I don't know.'

B: Wés lari sini, Maq, yhô? 'You just turn to us, Grandma.' The subject matter may also cause a shift to High (underlined), for example, in school matters: 
5. Friend: Fi Fi sekôlah? Kowé és sekôlah? 'Do you go to school Fi Fi? Do you go to school yet?'

Fi Fi's mother: Sudah sekôlah, belon. 'Do you go to school yet, or not?'

Fi Fi: Sudah 'Yes.'

Mother: Kelas berapa? 'What grade are you in?'

Fi Fi: Satu. 'First.'

The speech level is raised also for subject matters of importance. Raising the speech level may then serve to underline what one was saying. (Cf. the parallel phenomenon in Pribumi speech, Sec. 4.3.2.) For example, in the following citation where a father upbraids his child for eating something that he was not given permission to touch, he uses High for emphasis:

6. Taq taroq sini hé, mboq pangan. 'Hey! I was the one who put that that here. What are you doing eating it!'

Another example of a similar switch to High is when a Chinese prostitute who speaks Low to her police protector, siwtches to High to defend herself against an accusation someone had made againse her:

7. Wah saya brani sumpah. Saqiki ngéné waé. Naq aku sampèq ada kejadian seperti ini, saya mati rejekiné. Nèng nèq séng ora ki, mèn baléq karo wongé séng ômông mèn mati rejekiné. Hee, saya gitu aja. Saya brani didu, sekarang, sekarang ja, ya, mari goncèngken. 'I dare to take an oath. Right here and now. If I ever have done this thing, may I never earn money again. But if I did, God damn it, let it happen to the guy that accused me. That is just what I want to do. I dare to confront him. Now. Right now. Take me there on your bike."

\subsubsection{Code Switching to Keep Two Conversations Apart}

We have some examples of slippage from one level to another under the influence of the context. In the following citation the speaker reprimands a child (in Low) and at the same time is offered something to eat by a person to whom she usually speaks in Medium or High. She refuses in Low under the influence of the remark she just made to the child, and then repeats again in High:

1. Dikandani wés nesu caé. (Ora. Aku warek banget kôq.) Dah kenyang.

'You say anything to that child and she goes into a tantrum. (No.

I am very full.) I have had enough, thanks.'

In the following citation A usually speaks to B in Low and B to A in High, but under the influence of $B^{\prime}$ s speech $A$ switches to High (underlined). In the next sentence she goes back to Low:

2. A: Kowé séq dôdôl nèng pasar? 'Do you still sell in the Market?'

B: Saqini, yha, ndaq lagi. 'I don't these days any more.'

A: Nggaq lagi? 'You don' $t$ ?'

B: Wông sekarang ndaq payu kôq. 'You can't make money these days.' 
A: Ki, nèq ora kendel yô . . yô piyé yô. Angèl lah. 'These days if you aren't brave, well, what else can you do, it is hard.'

\subsection{Choice of Level as an Indicator of the Addressee}

As illustrated in citation 1 of Sec. 5.4.1 above, choice of speech level is a clear enough indicator of a direct quotation with no other markers. Similarly in direct address there is often no signal of who is being addressed other than the choice of speech level. This is especially striking to a Westerner because the speaker does not necessarily look at the person he is addressing. (Cf. footnote 1 to Chapter 4, Sec. 4.2, and the second citation of Sec.4.1.) In the following citation, an older woman invites a friend to come sit next to her (in High) and orders a young man to get another chair (in Low). Each person knows who is being addressed from the speech level employed. H sentences are underlined:

older woman: Lho ya kôq njoq ; . déq. 'Oh, hey, why aren't you [sitting over here?]'

Friend: $\quad \frac{\text { Ya sudah. Taq duduq sini. 'Never mind. I'll just sit }}{\text { over here.' }}$

0. W. (to young man): Pancèn kéné panggônanê yhô? Ngko tô. 'This was where she was sitting before, wasn't it? Go on, now. [Get another chair.]'

\subsection{Comparison of Peranakan Speech with Pribumi Speech}

The Peranakan and Pribumi communities may be compared from the point of view of formal speech differences and, to a tentative degree, from the point of view of differences in the ethnography of communication. With regard to formal differences, it is possible for us to come to reliable conclusions, even on the basis of the few texts which we have studied. We have already listed some of the grammatical and lexical differences (Secs. 5.Iff., above), and we can also reach solid conclusions about the formal features of the way Indonesian forms are used in the two communities. About other differences we can only come to tentative conclusions, as we have a wide range of recordings only for Pribumi speech and not for Peranakan s-eech.

Let us begin by reviewing the different functions of Indonesian in both communities. As stated in Chapter 3, Indonesian basically has the same types of functions in the Pribumi community that High forms are typically said to fulfill in diglossic communities. Indonesian is thus used for certain subjects or in certain settings, and is also used as a language of prestige--as a means for asserting certain rights or a certain status. In addition to these typical functions of the high language of diglossic speech community, Indonesian performs the special function among the Pribumi of being a device for avoiding Javanese, where its use would enforce the choice of an unacceptable speech level or an unacceptable honorific (Secs. 3.4ff.). In the Peranakan community, Indonesian occupies an entirely different role. It has a speech level function, somewhat analogous to Bôsô for the Pribumi. This function arises from the Peranakan attitude toward Javanese as a code suitable only for use with lower classes or with intimates (cf. Sec. 5.3, above), which means that, for them, Indonesian functions first as a speech level and 
second, as a high level of diglossia. Also, Indonesian is not available for the Peranakan as a device for avoiding speech level choice (since in Peranakan speech it is Indonesian itself that raises the speech leve1).

\subsubsection{Differences in the Form Which the Indonesian Admixture Takes}

The difference in function of Indonesian in the two communities leads to totally different ways by which they use forms of Indonesian provenience. These differences manifest themselves in the grammar of Indonesian forms and in the choice of which particular items are to be in Javanese and which in Indonesian. In Pribumi speech, where Indonesian functions as a high speech of the diglossic situation, there is a tendency to put whole phrases or sentences in Indonesian, for it is important for Indonesian to be recognized as such; in Peranakan speech, where Indonesian forms indicate a higher speech leve1, the choice of Indonesian as against Javanese forms has nothing to do with the phrase structure of the sentences. Thus, in Pribumi speech, in a switch from Indonesian to Javanese or vice versa, almost always an immediate constituent will be in one code and another imnediate constituent will be in the other. As the switch from Javanese to Indonesian in Peranakan speech has no connection with the phrase structure, any word at any point may be put in either code. In fact, a single word or phrase of two words may be in both codes: e.g., rông kali 'two times' (rông Javanese, kali Indonesian); ndèq kemarèn 'yesterday' (ndèq 'past time' Javanese, kemarèn 'yesterday' Indonesian). This phenomenon is exemplified by citations 2 and 3 below, where the phrase structure is marked by square brackets. Further, in Pribumi usages of Indonesian, except where Indonesian functions as a method for avoiding speech level choice, the forms which most clearly indicate speech level (e.g., those of List One and List Two in Sec. 2.1.1) tend to remain in Javanese, so that the speech level remains clear. Thus, the very forms which are Indonesian in Peranakan speech tend to remain Javanese in Pribumi speech, even at the lowest level. Thus, those forms occurring in Lists seven and Eight of Sec. 5.2.3, above, are most likely to remain Javanese in Pribumi speech, although they are the ones which are almost always put into Indonesian in Peranakan speech, if there is any Indonesian in the sentence at all. For example, in the following citation of a Pribumi speaker, the forms kuwi 'that', néng 'but', yhô (particle), ngantèq 'up to the point that' are left in Javanese to keep the $N$ level clear, where most of the rest of the sentence is composed of Indonesian loan words. Indonesian is underlined.

1. (Pribumi) Kuwi, wektu kuwi . . . néng maqaf yhô, nèq katakataku nanti, janganjangan ngantèq menyinggong perasaganmu, maqaf yhô. 'At that time. . . but I'm sorry if I say something that might, well, it might just hurt your feelings.

Were this a Peranakan sentence on the LMd level (i.e., a sentence with very few Indonesian loan words) the forms not underlined in citation 1 above would be the very ones to be put in Indonesian, not in Javanese. On the other hand, there are forms which tend to be in Javanese on even the highest level of Peranakan speech, which in Pribumi Indonesian would always be put in Indonesian, namely the markers and inflectional affixes. For example, in the following two citations we see the markers nya and yhang of Indonesian provenience in the Pribumi citation; whereas the Peranakan citation shows the markers -ée, sêng, and 1é, none of which would occur in constructions 
with Indonesian forms in Pribumi speech. Further, we see in the Pribumi citation Javanese choices for the form meaning 'there is' and the demonstratives to keep the leve1 (Krômô) clear, whereas in the Peranakan citation Indonesian is chosen for these forms. Square brackets indicate immediate constituents.

2. (Pribumi) Wônten maléh anu menikô, masalah [laré [yhang nilénya kurang begitu baéq]], ato [[anaq yhang dhatang] menikô bisa dhiterima.] /there-is also umm this problem child the-one-who his-grades insufficiently so-much good or child the-one-who comes that can-be-accepted/ 'Further, there is, umm, the problem of the child whose grades aren't good enough or whether the child can be accepted.'

3. (Peranakan) [Mamaé itu] [sudah rôndô], [dadiné ngerjaqnô japét]. [Itu [séng njladrèni]], [yha] [sudah diwarai]. [Ada séng mbôqmbôq] [kan] [sudah biasa], [Ê1], [wông [1ế bikén] [sudah sưi]], [yha.] her-mother that already widow so makes cakes. That the-one-who makes-dough, particle, already be-told there-are the-one-who oldwomen particle already experienced name because the-action-of make already long-time particle/ 'Her mother is a widow, so she has been making these cakes. The ones who make the batter already know how to do it themselves because they have been shown how. There are some old women who are experienced, El, because they have been doing it for a really long time.'

In Pribumi speech, when Indonesian is used in order to avoid problems caused by the speech levels and honorifics (Sec. 3.4ff.), many more of the forms which are in Indonesian are the same as those which tend to be in Indonesian in Peranakan speech--i.e., forms like the demonstratives and words for 'yes, no', etc., are likely to be Indonesian, just as such forms are in Indonesian in any Peranakan speech of the Md level or above. But, again in contrast with Peranakan speech, the markers are in Indonesian, not in Javanese (as is most frequently the case in Peranakan speech), and, further, the Pribumi speech with this function will also show shifts from Javanese to Indonesian which follow the phrase structure of the sentence. In the examples of Sec. 3.4ff. a clause is almost always entirely in Indonesian or in Javanese--i.e., there is rarely a switch from Indonesian to Javanese or vice versa within a clause, and almost never within phrase boundaries.

\subsubsection{Comparison of Peranakan with Pribuni Speech} from the Ethnographic Point of View

5.6.2.1 Difference in the Way that the Speech Level Systems Function

Peranakan speech differs from Pribumi speech in that it uses no honorifics, but in many other respects Peranakan and Pribumi speech levels function similarly. They both have a High-Medium-Low continuum: where the Pribumi height is determined basically by the number and character of $\mathrm{K}$ forms, the Peranakan height is determined basically by the number and character of forms of Indonesian provenience. Further, certain $\mathrm{K}$ forms occur only at the highest levels in Pribumi speech (Sec. 2.1.1) and certain Indonesian forms occur usually only at the highest levels in Peranakan speech (Sec. 5.2.4). Even here, however, there is an important formal difference between the 
Peranakan and Pribumi speech of any class of speaker. To wit, Peranakan speech only has tendencies for certain forms to occur at certain levels (5.2.4), and there are no restrictions of cooccurrence such as we find in Pribumi speech (Sec. 2.1). Further, there are Pribumi speakers who contro1 only Madyô and not Krômô, whereas all Peranakan speakers, as far as we have been able to find out, control all levels (although not all Peranakan speakers control standard Indonesian, a question separate from the speech levels). ${ }^{17}$ In the case of the Pribumi speakers who control Krômô as well as Madyô, there are further restrictions and lists of forms which are confined only to the M level (Sec. 2.1.3), whereas in Peranakan speech there are no special Md forms. And just as there seem to be no differences in control of speech levels among various Peranakan speakers, there seems to be nothing analogous to faulty $\mathrm{K}$ speech (attempts to speak at a level one does not control--Secs. 2.2.7 and 4.4.1) or Krômô Désô forms (analogically created K forms which are not accepted as correct--Sec. 2.2.5). There are indeed analogically created forms--Indonesianized Javanese forms (e.g., saqini 'now', etc., Sec. 5.1.4.2, the second rubric), but these forms are accepted as $H$ forms (although not recognized as correct Indonesian of the sort that is proper to use as the high language of diglossia).

Closely connected with the lack of restrictions of occurrence is the lack of consistency of speech level choice. ${ }^{18}$ Although there is a great deal of code switching in both communities, in the Pribumi materials we can find many examples of speakers who stick to the same speech level above the $\mathbf{N}$ level in direct address with a certain interlocutor over a long period of time (and, in fact, repeatedly). In fact, it is the exception for Pribumi speakers in direct address to use more than one level to a given speaker and, if it occurs, there is usually an explanation (Secs. 4.3, 4.4ff.). In our Peranakan materials, we have no good examples of speakers who consistently maintain a high level in direct address. For all of our recordings, speakers at the $\mathrm{H}$ level tend to move down to the $\mathrm{L}$ level at times.

\subsubsection{Differences in Factors Which Influence Speech Level Choice}

There are clearly differences in factors which influence speech level choice in the two communities. For the Pribumi, relative status is the primary factor (Sec. 2.2). Status is measured by absolute position: by birth into a family of priyayi class, by occupational status, by age. Intimacy is a secondary consideration. A vendor may address a child of higher class with Madyô. In any case we have innumerable examples of unequal relations, where a person of lower class speaks in a higher level than he receives (Sec. 2.1.2.1). There are no such examples in our Peranakan texts. In Peranakan speech the primary factors are the view which the speaker has of himself, the image which he wishes to project, and his view of the educational attainments of his interlocutor. Age and intimacy are secondary. We have no

17. We do not wish to imply that Peranakan do not have class differences reflected in speech. Educated speakers have clear tendency to speak on higher levels (with larger numbers of Indonesian forms).

18. It is impossible to make comparisons in this case, because our sample of Peranakan speech is much too limited. These remarks are subject to revision pending availability of more data. 
examples of unequal exchanges based on differences in class of the sort so frequent in Pribumi speech. The only unequal exchanges we have are in the cases involving an old speaker in conversation with an intimate a good deal younger than he is. The person who is old receives High and gives Low, but even in those cases, the old person may receive Low from some young speakers.

\subsection{What Language Do Peranakan Speak?}

As we have seen, Peranakan speech of Central Java may contain utterances which are unintelligible to a Pribumi Javanese who knows little Indonesian, but may well be intelligible to a speaker of Indonesian who knows no Javanese. Some utterances are also intelligible only to speakers of Javanese, while many are intelligible neither to non-Peranakan speakers of Indonesian nor Javanese (although Javanese with a knowledge of Indonesian can soon learn to understand almost any Peranakan speech).19

As we pointed out above (Sec. 5.1ff.) the grammatical structure of Peranakan speech is very close to Pribumi Javanese. Where Javanese and Indonesian rules differ, the Javanese rules are invariably followed. This point is illustrated most by the phonology (including morphophonemics and by the dropping of $\mathrm{di}$ and $\mathrm{ke}$ as discussed in Sec. 5.1.3.1). The rules over which the speaker has no conscious control are invariably Javanese, and for that reason alone, we may be justified in asserting definitively that Peranakan speech is a type of Javanese. ${ }^{20}$ However, there is an even stronger reason for considering this speech as Javanese. If we distinguish forms of inhibited, controlled speech from uninhibited uncontrolled speech, we find invariably that it is the Javanese variant which falls in the uninhibited, uncontrolled column and the Indonesian, in the inhibited, controlled column. What form does the Peranakan choose when he is tired, drunk, talking to himself, angry, fumbling for words, trying to establish a feeling of intimacy? And what forms does he use when he is in best control and most inhibited-talking to people with whom one must be careful (e.g., closing a business deal), or endeavoring to show himself as a person of status and standing? Invariably Javanese forms are included in the first group, and Indonesian in the second. This fact alone is enough to convince us that Peranakan are basically Javanese speakers on to whose speech Indonesian forms have been grafted in much the same way that bookish styles have been grafted onto the native English which we learn as children.

19. We have not tested these statements in any formal way. But they are based on our experience. We found that we could only have a Peranakan transcribe a recording made by a Peranakan. In many cases we found that Pribumi speakers had absolutely no notion of what a recorded conversation was about, whereas for a Peranakan, even one who had no knowledge of the people speaking, it was usually possible to transcribe accurately (if the recording was clear); and in any case the Peranakan were usually able to understand what the recording was about. There were some portions of conversations which were perfectly understandable to an Indonesian who knew no Javanese at all, but certainly these conversations could not have been understood by monolingual Pribumi.

20. One problem with using grammatical criteria is that Javanese and Indonesian themselves are very close in grammatical structure. However, it is also fair to say that, whenever Javanese and Indonesian differ, the Peranakan follow the Javanese way. 
In short, the Pribumi and Peranakan are both Javanese-speaking groups. They differ in the stylistic variants which comprise their repertoires. 


\section{CHAPTER 6}

\section{IMPLICATION OF THIS STUDY FOR SOCIOLINGUISTICS}

\subsection{Function and Its Effect on Form}

It is clear that the function of a code influences its formal features. Our best example is Indonesian as a code used by the Peranakan, and Indonesian as a code used by the Pribumi. These two codes differ strongly in their formal features (Sec. 5.6.1), and this difference is a consequence of the functions of each code. In Peranakan speech Indonesian is a speech level, and the choice of an Indonesian over a Javanese form is governed by factors of status of speaker, status of interlocutor, and intimacy between the speaker and interlocutor. This results in a thorough integration of the Javanese and Indonesian forms such that the switch from Indonesian to Javanese is independent of the phrase structure of the sentence. It also results in the choice of certain types of items for Indonesian and certain others for Javanese. For example, markers and inflectional affixes tend to be least affected by factors of level and are kept in the basic Javanese forms, even on the highest speech level where everything else is Indonesian. (They are forms of little importance in communicating the message--i.e., they are forms which no one need heed, and which the addressee usually tends to supply for himself, especially as they come out indistinctly in normal conversation.) In contrast, in the Pribumi community Indonesian functions as a code suitable for educated discourse, and as such the identity of the utterance as Indonesian is important. As a result, Indonesian is not integrated into Javanese speech, but rather the switch from Javanese to Indonesian and back again follows the phrase structure of the sentence. Further, the markers and inflectional endings, the very items which are ignored by the Peranakan, are, in Pribumi speech, invariably put into Indonesian, for they have an important role in identifying the utterance as Indonesian.

Another example of how function affects the form is the use of Indonesian in the Pribumi community. Here, Indonesian has a second function as a speech level of avoidance (Sec. 3.4), and in this fisction its formal features are different from the formal features of Indonesian when it is used in its function as the high form of diglossia (as an educated code). The character of the items for which Indonesian forms are chosen varies, depending on whether Indonesian functions as the educated code or as the speech level of avoidance. For example, when Indonesian is the educated code, the Pribumi make an effort to keep the level clear by inserting phrases which contain Javanese forms that prominently underline the speech level; whereas when Indonesian has its second function, that of avoiding speech level identification, it is precisely these forms that are made Indonesian at all costs.

In short, the purposes for which a code is used (as describable in terms of the settings, scenes, keys, subject matters, etc., which elicit the 
code) determine formal features of the code--which formal features accompany the switches to and from it, and also how the code affects the other codes which the speaker also has available (i.e., what types of admixture [borrowing] go on between it and other codes, at what level--phonological, morphological, syntactic, lexical, and at what frequency).

With this thought in mind we should reexamine the various codes which we find in Central Java from the typological point of view. We have suggested above that the function of Indonesian is similar to that of High speech in communities which show diglossia (Ferguson 1959). Although Ferguson does not describe the function of the High vis-à-vis the Low speech of his four communities in the kind of detail which we have discussed in Chapter 3 above (especially in the matter of how these codes function in everyday social intercourse), we have the impression and venture a guess that in these four communities the function of the High versus the Low codes has much in common with the function of Indonesian versus Javanese in Central Java.

Ferguson gives the following definition of diglossia (Ferguson 1959, Sec. 9):

DIGLOSSIA is a relatively stable language situation in which, in addition to the primary dialects of the language (which may include a standard or regional standards), there is a very divergent highly codified (often grammatically more complex) superposed variety, the vehicle of a large and respected body of written literature, either of an earlier period or in another speech community, which is learned largely by formal education and is used for most written and formal spoken purposes but is not used by any sector of the community for ordinary conversation.

The situation in Central Java does not conform to Ferguson's definition in one respect, that is, that Indonesian is not a variety of Javanese, but is, by any criterion or from any point of view, a different language. Also Javanese (the Low speech) has a long literary tradition and even a tradition of grammatical analysis (or at least of proper speech). This does not accord with the typical diglossic situation where, according to Ferguson, the pattern is for Low speech to have no status other than as a spoken language and, far from having any grammatical tradition, to be perceived by the speech community as grammar-less or somehow not a real language.

We suggest, however, that if we are to view diglossia as a sociolinguistic phenomenon, the definition of diglossia should be expanded to allow for situations such as we find in Central Java, where the Low and the High codes are different languages and both codes may indeed have a 1iterary and grammatical tradition, 1 for the pragmatics (the sociolinguistic meaning) of

1. Fishman (1972) expands the notion of diglossia to include all situations in any community which employs two codes for specific functions. Certainly the fact that the High and Low are the same language is of great importance in shaping the speaker's attitudes. In such cases the speaker may look upon the Low as being a corrupt version of High, and this attitude reflects itself in borrowings from High into Low and in other analogical reformations whereby $L$ forms are reshaped to look like High. But we believe it is irrelevant to the concept of diglossia whether or not this process is at work. In the first place, there must be many communities which have diglossia 
the Javanese and Indonesian codes are analogous to the pragmatics of the Low and High codes in the speech communities which Ferguson cites. Our argument runs as follows: from the outline which Ferguson presents, we can see great similarities between the functions of the Indonesian-Javanese codes on the one hand and the High-Low codes of Ferguson's communities on the other. We might hazard a guess that in all diglossic communities there is great similarity in the way the High and the Low codes operate--that is, the syntactic characteristics of the point at which code switches occur and the semantic and grammatical character of the forms chosen to be put into one code rather than the other. In other words, although all of Ferguson's speech communities differ in particulars and none are exactly like our Pribumi Javanese community, there are formal similarities in the way the codes operate in all of Ferguson's communities and in our Pribumi community. This is no more than a guess which we can make at this time, as we have not been able to examine data from other diglossic communities comparable to the sort which we have presented here.

In any case, the Indonesian-Javanese diglossia in Central Java is different in type from bilingualism of the sort where one language is giving way to another, or bilingualism of a more stable sort, such as in Quebec, where much of the French-speaking population knows English, but English has a very limited function. In Quebec French occupies not only the functions assigned to Low speech in diglossia but also many of the functions which are analogous to those assigned to the High code in Ferguson's diglossic communities or to Indonesian in Central Java. We will probably find that the formal features of English-French mixture are not comparable to the way Indonesian and Javanese are mixed. We will probably also find that the way English influences French in Quebec is quite different from the way Indonesian influences Javanese in Central Java. Of course, in all of this we are arguing from the premise that, if function affects form in the particular case we studied, function will also affect form in other cases. This hypothesis remains to be tested.

\subsection{Borrowing and Code Switching}

The concept of code switching--the switch from one code to another in an utterance--helps us to understand what intimate borrowing is and how it comes about. Intimate borrowing, which is a term we take from Bloomfield, is applied to a loan form of the everyday vocabulary, as opposed to a learned borrowing, which is a term or phrase which refers to some technological thing or cultural concept which has been newly introduced into the speech community.

where Low is not felt to be a corrupt version of High. (Our impression from our readings is that German Switzerland consists of such communities.) Further, we do not want to say a priori that all communities are diglossic in which the forms of daily speech are considered to be corruptions of a proper language and the proper language influences the daily language in the ways we have just described. For example, the Spanish creole spoken in Zamboanga, Philippines, is considered to be a corruption of good Spanish, and as such has been and continues to be strongly influenced by Spanish. Yet Spanish by no means can be said to function as the $H$ language of diglossia in Zamboanga (although in the past the Spanish probably regarded it as such, and thus the situation may have been very similar to the one which prevails in Haiti today). 
We postulate that intimate borrowing from one language or dialect (Xian) into a certain speech community which speaks language $Y$ does not occur unless Xian is a code, at least among some of the speakers, in the community which uses language $Y$. Thus, we can view intimate borrowing as nothing more than a case where a code shift has become a cliché and is no longer felt to be a code shift.

The motives and types of borrowing, thus, are as varied as are the motives and types of code shift. In the following citation, which refers to fixing a legal case, we see the form mudhah dhibèrèskan 'can be easily taken care of'. We may view this form either as a momentary code switch to Indonesian or a borrowing from Indonesian. The speaker is using Krômô, but since legal matters are normally in Indonesian (Sec. 3.2), this phrase would be peculiar if put in Javanese.

1. Menikô nembé saget. Mudhah dhibèrèskan. Saqèstu 1ho menikô. 'You can't do it until then. [But] it is easy to take care of it. Really. I mean that.'

We believe this phrase to be a borrowing because it has become a cliché, and the notion can only normally be expressed with this form. We call it a borrowing rather than a code shift, implying thereby that the use of this form does not have the sociolinguistic meaning of a shift to Indonesian--i.e., the nuances that would be associated with a shift to Indonesian are not part of the connotation of this form. ${ }^{2}$

The line between a code shift and a borrowing is difficult to draw. What for some speakers may still give the feeling of a code switch may fail to do so for others. Occasionally we get formal clues, in that the forms surrounding the Indonesian forms get put into Indonesian by attraction (Sec. 3.5.4). For example, native speakers react to the following citation as showing a shift to Indonesian, even though there is no really good Javanese equivalent for unsor 'elements'. A symptom of this reaction is that other forms which surround it are also Indonesianized. Indonesian forms are underlined:

2. Ha menikô, kulô meniô beberapa unsor niô kulô pelajari. 'Well, in this case I have studied (the problem) from several points of view.'

Other examples of code shifts to Indonesian which influence the forms around them are given in Sec. 3.5.4. The forms in that section also are on the borderline of being borrowings in Javanese, as they are often-heard phrases, but if our guess is correct that the attraction into Indonesian of adjacent forms (with the exception of the affixes--footnote 2) is an indication that the forms are still felt to be Indonesian, these sentences still exemplify code shifts and not borrowings.

Our view of borrowings, as a special kind of code shift that has become a cliché, allows us to view forms that have moved from one speech level to another as borrowings. For example, a form such as ra ndé dhét 'broke' is Ngoko and Krômô, although the forms out of which this phrase is composed, ra 'not', ndé 'have', dhêt 'money' are clearly Ngoko and have bôsô counterparts: mbôten, gadhah, and artô respectively. However, ra ndé dhét is used

2. However, the verb still has its Indonesian affixed (dhi-kan) as opposed to the Javanese affixes (in this case dipon-aken). Affixed forms are of ten borrowed into Javanese. (Cf. the examples in Sec. 6.2.1.) 
on all levels, and although originally it must have occurred in Krômô as a switch (of the sort described in Sec. 4.3), there is now no feeling of a switch. In fact, in Krômô it would sound like a hyper-form (an attempt to speak at a higher level than exists by speakers who feel obliged to impress their interlocutors with the fanciness of their speech). An example of this phrase is a sentence on the M level:

3. Pas ra ndé dhét nikô, 1ho, kulô. 'It just so happened that I was broke at that particular moment.'

Another example of a $\mathrm{N}$ form which has come into Krômô (underlined) :

4. Rèhné Bapaq menikô wông ora duwé, njêh tô. 'Since you are not a wealthy man, isn't that so?'

The $K$ analogue tiyang mbôten gadhah would be a hyper-form and sound prissy.

There are also examples of $\mathrm{K}$ forms which have been borrowed into the $\mathrm{N}$ vocabulary. For example geni 'fire' from Sanskrit originates in this way. A form which is at the border of being a borrowing or perhaps still a code shift is nrimah 'accept one's fate', exemplified in citation 1 of Sec. 4.3.2.

\subsubsection{Character of the Borrowing as a Reflection of the Character of the Code}

According to our view that intimate borrowing is a type of petrified code switch, we can classify borrowings formally in two ways: (1) according to the formal features of the code; and (2) according to the semantic features of the borrowing as a reflection of the function which the code shift had.

Borrowings from Indonesian to Javanese Pribumi speech are formally different from Indonesian borrowings into Javanese Peranakan speech. Pribumi borrowings do not consist of roots with Javanese affixes, but rather usually have the Indonesian affixes and often consist of whole phrases: e.g., keluarga berencana 'family planning' (where berencana consists of rencana 'plan' plus a verb-forming prefix ber-), pengalaman 'experience' (root alam), and many others. This is certainly a reflection of the fact that it is important for the Indonesian code to be identified as Indonesian. In Peranakan speech, on the other hand, where Indonesian functions as a speech level, the affixes are put into Javanese, for it is of no $\mathrm{m}^{-m e n t}$ that the sentence be identifiable as Indonesian. For example, the root liyaq 'look at' is frequently borrowed from High speech into Low or Low Medium. However, it is given Javanese, not Indonesian, affixes: ngliyaqi (Indonesian: melihat):

Dèqé ngliyaqi aku. 'He looked at me.'

Indonesian does, on occasion, also function as the high form of diglossia in Peranakan speech. When forms borrowed into Peranakan speech from the Indonesian have this function they will have the same formal characteristics as borrowings from Indonesian into Pribumi speech--i.e., they may well consist of phrases and bases to which Indonesian, and not Javanese, affixes have been added.

With reference to the semantic character of the forms, Indonesian's functions as an official and national language have led to the borrowing, into both Peranakan and Pribumi speech of numerous terms from the spheres in which the national language is used. The widespread use of certain entire Indone- 
sian phrases has led to the borrowing of common Indonesian words occurring in such borrowed phrases, e.g., selama 'while, during', lah 'predicate marker', kan 'so-and-so is the case, isn't it', and many others.

Further, Pribumi speech borrows Indonesian forms commonly employed to avoid the speech levels and honorifics, when Indonesian is used as a method of avoidance of speech level or honorific forms. Forms meaning 'say, give, put, tell, lend, take' usually require the choice of an honorific or a clearcut choice of a non-honorific, and Indonesian becomes the only way to remain neutral (Sec. 3.4.5). This has led to the adoption into Javanese of forms like kabari 'inform' to avoid KI paringi priksô or KA caôsi or aturi priksô or the hon-honorific nyeriyôsi. There are many other similar examples.

In Peranakan speech because of the role of Indonesian forms as a High speech level, we find borrowings of a great deal of intimate, day-by-day vocabulary, not found in Pribumi speech. These are forms which have moved downwards from High to Low and are of very much the same character as borrowings from Krômô into Ngoko (forms which have moved from Krômô to Ngoko) in the Pribumi speech. We list a few of these forms in Sec. 5.1.4, but in actual fact, the list of such borrowings is extensive--probably more than a hundred items. 
A male school teacher (S) aged 37 engages a stranger (P), a woman aged 70 , in a conversation. Both are passengers on a bus headed for Yogya, and the conversations takes place as they wait in the station In Munthilan. The conversation is almost entirely in Kromo.

1. S: Badhé tindaq pundi, Bu?

2. P: Ngayojô.

3. S: Ngayojô?

4. P: Penjenengan?

5. S: Inggéh Ngayojô.

6. P: 0 .

7. S: Sakéng tindaq pundi?

8. P: Tidhar Krajan.

9. S: 0 , Tidhar. Tuwi sedhèrèq?

10. P: Injéh. Mbaqyu kulô tilar donyô.

11. S: 0, injéh.

12. P: Sawek Setu.

13. S: Kôlô Setu?

14. P: Injéh. Menikô wau sampon, sampon wilujengan tigang ndintenan. Lajeng kulô wangso 1 .

15. S: 0 .

16. P: Tanggong jawap nggriyô.

17. S: Wonten Yojô wônten pundi?

18. P: Wônten Ndipôwinatan.

19. S: Ndipôwinatan. $0, \ldots$

20. P: Injéh, saq kidol Té Ha Er menikô.

21. S: Inggéh.

22. P: Penjenengan pundi, Naq?

23. S: Kulô wônten Jalan Kaliurang •

24. P: 0. Wônten Jalan Kaliurang.

25. S: Saq 1èr.

26. P: Pakem.

27. S: Mbulaqsumor.

28. P: Inggéh, lajeng Nggenthan?

29. S: Anu, Mbarèq naminipon.

30. P: Mbarèq.
1. Where are you going?

2. Yogya.

3. Yogya?

4. And you?

5. I'm going to Yogya, too.

6. Oh.

7. Where are you coming from?

8. Tidhar Krajan.

9. Oh, Tidhar. Were you visiting relatives?

10. Yes. My sister passed away.

11. Oh, yes.

12. Just on Saturday.

13. Last Saturday?

14. Yes. I went to the three-day ceremony. Now I'm going home.

15. Oh, yes.

16. I have to take care of things at home.

17. Where do you live in Yogya?

18. I'm on Dipowinatan Street.

19. Oh, Dipowinatan.

20. Yes, to the south of the T.H.R. (Amusement Area).

21. Oh, yes.

22. Where do you stay, son?

23. I live on Kallurang Street.

24. Oh, on Kaliurang.

25. To the north of...

26. Pakem?

27. Bulak Sumur.

28. Yes. In Genthan?

29. Umm, Barek. That's the name.

30. Barek.

31. Yes. To the north of Sendowo.

32. Yes. She wasn't sick before 
31. S: Inggéh, saq lèr Sendôwô.

32. P: Inggéh. Enggéh menikô, mbôten mawi sakét niô, lajeng tilar donyô, mbaqyu kulô menikô.

33. S: 0 , inggéh.

34. P: Mbaqyu kulô mbôten let.

35. S: Inggéh. Néng nggéh sampon yoswô menôpô?

36. P: Sampon pitong ndôsô kaléh.

37. S: 0 , inggéh.

38. P: Kulô pitong ndôsô, ông kaôtipon namong kaléh taon.

39. S: (Laughs softly.)

40. P: Nggéh teséh njarumi, nggéh saget (laughs). Kulô namong berah njarumi wônten peken.

41. S: 0 , njaét?

42. P: Njéh, berah gadhaanipon sedhèrèq .

43. S: Enggéh. Teséh mbôten ngagem sambetan, Bu?

44. P: Mbôten.

45. S: Wa, teséh ...

46. P: Inggéh kôq teséh kuwawi, Dèn.

47. S: Ha inggéh.

48. P: Berkahipon Engkang Kuwaôs.

49. S: Menikô mangké nggéh mbôqmenawi dumugi Té Ha Er.

50. P: Ha inggéh. Wông bésipon kadôs sôq seréng .... 0 , njéh wônten dhéng, yèn mbôten mlebet Té Ha Er menikô, raq Nggodhéyang.

51. S: 0 , inggéh.

52. P: Yèn Nggodhéyang mbôten mlebet wônten Té Ha Er.

53. S: 0 , enggéh.

54. P: Namong wônten wétan peken. Enggéh stangplat.

55. S: Menikô namong Baker kôq Bu, éngkang wônten ngrikô.

56. P: Inggéh. Asli kulô nggéh sakéng mrikô.

57. S: 0, mriki?

58. P: Nggéh. Wutah rah kulô nggéh mriki. Riyén Bapaq Simbôq bebôrô wônten Ngayojô, kulô teséh alét. Taon pitulas raq kulô nggéh séh alét. she died, my sister.

33. Oh, yes.

34. My sister, the one right next to me.

35. But she was old, wasn't she?

36. Seventy-two.

37. Oh, yes.

38. I'm seventy. We re only two years apart.

39. (Laughs softly.)

40. I still sew. I'm still able to work (laughs). I'm only a sewing machine operator in the market.

41. Oh you sew?

42. Yes. I work in a shop which a relative of mine owns.

43. Yes. You still don't need to use glasses?

44. No.

45. My! Still...

46. Yes, I'm still strong, sir.

47. We11, of course.

48. Thanks to the Almighty.

49. We'll probably pull into the T.H.R. [terminal in the amusement area].

50. Oh yes. But, you know, of ten times the bus doesn't...Oh, yes, of course, there are some that don't go to the T.H.R., but to Godeyan St.

51. Oh, yes.

52. If they go to Godeyan, they don't go into the T.H.R.

53. Oh, yes.

54. They only go to the east of the market. That's also a terminal.

55. It's only Baker that does that, Ma'am.

56. Yes. [changing subject] I'm originally from there, too [from Tidhar, the town she just finished visiting].

57. Oh, you're from here [from this area, rather than from Yogya, the place they are going to].

58. Yes. I am a native of this place, too. My father and mother moved to Yogya to try their luck when I was still 
59. S: 0 , ngaten.

60. P: Lajeng Bapaq Simbôq kondor mriki saq sedhèrèq kulô. Kulô sampon klajeng angsal sedhèrèq mrikô ....

61. S: 0 .

62. P: Awrat simah kaliyan tiyang sepoh.

63. S: Ha, inggéh (laughs).

64. P: Ha njéh ancasipon, yô wés mumpong, manggôno. Néng kulô menikô, antawés sedulor menikô sedinô rông ndinô, njéh?

65. S: Ha inggéh.

66. P: Suwé-suwé yô sôq bengkréq. (Both laugh.)

67. S: Inggéh. Menawi kempal ngaten -..

68. P: Enggéh, tô? Ha injéh milô ku1ô njéh krôsô, sithéq kandhan1 mawôn.

69. P: "Kôq durong réné?" Mbaqyu niô. "Taq sandhangi, taq pakani."

70. S: Kanton piyambaqan menôpô?

71. $P$ : 0 inggéh, kulô piyambaq. Rikô njéh piyambaq.

72. S: 0 .

73. P: Sampon mbôten sami gadhah simah menikô.

74. S: Putrô-putrô?

75. P: 0 , anaq kulô sampon ... njéh wônten, teng Yojô setunggal, éngkang setunggal wônten Plèrèt.

76. S: Plèrèt Yojô?

77. $P: N j e ́ h$, saq lèr peken. Engkang setunggal sampon gadhah anaq wôlu, éngkang setunggal rolas.

78. S: Wa (laughs).

79. P: Sampon kaléh dôsô laré kaléh.

80. S: Kaléh dôsô.

81. P: Nggéh.

82. S: Namong kaléh putranipon?

83. P: Tigô. Engkang alét plyambaq jaler, baqdô medal sakéng sekolah ... small. I was still small, you know, back in ' 15 .

59. Oh, I see.

60. Then Dad and Mom came back here with my brothers and sisters. Since I already had gotten married... [I stayed in Yogya].

61. Oh.

62. One's husband is more important than one's parents.

63. That's normal (laughs).

64. That's right. What I mean is, I thought as long as we are settled [in Yogya], we might as well stay there [and not go to Tidhar with my parents]. What I always say is, 1t's all right for a day or two to stay with relatives [but no longer than that], don't you think?

65. Sure.

66. After a while they are sure to quarrel. (Both laugh.)

67. Yes. When you live together...

68. Sure. That's why [I don't stay with my relatives]. I easily get hurt. They just have to say a couple of harsh words.

69. "Why haven't you moved in with me?" my sister keeps saying. "I'll give you clothes, I'll give you food."

70. Oh, you're all by yourself now?

71. Oh yes. I'm alone. She's alone, too.

72. Oh.

73. We're both widows now.

74. How abol:- your children?

75. Oh, my children are already...Well, there is one in Yogya. Another one is in Plered.

76. In Plered, Yogya?

77. Yes. Just north of the market. One of them has eight children and another one has twelve.

78. My (laughs)!

79. I've got twenty from two children.

80. Twenty.

81. Yes.

82. You only have two children? 
84. S: Medal sakéng pundi?

85. P: Sekolahipon rumiyén wônten Mbulaqsumor.

86. S: 0 , Gajah Môdô?

87. P: Njéh mbôqmenawi. Wông kulô menikô mbôten ngertôs. Kulô menikô tiyang butaurop, dadôs (laughs) namong répôt bap yôtrô: "Semanten, semanten, Mbôq," ngaten mawôn .

88. S: Néng dèrèng ngastô?

89. P: Dèrèng. Namong nyambi dadôs guru.

90. S: 0 , dhateng pundi?

91. P: Dhateng Kuncèn.

92. S: 0 , wônten Kuncèn.

93. P: Inggéh.

94. S: 0, wônten Es Em A Teladhan?

95. P: Mbôqmenawi, nggèné Wirôbrajan prôsekawanan menikô ngalèr.

96. S: Ha enjéh, ngalèr.
83. Three. The youngest, a boy, just finished school.

84. Where did he graduate?

85. He went to school in Bulak Sumur.

68. Oh, in Gajah Mada?

87. Yes, probably. I don't really know. I'm illiterate so (laughs) I only worry about the money. "I need so much, Mom, this much." That's all.

88. He doesn't work?

89. No. He only has a part-time teaching job.

90. Where?

91. In Kuncen.

92. Oh, in Kuncen.

93. Yes.

94. In the demonstration elementary school?

95. Maybe. To the north of the corner of Wirobrajan.

96. Oh yes. To the north of there. 


\section{Conversation 2. ENGAGING A DHALANG}

A party from the town of Wonosari goes to the house of a dalang (a performer of the shadow play) to ask him to perform at a wedding. The party consists $o \bar{I}(W)$, a man in his sixties, whose friend's daughter is getting married, his neighbor (P), who is a petty official in Wonosari and of the same age, but somewhat higher in status than $W$, a younger neighbor (M), and the son of (P), (S), who drove them to the dalang's house. By chance, a stranger (L), a man somewhere in his sixties, arrives at the dalang's house at the same time. P serves as the spokesman. They are greeted by the dalang's wife (B).

1. M: Kulô nuwon!

2. B: Nggô pinaraq riki.

3. M: Injéh.

4. B : Injéh.

5. L: Mônggô.

6. S: Nuwon.

7. L: Rakané wônten mbôten, tô? Rakané wônten mbôten, tô? Oo ...

8. B: Ponentôsi rumiyén, sampon wungu.

9. M: $0, n j$ éh.

10. L: Kôq tindaq, sakéng, sakéng pundi?

11. P: Enjéh, lha nganu ngat ...

12. L: 00 ..., Negari.

13. S: Enjéh.

14. P: Nô mentas nyambot damel?

15. L: Mbôten.

16. P: Nuwon.

17. D: Mônggô. Wah, sèwu!

18. P: Mônggô (laughs).

19. D: Laré-laré.

20. P: Enjéh (laughs).

21. D: Mbồ mônggô lenggahipon.

22. $P$ : Sampon, sampon nèh, Mas .

23. M: Enjéh sampon, riki mawôn.

24. B: Sampon, riki.

25. D: Ngaturi sugeng sedôyô mawôn.

26. all: Enjéh, pangèstu.

27. P: Saqkondoripon.

28. D: Injéh wilujeng. Pundi sedôyô lenggahé?

29. P: Kulô, Wônôsari.

30. D: 0 , Wônôsari.

31. P: Dôs njéh anu, énggal-énggalan ...

32. D: Injéh.
1. Hello!

2. Please come in.

3. Yes.

4. After you.

5. Please go ahead.

6. Excuse me!

7. Is your husband home? Is your husband in?

8. Could you wait a while? He has already gotten up.

9. Oh yes.

10. [after some time to P] Where did you come from, from...?

11. Well, we just came from umm the cit...

12. Oh, the city.

13. Yes.

14. Have you just come from work?

15. No.

16. (D comes out of the room) Excuse me!

17. Make yourself at home. Sorry [to keep you waiting].

18. No problem (laughs).

19. [Excuse all the] children!

20. Surely (laughs).

21. Why don't you move here [to the main table]? [Often there is a place clearly meant to receive visitors of high status and other places for lesser visitors. The visitors here have modestly taken a place reserved for lesser visitors.]

22. Oh, that is all right. You might... [get more important visitors] . 
33. P: Mator kémawôn. Dadôs sowan mriki kejawi badhé mangertôs dalemipon naq Pardi, ...

34. D: Do ... injéh, enjéh.

35. P: Kapéng kaléhipon gandhèng kulô menikô badhé gadhah kajat mekaten, ...

36. D: Injéh. kepareng utawi selô gongan supadôs dipongayengaken.

38. D: Oo, injéh (P laughs). Lajeng dintenipon menôpô, njéh?

39. P: Mbénjéng tanggal selangkong Agostos menikô.

40. D: Enjẻh.

41. P: Malem nemlikor.

42. D: Njéh. Kadôs teséh selô.

43. P: $00, a$, injéh. Njéh mator nuwon.

44. D: Njéh.

45. P: Estunipon menikô badhé, badhé sowan keng rôkô, njéh?

6. D: $0, n j e ́ h$.

47. P: Anu, mas Parman.

48. D: Parman, njéh.

49. P: Menikô anu, dadôs, e, pemeréntah setempat menikô teséh sôq nganu, rèhné rumiyén radi ...

50. D: Dhaérah pundi tô, menikô?

51. P: Wônôsarinipon, kithanipon.

52. D: Môngkô sampon kerep sanget.

53. P: Lha inggyéh. Néng sôq-sôq gandhèng kulô menikô $n j e ́ h$ sebagé pamông mekaten ...

54. D: Njéh.

55. P: Dôs, njéh sampon ngantos, mangké mindhaq ... wông rumiyén niô camat kulô éngkeng rumiyén niô jan diponkerasi.

56. D: 0, injéh.
23. Yes. This is fine right here.

24. We're fine, right here.

25. Welcome all of you. [Lit. I say to you that I wish the best for all of you.]

26. Yes. By your blessing.

27. The same to you.

28. Thank you. I am fine. Where do you live, all of you?

29. I'm from Wonosari.

30. Oh, Wonosari.

31. To make things, umm, quick...

32. Yes.

33. I'll just tell you exactly. I came here not only because I would like to know where you live and see your house, Mr. Pardi,...

34. Yes, yes.

35. But also, secondly, because [we are] going to hold a celebration.

36. Yes.

37. That is, if you allow me, or if you have time, I would like to ask for a wayang performance in order to make it a lively celebration.

38. Certainly (P laughs). What day is it going to be?

39. This coming August 25.

40. Yes.

41. The night before the twenty-sixth.

42. Yes. I think I still have time.

43. Oh yes. Thank you.

44. Yes.

45. Actually, I was going to see your elder brother [also a dalang. He did in fact ask the elder brother, but it turned out that the elder brother was not available.]

46. Oh, yes.

47. Mr. Parman.

48. Yes. Parman.

49. Umm, err, since the local government is still often... because before it was rather ... [Evident1y, it was necessary at that time to get 

57. P: Badhé rasol
rumiyén meniô, éngkeng njéh, mbôten kepareng. Mônggô, tô! Kulô njêh dadôs gedharang-dharang lampah kulô (laughs).

58. D: Nangéng mas Parman menikô njéh sampon kerep sanget dhateng .

59. P: Sampon, ha tiyang kôlô embèn wônten setanplat.

60. D: Injẻh.

61. P: Menikô, injéh; néng nggyéh menikô, mangké kulô menikô mindhaq dangu mbôten mangertôs. Ngaten lhô, Naq.

62. D: Enjéh.

63. P: Dôs njéh ku1ô jagi ngaten. Dôs èstunipon éngkeng badhé eee, gadhah kepentingan menikô, Paq Sosial Wônôsari.

64. D: 0 , injéh.

65. P: Dôs menikô kinten-kinten saget selô tô, menikô?

66. D: Selo, injéh.

67. P: Menawi dumugi, menikô dinten Setu Legi, malem Minggu Paéng.

68. D: Injéh. Anggèn kulô nyambot damel anu kôq, tanggalipon teséh enèm; setunggal, kaléh, tigô, dumugi wôlu menikô.

69. P: Enjéh.

70. D: Yèn éngkang pitulas mudhoq malah dèrèng.

71. P: Injéh (laughs). Lajeng njéh anu, Naq, èstunipon njéh senaôsô ator kulô wau nyuwon tulong ...

72. D: Injéh.

73. P: Namong kémawôn caranipon lajeng kadospundi menawi tindaq mrikô, ngaten.

74. D: Injéh.

75. P: Kadôspundi mangké ... (D laughs) caranipon?

76. D: Ngastô rèq, injéh?

77. P: Njéh, wônten. Dôs mangké menawi mandhap wônten setanplat $\ldots$.

78. D: Enjéh. permission from the local government to hold a wayang performance, and they had at times not allowed the performance to be held.]

50. What area is this?

51. Wonosari. In town.

52. But actually, they of ten held [performances].

53. Well yes, but with me as one of the town clerks, and so forth...

54. Yes.

55. So I wouldn't want things to get so far as to... Formerly our neighborhood head was given rude treatment.

56. Oh, yes.

57. There was going to be a rasul [anniversary of a death] celebration. They simply wouldn't allow it. What do you think of that? I went around like crazy, but to no avail (laughs).

58. But Parman often went there.

59. Sure, but that was at the [inauguration of the] bus station.

60. Yes.

61. This kind of thing, the older $I$ get the less I understand it. That's the way I feel, son.

62. Yes.

63. So, I just have to be careful. Actually, the one who is going to umm, have the celebration is the social welfare officer of Wonosari.

64. Oh, yes.

65. So, do you think you could be free then?

66. Yes. I am free.

67. So it will fall on the Saturday which is Legi or the night before Sunday which is Paeng. [ Legi and Paeng are names of days in the five day Javanese week.]

68. Yes. I am taken on the early days of the month: the first, 
79. P: Menikô lajeng Paq Sosial Wônôsari, Wônôsarinipon.

80. D: 0 , injéh, enjéh.

81. P: Antawésipon setunggal kilo. Wônten nggéh ... sekô ... teng ndalemé nikô sekéng setanplat, antawés ...

82. S: Eeng,... . wônten, wônten.

83. M: Wônten.

84. P: Sekilo, hé.

85. M: Pôqipon, balé ngalèr.

86. P: Ha, iyô, balé. Balé, klurahané dhéwé ngalôr.

87. M: Balé klurahan Wônôsari.

88. D: Engkeng ponkersaqaken kulô namong piyambaq, injéh?

89. P: Njéh, anu, kebiyasaqanipon mesthinipon ngagem pinten, kaléh, menôpô pinten?

90. D: Injéh, kaléh.

91. P: Lha injéh.

92. D: Ha injéh. Sampon. Mônggô haé.

93. P: Namong nggéh anu, nyuwon diponparingi ancer-ancer ngaten. Dadôs mangké mlèsètô, sampon ngantos kekathahen (laughs)!

94. D: Yèn kulô menikô, kulô dhasaraken, inggyéh, badhéyô kulô ngaken sampon saget, naéng njếh ... sedôyô menikô namong raq kanton jôdhôn.

95. P: 0 injéh, enggéh, injéh. Milô èstunipon njéh ngaten menikô, terkadhang mangké wônten mriki kulô takèn kilèn riku, "Wah, menikô Mas Pardi sampon saé." ( laughs.) Ha néng wônten ngrikô trangané engko, "Dhông-dhông," injéh, tô?

96. D: Ha injéh.

\author{
second, third, until the \\ eighth. \\ 69. Yes. \\ 70. The days from the seventeenth \\ onwards I haven't been booked \\ up. \\ 71. Yes (laughs). Also, umm, \\ this..., son. Actually, \\ although I have come to ask \\ for your help... \\ 72. Yes. \\ 73. Only, what would be the best \\ way to go about it, when you \\ go there, I mean. [I.e., how \\ about your fees?] \\ 74. Yes. \\ 75. How about it? (D laughs) The \\ procedure... \\ 76. Do you have matches? \\ 77. Yes. I do. So, you get off \\ at the station... \\ 78. Yes. \\ 79. You go straight to the \\ Wonosari social welfare \\ office, the Wonosari office. \\ 80. Oh, yes. Yes. \\ 81. It's around a kilometer. [To \\ S] Is it a kilometer to..., \\ from... to his house from the \\ station,... around... \\ 82. Yes, it is, 'tis. \\ 83. It is. \\ 84. A kilometer. \\ 85. In any case it is to the north \\ of the townhall. \\ 86. Uh-huh. Just to the north of \\ the townhall. \\ 87. The Wonosari townhal1. \\ 88. You just want me, right? \\ 89. Actually, usually you have to \\ take how many, two? Or how \\ many? \\ 90. Yes. Two. \\ 91. Oh yes, sure. \\ 92. A11 right. So it is settled. \\ 93. Only, I would like you to umm, \\ give us an estimate, so that \\ in case we make a mistake, we \\ won't err in giving you too \\ much (laughs). \\ 94. What I consider important is, \\ umm, even if I claim to be
}


97. P: Onô ra jodhoné menikô, njéh sampon, ndadôsaken. Terkadhang, "Wah, ha nèq niku, dèrèng maremaké." Terkadhang wônten mrikô mangké kedhôngan njéh sampon marem. Néng slir ... keng slirô sampon naté tindaq Wônôsari nô dèrèng?

98. P: Sampon kerep njian.

99. P: Lha menikô. Wônten Kèpèq mbôqmenawi, njéh?

100. D: Wônten ... injéh, wônten dhaérah éngkeng anu, wônten kithanipon sampon, Kranôn.

101. P: Lha, injéh. Kranôn.

102. D: Lajeng wônten Karang Tengah riyén sampon naté, njéh?

103. P: 0 , injéh.

104. D: Yèn wônten Ponjông, wônten Munggi, malah sampon kerep.

105. P: Injéh (D laughs). Njéh nyôbi mangké mugi-mugi lajeng saget wônten ka ...

106. D: Ha mṇiô, mbénjéng tanggal setunggal niô dhateng Tepos.

107. P: 0 , Tepos?

108. D: Njéh.

109. P: Setunggal mbénjéng-énjéng menikô? Dadôs setunggal Agostos?

110. D: Injéh.

111. P: Injéh.

112. D: Lajeng ...

113. P: Tep ... Tepos, klurahan menôpô ...

114. D: Injéh. Wônten klurahan.

115. P: Eeng, oo.

116. $D: N j e ́ h$ sedhèrèq èwet, ôq. Mbôten rasol.

117. P: 0 , inggyéh. Menawi kulô menikô rasolipon dhateng anu, paq Sugitô menikô. competent, but still it all really depends on whether we fit together [i.e., I might not really be the right one].

95. Oh yes, oh yes. That is why it is like that. Maybe some time in the future I will ask my neighbor in the west, and he' 11 tell me that you are one of the good ones. (D laughs.) But in another place all they say is, "Well, actually...., actually..." You know what I mean?

96. Well, of course.

97. Whether or not we fit, never mind [we can't know in advance]. We have to come to an agreement. Sometimes it comes out, "Tch-tch, that wasn't very satisfactory." At another time in another place, they will be completely satisified. But anyway, have you ever gone to Wonosari?

98. Oh, yes. Several times.

99. Oh, yes. You probably were in Kepek, weren't you?

100. Oh, yes. I was in the area that is, umm, within the town limits, Kranon.

101. Oh, yes. Kranon.

102. And I was also once in Karang Tengah.

103. Oh, yes.

104. I have been in Pondjong and Munggi, several times in fact.

105. Yes (D laughs). Well, I hope that $y$ su will also turn out to hit it off in [the city].

106. On the first I am going to Tepos.

107. Oh, Tepos.

108. Yes.

109. On the first coming up? So, on the first of August.

110. Yes.

111. Oh, yes.

112. Further...

113. In Tepos? Will it be at the village head's?

114. Yes. At the village head's. 
118. D: 0 , injéh .

119. P: Néng kanton mbénjéng tanggal selangkong menikô (laughs). Selangkong Juli.

120. D: Injéh. Ha njéh sampon. Mônggô ngaten mawôn: prayôginipon, ngaten, sakéng ndalem mbôten ...

121. P: Mbôten, mbôten, nggyéh, mbôten.

122. D: Mangké ngaten kémawôn: yèn sekinten mangké kulô ... kulô dom, lan kados kôq njéh dèrèng cekap, mangké nggyéh, kulô mator kirang, 1hô. Naminipon raq sekécô (laughs).

123. P: Mbôten anu, njéh, mbôten perlu pekèwet. Kantôn kulô aturi maringi ancer-ancer semanten, ngaten. Dadôs mbôten anu, mbôten pekèwet. Dadôs kagem penjenengan, nggéh sampon pekèwet. Estu.

124. D: Injéh.

125. P: Ong njéh, sedôyô menikô pon ... ponréncangi nyambot dame1 saqèstu, ngaten (laughs). laughs) Ha injéh. Lajeng paminipon tindaq Tepos menikô, lajeng ngaten kémawôn.

126. D: Injéh. Wônten Tepos menikô, nggyéh nuwon sèwu...

127. P: Inggyéh.

128. D: Kulô nyuwon gangsalwelas.

129. P: Inggyéh. Ha lajeng menawi kagem Wônôsari, pinten? Mônggô!

130. D: Ha njéh, sampon, mônggô (M laughs ).

131. P: Upami tigôwelas, sampon ... sampon dumugi menôpô dèrèng? Menawi wônten Wônôsari?

132. D: (laughs) Injéh ...

133. P: Kinten-kinten mônggô diponpenggaléh.

134. D: (laughs) Injéh.
115. A-ha.

116. They are only going to have a wedding. Not a rasul [anniversary of death].

117. Oh yes. When I have a rasul, I have Mr. Sugito.

118. Oh, yes.

119. But we still have to take care of the twenty-fifth. The twenty-fifth of July.

120. Oh yes. But let's just do like this: the best thing would be if after I leave your house, if it is not...

121. Oh, no, if you don' $t$ mind...

122. Let's just say that after I, umm, divide it up and it seems like there isn't enough, I'll just say it is not enough. To make it more convenient. -..

123. There is no need to be hesitant [at setting a price]. So, all there is for me to do is give it to you if you give me an estimate of around how much it is going to be. You shouldn't be hesitant. Really, you yourself should not feel hesitant... I mean that.

124. Yes.

125. [You don't need to feel hesitant to name a price] because we 've all been helped by your work. Really, that's the way I feel about it (laughs). (D laughs.) Yes, of course. How did you do it in Tepos? We can do it the same way.

126. Well, yes, in Tepos, umm, you won't mind?

127. No.

128. I asked for fifteen.

129. Oh yes. Now for Wonosari, how much? Please tell us.

130. Well, umm, it is up to you. (M laughs.)

131. Supposing we say thirteen, would that be close, or not? That's for Wonosari. 
135. P: Séng taq jikoq, wés cukop hurong, hee ... Dôs menikô mangké, 1hô. Yèn tindaq Tepos mniô ponpethoq menôpô mbôten?

136. D: Wônten setanplat, injéh dalu.

137. P: 0, ponpethoq.

138. D: Injéh.

139. P: Em, yèn ngaten, artôsipon, sami kaliyan ... Yôs, saqiki, saqniki ngaten mawôn: upami njor menikô étanganipon poncaôsi kawanwelas ngaten mawôn.

140. D: Injéh.

141. P: Dhiséq, dhiséq ké sèwu, nggéh?

142. S: Inggyéh.

143. P: Dôspundi, Paq?

144. D: Ha injéh, sampon (laughs).

145. P: Ha menikô menawi sampon ngaten, lajeng mônggô kulô aturi nyaôsi ... tali.

146. D: Dipontanggali?

147. P: Njéh. Jéng mbénjéng pami saqmniô penjenan ... ha mniô mbénjéng kanton ...

148. D: Tigôwelas.

149. P: Njéh.

150. D: Dhawah Agostos menôpô Juli, njéh, Paq?

151. P+S: Agostos.

152. P: Menikô wônten tanggal selangkong.

153. S: Selangkong malem nemlikor.

154. P: Minggu mniô, malem Minggu, njéh?

155. P: Injêh, malem Minggu Paéng.

156. D: Nyon sèwu kulô aturi nyerat.

157. P: Nyeratipon dôspundi? Wônôsari ngaten?

158. D: Injéh. Selangkongipon menikô.

159. P: Injéh. Wônôsari, njéh?

160. D: Injéh. Njéh, sampon.

161. P: Nha, menikô saqsamponipon ngaten, kulô ngatoraken panuwon.

162. D: Enjéh.

163. P: Lan menikô pinôngkô kagem tangsol, mekaten.
132. We11...

133. Approximately how much, think it over.

134. (laughs) Yes.

135. [to himself] I wonder if I brought enough along... hmm... Let's say like this: when you go to Tepos, do they fetch you [at the station] or not?

136. Well, it's usually night when I get to the station.

137. Oh, they pick you up.

138. Yes.

139. Hmm, in that case that means... the same as... [to himself] $0 \mathrm{~K}$, I have 1t. We' 11 say it's like this: suppose we just figure on giving you fourteen.

140. Yes.

141. [To S] Give a thousand in advance, right?

142. Yes.

143. How about 1t?

144. All right. Fine (laughs).

145. If that is all right, would you allow me to give you a... down payment?

146. What date did you want?

147. Yes. So, when you... so next time all that there is left is...

148. Thirteen.

149. Yes.

150. It is going to be in August or July?

151. August.

152. This will be on the twenty-fifth.

153. The twenty-fifth, the night before the twenty-sixth.

154. That's Sunday, isn't it? Saturday night.

155. Yes, the Saturday night that falls on Paeng.

156. Excuse me. Please write it down.

157. How shall I write it? Wonosari?

158. Yes. On the twenty-fifth?

159. I write Wonosari, right?

160. Yes. Yes. Fine. 
164. D: Njéh, sembah nuwon.

165. P: Mbénjéng kanton nyaôsi tigôwelas, ngaten.

166. D: Njéh.

167. P: Injéh, tô Naq?

168. $D: N j e ́ h$ ( $P$ laughs).

169. M: Lha menawi menikô genah sampon terang nyimpol mniô, mbôqmenawi Paq Sosial badhé mundhot présô, saqmentkô saé lan raménipon kadospundi? Menôpô ponsumanggaqaken, mbôten perlu mbénjéngmbénjéng menikô, mekaten. Menikô ponmusowarahaken, sekécô.

170. P: Aaa, nôpô kagungan panyuwon, nôpô kadospundi?

171. S: Mbôten, mbôten. Njéh mangké ponmusowarahaken rumiyén.

172. P: Njéh, njéh.

173. P: Njéh.

174. S: Bab mangké namong kulô serahaken supadôs ramé, nggyéh tô?

175. P: Enggéh, neq côrô kulô, njéh.

176. S: $\mathrm{Bab}$ keperluan menikô, namong enjéh menikô, badhé ...

177. P: Mantu.

178. D: 0o, njéh.

179. S: Mantu ( $P$ laughs). Ningkahaken anaq kulô menikô.

180. P: Ha mangké diponsumanggaq-aken.

181. D: Injéh.

182. P: Tor éwô semanten mbénjéng kanton-kanton Mas Dhalang rawoh, wah ... wônten perébahan, nyuwon menikô. Lha, injéh sampon, kanton manot.
161. Now, after this, I would like to express my thanks.

162. Yes.

163. And this is for the advance.

164. Yes. Thank you very much.

165. That leaves thirteen for next time, right?

166. Yes.

167. Right, son?

168. Right. (P laughs.)

169. Well, if we have come to a clear conclusion, maybe the Social Secretary is going to ask what sort of theme and action is being planned. Or shall we just leave it up to you? We don't have to put it off. Probably the easiest thing would be if we discussed it right now.

170. Oh, do you have any preferences, or what?

171. Oh no, no. Well perhaps we should discuss it first.

172. Yes, yes.

173. Yes.

174. As far as how it should be, I leave it to you to make it lively, right?

175. Yes, that's what I would do.

176. What is being held for... It is only going to be a ...

177. Wedding.

178. Oh, yes.

179. A wedding. (P laughs.) I am marrying off my daughter. [Actually it is not his own daughter.]

180. In any case, I leave it up to you.

181. Yes.

182. In any case, when you get there, if there are some last minute changes, I would ask you just to do as they say.

183. Of course, as long as $I$ am $a b l e$, or it isn't a story not normally performed in the shadow play. (All laugh.) You know it is like the Dahono group that is supposed to play Kethoprak. They never play 
183. D: Lha injéh, watôn saget. Utawi sanès lampahan cucal kulô (everybody laughs). Ha menikô margi raq wônten tô, aa, Dahônô menikô, wông kethopraq kôq ra tau lakôn kethopraq. Ha menikô raq njéh ... (everybody laughs).

184. P: 0 , injéh. Ha mônggô rèhnéng sampon cekap, môngkô njéh tebéh, mbôqmenawi cekap semanten.

185. D: Wèh, mbôq mangké rumiyén .... (D laughs and $P$ laughs).

186. S: Nggéh teséh werni-wern1 betahipon.

187. D: Injéh (laughs).

188. P: Kulô kinten cekap ngaten kémawôn. Sampon ngantos wônten menôpô-menôpô.

189. D: Injéh.

190. P: (laughs) Pareng, Naq.

191. D: Mônggô ... mônggô.
Kethoprak. We11 now if for this performance... (Everybody laughs.)

184. Yes. All right. Since I think we have accomplished enough, since it is quite a distance, maybe we should call it a halt now.

185. Oh, why are you rushing... (laughs and $\mathrm{P}$ laughs).

186. Yes. We still have lots of errands to take care of.

187. Yes (laughs).

188. I think it is enough for now. We don't want to have problems.

189. Yes .

190. (Laughs) Bye.

191. Bye. 


\section{Conversation $3 . \quad$ SELLING LAND}

A college student $(K)$ discusses with his landlord (M), a middle-aged villager, matters concerning a piece of land which he is buying from $M$. The recording was made by another student (A), who comes from the same village as $K$. The scene is $K^{\prime} s$ house on a Saturday afternoon as $K$ is preparing to go home for the week-end. A drops in to send a message home through $K$. A and $K$ exchange Ngoko. They speak Kromo and Kromo Inggil to $M$ and receive Madyo and occasionally Kromo with Kromo Inggil, depending on $M^{\prime} s$ feelings at the moment.

1. A: Kulô nuwon!

2. K: Ayo, Lép! Arep mùléh?

3. A: Kulô nuwon, Paq!

4. K: Arep muléh?

5. A: Ora!

6. K: Arep ngôpô (laughing)?

7. A: (to $M$ ) Nepangaken rumiyén (laughs). Alép. Kulô panggènanipon paq $\ldots$ paq Ranu. Heh.

8. M: Enggéh paq Ranu mriki?

9. A: Enjéh.

10. M: Martôsukarjô.

11. K: Tônggô (M laughs)!

12. A: (to $K$ ) Lha Daryônô endi?

13. K: Engko raqan.

14. A: Engko?

15. K: Weléng pô titép?

16. A: Aku ki ra isô muléh.

17. K: He-eh!

18. A: Engko nèq ketemu Bardi whaé kôndhô ngono kuwi. Aku ra işô muléh, "Mengko kudu mréksaqké dhôkter," ngono whaé.

19. K: Arep ônô ôpô? Kôndhô pô, kangsèn ro Bardi pô piyé?

20. A: Jôgô pit!

21. K: 00 !

22. A: Nèq kepethoq nông nggréjô engko nèq kônô grenengan, "Wa, Alép anu é, bajigor!" ngono raq cilôkô aku.
1. Hello. Anybody home?

2. Hi, Lip! Come in! Are you going home?

3. (to the landlord) May I come in, sir?

4. You going home?

5. Nope.

6. What are you going to do (laughs)?

7. (to $M$ ) May $I$ introduce myself? I am Alip. I stay in Mr. Ranu's house. Hmm.

8. You mean my neighbor here, Mr . Ranu?

9.. Uh-huh .

10. I am Martosukarjo.

11. Your neighbor (M laughs).

12. (to K) Where's Daryono?

13. He was going later, wasn 't he?

14. Oh later?

15. Do you have anything you want me to do or bring?

16. (Tell them) that I can't go home.

17. OK.

18. When you see Bardi tell him just that. I can't go home. Tell him I have to go see the doctor.

19. Why, what gives? Did you tell Bardi something or agree to meet him or something?

20. (I was supposed to be in charge of) guarding the bicycles.

21. Oh!

22. When you see him in church he is probably going to grumble, "Alip is terrible!" If he 
23. K: (laughs) Hiyhô.

24. A: Menawi mriki séng manggèn ...?

25. M: Kathah.

26. A: Kathah (M laughs).

27. K: Jané mèh mangkat aku mau nèq nggoh ra digéndhôli. Iki aku wés nggô kunci kamaré. Wés tekan ndalan teros dindhek bapaqé (laughs).

28. A: (to M) Sawek rembakan penténg nôpô?

29. M: Mbôten, pôkôqé méng ku1ô kèn nggolèqké butoh (laughs), cukop.

30. K: Lajeng ngéngingi ndhaftaraken meniko, mbôten nganggé artô, tô, Paq?

31. M: Mèng seksi mentkô, seksi ... seksi pembayaran, angger...

32. K: Ha menikô éngkang ...

33. M: Nggéh kedah dikèqi seksi ngèten. Mengké pôkôqé pasrah lé nggolèq nggôn dhaftaran niku, raq awaqé dhéwé amréh kepénaq, mbôten sah lungô-lungô. Kulô pasrahké paq Dhukoh bèn ndhaftarké nggôn.

34. K: Ha nggéh raq tunggal énjéng tô, Paq?

35. M: Non?

36. K: Menikô raq dadôs setunggal mbénjéng, tô?

37. M: Lha nggéh, néng sarèhné riku nggéh nganu $k i$, mèn nggo tuku-tuku udot kanggo seksi niku, ngaten niku, raq meksô nganggé.

38. K: Lha sarat ...

39. $M$ : ... saksèn, mboh saq endhél ngèten.

40. K: Pinten?

41. M: E?

42. K: Pinten? talks like that, that's no good for me, you know.

23. (laughs) of course!

24. (to $M$ ) Who all stays here?

25. Lots of people.

26. Oh yeah, lots.

27. Actually I was about to go except I was stopped on the way out. I already (had the room locked up) and was carrying the key. When I got outside, I ran into my landlord (laughs).

28. (to $M$ ) Are you having an important discussion?

29. No. Actually all I need to do is get some money to take care of the arrangements (laughs). That's all.

30. Now as for the registration, that doesn't cost anything, does it?

31. Only for the witnesses, the notarization of payment, as long as...

32. Well, that is what...

33. You have to give something to the witnesses. The main thing is that we will leave it up (to them) to take care of the registration business, so we don't have to fuss with it ourselves. We won't have to go around. I'11 leave it up to the Dhukuh [neighborhood leader] to register the place.

34. It can be done all at one time, can't it?

35. Pardon:

36. This (money that I have to pay) can all be turned over with my other payments, can't it?

37. Oh, sure, but since they are also going to umm...., you just need a little to buy cigaretts for the witnesses, you know what I mean? You know you got to have that.

38. We11, exactly what...

39. Oh, just for the witnessing, a few pennies or so. 
43. M: Pon saq-saqé mangké, riki kôn nggôwô ...

44. K: Mangké côbi kulô nyuwon pérsô Bapaq rumiyén bap ngéngingi menikô, sangu-sangu menikô, dèrèng saget nganu ...

45. M: Pôkôqnèn nggéh anu, awaqé dhéwé ki amréh kepénaqé lé ndhaftarké, ra sah lungô-lungô. Dhasaré heng présô tô, kaléh kuliyah niku nè̀q $\ldots$

46. K: Enjéh.

47. M: Môngkô nèq és dinô Minggu, ngrikô nggéh prèi. Nggéh menikô supayané niku ndhaftarké niku awaqé dhéwé amréh kepénaqé teng omah mawôn. Néng yhô carané ki yho nggo bécaqan mèn ndhaftarké, ngôten niku. Nggéh nggé paq Dhukoh ngôten, raq awaqé dhéwé raq pénaq.

48. K: Ha enggéh.

49. M: Tegesé pénaq $k i$ awaqé dhéwé méng mikér lé koliyah, méng karèq nyadhông kapan dhawué paq Dhukoh lé ngidol mriki.

50. K: Anu, nyaôsi sangu menikô pinten èwu nôpô pinten atos?

51. M: Pinten ...

52. K: Nyaôsi sangu menikô. Kulô nggéh mbôten wanton-wanton menawi ...

53. M: Anu ...

54. K: Teng nggèné paq Dhukoh nôpô nggèn seksi niku kulô dèrèng $\ldots .$. Wông menikô sipatipon sawek sementara, tô, Paq.

55. M: Enggéh.

56. K: Milané kulô dèrèng wanton-wanton ngecolaken artanipon.

57. M: Nggéh gangsalatos nôpô pinten? Menawi gangsalatos yhô niku taséh sekedhéq.

58. K: Ha enjéh menikô...
40. How much?

41. Huh?

42. How much?

43. Just any amount. So I can bring...

44. Let me ask my father about this, umm, this money matter, because I can't...

45. The main thing is that we will have an easy time in registering. We won't have to run around. Since you know yourself you have classes and all...

46. Yes.

47. But if you do it on Sunday, you will be off. That is to say, when we register it, so that we' 11 have it easy, we' 11 do it at his house. Just a bit for the area head, so we don't have a hard time. [I.e., the area head will go to the city hall to register the transactions and bring the papers back to his house for them to sign on Sunday.]

48. Of course.

49. What I mean is it will be easier for you if all you have to do is think about your studies. All we have to do is wait for the area head to call us to go south [go downtown for the final transfer].

50. How much pocket-money am I to give--how many thousand or how many hundred?

51. How many...?

52. How much am I to give? I don " $t$ dare just... (give it if it is a considerable sum).

53. Umm.

54. To give to the area head or to the witnesses, I don't... Because anyway this is not the final transaction, is it?

55. No, it's not.

56. That way I am not in a position to make any disbursements.

57. Yes. Five hundred or so. 
59. M: Enjéng ngôten, ra wurong yhô ... anu ...

60. K: Enjéh.

61. M: Sésoq raq yhô ènèng anu 0 , ha wông ...

62. K: Sinaôsô gangsalàtos menikô mnô môngkô yèn panjenengan badhé nyaôsi piyambaq dôs pundi, enjéh tô?

63. M: Enjéh.

64. K: Mộnggô yèn penjenengan ngersaqaken menikô nggéh mônggô. Mangké artô éngkang ku1ô caôsaken penjenengan kulô caôsaken teng ...

65. M: Mbôten kétang njéng étungané ...

66. K: Enggéh, kôq. Saqmenikô mergi umom ...

67. M: Kaléh mah thithéq nggéh awaqé dhéwé mah isô ...

68. K: Nggéh menikô kulô nganué njenengan.

69. M: Enjéh, pôkôqé njenengan ...

70. K: Menawi ...

71. M: ... pasrah kulô ngèten mawôn, njéh?

72. K: Nangéng ngéngingi ...

73. M: Ngéngingi anu niku timbangané malahan, méng kulô kaléh paq Dhukoh mon njaloq ...

74. A: Tinimbang mas Kartônô ndadaq ...

75. M: Enggéh, wông ...

76. A: ... mlampah.

77. M: Mlampah.

78. K: Mbôten. Nggéh ngéngingi étungan nôpô menikô, mangké yèn kathah-kathah, kulô nggéh mbôten gadhah artô mesthinipon, Paq.

79. M: Enjéh.

80. K: Môngkô lèh $n j$ enengan menèhi dhuwét okèh-okèh, wông aku dhéwé yhô ra ndé dhuwét, kôq (A laughs).
Five hundred would probably not be enough.

58. Well, that's just the problem...

59. It is inevitable that we are going to have to... umm...

60. Yes.

61. There is surely going to be umm, because after all...

62. Even five-hundred ( $I$ am not prepared to give now). But if you would like to make the payment yourself,... How about it? Don't you think that would be the best?

63. Yes .

64. If that is what you want to do, that would be all right with me. The money I give you I will give to...

65. That isn't included in our final reckoning.

66. Yes it is. I think it would be better to do things the normal way.

67. But with just a small amount we can in fact...

68. Well, $I^{\prime} 11$ just leave it up to you!

69. Yes. The main thing is you...

70. If...

71. You leave it up to me, that would be fine.

72. But as for the...

73. As far as that is concerned, rather than (you do it), I'll work it out with the area head myself...

74. Rather than Kartono be bothered to...

75. Yes. Because...

76. ...go over there.

77. Go over there.

78. That's not what I mean. I'm talking about the costs. If it comes out to be a great deal, I am surely not going to have the money for that.

79. Yes.

80. Since you plan to give a fair amount of money,... Because I myself don't have the money (A 
81. K: Môngkô yèn penjenengan ajeng maringi, yhô kuwi, menikô sakéng manah penjenengan piyambaq menikô. Mbôten, sanès sakéng kulô menikô. Ngéngingi éngkang resmi-resmian menikô mbénjéng yèn... Menikô éngkang secôrô padhang-padhangan.

82. M: Enjéh. Enggéh niku nggéh padhang tô, niku! Wông lumrahé wông anu $e$... (laughs). Supôyô awaqé ki tho mangké ôjô nganti menyinggong lé kuliah.

83. K: 0 , ngèten. Néng sampéyan pérsô...

84. M: Enggéh, turé niku nggéh ra wurong nggéh détong, é. Nggéh ragat, tô?

85. $\mathrm{K}$ : Ha néng nambahi kathah ragatipon.

86. M: Nggéh mbôten tô, ha mangké éntoq nyudô niku. Nyudô mbôten perlu kaléh jumlahé anu, niku raq mbôten bédô tô, niku nggian.

87. K: Séng pôkôq niku nggéh ...

88. M: Padhané rôngatos, nggéh tô, mangké repôtké satos. Raq pon sudô pinten, upaminipon.

89. K: Inggéh.

90. M: Pinôngkô sudané niku raq méng kanggé niku, niku raq kulô, tô? Naminé raq mbôten sudô, malah éntoq bathi nèq diétong (laughs).

91. K: Enggéh. Mangké.

92. M: Enggéh, tô?

93. K: 0 , nôpô mangké pon rembak dinten Senèn whaé? Njenengan niku butoh saqsedhengé tô, Paq?

94. M: Enggéh . laughs).

81. If you plan to give them some money, that is... it's from the goodness of your heart. It's not, not from me. As far as the official fees go, when... Excuse me if $I$ be frank about all this.

82. Yes. What I said is perfectly frank, too! It is the usual way to... umm, so that you yourself won't... it shouldn't have to disturb your studies.

83. Oh, yes! But you know...

84. Yes. And further, that has to be part of the reckoning, it is part of the expenses, too.

85. But it does add a lot to the costs!

86. Oh, no! Because you' 11 be able to get it cheaper in the long run. It's cheaper because you don't have to (fuss) about the amount. That all amounts to the same thing, doesn't it?

87. The main thing is that...

88. For example if it is two hundred, we' 11 just report a hundred, you know what I mean? That way we have already gotten the fees down by so-and-so much, for example.

89. Yes!

90. When we lay out money to lower the costs, it is only for that, the way I look at it. It is not really an outlay, but rather you make a profit, if you calculate it.

91. Yes. When...

92. Isn't that so?

93. How about if we discuss it on Monday? You probably are going to need the cash to handle the problem, aren't you?

94. Yes.

95. Actually, I plan to bring it on Monday. As for the time that we go to see the Head, we can't say for sure. We really 
95. K: Kulô ki jané kulô nggéh mbetô, nggéh soq Senèn. Lajeng ngénging 1 wekdalipon sowan paq Dhukoh menikô dèrèng temtu, dèrèng temtu jam-jamipon. Mentkô mangké -..

96. M: Enggéh.

97. K: Kulô rembak menawi kulô sampon dhateng mriki.

98. M: Enggéh .

99. K: Dadôs mnikô gampél, mnikô ngéngingi wekdal. Ngéngingi saksi, kaléh njenengan, kulô serahaken njenengan.

100. M: Enjéh.

101. K: Nggéh penjenengan nggé putusan énggal menikô artô sepalian, tô Paq?

102. M: Enggéh.

103. K: Wôntenipon niku, lajeng bentoqipon ... Pancèn kulô -....

104. M: Bentoqipon mangké yèn pon absah, tandhatangan.

105. K: Enjéh.

106. M: Menikô saratipon (laughs). Déné sah kelurahan, "Wah Paq, njéh mekso teséh kırang sekedhéq," kulô tampi kôq nggian.

107. K: Enggéh (laughs).

108. M: Ha néng nyatané, yhô, nggo golèq butoh $k i$, yhô angèl.

109. K: Enjéh.

110. M: Néng nèq dicaqké ora mbejaji (A laughs). Lha enggéh, mbôten?

111. K: Enggéh. Lajeng wiyar ...

112. M: Môngkô lé nggolèq ki jané yhô angèl. can't set the time yet. Later when...

96. Yes.

97. I'11 discuss it after I get back.

98. Yes.

99. Anyway, the matter of the time is no problem. As far as the witnesses are concerned, you handle it. I will leave that to you.

100. Yes.

101. Do you agree that for this new arrangement we split the costs?

102. Yes.

103. So that's the way we' 11 do $1 t$. Now for the format... Actually, I...

104. The way it is going to be is that after it has been certified, we sign.

105. Yes.

106. Those are the requirements (laughs). But when we certify it at the village head's [the next step up] we might run into something like: "I am afraid that it isn't going to be quite enough money." Don' $t$ worry, we' 11 do it the same way [i.e., we split the costs].

107. Yes (A laughs).

108. It turns out it is not easy to get hold of money this way [by selling land].

109. Yes.

110. When you try to do it, you don't get enough to make it worthwhile. (A laughs.) Right?

111. Yes. Now for the width...

112. On the other hand, it's no joke to try to earn money these days. 


\section{Conversation 4. DISCUSSING A NAUGHTY CHILD}

Probo, the son of an impoverished school teacher in a small town just to the north of Yogya, has been sent to live with a school teacher (S) and his wife $(P)$, so that he may continue his schooling and help in the household. He did not work out and was finally sent home. The next day $S$ and $P$ sent for Probo's mother (M) to explain why it was that they had to send Probo home. $M$ is an illiterate woman somewhere in her fifties, but because she is married to a rural school teacher she is given the title Bu Guru. $S$ and $P$ are not wealthy, but are considered to be of higher status than $M$. $S$ and $P$ are in their thirties. In the course of the conversation an elderly neighbor (K) drops in to deliver jack-fruit stew which he picks up for S's family every afternoon. The conversation is in Madyo, but Bu Guru (M) speaks the best Kromo that she can muster.

1. P: Mesthiné, yhô, susah lé kôn nyambot gawé barang kuwi.

2. M: Mbôten, mbôten. Nggéh pôkôqé lé kerengan niku.

3. P: Ha séng marai.

4. S: Môngkô nèq kulô, nèq ngajari bocah, bocahé nggéh kulô, wét riyén, ciléq niku, ajar-ajarané ngôten, ajari nyambot gawé tenan, ngôten. Kôyô Wit niku, cobô ...

5. P: Sésoq Wit niku, nggéh bisô dinggô dhéwé, Budhé.

6. M: Enjéh.

7. P: Njor, Es Em A lulos, engko teros raq isô nyambot gawé, soq dadi wông tuwô $\mathrm{njoq}$ prigel. Kepèpèté ra ngingu bator, isô. Lha ngôten niku. (to visitor) Nggô, Mbah.

8. K: Nuwon.

9. P: Mriki.

10. K: Enggéh.

11. P: Niku, Wit niku pon rôdô mayar, "Saqiki aku genti ngandhani Prôbô," kulô niku ngôten. "Nèq dhô mapan, apéq-apéq, séng dhô ngundhoh kowé dhéwé."

12. $\mathrm{M}: \mathrm{Nggéh}$.
1. Of course it is not easy for him [my husband] to keep telling him [Probo] to do the chores.

2. Oh, no, no. The problem is that they quarrel.

3. Well, that is what starts it.

4. That's why when I raise children, I teach them from the very beginning --teach them how to work properly, you know what I mean? For instance, look at Wit [my daughter].

5. In the future Wit will be able to manage by herself, Auntie.

6. Yes.

7. When she has finished high school, she will be able to work alone. She will be the sort of person that can do things. In case we cannot afford to keep servants, we still can manage. That's what I mean. [to the neighbor, $K$, who is delivering the stew] Come in, grandfather!

8. Excuse me.

9. Come in.

10. Yes.

11. Wit is already fairly well trained. Now I had better turn my attention to Probo, I said. "When you are all settled, well settled, you yourself are going to reap the rewards." 
13. P: Riki, Mbah, ngriki. Kulô tepangké: niki ibuné Prôbô.

14. M: Nggô.

15. K: Niki tumbaské.

16. P: Nôpô, Mbah? $0, \cdot$ gudhek, o inggéh! Néng urong mbayar, jé (laughs)!

17. S: Niku bapaq kulô hé (laughs)!

18. K: Néng wés ra ndé endhôk (laughs)!

19. K: Pripon putrané?

20. M: Ha nggéh, ha wông adaté menikô wiwét rumiyén nikô, ugeré kerengan paben kaléh naq Wit nikô, raq nggéh ngantôs nyôq tangis-tang isan ngôten. Néng mangké ugeré sampon saé maléh, nggéh pon, mbôq nôpô-nôpô nikô nggéh uyung-uyungan cah loro nikô. wông wiwét rumiyén ngôten niku.

21. K: Nikô soqalé niku raq méng wingi niku raq ngôten; Wit niku ajeng mlebu sekolah.

22. M: Nggéh .

23. K: Ha njor Prôbô niku sampon diponweléng kaliyang mas Patemô, "Engko nèq sekolah, engko ôjô sôq mampér dolan. Teros muléh, perluné nggantèni mômông." Wit mlebu sekolah.

24. M: 0 , njéh.

25. K: Dientôsi ngantôs jam siji kliwat.

26. M: Setengah kaléh gèq tekô.

27. K: Lha enggéh, mbôten mantoq. Ha Wit raq mlebeté jam siji. Sek ajeng mangkat, Ana pon nglilér, mbôten let ...

28. M: Mbôten mlebet.

29. K: "Mboq, lho iki ôjô ditinggal. Pôkôqé, nèq anu, njot gelô," nggéh? Mesaqké bocahé.
12. Yes.

13. Come over here, Grandfather. Let me introduce you: this is Probo's mother.

14. Hello.

15. Here, I bought it for you.

16. What is it, Grandfather? Oh, jackfruit stew! Oh, yes. But I haven't given you the money (1aughs)!

17. "This is my father, you know. [He means, "This is our neighbor who is like a father to me."]

18. [apologizing because he bought the cheap kind of stew, without eggs] But I bought it after the eggs were all gone (laughs).

19. [to Probo's mother] How is your son doing?

20. We11, you know it is normal. It's been that way all along. When he gets to quarreling with Wit, they get to where they both start crying, you know. But when they get on good terms again, whatever there is to do, they do it together, those two children. It's always been like that.

21. But the problem is only that yesterday it was like this: Wit was going to go to school.

22. Yes.

23. Well, Mrs. $P$ had already scolded Probo several times: "When you go to school, don't stop to play anywhere. Come straight home. You have to take care of the baby because Wit is going to school."

24. Oh, yes.

25. She waited for him until after one.

26. He didn't get home until one thirty.

27. Well, yes. He didn't come home. Now Wit goes to school at one. She was already about to leave and Ana (the baby) had woken up. Not long after...

28. She didn't go to school. 
30. M: Nggéh .

31. K: Wông bocahé, nèq jéng momông bocah-bocah kuwi, yhô nèq dijaq angger wông gelem, karepmu.

32. M: Lha nggéh.

33. K: Dadôsé, mbôten mlebu.

34. M: Lha tôsipon badhé wangsol ngaten, néng mbôten mangertôs mbénjéng-mbénjéng, embèn-embèn menawi sowan mriki maléh, nggéh mbôten mangertôs, wông bocah. Wông wiwét wônten mrikô rumiyén anggeré kerengan lé ngantèq téng regejek, njor dhô tangis-tang isan nikô.

35. S: Mulô niku, wông empon kulô bagé tugasé.

36. M: Enggéh.

37. $s$ : "Ki, nèq soré, nggentèni, nggentèni mômông. Nèq ésoq bar nyapu ..."

38. P: Séng mesthi gèq anu, ôpô ... (simultaneously with above)

39. S: "Engko kwé ki, nggôdhôk wédang, kôn nggôdhôk wédang. Engko séng nggawé, ibuné. Nèq uwés, ngisèni kolah. Néng laq kolah genthông."

40. P: Kulô nganti sôq ... (simultaneously with above)

41. S: "Kolah genthông, mulô séng ciléq, wông séng gedhé Wit. Séq kolah njôbô, nggo ados ki méng genthông." Méng ngôten niku.

42. P: "Wit ki ngisèni kolah gedhé lho, Prôb. Kowé méng ciléq," ku1ô ngôten. "Kowé cah lanang kuduné isô kebaq." Ngger anu gèq, péng limô ngôten, gèq mandhek, bal-balan, dhil-dhil (laughs). "Prôp, wés durong?" "Dèrèng, nggéh!" Thiq-thiq-thiq (laughs). Aku $k i$ raq sôq ngantèq ngguyu nèng njonting kaé (laughs).
29. [quoting Mrs. $P$ when she gave instructions to the children] "Don't leave her (the baby). The thing is if, umm (the baby wakes up and you are not there), she' 11 be upset, you know what I mean. Poor child!"

30. Yes.

31. "As far as the baby goes, she' 11 let anyone take care of her so long as it is one of the children. So I leave it to you (which of you will take care of her)."

32. Of course.

33. So, she didn't go to school.

34. Well actually, he (Probo) was going to go home (i.e., leave $S$ and $\mathrm{P}^{\prime}$ 's house), but he didn't know when and if he was going to come here again. He didn't know, because he is a child. Because ever since he was here before, if they fought, it would get rough, and then they would start crying.

35. That's why I divided the jobs.

36. Yes .

37. "Here, in the afternoon you take her place in watching the baby. In the morning after you have finished sweeping..."

38. It's always the case that...

39. [quoting what he said to Probo] "Now you, you boil the water. Your $\mathrm{job}$ is to make hot water. Mother will make the (tea). After that fetch the water for bathing. All it is is a water jug to fill, you know."

40. Sometimes I get to the point that...

41. "The bathroom just has a water jug, so it is just a small jug. Wit will do the big one. The water container outside for bathing is just a jug. That's all there was to do!"

42. "Wit filled the big tank, Prop. All you have to do is the small one." That's what I said. "You are a boy, you should be 
43. K: Sekécaqaken rumiyén.

44. M: Nggéh, njéh.

45. S: Lha kéngéng nôpô niku as tané?

46. K: Non? Wông méng kulô buntel, gor ngôngôti damel sapu.

47. S: 0. Nèq kulô dhéwé niku malah arang-arang ngandani Proboo niku. Nèq kulô ngandani, "Nèq soré kuwi, nèq wés kesel, sinau, môcô, golèq buku. Kuwi, diwôcô."

48. P: Kulô niku ngerti, Prôbô niku nèq dikandhani bapaqné mesthi wedi sanget. Mulané.

49. S: Kulô mbôten tau ngandani malahan.

50. P: Malah arang-arang.

51. S: Kulô, soqalé, yhô bèn mapan dhiséq, lé ngandani alôn-alôn, nèq kulô, ngôten niku. Néng méng kulô pasrahi gawéan-gawéan niku.

52. P: Nèq ésoq, nglapi hondha, nglapi pit.

53. S: Niku men ora mesthi, nèq mbôten dikôn mbôten klapan (laughs). Gelem nglapi, yhô wés ora tapés (laughs). Ha nggéh kulô balèni maléh, kulô nggéh pon ...

54. M: Wuatôn, watôn, watôn nyandhaq gombal, ndumoq, wés!

55. S: Séng penthéng kulô niku mong ndhidhéq bèn ngerti ajek ngôten lho, kewajipané ngôten niku. Dadi ora reséq, yhôs bèn, engko taq pindhônané. Néng kudu, kudu nandangi, karep kulo ngôten niku.

56. P: Nggéh. Sôyô nèq ésoq niku, Budhé. able to fill it full." After only umm, five bucketfuls, he quits, plays ball, bump-bump (laughs). Sometimes I have to laugh, but it is annoying (laughs).

43. (Taking his leave) Bye!

44. Good-bye.

45. [He notices that the neighbor's hand is bandaged] What happened to your hand?

46. Pardon? Oh, I just wrapped it up because I am going to chop some sticks to make a broom.

47. Oh! Actually, I rarely scold Probo. If $I$ do say anything, (it will only be like this): "In the evening, when you are tired of studying, read, look for a book to read. Why don't you read that there?"

48. I know that when Dad scolds Probo, he surely will be scared, so...

49. But actually, I never scold him.

50. Actually, very rarely.

51. I only want him to find his way. I teach him a bit at a time, that is all I ever do. But I do give him chores to do.

52. "In the morning wipe the motorcycle, wipe the bike."

53. He doesn't even necessarily do that. If we don't remind him, it won't get wiped (laughs). Oh, he is willing to wipe it, but it comes out streaked (laughs). OK, so I do it over again. I already...

54. So long as he takes the rag in hand, wipes a bit...

55. The important thing is that I train him so that he always does it, he knows that that is his responsibility. So if it isn't clean, never mind, $I^{\prime} 11$ do it again. But he has to do work. That's what I want.

56. Yes. Especially in the morning, Auntie.

57. It is the same with sweeping. 
57. S: Nyapu niku nggêh ngôten niku ... nyapu niku nèq mboten dikôn .... Ha sér kulô niku, nduwéô ngerti dhéwé, ngôten. Ha nèq anu, nggéh, ibuné nyapu, ngôten niku.

58. M: Nggéh. Mangké nèq jéng akôn naq Wit mbalah padu.

59. S: Enggéh.

60. M: "Mbôq bèn, mbôq bèn!" mesthi ngôten niku. Es ...

61. S: Ha wông Wiwiq, Niniq niku men pon kenô dipasrahi ngliwet, asah-asah, nggôdhôk wédang (laughs). Mangké marai bocah nèq ora tau dikèqi gawéan, dipasrahi gawéan, ngôten, ngko ora ngerti tanggong jawap. Teros kugong. Ngko nèq arep rekôsô sithéq, wés wegah. Môngkô kahanané ki ra mesthi, nggéh tô?

62. M: Nggéh.

63. S: Yhô nèq saqiki, iséh kuwat dhané iséh wông ...

64. M: Inggéh.

65. S: ... wông tuwané, wông tuwané kuwat ngingu réwang. Lha nèq kepèpèt! Mulô laré-laré niu mon kulô pasrahi gawéan. Lha nèq tangi niku, nèq séng nggugah Wit, ora gelem tangi.

66. P: Ora gelem tangi tenan, Budhé.

67. S: Pripon!

68. P: Kudu aku séng ndemôq.

69. M: Méng ngolat-ngolèt nikô mesthi.

70. S: Enggéh.
If he isn't told to sweep... What I want is for him to understand by himself. If Mother sweeps, he should do the same thing.

58. Yes. But when Wit is the one who gives the orders, they will fight instead.

59. Yes.

60. "OK, OK," I'm sure that he would answer like that. So...

61. Now Wiwik and Ninik [the other children] can be trusted to cook the rice, wash the dishes, heat the water for tea (laughs). But if you have children that are never given anything to do, don't have chores assigned to them, they won't develop any sense of responsibllity. They become spoiled. So if you ever have the slightest financial problems, they won't want to do their share. You know, we aren't necessarily always going to be in this situation [wel] off], right?

62. Yes.

63. Well, probably at the present time, they probably can, if they are still...

64. Yes.

65. If the parents are still able to afford servants. But if they should get to have financial problems, ... so I have given these children chores to do. Now when he gets up, if Wit wakes him up, he does not want to.

66. Really, Auntie, he does not like to get up.

67. What can I do?

68. I have to be the one to shake him.

69. He probably just likes to stretch a bit.

70. Yes.

71. Hmf. He kicks with his feet. Anyway, that is what it is. But I really get annoyed the 
71. P: Malah njejaqi. Pôkôqé empon. Sengit aku ki jan, lé gethingan karo Wit ki. "Kôg lé tenanan!" kulô niki ngantôs sôq ngôten. 0 , Allah!

72. M: Naq kaléh kulô, mbôten criyôs nôpô-nôpô. Nggéh méng tekô, "Bu!" "Heh?" "Pité niku ilang, séq kulô gôwô wingi." "Ha ilang $\mathrm{ki}$ wingi, tôq sèlèhké ngendi?" Lé mangsuli, "Taq gôwô, taq balèqké, yhô selèkké kandhang." "Ha nèq bengi barang ki, yhô, pit selèhké kandhang, tô?" "Mbôten. Nggéh lebôqké ngomah, néng wingi kulô kèqké kandhang. Kulô nggéh pamét Nor, 'Wés yhô, Nor!" Wông Nor niku mungel ngôten: 'Jra, Prôbô kôq lé ibut ki ngôpô?"' Ngôten bar didangu 'Prôbô kôq lé ibut ki ngôpô,' ngôten niku. Kulô nggéh, méng kôndhô, 'Wés, yhô Nor. Aku arep bali. Engko mator ibu.' 'Yhô!' ngôten niku Nor."

73. S: Ha wingi kulô wedèn-wedèni, "Piyé kowé wing1? Kowé iséh arep bali ngalôr ora?" kulô ngôten. "Mbôten." "Ha nèq ora bali ngalôr, yhô pité dibalèqké ngono!" kulo ngôten. "Lha pon kulô wangsolké, kôq!" "Kôq balèqké ngendi, wông ra ônô!" "Ong empon, kôq!" "Lha séng kôq pasrahi sôpô?" "Enor." "Lha Nor ki raq ra ngerti gèq lèhmu ndôkôq ngendi." "Teng nggèn kandhang." "Ha kuwi, Wit ônô mburi, gèq séng nèng ngarepan méng Nor. Ngerti kowé ndôkôq sepédha, mesthiné diliréq uwông, dijikoq nguwông. Kowé kudu ngijôli!" (All laugh.) way he can't get along with Wit. Why do they have to go after each other? Sometimes I get to the point that I... Oh, God!

72. [Changing the subject] Well, he did not say anything to me (when he got home). When he came he only said, "Mom!" "Yes?" "The bike disappeared, the one $I$ was riding yesterday." "Where did you put it yesterday?" He said, "I took it; then I brought it back. I put it in the compound." "You mean even at night you just put the bike into the compound?" "No, I put it inside the house, but last night I put it in the compound. I told Enor [a boy in the house] I was going out again: 'Bye, Nor!' Nor said, 'How come you are going off? What is that you have to do?' " That is all. He asked Probo what he had to do [that he was rushing off]. That's what he [Probo] said. "I just said, 'Good-bye, Nor. I'm going home to my house. You tell Mrs. P.' 'OK.' That's all that Nor satd." [I.e., when Probo brought the bike home he did not put it in the house, but rather he left it in the yard without mentioning it to anyone. All he did w.s tell one of the boys in the house that he was going home to his mother. But he failed to mention that he had left the bike outside.]

73. Yes. Last night I put a fright into him. "What do you want to do? Do you want to go back to your mother's, or not?" I said to him. "No!" "Well, if you don't want to go home, just put the bike back." That's what I said. "I did return it!" "You did? Well, where is it if you returned it?" "Well, I did 
74. S: Kulô wedèn-wedèn1, "Kwé engko nèq angger ora gelem ngijôli, taq laporké pulisi, maturô ibu, yhô!" kulô ngôten.

75. P: (laughs) Mas, unjuqané (laughs). Budhé, diunjoq Budhé!

76. M: Enjéh.

77. S: Ha kajeng kulô ngôten; niku sér kulố nggéh bèn ôpô, nggéh bocahé bèn ngerti cara-carané piyé. Nèq padhané wés ora seneng, ...

78. M: Nggéh .

79. S: Ngôten, nggéh tô?

80. M: Enggéh.

81. S: Ha kulô môngkô ora ngerti sebab-sebabé ôpô. Naq Wit kôndhô-kôndhô ngéné-ngéné, yhô wés ra taq percôyô, wông ngko, padhané kerengan ngono, ndhèqnèn méng mbenerké awaqé dhéwé, nggéh tô?

82. M: Enggéh.

83. P: Dadi, iki nggo nggamblangké (laughs).

84. S: Kulô méng ajeng ngerti dhôngé ki kepiyé ngôten. Lha nèq penjenengan rawoh, mengko raq kulô isô ngerti lara-larané kepriyé. Mesthinipon raq Prôbô raq mator, dumugi nggriyô, "Aku anu, anu ..."

85. M: Nèq kaléh kulô mbôten $\ldots$, wông nyoq kulô geguyu mawôn. Wataqé mnai kerengan, yhô kô ngono kaé. Ha kaléh Nyôtô, kaléh Mèdi, anu: "Aku ki nèq wulangané penoh, lèhku bali ki setengah loro. $\mathrm{Ha}$ tekan omah setengah loro. Mbaq Wit i selaq arep mlebu. Aku ki yhô, tekô, teros taq jaq, tô. Ana ki taq géndhông. Mbôsô anu, ngejaq Ana taq géndhông $\mathrm{ki}$, njot direbot tô sekô mburi ki, aku ki, yhô kagèt. Ha aku njor ..." so." "Well, who did you turn it over to?" "Nor." "Well, Nor does not know where you put it." "I put it inside the compound." "So that's it! Wit was out back, so the only one that was near the front was Nor. You know that when you left the bike, somebody must have been watching you. So he took it. You are going to have to replace it." (All laugh.)

74. I put a scare into him. "If you don't want to replace it, I'11 report you to the police. You had better tell your mother." That is what I said.

75. (laughs) Your tea, dear. Have some tea, Auntie.

76. Yes.

77. Well, that is what I would like to do. What I mean to do is, umm, so that the child knows how things are around here. For example, if he is not happy, (he doesn't have to stay on).

78. Yes.

79. Don't you think that's right?

80. Yes.

81. Well, since I don't know what the problems are... When Wit says it is like this or that, of course, I don't believe it, because, well, if they were fighting, she is surely going to justify herself, right?

82. Yes.

83. So this is just to get things out in the open.

84. I only want to know what the facts are. So when you came, I could find out his side of the story. Probo must have told you when he came home, "I did so. and so and so."

85. Actually, he didn't [say anything to me]. I just joke with him. That's the way he is when he has fought. He said to Nyoto and Medi: "I don't get home until half past one on 
86. S: Nèq Wit lé ômông niku anu, "Wông kulô kèn mangan dhiséq, gèq Ana dijaq," ngôten. "Saqniki raq lé ngajaq Ana, raq saqdurongé mangan."

87. M: Enggéh .

88. S: Niku. Lha niku karepé Wit, niku lé kôndhô ngôten niku. "Wông kulô kèn nedhô riyén, malah, nganu, mbôten puron, teros Ana kulô..."

89. P: Ana $k i$ arep dijaloq Wit ki ra èntoq. Pancèn ngéné.

90. S: Lha 1yhô. Karepé ki kôn mangan séq.

91. P: "Ora sah, ora sah kôq jaq, Prôp! Taq jaqé, aku nyambi mbaq Ana, isô. Néng kowé nimboô."

92. S: "Mangan dhiséq," ngono, "kôn mangan."

93. M: Nèq lé criyôs kaléh Nyôtô nggéh nikô, "Aku $k i$ yhô wés ngerti mbaq Wit ki kewengèn, wồng lèhku tekô wés setengah loro. Ha kuwi, aku ki teros ngejak Ana. Ha kôq njor muni ngono ki, 'Taq ajaq ki teros.' Dijaq sekô mburi. Wông Nor ki kôndhô, 'Prôp, kowé kôn mangan séq, kowé kôn madhang séq.' Ha aku ki, yhô nganu, ora madhang séq, wông mbaq Wit ki selaq kewengèn tô, wông lé mlebu jam siji, setengah loro. Ha malah mbaq Wit ki lé muni ki, 'Kônô nèq arep dolan, yhô dolanô kônô! Wés ngerti nèq aku ki mlebu jam $s i j i$, ndadaq dolan!' Lé mungel ngôten menikô. 'Wés ngerti tô nèq $a k u$ ki mlebu $j a m$ siji, kôq ndadaq dolan! Wés, dolanô teros kônô! Kéné Ana taq jaqé. Aku nyambi-nyambi yhô isô." " days that I study full time. So I came home at half past one. Wit was about to go to school. When I arrived, I immediately took Ana. I picked her up. Then she came from behind my back and she grabbed the baby from me, so I was taken by surprise, so I..."

86. Well, what Wit said was, "I told him to eat first, before he took Ana." That's what she said. But he went and took Ana before he ate.

87. Yes.

88. That was it. That's what Wit meant. She said, "I told him to eat beforehand, but he didn't want to. So I [took] Ana..."

89. Wit wanted to take Ana, but he wouldn't let her. Really, that is the way it was.

90. Of course. She just wanted him to eat first.

91. "Don't, don't take her, Prob, I'Il take her. I can take care of Ana while I do my other work. You just take care of the water."

92. She said to eat first. She told him to eat first.

93. The way he told it to Nyoto was, "I already knew that Wit was late. I didn't get there until half past one. So I took care of Ana immediately. So then she said, 'I'l1 keep on holding her.' She grabbed the baby from behind. Nor told me, 'Prob, you are supposed to eat first. You eat first.' Well, I didn't want to eat because Wit was about to be late, because she goes to school at one $o^{\circ}$ clock, half past one. But instead Wit just said, 'If you want to go play, go on, play! You know perfectly well that I have to go to school at one o'clock, but you just go and play [instead of coming 
Ngôten. Naméng ngôten niku lé criyôs kaléh Nyôtô. Nèq kaléh kulô, mbôten criyôs menôpô-menôpô. straight home].' That is what she said. 'You know perfectly well that I go to school at one, why do you fool around? All right, if you want to play, go ahead! I'11 take care of Ana. I can do it together with my other jobs!'" That is the way he told it. That is all he said to Nyoto. But he actually did not say anything to me. 


\section{Conversation 5. IN THE KITCHEN}

Three students in their early twenties who share a house are cooking together and then have their supper.

1. K: Wés mateng, Lép? o, taq
kôn nggolèq séndhôq é!
Ngéné iki ra isô mlenthong!
2. S: (Pretends to be acting in a
Kethoprak)
3. K: (About S's performance)
Bagos whaé! Saqik1 gèq
Oôong saru (laughs).
4. S: (laughs) $\quad$ Asem (Coughs) Tempiléng kowé! Tô kuwi! (Coughs) Ra méng mbôkô sij1!

5. K: (Sarcastic) 0, enggéh!

6. A: Séng és mateng end 1 (laughs)?

7. S: (Coughs) Wah, lé nggorèng wernô-wernô maraqké ...

8. K: Ngôpô?

9. A: Panas!

10. S: (Sings and then moves $\mathrm{K}^{\prime} \mathrm{s}$ shoulders back and forth in time with the rhythm)

11. K: Taq kentèl engko! Mataku ki lôrô. Nèq kejôngkôq yhô -...

12. S: (Singing) Esemmu anggeget ati, ayo ...

13. A: Iki sidô disambel ora $i k i$ ?

14. K: Sidô!

15. A: He? (Continues singing) Kemés-kemés kôq muléh ki ngôpô, Kés?

16. S: Ha?

17. A: Kôq muléh ki ngôpô Kemés?

18. S: Arep anu, rembokan, kangsèn ro wông tuwô-tuwô; kaé, séng taq kandhaqké kaé. (Goes back to singing)

19. K: Nyidham gawéan!

20. A: Nèq nggônaku malah Senèn séng ndhiséq kaé! Aku ki dhôngé ora olèh réné dhiséq!

21. K: (to A) Perlu ngôpô?
1. Is it done (the rice), Lip? Hey, I told you to get a spoon. It's never going to get done this way.

2. [Pretends to be acting in a Kethoprak performance]

3. [About $S^{\prime} s$ performance] Beautiful! Now tell us something dirty.

4. (Laughs) Darn! You want me to hit you? Why did you make only one at a time?

5. Yes, sir!

6. Which ones are done?

7. You' re cooking so many different kinds of things. That makes it...

8. Makes 1t what?

9. Hot!

10. [Sings and them moves $K^{\prime} s$ shoulders back and forth in time with the rhythm.]

11. Keep on, and $I^{\prime} 11$ hit you. My eyes hurt. If you get knocked over...

12. (Sings) Your smile touches my heart...

13. Am I supposed to make a chili out of this, or not?

14. Yes!

15. Huh? (i continues to sing.) How come you are golng home on Thursday, Kis?

16. Huh?

17. How come you're going home Thursd ay?

18. We're going to have a family discussion. I promised the folks back home, like I told you.

19. He's hankering for work.

20. I went home a week ago last Monday. Actually, I wasn't supposed to go back yet.

21. What did you have to do? 
22. S: (to K) Séq, séq, séq!

23. K: Engko séq, Kés!

24. S: Entèq kuwi. Wông ra ônô anuné, yhô ra isô apéq, kôq, yhô!

25. K: Isô-isô whaé! Kowé ki ra watôn. Lha niyat! Yhô ngerti nèq lengô larang tô, kowé ki? Jan, sèket limô jé, rumangsamu!

26. S: (Teasing $K$ ) Né bojomu menèh, yhô, tô, yhô?

27. K: Nang nggônné ...

28. S: (laughs because he managed to annoy K) E1ho, 1ho, lho, tho!

29. K: Wèh, kowé ki wés!

30. S: Lho, lho, lho, lho!

31. K: Cemburu, tô?

32. S: Wo, ora, ora! Séng cemburu ki sôpô? Kôn njôtôsi pô piyé?

33. $\mathrm{K}$ : Lho ...

34. S: Ha ngarani wông kôq watôn (sings)! Emèqen! Emèqen (laughs)!

35. A: (laughs) $E$, nèq kowé yhô ra isô ngemèq!

36. K: Kaé ki és ônô séng nduwé!

37. S: Nha géné ngerti (laughs)! Kôq méng wông muni ngono wé nj or ...

38. K: Kowé sér, pô, kowé Kés?

39. S: Lôrô atiku (laughs)!

40. A: Séng, séng anu, kulôn ndalan?

41. K: Séng Es Pé Gé kaé?

42. S: Séng Stèla Dus héé? Séng anu ké ra sekolah, kôq.

43. K: (laughs) Ra dhông nèq njor ra sekolah ki!

44. S: Elho, néng yhô, ra élmiyah, yhô Lép?

45. A: Néng yhô ra sekolah tenan kétôqé.
22. (To K) Just a second.

23. Just a second, Kis .

24. It's all gone. Because there isn't any whatchamacallit [oil]. It's not going to come out good.

25. It is so! You don't know what you're talking about. What do you want me to do? Waste oil? Don't you know oil is expensive, you idiot! It's fiftyfive, you know.

26. (Teasing $\mathrm{K}$ about going home) You're going back to your wife [actually sweetheart], $\operatorname{aren}^{\prime} t$ you?

27. To my...

28. Oh, oh, oh (teasing him).

29. Hey! You're (jealous).

30. Oh, oh, oh!

31. You're jealous, aren't you!

32. Hell no! Who's jealous around here? You want me to punch you in the nose?

33. Hey!

34. You say whatever comes to your head about people. (Sings.) You can take her (your sweetheart), I don't care!

35. You are not allowed to touch anyone.

36. I don't like her. She's somebody else's girl.

37. Oh, so you do know who I mean! All I did was say one word, and you...

38. You like her, Kis? You like her?

39. You're insulting me! (laughs)

40. You are talking about the one that lives to the west of the highway?

41. The one that's studying in the teacher's training institute?

42. The one that stays in the Stela Dus (dormitory). She isn't going to school.

43. I don't know why she doesn't go to school.

44. She's not educated, isn't that so, Lip?

45. But apparently she's not 
46. K: Séng endi? Séng elôr?

47. A: Séng kidol!

48. S: He-eng!

49. K: 0 , ora!

50. S: (eating) Genah aku, aku wingi weroh nang pasar, kôq. (Changing the subject matter) Gèq dilèr séng iki!

51. K: (Orders someone to get a spoon) Cowèqé!

52. A: Aku méng mangkel ki mbiyèn kaé, és tau weroh ki yhô taq ngetké ngono $k 1$ méngo anèh. Bajingan! Aku mangkel lé, aku é, ngono ki!

53. S: (About the water in the kettle) Ku mau és umôp?

54. K: Wés!

55. A: Ik1 gèq ra sedheng segané?

56. K: Sedheng whae! Arep dom-dom yhô dilèr! Uwés Kés, lé, lé nggorèng $\mathrm{ki}$ seméné whaé!

57. S: Lha uwés yhô uwés! Séng yhô arep nggorèng enèh $k i$ yhô sôpô?

58. K: Kôq kresek-kresek?

59. S: Aku raq méng ômông dhéwé, tô (laughs)? (laughs about the frying pan) Dhoh adhoh, disambel yhô brambangé?

60. K: Ko ko ko! (Alip leaves the room for a minute) Lha Alép mau nôndi?

61. A: Ha lé muni ra digorèng!

62. S: Brambangé k1 digorèng. Sôpô séng ômông?

63. A: He?

64. K: Sôpô séng kôndhô ra digorèng?

65. K: Ha yhô ra umom. Lha kồ kowé ki.

66. A: Lé muni ra sidô nyambel.

67. S: Yhô isô. (At the same time as above) Séng kôndhô sôpô?

68. A: Séng tengah iki?

69. S: Karnôtô, pô?

70. A: He-eh! really going to school.

46. Which one? The one that lives toward the north?

47. The one in the south.

48. Uh-huh.

49. Oh no!

50. I know for sure (she doesn't go to school), I saw her in the market. [About the food] Leave them out (don't put them away).

51. Let me have the spoon!

52. I really got mad once. I knew who she was and looked at her, but she turned her back. The little... I really get ticked off at stuff like that.

53. Has it (water in the kettle) already come to a boll?

54. Yes.

55. This is not going to be enough rice.

56. It's enough. We're going to divide it up. Spread it out (to cool). It's enough, $\mathrm{K} 1 \mathrm{~s}$. Just fry this much.

57. I know, I know. Who said I was going to fry any more?

58. What's that you're doing (lit. making that rustling noise)?

59. I was just talking to myself. (S and $\mathrm{K}$ laugh) Hey! Shall I make the onions into a chili sauce, too?

60. Just a minute! Where did Alip go to?

61. Well, you said you weren't going to fry them.

62. We have to fry the onfons. Who said (we didn't)?

63. Huh?

64. Who said we don't have to fry them?

65. Well, it would be strange not to fry them. Why wouldn't you (fry them)?

66. Well you said you weren't going to make chili out of them.

67. Of course I can. Who said (I wasn't)?

68. The one sitting in the middle. 
71. K: Lha kôq ra sidô ki ngôpô, tô?

72. S: Dhô ra doyan sambel Karnôtô? Ha dinganu whaé.

73. $\mathrm{K}$ : IkI golèqnô wadhah, golèqké wadhah!

74. S: Ha?

75. K: Iki golèq wadhah!

76. K: (About a song at school) Nggônaku yhô séng maraị yhô rômô Mọlan hé.

77. S: He?

78. K: Giyat tenan.

79. S: He-he? Hô-ô ?

80. K: Hô-ôh .

81. S: Ha yhô és, ha nèq nggônaku ...

82. $\mathrm{K}$ : Tandha-tandha dhinamika kaé. Wa, giyat tenan.

83. A: Rômô sôpô? Polan?

84. K: Molan!

85. S: Ampuan pô?

86. K: Néng ra isôq. (changing the subject matter to frying) Lho, lha kôq tôq ...

87. S: He?

88. K: 0 , tha édan kui!

89. S: Engko digorèng anu whaé.

90. K: 0, iyhô.

91. S: Eq, gulané nganu, 1jéh, tô?

92. A: Iki, gulô iki, wés reget. Péng pirô whaé iki?

93. S: $\operatorname{Ra}$ pô-pô, méng ... Woo, bawangé rong ônô, yhô? (K sings.) Cepet ... cepet ... cepet-cepet! Wo, wo, wo!

94. A: Aku mau, dhèq nông Kotabaru mau, Lôndôné dhô tekô é, séng ndé omah ndhiséq. Ehm, anu, iséh ciléq-ciléq, limôlas taon. Kènèqé (showing the chest) iséh rôtô kôq .

95. K: Apané?

96. A: Hô-ôh, hô. Néng és gedhé-gedhé.

97. S: Apané kuwi?
69. Karnoto?

70. Uh-huh .

71. Well, how come you didn't do it them?

72. None of you like chili sauce, Karnoto? Well then just...

73. Here find a dish for them. Find a dish for them.

74. Huh?

75. Here, look for a dish.

76. (S sings a song which reminds $\mathrm{K}$ of a song in school) The one who teaches (singing) is Father Molan.

77. Huh?

78. He's really energetic.

79. Oh yeah?

80. Yeah.

81. Well, OK. But in my school...

82. That shows how dynamic he is. He really is energetic.

83. Who is that? Father Polan?

84. Molan.

85. Is he really good?

86. But he can't... Hey! How come you...

87. Huh?

88. That's a crazy thing to do.

89. Just fry them into a...

90. Oh, yes!

91. Hey! Is there any more sugar?

92. Here. Here's the sugar. It's gotten dirty. How many times has it gotten dirty?

93. It's nothing. Only... Hey you don't have the garlic in yet, do you? (K sings) Hurry, hurry. Oh-oh!

94. I was in Kotabaru a while ago. The Dutch people have come back--the ones that used to have that house. Her watchamacallits, you know, are still small. She's only 15. It's still flat [pointing to his chest].

95. What?

96. Yes, but she's already a big girl.

97. What are you talking about?

98. You know, her part here. It's still flat! 
98. A: Anuné, kènèqé kuwi (showing his chest) is éh rôtô.

99. K: (to S) Lha kuwi tambai.

100. A: Nèq wông kéné mono és gedhé. Néng rụpané barang ki iséh kôyô bocah ngono 1ho. (About the food) Lha kôq jangan seméné kôq ra sedheng nggo péq $\ldots$ sedinô, tô, yhô?

101. S: Ha eng, njaq anuné dhô ampoh, hé.

102. K: Wah! Watu!

103. A: Nèq aku setuju dudué okèh, nèq $\mathrm{aku}$.

104. S: He-eng. (A laughs.) Séq nggorèng ki sôpô?

105. K: Gèq gelés Kés, lha kowé ki kôq... Ra kô tumô kathôq. Wés taq tambai lengô ki... Mundhaq ki, saqiki larang, jé, saq ôn.

106. S: He-eng, he-eng ...

107. K: (Talking about the krupuk that is being fried) Saq ôn é mau. Saq ôn limôlas gélo mah rôdô murah iki.

108. S: Géné murah!

109. $\mathrm{K}: \mathrm{Ha}$ ?

110. A: Séng tuku kowé?

111. K: Lha njor dilanjari. (A laughs.)

112. S: Elho tho tho tho tho tho!

113. A: Aku sambelé ora aé. Ndhaq lôrô.

114. S: Ora yhô kenô. Ndi, ndi, nganuné mau? (K sings.)

115. A: Opô?

116. S: He-eh!

117. A: (Addressing Has, a man who lives in the same house, but is not a student) Dhô dèrèng tekô tô, Mas, nggèn njenengan niku?

118. H: Dèrèng! Dhô mboten mlebet. Markom nglajo.

119. A: Sinten?

120. H: Markom.

121. A: Kôq mempeng tô yhô, Es Té 0 ki pô ra kesel, pô yhô?
99. (to S) Hey put some more in there.

100. Girls from around here at that age already have something here. But hers stiil seem to be like a little girl's. (About the food) How come this much vegetables isn't enough for a day?

101. Huh, apparently hers are already quite interesting!

102. [Finds a pebble in his rice] Damn. A stone!

103. As far as I'm concerned, I like my veegatables with plenty of gravy.

104. Uh-huh. (A laughs) Who fried this?

105. Come on, Kis, hurry up. Don't be like a crab louse (that walks very slowly). I've already put the oil in here. Especially since this (krupuk) costs so much now. One ounce is...

106. Yeah, yeah.

107. I bought an ounce. An ounce was 15 rupiahs. Acutally that's cheap!

108. That is cheap!

109. Huh?

110. You bought it?

111. Did you get extra? (Alip laughs )

112. Hey, hey!

113. I won't have any chili sauce. I might get sick.

114. $0 K$, if you don't want any. Where did the whatchamacallit go to? (K sings.)

115. What? The spoon?

116. Uh-huh.

117. Your friends still haven't moved in?

118. No. They aren't enrolled in school. Markum goes back home at night.

119. Who?

120. Markum!

121. He sure doesn't mind exerting himself. Those enrolled in Phys Ed never get tired, do 
122. H: Justru lé Es Té 0 niku séng ra kesel.

123. S: Ha wông Katmô ki kadi Mangiran nglajo, kôq Lép.

124. A: Thô Es Té 0?

125. S: Hô-ôh.

126. A: Nèq Bejô kaé nglajo, tô? Bejôné dhéwé kaé, 1ho!

127. K: Hô-ôh.

128. A: Néng nganggo bèbèq.

129. K: Nganggo uthur raqan.

130. S: Nganggo uthur jenengé és kepénaq whaé, mbôq tekan -...

131. A: Lé muni dudu bèbèqé dhéwé ki kaé.

132. K: Duq, whèqé bapaqné kaé ... ponaqané.

133. A: Si umé!

134. K: Kaé Lép, iros Lép!

135. S: Eh, jan sedhep tenan. Alép doyan ora, Lép?

136. A: Ndhaq kumat.

137. S: (To A) Dhô dirasant wông kono kowé. Koé dhô dirasani wông kono.

138. A: Piyé?

139. S: Kulôn kono gebrès-gebrès .

140. A: Karebèn! (Changing the subject matter) Nèq mau séng maén nendi bal-balané.

141. K: Anuné gô réné, gô réné!

142. S: Es Té 0 karo Atmajaya.

143. A: Menang pô kalah?

144. S: Kalah Es Té 0, é anu, Atmajaya. Kalah ki enem. Mekakat tenan nèq ngono.

145. K: Iki nganggo sambel iki. Engko raq mar 1 njuran malaan .

146. A: Untuné teros mari?

147. K: Hô-ôh! Néng yèn ag i mangan $k i$ cèn senut-senut $k i$, ra pô-pô. Néng nèq és bar mangan, rasané ènthing kaé.

148. S: Jô dhéng Lép, ngko dapusi Karnôtô. Wè, Karnôto dinèi sambe1. they?

122. Yes. It's precisely those in Phys Ed that don't get tired.

123. Well, Katmo goes back and forth from Mangiran every day, Lip.

124. Is he also in Phys Ed?

125. Yup.

126. Bejo also commutes, doesn't he? You know, our friend Bejo?

127. Uh-huh .

128. But he has a motor cycle.

129. Actually it's just a motorbike.

130. If he uses a motor bike, $1 t^{\prime} s$ not so bad. You could go anywhere.

131. He said it was not his own scooter.

132. No. It's his father's. His nephew's.

133. His uncle's.

134. Hey, Lip, get the serving spoon.

135. (Sneezes.) Hey, it's really good. You like it or not, Lip?

136. I'11 get sick again.

137. They're talking about you behind your back. Hey! They're talking about you!

138. What do you mean?

139. They're sneezing in the other room (because of the stuff you are cooking).

140. Never mind. Where did they have the ball game [soccer]?

141. Bring the whatchamacallit here.

142. The Phys Ed School against Atmaj aya .

143. Did they win or lose?

144. Phys Ed lost, I mean Atmajaya. They lost by six points. That's too much!

145. Have some of this chili sauce. It' 11 make you better.

146. My tooth will get better?

147. Yeah. While you are eating it will throb a little, but it doesn't matter. But after you 
149. A: (Asking about a plate which formerly had a hole in it) Kuwi tôq tambal opô kôq buntet ki?

150. S: Heh?

151. A: Pô piréng liyô kuwi?

152. S: 0 ora, anggeré dudué ra okèh-okèh, yhô ra pô-pô.

153. K: (Tastes the food) Huh, énaq! Caq ra nggo enèh, tô iki?

154. S: Heh?

155. K: Uwés, nèq uwés anu gèq ndhônô!

156. S: Yhô ayo, engko séq.

157. K: Alép kuwi dingèngèl ora? Seg ané?

158. S: Ha kuwi sôpô séng arep ngentèqké.

159. A: Opô?

160. K: Kuwi, segané kuwl, iséh kuwi.

161. A: Wha, raq dhô rong warek, tô?

162. S: 0 ora, uwés .

163. A: Aku wés warek kôq wôngan.

164. S: Ha yhô uwés, yhô uwés, kôqWi, sambelé kuw!! Wah!

165. K: Gô mlebu whaé néngô. Opô tandoq?

166. S: (Knocking something) Wah, kegajol malaan.

167. A: Aku dhèq sepisanan dhéwé yhô méng gor nggorèng krupoq teros, jé.

168. K: Karebèn! have finished eating, it will feel good.

148. Don't, Lip. Karnoto is fooling you. Here give Karnoto some chill sauce.

149. [About a plate that had a hole in it] Did you patch this or did you just stuff something into it?

150. Huh?

151. Or is this a different plate?

152. Oh, no. As long as there isn't too much soup, it will hold out.

153. Um, good! You don't want any more, do you?

154. Huh?

155. OK, if you're done, pass it on (to me).

156. All right. Just a second.

157. Did you set any rice aside for Alip?

158. Who's going to finish it up anyway?

159. What?

160. There's still plenty of rice.

161. Aren't you all full yet?

162. It's enough. No, no!

163. We11, I'm already full.

164. Well OK, if you' re done. Here give me some chili sauce.

165. But put (the rice) away. Or do you want more?

166. You didn't put it away right.

167. When I first got here when I was alone, all I ever made was krupuk all the time.

168. That's g jod enough. 


\section{Conversation 6. PLANTING SUGAR CANE}

A conversation in a small town to the south of Yogya among (A) a 22-year-old student in the English program at IKIP Santa Dharma, his uncle (B) a foreman on a sugar-cane plantation, and another nephew of $B^{\prime}$ 's (C) a student in a normal school in Yogya, aged 20. Also present are B's wife (D), aged 28, and their two-year-old child (E). As the conversation begins, $C$ is trying to pump up a flat tire on his bicycle.

1. B: Nggo gombal plu!

2. A: Séng ciyut apané?

3. B : Ha yhô lému kebangeten, ngompô é ra tèyèng! Wèh, bong mati ki ambuné és kô badhek. Heh, mambu basengé ngethek.

4. C: Net menet, anuné, net-netké slébôr, dadiné bané ra kenô ditekem.

5. A: Karebèn mengko! Bapaq ki lé tandor kaé anèh kaé.

6. B: Piyé, wés tandor pô?

7. A: Separo agièn.

8. B: Nèq mah rong ndé winéh.

9. A: Kaé emboh, winié dhéwé, dudu kaé?

10. B: Ha iyhô, nggo nggawèqké.

11. A: Lha néng teros arep dikapaqké enèh kaé?

12. B: Ha yho ditanduri menèh. Lha njaq gawèqké winéh ngônô, jé kôq.

13. A: Diluku enèh?

14. B: Ha iyhô, kowé kôn macol, kowé.

15. A: Ha wông lé olèh banyu wé angèl káe.

16. B: Tawôni.
1. Why don't you try using a rag, you dope!

2. What is it that is making it too tight?

3. God, you' re really too much. You don't even know how to pump up a bike! Yuck, these old bamboo shoots sure smell like they're spoiled. Hmf, they stink to high heaven.

4. It is too close to the fender, so you can't get a grip on the tire. [He really meant the valve has gotten inside the tire rim, and he can't get a grip on it to screw the head of the pump on to it.]

5. Leave it be for the while. My father has a funny way of planting rice.

6. You mean he has already planted his rice?

7. Only half of it.

8. But they don't have any seeds yet (to sell to the farmers).

9. I don't know if (what he planted) was from our own seeds or not.

10. We11, they must have been. He had to have some to make the seedlings.

11. Then what are they going to do (with the field)?

12. You have to replant it of course, to produce seedlings.

13. Will they plow it again?

14. Yes! Your job is to hoe it. You have to hoe it.

15. It's a job just to get water for it.

16. You fetch water in buckets. 
17. C: Tawôni sekô Tlawông - Ha méng nglelôrô awaq nèq ditawôni.

18. B: Môngkô étongané, néng nèq aku, anggeré 'muléh sekô glidhék wés ora nduwé kekuwatan liyané mogaq-mogoq, karo turu. Nèq bapaqmu gandhèng iséh ...

19. A: Mboh bapaq ki saqiki nandi lé manggôn.

20. B: Yhô golèq winéh kuwi ag èqan.

21. A: Lha kôq, anu, ora bali nyang wétan njôgôdhayoh, tô?

22. B: Lha ngôpô? Tebu arep dirembang ki, jôgô!

23. C: Enaq, Léq, mbakomu?

24. B: Nglintingô, tô!

25. A: Néng urong dirembang tô, kônô ki dadiné malaèn?

26. B : Urong .

27. A: Hah, kétôqé tebuné 1ju-iju ki raq énaq tô, kônô kaé. Pô ônô wông séng nyôlông ng ono?

28. B: Ha ènèng whaé. Sregep!

29. C: Nèq kidol anu kaé malah saqiki legi, lho. Séng kidol Tlawông, kidol prapatan kuwl.

30. B: Ha tebu jé, tobaté kaé angger rusaq. Wingi é môngkô wadhang ngônô. Nèh sésoq ésoq pirang lèri, wétan Tangkilan kaé.

31. A: Wétan Tangkilan?

32. C: Wèh! Rikô Jan ra karuan Léq, wisan.
17. They get the water from the Tlawong (river). All it does is give you a backache to water it with buckets.

18. The way I look at it, after I've done my day's work in the $v$ illage-owned fields I don ${ }^{\circ} t$ have the strength left to do anything but sit around and then go to sleep. (I don't have the energy to get water in buckets for my own field.) But your father since he is still...

19. I don't know where my Dad is staying at the moment.

20. He's getting seedlings (for sugar cane).

21. Well, how come he did not go back to the east of Jagodayoh?

22. What would he do there? It's time to cut the sugar cane, so it has to be guarded.

23. Is your tobacco any good, uncle?

24. Help yourself!

25. So, they haven't cut the sugar cane over there yet, have they?

26. No .

27. Well, the sugar cane over there is nice and green, so it is good to eat, isn't 1t? Do people ever steal any of it?

28. Of course. They do it all the time!

29. The cane over to the south of whatchamacallit is sweet by now! $T_{L 1}$ area to the south of the Tlawong, to the south of the crossroads.

30. That's the thing with sugar cane. It's no good if the cane spoils. Yesterday alone they cut more than they could handle [so that some of it spoiled]. All the worse because how many truckfuls are they going to get tomorrow morning to the east of Tangkilan?

31. To the east of Tangkilan?

32. God! It's gotten to be a mess over there, hasn't it, uncle? 
33. B: Biyang-biyangané! Kaé iki mau karo dhèq séng ndhikéq dadiné olèh telong puloh wôlu 1èri. Yhô iséh mbejaji olèh-olèhané.

34. C: Nèq ngôten niku dianu séng nggarap, Léq? Diétong, jenengé $\mathbf{k I}$.

35. B: Ha-eng, 1ki garapané sôpô. Kurang pametuné ki mergô lé garap ôpô mergô kerusaqan ...

36. B: Emboh kaé tan Tangkilan ...

37. C: Saqnik1 raq dibalèni nandor, tô?

38. B: He-eh. Aku mbiyèn lobang baléq nem atos lobang é, jeléhku ra jamaq, dikapôqké rolas héktar (laughs).

39. A: Saqiki?

40. B: Ha iyhô rolas hèktar kaé.

41. C: Saqniki nunggu rolas hèktar nf eneng an?

42. B: Wông loro.

43. A: Karo paq Mar?

44. B: Sum!

45. D: (to baby) Taq nga ... taq anu, njukoq diyan, ko sikéq. Nggér kono whaé sikéq kowé, taq njukoq diyan.

46. C: Yhô kétôq ratan gedhé?

47. D: Nggér kono whaé taq njukoq diyan, disulet.

48. B: Nganti lé kuru. Lha piyé, mahgan kasèp ... (A laughs). Lha gèq két ésoq nganti jam ... (laughs).

49. C: Papat! Néng nèq é kulinô yhô ra kasèp jenengé.
33. It's crazy! That together with yesterday's--the left-over from before, makes 38 truckfuls! You could call that quite a harvest!

34. In that case, do they umm [hold responsible] the one who worked the field, uncle. I mean do they count (how much is produced)?

35. Yup. They figure out whose work $1 t$ is. If there is a shortage whether it was from the way he worked the field, or because of spoilage... [Further conversation about the business of sugar-cane planting is omitted here.]

36. I don't know about the field to the east of Tangkilan.

37. They are going to replant it, aren' $t$ they?

38. Yes. Last time I made 600 holes (for sugar cane seedlings). You can' $t$ imagine what a job! Twelve hectares--(enough to) make me fed up.

39. (What are you doing) now?

40. Those twelve hectares, like I said.

41. You have been given twelve hectares to take care of?

42. Two of us!

43. You and Mr. Mar.

44. Sum!

45. (To baby) Let me, let me umm, get a lamp. Just a second. Let me get a lamp. I'll put you down a minute.

46. Can you see (the field you are working) from the highway?

47. (To baby) Let me put you down so I can get a lamp to give us some light!

48. I've gotten thin (with all the work). How can I avoid it? I don't get to eat until late (A laughs). I begin in the morning and keep on until...

49. Four! But when you get used to it, it doesn't feel like it's 
50. B: Ha muliô jam siji ké apesé léku mangan yhô jam telu, wông yhô muléh yhô rong ônô ôpô-ôpô, wông wés kulino nèq ngliwet soré karo ésoq. (C laughs.)

51. D: (To the baby) Kéné sikéq! (To a11) Méng olèh "jô ndumèh"!

52. B: Wo tha ... Pèyèqé entèq?

53. D: Tèq!

54. C: Malah sip.

55. A: Malah awèt, kôq.

56. C: Lha si anu kaé?

57. B: Cangkiré kurang.

58. C: Si anu teng pundi, tồ?

59. B: Sôpô?

60. D: Noné mbahné.

61. B: Wèh, aku ki raq ra ndé batéh.

62. C: Teng kulôn?

63. B+C: He-eh .

64. B: Dhô mlayu ngulôn kabèh.

65. D: (to the baby) Taq njukoq cangkér, yhô lé?

66. A: Nèq aku saqiki malah dadi mundhaq lemu awaqku.

67. C: Klimés nèng kônô. Kowé mono wông wés tenang jé, kônô.

68. B: (Asks $A+B$ to eat the casava biscuits) Nyô, dirôgôh ngéné whaé.

69. A: Tor méng rôdô kesel aku nèq liburan iki.

70. D: (To the baby that is starting to cry) Kono whaé taq njukoq cangkér, taq njukoqké kakang. Taq njukoq cèrèt sikéq. late (to eat at four).

50. Even if I come home at one, the earliest I can eat is three. Because when I get home there isn't anything, because they are only used to cooking in the afternoon and in the morning (and not at noon).

51. (To the baby) You stay here for the while. (To the group) All you are going to get is cassava crackers!

52. Why, is the peanut brittle all gone?

53. Yes!

54. In fact, these (crackers) are more than enough!

55. These will last forever, in fact. [I.e., don't worry about running out of crackers. The ones you gave are so tough that we won't eat very many.]

56. By the way, what happened to what's-his-name?

57. You didn't bring enough glasses!

58. Where is what's-his-name now?

59. Who?

60. At his grandfather's.

61. They've all left my house.

62. He went to the west [the grandfather's house located to the west of the village]?

63. Uh-huh.

64. They all ran away to the west.

65. (To baby) Let me (put you down so I can) get some glasses, $O K$, son?

66. As for me, I've grown stouter.

67. You've gotten nice and sleek. The thing is you don't have to worry •

68. Help youself to some more (crackers).

69. But then I get to be lazy when it is vacation like now.

70. (To baby that is starting to cry) You stay here. I'm going to get some glasses. I'll get some glasses for Big Brother. I'm going to get the tea pot for a second. 
71. $B$ : Engko nèq kepèpèt ...

72. D: Nggér kono whaé, engko ndhaq tibô ayo.

73. B: Nèq dhông, yhô weteng ki gilôq mangsané côq ra uros sôqan; krôsô ngeléh yhô utang baqso (C laughs). Ha néng ora seneng, lé ...

74. C: Nèq baqso, baqso nikô, nôpô 1sô warek?

75. B: Ha yhô méq nggo imboh kekuwatan, jé. Yhô mbi nyawè1 ôpô-ôpô. Néng yhô arang banget.

76. D: Wés ngompô durong ki mau?

77. C: Nôpô, Léq?

78. D: Wés dikompô durong?

79. $B$ : Lha rong tèyèng $k i$ !

80. C: Mbôten isô, wông bané mèpèt, kôq.

81. E: Enjoq empingé!

82. D: Yhô, engko dhikéq.

83. C: Nèq kulô tibané adôh Léq, karepé ...

84. E: Njoq nèh iki.

85. D: Yôh, engko sikéq.

86. B: Dibenomké pô piyé wôngan?

87. C: Onten séng puron nggolèqké.

88. B: Luar Jawa pô piyé?

89. C: Luar Jawa! Wé, adôh! Lha néng pripon, nèq wés kudu ngôten, lha Bardi wé rong rampong niku. Ha wông Bapaq kI mesaqké jé lé ngragati $k i$, judhek éram, é.

90. D: (Giving the crackers to the baby) Nyôh!

91. C: Bardi angger njaloq dhuwét wés telat-telat whaé, ndahnô nèq, nèq ro aku barang njaloq, cah loro $\mathrm{ki}$, kepriyé, yhô?

92. B: Môngkô saqiki nyambot gawé $k i$, cah, angèlé ra jamaq.
71. When you're pressed...

72. You stay here, sweetie. You're going to fall, careful!

73. Actually, sometimes my stomach, there are times when it acts up. If I feel hungry, I buy some soup on credit (C laughs). But I don't like it, the way it...

74. Is soup, is soup enough to fill you?

75. Oh, it's enough to give me a little extra strength. You know, to give one something extra to bite on! But actually I do it very rarely!

76. Did you pump it up?

77. What did you say, Auntie?

78. Did you pump it up, or not?

79. He doesn't know how!

80. I can't because the tire is too close to the fender.

81. Give me a cracker!

82. OK, OK. Just a second.

83. If fate brings me to a far-off place, what I plan...

84. Let me have another one!

85. OK, OK. Wait a minute!

86. Why? Did you get a job offer or something?

87. Somebody is willing to help me find (a job).

88. Outside of Java or what?

89. Outside of Java! Oh, it's far! But what can I do, if that's the way it has to be. Bardi [his brother] isn't even done yet. It's really hard on Dad to pay our expenses. He is at the end of his wits.

90. (Giving a cracker to the baby) Here!

91. Bardi doesn't ask for his money till the last minute. It is all the harder if I also have to ask for money. If there are two of us, how can he manage?

92. But nowadays it is a terribly difficult thing to get work, believe me!

93. In fact, where does Dad get his income from? Just from that 
93. C: Môngkô hasilé bapaq ki nyatané endi? Raq méng kaé thôq, tô?

94. B: Lha saqiki ki bayaran, ngemplang, meksô ènèng séng kurang whaé ...

95. A: Simbôq $k i$ gawéané yhô méng grenengan. Lé ni ki "Séng dhô mangan isané méng mangan, séng oncal-ancul ki èq." Dhèq nglajo aku raq mben dinô mesthi krungu, néng nganti mangkel aku. Sôpô wôngé ra kuru. (B laughs.) Lha pô kôn maléng nèq aku ki?

96. B : (laughs) Dhengkolmu! Adoh atôsé!

97. C: Kulô yhô wés nembong bapaq, taq kôn njagani sangu. Tékat-tékatan lah! Cah, ndhaq ra arep mati nông paran, yhô ebén. (field of his), isn't that so?

94. Well, as for me, I have been putting off paying any debts, but even so I still can't make it.

95. A11 Mom ever does is grumble. She says, "The people who eat in this house, all they do is eat. The only one around here who does anything is me." When I used to commute to school, that's all I'd ever hear, till I got disgusted. Who wouldn't get thin under those conditions? (B laughs) What does she want me to do? Steal?

96. (Laughs) Sheet! Jeez, is this (cracker) hard!

97. I already told Dad to give me money for the trip. I'll just go, never mind. I'm not going to die abroad, (but if I die,) so be it. 


\section{Conversation $7 . \quad$ TALK IN THE FAMILY}

Conversation within a Peranakan Chinese family at home. The participants are the mother ( $M$ ), aged in her fifties, her two sons ( $H$ and $A$ ), both unmarried university students, a daughter-in-law (S), and the wife of a nephew (E), who is on a visit from Bandung. Also present are $E^{\prime}$ 's five-year-old daughter (F) and $S^{\prime}$ 's two children ( $K$ and $B$ ). The conversation takes place in Kudus, but the participants are all natives of Semarang, and their speech shows the features of Peranakan speech in Central Java. As the conversation opens, a Pribumi.woman (P) who is selling rice comes to the house. The conversation is in Ngoko Javanese as spoken by Peranakan with some Indonesian, with the exception of the rice seller, who speaks in Madyo Javanese.

1. M: Wés daq kamôt. Wés taq sôqé njero.

2. E: Rông minggu ntèq segitu?

3. M: Daq mesthi El. Nèq ônô bocah akèh tu, yha akèh.

4. E: Akih, yhô!

5. M: Menèh ndèq ônô Liu ndôq kéné.

6. E: Wa!

7. M: Sedinô ngliwet péng telu. (E laughs.) Péng telu.

8. E: Saqomah, cah saqmonosaqmono.

9. H: Di Semarang berapa, beras? Mundaq apa medon?

10. E: Mboh, daq tau tuku.

11. H: Cepèq lebih, yha?

12. P: Alah, ngono iku nôq Semarangô yhô kiriman kô kéné, wông ra tau nempor.

13. H: Ha lyhô cumaqé mundaqmundaq. Mundaq pirô, raq roh.

14. M: Duwité dadi pirô, Pén?

15. P: Yatrané? Kanggé patlikor nggéh patlikor. Patlikor swidaq pôtông kaléh ôn, Yoq. Pôtông kaléh, pôtông kaléh atos. Ngarani kulô, kirang kaléh ôn, Yoq.
1. It doesn't all fit in (the storage bin). I'll pour some inside.

2. You use up this much in two weeks?

3. Not necessarily, E1. If a lot of the children are around, we eat a lot.

4. An awful lot, isn't it!

5. (We even eat) more if Liu is here!

6. My!

7. We make rice three times a day! (E laughs) Three times!

8. There's so many children in one house!

9. How much is rice in Semarang? Is it higher or lower?

10. I don't know. I never buy it. 11. More than a hundred (per kilo)?

12. My! So, even when you are in Semarang you must get your rice sent to you from here because you never buy any there.

13. We11, of course. All it ever does is go up. How much it goes up, I don't know.

14. So, how much is it, Pin?

15. The money? For twenty-four (kilograms) it is twenty-four -- twenty-four sixty $(2,460)$, take off two ounces (for the sack). Take off two, take off twenty (rupiahs). I count two ounces off (for the sack).

16. If it is a hundred (per kilo), 
16. M: Nèq duwété satos, rông èwu patang atos, séng seringgét péng patlikor pirô?

17. P: Niki umboq sedanten.

18. E: Môsôq!

19. P: Maléh ha empon? Niku, 1ho!

20. E: Ngko njipoq nèh, dadi.

21. P: Lho, ha niku kulô kersané. Lha nggôné Buntô wés tuku niku, piyé!

22. M: Saqiki wés umom.

23. E: Umon, mamah ndèq duluô yha gitu.

24. H: Wés umom.

25. E: Tau mèlu wông? Tau mèlu wông $k i$ oraq pô-pô, nèq oraq tau mèlu wông $k i$ wés, wông kôyô ...

26. M: Môtô dô 1ôrô! Kôq pilek, yhô!

27. S: Mèmang ngono kôq, Maq.

28. E: Awaqé raq énaq, yhô?

29. M: Aku ki daq tau, môtô lôrô gèq iki tho, tuôné.

30. S: Tapi hawané, kôq Maq. Anuqé waktu itu yhô Syan gitu kôq, pilek. E, ôpô môtôné lồồ yhô, gaq teros anu, ôpô ...

31. E: Plepekan?

32. S: Heqe, plepekan, kôyô pilek-pilek gitu. Tapi jané ndaq kenô banyu, yha ndaq baéq, kôq.

33. K: Mi, Mi, Mi!

34. S: Opô?

35. K: Nguyoh.

36. M: Gatel-gatel môtô lah.

37. H: Ndèq ésoq wés ditambani durong? that would make it two thousand four hundred. Plus two and a half times twenty-four makes it how much? [The price is Rp 102.5 per kilog ram.]

17. This is all Umbuk (a good variety of rice).

18. I don' $t$ believe that!

19. Take some more. That (rice) there (is still for sale).

20. Then you'll have to go back and get more.

21. Oh, no! I've already made my delivery to Bunta (so I'm free to sell this). I leave it up to you.

22. [After $P$ has left. Talking about servants.] That's common these days.

23. It's normal. Mama already used to do like that even formerly.

24. It's normal now.

25. Has she ever worked for anyone before? If they have worked before, no problem. But if they have never worked, it's like...

26. My eyes hurt. I seem to have a cold!

27. That's not surprising, Mom.

28. You don't feel good?

29. I never... This is the first time I ever got sore eyes in my $11 f e$.

30. But that's the weather now, Mom. jyan's, umm, were like that too. He had a cold. Either he had an eye infection or if not that, then he had, what do you call it?

31. A stuffy nose.

32. Yeah, stuffy nose, like a cold of some sort. But if you don' $t$ wash it with water, it's no good.

33. Ma! Ma! Ma!

34. What?

35. I want to go to the bathroom.

36. My eyes are really itchy.

37. Did you put medicine in them 
38. M: Wés, wés taq tètèsi.

39. E: Wiwô wés kenô matané?

40. M: Ndaq!

41. E: Lha kôq wani cedaq-cedaqu?

42. H: Ndaq pa-pa, a. Séng kenô itu nèq itu lho, turu ndoq ranjang itu kan bantalé kenô; saya ndaq mau tidor -..

43. E: Hèqé kenôq! Aku ndiséq di Jakarta kena ôq; lungô dôkter.

44. H: Itu cepet nularé.

45. E: Nèq ngliaqi kena, padahal ndaq, yha! (H laughs.) Heqe!

46. M: Dhôkteré bilang, "Ndaq." Nèq kena tangané yha, nèq kena siniqé yha.

47. H: Ha iyha, bantal. Kaloq bantal itu kan ...

48. E: Dhôkteré bilang, "Ndaq." Pakèq kacamata barang, ndaq usah.

49. H: Ha kôq kôyô hépnotis, nèq gitu.

50. E: Wông nèq ndelôqi iki kétôqé ô anu gitu, tho.

51. M: Ha iyhô!

52. M: E Lyan pindah a, anuné mundaq E1?

53. E: Apa?

54. M: Bayarané.

55. E: A, mboh.

56. H: Pindah mana saqiki?

57. E: Né "Parbappan".

58. H: Bank jugaq?

59. E: Apa?

60. H: Bank jugaq?
37. Did you put medicine in them or not this morning?

38. Yes. I already put in my drops.

39. (to H) Did you get the eye infection, Wiwo?

40. No!

41. We11, how come you dare go near her?

42. Oh, it doesn't matter. You only get infected if you do something like, umm, sleep in the same bed, so you' 11 get it from the pillow. I don't want to sleep...

43. Yes, you'1l catch it. I caught it when $I$ was in Jakarta. I went to...

44. It spreads fast.

45. (I thought) you could catch it by just looking at (eyes that are infected). But actually, you can't. (H laughs.) Yeah!

46. The doctor said, "No. If you touch it with your hands. If this touches it."

47. Of course. Like a pillow. If you touch the pillow, it'll surely...

48. The doctor said, "No. You don't have to bother wearing glasses."

49. If it were like that (that you could get it by just looking), it would be something like hypnosis.

50. Because if you look at (an infected eye), if feels like whatchamacallit, you know what I mean?

51. Sure!

52. When Lian (E's sister) took a new job, did her

53. What?

54. Her wages.

55. I don' $t$ know.

56. Where did she move to?

57. To the Perbapan.

58. Is that also a bank?

59. What?

60. Is that also a bank? 
61. E: Ndaq. Yha obat-obatan Vik barang itu, 1ho.

62. F: Minom, mau minom!

63. E: Silèt Gol barang, kaya agèn-agèn .

64. F: Ma, Ma!

65. E: Piyé? Piyé? Piyé? Sini! Piyé? Piyé? Mama sint?

66. H: Bagian apa, Ciq? Administrasi?

67. E: Tapi kerjaqané adôh mbèq kôsé, mèh golèq kôs séng cedaq whaé.

68. M: Rôdôq ceraq .

69. E: Nggôné anu hé, Jatinegara pa mana, kerjané.

70. H: Yhô ntèq gé umbal bés (laughs).

71. E: Yan saqin1 samban luwéh, yha?

72. M: Apa?

73. E: Samban luwéh, yha?

74. M: Yan? Daq, ah! Samban.

75. E: Cepet, tho yha! Lumayan yha lagiqan, yha!

76. A: Mana? Masoq gèq duapuluh lima, yha wés mèh setaon, ôq .

77. B : Maq!

78. M: Héh!

79. B: Akuh njiléh selbètmu.

80. A: Mèh setaonan.

81. H: Tuju bulan.

82. M: Tuju bulan hé, E1.

83. E: Itu ndèq apa, yha?

84. K: Tuju bulan.

85. E: Wông pergi Jakarta kaé April, kôq.

86. A: Ndaq ah, Maret.

87. M: Maret, kôq.

88. K: Maret!

89. E: Maret tapi ahér bulan.

90. M: Pertengaan kiraqé, El.
61. No. It's a place for drugs like Vicks.

62. I'm thirsty. I'm thirsty.

63. They sell razor blales, like distributors of Goal blades.

64. Mama! Mana!

65. What is it? Come here! Oh, what is it? Oh, you want Mama over there.

66. Where does she work? In the administration?

67. But she works far from where she lives. She is going to look for a place that's close by.

68. A bit closer.

69. I think it is in, umm, Jatinegara or something like that, where she works.

70. So she spends all her salary on the bus (laughs).

71. How much does Yan (one of $\mathrm{M}^{\prime} \mathrm{s}$ daughters) get now? More than thirty thousand, doesn't she?

72. What?

73. More than thirty, doesn't she?

74. Who, Yan? Oh, no. Thirty (that's al1).

75. It's quick, isn't 1t. Not so bad when you think that she just started.

76. Why? When she first started she got twenty-five, and now she has been there almost a year!

77. Grandma!

78. Huh?

79. I want co borrow your napkin.

80. Nearly a year or so.

81. Seven months.

82. It's only been seven months, E1.

83. When was that?

84. Seven months.

85. Because when she went to Jakarta, it was April.

86. No. March!

87. It was March!

88. March!

89. March, but the end of the month.

90. Around the middle of the 
91. E: Yha, tapi ngajaré misih pa ndaq?

92. M: Ha itu ôjô éntoq sambènan, yhô daq ...

93. A: Daq cukop!

94. M: Daq cukop.

95. E: 0 , anu, nglèsi, yha?

96. M: Anu, kursus.

97. E: Sih nglèsi dané kursus?

98. M: Yha! Ha iku Iumayan éntoq imbôang. Daq gitu, yhô entèq.

99. E: Nèq soré, yha? Nèq soré, yha?

100. M: Yha! Ha daq gitu yha wés entèq, El.

101. E: Sebulané pirô?

102. A: A és sebulan, yha, méq sithéq, ah (laughs)!

103. E: (laughs) Yha ndaq, tõ! Paléng sithéq njiq nggtjéng.

104. A: E, ndaq ada!

105. M: Daq ada, E1.

106. E: Môsôq!

107. H: Wông cumaq saqkelas thôq.

108. E: Wông cumaq anu, yha.

109. A: Cumaq saqkelas thôq.

110. E: Wông cumaq saqkelas thôq, ô yha, paléng banter. Tapi yha lumayan, yha?

111. A: Lumayan.

112. M: Yhô méq kenô gé imboh ngono itu.

113. A: Nèq ngemongké bayaran thôq, yhô és ntèq gé kôs, wông -...

114. E: A, nggo tuku-tuku rôk, nggo mbayar-mbayar kôs, yha.

115. A: Kamaré é mèh kô jéng.

116. E: Larang yha, kamaré, yha?
91. Yes. But does she still teach, or not?

92. Well, if she doesn't have an outside source of income, she wont"t...

93. She wouldn't have enough.

94. She wouldn't have enough!

95. Oh, she gives, umm, lessons, doesn't she?

96. Umm, private courses.

97. She still gives lessons in the private school?

98. Yes. It's a good thing. She can get a little extra. If not, she would run out of money.

99. She works in the afternoon? In the afternoon?

100. Yes. If she didn't, she'd run out, E1.

101. How much does she get from it a month?

102. Oh, she doesn't get but a little bit from it in a month.

103. (Laughs) Oh, I doubt that! At least she must get twenty-five hundred.

104. Not that much.

105. It doesn't amount to that much, E1.

106. How can that be!

107. It's only one class.

108. Oh, that's all she teaches!

109. Yes, just one class, that's all.

110. If that is all she teaches, that's all she would get. But anyway that's pretty good.

111. Not bad!

112. Yes. It's just to get a little extra.

113. Well, if she were to depend on her salary, she would spend it all just for room and board because...

114. Yes, to buy dresses, to pay for room and board.

115. Just her room runs to nearly nine thousand.

116. Her room is expensive, isn't it? 
117. M: Kaô féng, gapé anu iku ôpô -...

118. B: Ma, bangon!

119. S: Mbôq banguni a, Sisil? Mbangunt ôrang aé inf!

120. E: Lho! Kôq metu?

121. S: Ora, iki mlebu iki, dib angun 1 .

122. E: Lho, piyé?

123. S: Fifi mau is ndaq? Ha? Is apa ndaq?

124. E: Belom ada satu jam kôq sudah bangon!

125. S: Lha yhô lekas is!

126. E: Heqe! Pipls séq, bar bangon tidor!

127. S: Hè? Yha! Sudah?

128. H: Ngko ngompol, ngko!

129. S: Bilang, a!

130. H: Tator, tator, tator, ngko ng ompol, ngko!

131. K: Ngko môq ngompol.

132. M: Aku ôjô mbồq ồpôli, yhô?

133. S: Saqiki, kaloq is bilang yha, ayo!

134. E: Ramboté okẻh ngono ôq, yha?

135. M: Kôyô rambot jagong.

136. S: Yha lumayan wés.

137. E: Rambot jagong yha, ndèq

138. $M$ : Hèqè. bayiné saqméné, yha?

139. S: Rupané hèlèq déwé.

140. E: Ayu ngono, oq.

141. S: E, ayuné nyô ôpô? Ik1!

142. E: Fifiné.

143. M: Irongé amblek ngéné, kôq (laughs)!

144. E: Dhô pèsèq-pèsèq $k i$ piyé, yhô!

145. M: Ha iyho!

146. S: Mboh!
117. Nine thousand. Because it 1s, umm...

118. [About $S^{\prime}$ 's baby] Ma, she woke up!

119. You woke her up didn't you, Cecile! What are you doing waking her up anyway!

120. Hey! How come she came out (of her room)?

121. No. She (Cecile) went in there and woke her up!

122. How can that be?

123. You want to go pee-pee, Fifi, or not? Huh? You want to make pee-pee?

124. She hasn't been asleep an hour, but she already woke up!

125. OK. Come on, let's make pee-pee.

126. Uh-huh. Let's make pee-pee since you just woke up.

127. How about it? OK?

128. You're going to wet your bed!

129. Come on, tell me (if you want to).

130. Try to get her to go. Otherwise she' 11 wet her bed.

131. If you wet your bed...

132. Hey, don't make pee-pee on me!

133. Now. If you want to make pee-pee, tell me. Come on!

134. She's already got lots of hair, doesn't she?

135. It's like corn-silk.

136. She's got quite a bit.

137. It's like corn-silk, isn't it, when a baby of that age already nas so much hair.

138. Uh-huh .

139. She is really the ugliest.

140. I'd call that pretty!

141. You must be joking to call that pretty!

142. (Prettier than my) Fifi. [ $E^{\prime} s$ daughter is also called Fifi.]

143. She's got a flat nose like that (laughs).

144. How come our chlldren all have flat noses?

145. Well, what do you expect?

146. I don't know.

147. Of course! Why should they 
147. E: Ha 1yhô, irong kôq dô pès èq-pèsèq!

148. K: Ikiné a mèh ntèq, yhô!

149. H: Nèq metuné ketigô kurang banyu yha pèsèq-pèsèq, a .

150. K: Wés entèq iki Céq Wo.

151. S: Sil! Jangan maén-maén, Sil! Sam, iki 1ho, Fifi nangés!

152. M: Hayo, Fifi nurot! all have $f 1$ at noses?

148. Hey $1 t^{\prime} s$ almost run out [the cassette].

149. If they are born in the $d r y$ season and there is not enough water, their noses come out flat!

150. Hey, Uncle Wo, the tape has run out.

151. Cecile, stop playing with that! (To the maid) Sam, here! Fift is crying.

152. You be a good girl, Fifi. 


\section{Conversation 8. AT A PARTY}

A conversation recorded at a party given the night before a wedding in Semarang. The speakers are all Peranakan Chinese. They are: a college student (E), who made the recording, a photographer not otherwise known (F), and some elderly ladies ( $\mathrm{K}$ and $\mathrm{L}$ ), related to $\mathrm{E}$. Another brief participant is a middle-aged merchant (C) related to the family. As the conversation begins $E$ engages the photographer in small talk about what happens at the wedding.

1. E: Kembangé kan séng lakiq déwé yang mbawaq.

2. F: Ya, Ya.

3. E: Ya.

4. F: Tapi ambél dari sana, tô? Ambél darı sana? Sôkô nggôné wédôq, tô?

5. E: Daq, kembangé kan ...

6. F: Secara langsong dart sint kan mbawaq.

7. E: Jadi, nanti pada waktu temôn kan 1tu dikasiqké.

8. F: Ya, heqe. Ya, dari sini tô, yang mbawaq kembangé.

9. E: Kembangé itu yang mbikén sapa?

10. F: Apa? Yang mbikén itu?

11. E: Kembangé yang mbawaq yang dari 1akiq.

12. F: Ndaq, ndaq, yang mbikén dari mana?

13. E: Lho, tapi kembangé malemé sudah diserahké dari sini.

14. F: 0 , sudah serahké, tô?

15. E: Sudah.

16. F: Jadi pengapité tô ini? Kembang sana, tô?

17. E: Ndaq.

18. F: Ndaq, ndaq.

19. E: Jadi, kembangé itu ...

20. F: Apa?

21. C: Pôkôqé ônô bokèt.
1. It is the man himself who brings the flowers, isn't $1 t$ ?

2. Yes, yes .

3. Yes .

4. But they get them from there ( the bride's house), don't they? They get them from there. From the girl's place.

5. No. The flowers...

6. They bring them directly from here, don't they?

7. So, they give them at the point that the bride and the groom are brought together.

8. Yes. Uh-huh. They bring the flowers from here, don't they?

9. Who makes the flowers?

10. What? Who makes them?

11. The one who brings the flowers is from the husband's party.

12. No, no. That's not what I mean. The one who makes them is from...

13. Yes, but the flowers were already sent over from here the niont before.

14. Oh, they already sent them?

15. Yes.

16. So these are the bridesmaid's flowers. The flowers that are over there (are not the bride's but the bridesmaid's).

17. No.

18. No? No?

19. Those flowers...

20. What?

21. The bouquet is here, isn't it? From here they will bring it to the husband's place, and then from there they will turn 
22. E: Bokèté ada sini, tô? Nèq dah sini njoq dibawaq ke lakiq; tha nanti da sana dikasiqké séng prempuan.

23. F: Heqe, ya.

24. E: Séng prempuan séng pakéq itu.

25. E: Kô Po, taq kancani, yô?

26. K: Kaé, kaé, kaé! "Apa Kô barusan datang?" ngono sangkaqi Maq Ada. Kuwi nyonyah nganggo klambi ijo. Nganggo klambi ...

27. E: 0 , séng ... séng pakéq gelungan itu, pa?

28. K: Hôqô.

29. E: 0 , itu mog rumaé mukaq situ, kôq.

30. K: Ha iyhô.

31. E: Lha iyha. Kô Po gimana kôq ndaq lungô Yojô, wés suwi lho, yha?

32. K: Ndaq iya? Kowé agèq aku rônô ora ônô, kôq!

33. E: Dha mana, Kô?

34. K: Lha wông lé muni agèq ... agèq dikôngkôn karo, sôpô ... turés.

35. E: Hya $\quad .$. lagèq mubeng-mubeng. Nèq soq pagi dateng, ndaq?

36. K: Yhô, yhô. Nèq ndaq, kiraqé ndaq isa. Wông itu yhô, anu ... swak, kôq (laughs). Agèq, agèq.

37. E: Kôq swak gimana, tô?

38. K: Krah-krèh, wés tuwô, lah!

39. E: 0, hiya.

40. K: Opô kaé? Môntôré Kô Un, piyé?

41. E: O, môntôré Kô Un soq pagi. Jané tadi tô, mèh taq bawaq gi sini.

42. K: Yha.

43. E: Lha néng njog $\ldots$ nganu ...apa ... dipakéq da Amba rokmô.

44. $\mathrm{K}: \mathrm{Ya}$. it over to the girl.

23. Oh, yes.

24. It is the bride that is going to use them.

25. [E has left the photographer and takes a seat next to an elderly relative of his.] May I sit next to you, Aunt Po?

26. That one over there... umm... (she asked me) "Did you just come, Aunt?" That's what she said. She thought I was Ada. That lady that's wearing a green dress. With a dress...

27. Oh, you mean the one with a switch in her hair?

28. Uh-huh .

29. That lady's house is just across the street.

30. Yes, I know.

31. Of course. How come you havent't come to Yogya for a long time, Aunt Po?

32. What do you mean? I just was there, but you weren't around.

33. Where was that?

34. They told me that you were out on an assignment with... what's it called?... the tourists. [E was working as a guide.]

35. Oh yes. I was just going around. How about Uncle Eng Kang? Is he coming tomorrow morning, or not?

36. Yes. Yes. If he doesn't (show), probably he can't. The problem is he has been rather, umm... poorly (laughs). He's still...

37. He's been 111? What's the matter?

38. He's coughing--he's already old.

39. Oh, yes.

40. Is umm... how about Uncle Un's car?

41. Uncle Un's car will be brought here tomorrow. Actually, I was going to come in it...

42. Yes.

43. But then I thought that... 
45. E: Tor lagi, soq pagi itu ... ee ... kô Un mau dateng sendiri.

46. K: Yha .

47. E: Heqe, jadi nanti njoq ..., ngko njoq numpaq ôpô? Yha, a?

48. K: Heqe.

49. E: Tor lagi dipikér-pikér, nèq dibawaq sini malem ... nanti ... apa. Dadiné, ra nônô nggôné. Ndaq ada tempaté, tô?

50. K: Heqe.

51. E: Ndaq ada tempaté. Tor lagi ngko nèq $d i \quad .$. nganu bocah-bocah ngko, mbarèt-mbarèt gitu, yha.

52. K: Heqe, heqe.

53. E: Nanti nèq mbarèt-mbarèt, wa, malah éman-éman.

54. K: Heqe.

55. E: Mbồq yhô wés sésoq ésoq ja, mau mangkat ésuq-ésuq malaan, jam lima pagi.

56. K: Néng saqjané nèq supiré teros nunggôni, yhô ra wani.

57. E: Nha, yha nanti ... Tapi piyé yhô, lha wông soqalé Kô Un itu tanyaq gini, tô. Hô ... é tanyaq mbèq Iq Nyo déng, tanyaq mbèq Iq Nyo, nganu .... "Sapa ee ... Céq Péq iki sapa?" gitu, lho. Céq Péq.

58. K: 0 , Céq Péq.

59. E: "Céq Péq, yha ... yha ncéqé Mbun Hô, 1ho!" Lho, "Lha nèq, 1ha nèq mbèq Coan Liang?" "Ha ngkôé Nggiôq ..., Kôh Nggiôq Mbi."

60. K: 0 , yhô?

61. E: A, "Kudu tekô ikf!" haros datang, bilang gitu (laughs). umm, they would still be needing it at the Ambarrukmo Hotel.

44. Yes.

45. And further, tomorrow morning, Uncle Un is coming himself.

46. Yes.

47. Uh-huh. So then... (I was thinking) "What should I take?" you know what I mean.

48. Uh-huh .

49. And further, I thought about it, "If I bring it here in the evening, there isn't golng to be... So there isn't going to be any place to leave 1t." There won't be any place, isn't that so?

50. Uh-huh .

51. There won't be any place... Also if the children umm... scratch it all up, you know what I mean?

52. Uh-huh .

53. If the children scratch it, it would be a pity.

54. Uh-huh.

55. "So probably the best thing would have been just to go tomorrow morning." In fact I was going to leave real early, at five in the morning.

56. But actually if the driver is there all the time, they wouldn't dare.

57. Of course. That's so. But, umm, how shall I put it? The thing is Uncle Un asked me, umm... (i.e., Uncle Un himself wanted to come). I mean he asked Aunt Nyo, asked Aunt Nyo... umm... "Who is, umm, Mr. Pik [the bridegroom's father] ?" That's what he asked,.... Mr. Pik.

58. Oh, Mr. Pik.

59. "Mr. Pik is Mbun Ho's uncle." "So what is his relation to Coan Liang?" "He is the older brother, umm... younger brother of Giok, Giok Bi."

60. Oh yes? 
62. K: Heqe, heqe.

63. E: E ... 1ha nèq haros dateng, yha ...

64. C: Sudah tadi?

65. K: Yha.

66. E: Sini Céq Juéq.

67. K: Saqiki piyé, kerjô nang nd i?

68. C: Sapa?

69. E: Yha da sini.

70. K: $0 \ldots$ kwé séq dôdôl nèng pasar?

71. C: Saqini, yha ndaq lagi.

72. K: Nggaq lagi?

73. C: Wông sekarang ndaq payu, kôq.

74. K: Ki nèq ra kendel, yhô... yhô piyé? Yhô angèl lah.

75. C: Ha saqini semua yhô jalané nyl und op.

76. K: Yhô kudu kendel. Nèq ora wani sôbô pulisi, yhô ra bathi.

77. E: Ini, Maq!

78. L: Ndaq.

79. K: Lho, yha kôq njoq ... déq!

80. E: Heqe. Maq Lim jangan. Dhudoq sini, lho!

81. L: Yha, sudah. Taq dudoq sini.

82. E: Yha.

83. K: Pancèn kéné panggônané, yhô? Ngko, tô!

84. E: Yha .

85. K: Kowé kéné.

86. E: Sinf 1ho, Maq, Maq! Lha Kô Po? 0 ...

87. K: Piyé?

88. E: Ngambél karcis? Iq Hyang

89. K: Heqe.

90. E: Iq Nyo.

91. K: Nggiôq, yho.

92. E: Ini 1 ho, Maq.

93. L: A, sudah sini whaé. Péstané da sini, kôq.

94. K: 0! Arepé kéné! Kénéô!

95. L: Péstané da sini, kôq.

96. E: Yha. Si Maq njoq mbèq sapa, Maq, datengé?
61. "Umm, I'm going to have to go in that case." $\mathrm{He}$ has to come, he said (laughs).

62. Uh-huh. Uh-huh .

63. So if he is going to have to come, well (I couldn't borrow his car).

64. Have you eaten?

65. Yes.

66. Come over here Uncle Juik.

67. How is it going these days, where are you working?

68. Who?

69. He is still (working) here.

70. Oh... you are still selling in the market?

71. I have stopped now.

72. Oh you have?

73. Business is no good these days.

74. If you don't have a bit of courage... what can you do? It's rough.

75. Well, of course. Nowadays it has to be done through smuggling.

76. Well, you have got to be brave. If you don't dare hang around with the police, you aren't going to make any profit.

77. [inviting another woman to join them] Here, Grandma!

78. No!

79. Well, how come you don ${ }^{\prime} t . .$.

80. Sure. Grandma Lim, don't (sit over there). Come over here.

81. Oh, it's all right. I'll just sit here.

82. OK.

83. This was really her place before. Go on (get another chair).

84. OK.

85. You come here.

86. Come over here, Grandma. How about it, Aunt Po?... Umm...

87. What?

88. Did you get your ticket? Aunt Yang is coming tomorrow.

89. Uh-huh .

90. Aunt Nyo. 
97. L: Dhatengé mbèq Ciq Kim.

98. K: Oo. Naéq mobil tadi?

99. L: Yha naéq jip 1tu, 1ho.

100. E: Apa?

101. K: Kepriyé, s1 Yunyo, Nggiôq, Hyang?

102. E: Iq Hyang.

103. K: Kô Un?

104. E: Kô Un. Om Péng Hôk ndaq ngerti. Nèq ngkukôngé ndaq dateng - Ngkukôngé ndaq dateng. "Yhô wés kônô! Esoq nèq ... nèq mèh mangkat, yhô, sana ... nang kesana. Aku taq oraq ... taq tunggu omah."

105. K: Lha iyhô.

106. E: Aduh, tangané Hô sakét, Maq!

107. L: Lha iyha!

108. E: Titép dulu!

109. L: A.

110. E: Tangané Hô sakét kôq ini. Aduh!

111. K: Sakét kenôpô?

112. L: Jatoh.

113. E: Jatoh.

114. K: $0,0,0$ ! Wés jatoh nô ndi?

115. E: Da Bètesda.

116. K: Kapan?

117. E: Kemarèn. Lha ini naéq hônda, njoq nabraq anjéng.
91. And Giok.

92. Come over here, Grandma.

93. It's all right over here. The party is over here, as well!

94. Oh, you were going to sit here. Come on over here!

95. Oh, the party is over here.

96. Oh, yes. Who did you come with, Grandma?

97. I came with Mr. Kim.

98. Oh. Did you come in a car?

99. I came in that jeep.

100. What?

101. How about Yunyo, Giok, Yang?

102. Aunt Yang (is coming).

103. (How about) Ko Un?

104. Ko Un (is coming). I don't know about Uncle Peng Ho. HAs brother is not coming. "OK, go on over there. Tomorrow when you want to go, go ahead. I don't think I'11... I think I'11 stay and watch the house."

105. Of course.

106. Ouch, my hand hurts, Grandma!

107. We1l, what do you expect?

108. Hold this for a second.

109. Humph .

110. My hand is sore. Ouch.

111. How come it hurts?

112. He fell.

113. I fell.

114. Oh. You had a fall. Where?

115. Where the Bethesda is.

116. When?

117. Yesterdiy. I was driving my motorcycle and $I$ ran into a dog. 


\section{Conversation 9. FAMILY PLANNING}

A conversation among a group of middle-aged Peranakan Chinese ladies at a party. The tape recorder was set up near where they were sitting without their knowledge. They are not related, but they have known each other their whole lives.

1. S: Lha kôq apalagi, ini ... Ada lagi wông Semarang itu, ada ... Lha gèq patlikor wông dua.

2. W: Ndaq! Semarang 1tu?

3. S: Sembilan itu wé, lakiq kabèh; néng, nèq, nèq encimé daq kepéngén gitu. Tônggô saya dulu. Encéqé yang kepéngén. Ndiséq itu ciliqané Hwa-Hwa.

4. W: Ia. Misih inget ndèq ciliqané Hwa-Hwa itu seneng digéndông-géndông.

5. S: Dijaq dolan-dolan, yhō bocah itu teros.

6. L: Marai nèq dijaqi njoq macaqi apéq (laughs).

7. S: Tapi nèq ancimé, lé muni, "Aku kôq yhô oraq kepéngén. Wés, ora nduwé anaq wédôq, yhô wés. Soq mantuné wédôq-wédôq."

8. L: Wédôq kabèh.

9. W: Ra ndé anaq wédôq, yhô wés. Pôkôqé iku saqiki nang awaqé déwé. Nyambot gaé apéq, dadiné apéq.

10. S: Oraq, Pèq Yôq. Pèq Yôq, Kô Lé Ci. Teros Kô Lé Hwa. Teros kô Lé Hwa. Teros Nggiôq Jué.

11. W: Jèjèré sôpô?

12. S: Teros Loan. Lèq $I$. Teros Cwan Tyông. Tros Lèq Kim. Tros Lé Na. Bar Lé Kim, Lé $\mathrm{Na}$, tros Cwan Péq. Tros Cwan Lhiang, é ... Lé Kiauw séq déng!
1. And especially... There was another person from Semarang, there were twenty-four children from two (wives).

2. Really! In Semarang?

3. There were nine of them, but they were all boys. But the wife, she didn't want (to have any more). My neighbor formerly. It was her husband that wanted (more). That was formerly, when Hwa-Hwa was still little.

4. I still remember when Hwa-Hwa was little. She loved to have people carry her around.

5. Whenever I went out, I had to bring that child.

6. That's why you had to dress her up nicely, because you always brought her with you.

7. But the wife said, "I don't want any more. Never mind. If I don't have any girls, never mind. I'1l get daughters when the boys get married."

8. All girls.

9. If you don't have daughters, it doesn' $t$ matter. It all depends on ourselves, doesn't it? If you bring them up right, they will turn out right.

10. [Naming the children of a friend's family] No, it was Pik Yok. Pik Yok. After Pik Yok came Le Ci. Then Le Hwa. Then Le Hwa. Next came Giok Jue.

11. Who is next to him?

12. Then Loan. Lik I. Then Cwan Tiong. Then Lek Kim. Then Le $\mathrm{Na}$. After Le Kim came Le $\mathrm{Na}$, then Cwan Pik. Then Cwan 